\title{
TERMO DE COMPROMISSO EM PROCESSO ADMINISTRATIVO SANCIONADOR DA COMISSÃO DE VALORES MOBILIÁRIOS
}

Orientador: Professor DOUTOR José AlEXANDRE TAVARES GUERREIRO

Dissertação de Mestrado

Faculdade de Direito do Largo São Francisco

Universidade de São Paulo

São Paulo, 2013 
VINÍCIUS KRÜGER CHALUB FADANELLI

\title{
TERMO DE COMPROMISSO EM PROCESSO ADMINISTRATIVO SANCIONADOR DA COMISSÃO DE VALORES MOBILIÁRIOS
}

Orientador: Professor DOUTOR JosÉ ALEXANDRE TAVARES GUERREIRO

Dissertação de Mestrado

\begin{abstract}
Dissertação apresentada como requisito parcial para obtenção do título de Mestre em Direito Comercial pelo Programa de PósGraduação da Faculdade de Direito do Largo São Francisco.
\end{abstract}

Faculdade de Direito do Largo São Francisco

Universidade de São Paulo

São Paulo, 2013 


\section{RESUMO}

O estudo trata dos termos de compromisso, mecanismo de solução consensual aos processos administrativos sancionadores cuja utilização foi facultada à Comissão de Valores Mobiliários por inserção de norma legal específica na Lei 6.385/76, em 1997.

A parte inicial trata da natureza dessa ferramenta, relata os argumentos favoráveis e contrários à sua utilização no âmbito do mercado de valores mobiliários brasileiro; analisa a disciplina e as balizas legais aplicáveis, com referência ao processo legislativo e ao contexto regulatório em que foi criado; bem como examina as vantagens proporcionadas à administração pública e aos agentes do mercado pela celebração de tais acordos.

Segue-se uma segunda parte, na qual são apresentados os procedimentos pertinentes à adoção dos termos de compromisso, a interação entre a CVM e o Ministério Público Federal, a influência dos acordos sobre as entidades de autorregulação e a discussão a respeito da destinação dos valores arrecadados com os acordos substitutivos. Casos práticos (apreciados pela autarquia) e experiências estrangeiras (regras e impressões doutrinárias) são apresentados no decorrer do trabalho, quando pertinentes.

Palavras-chave: termo de compromisso; processo administrativo sancionador; regulação do mercado de valores mobiliários; acordo substitutivo. 


\begin{abstract}
This study addresses the settlement agreements ("termos de compromisso"), a consensual solution to administrative proceedings that may be used by the Brazilian Securities and Exchange Commission (“Comissão de Valores Mobiliários”) since the inclusion, in 1997, of a specific legal provision in Law 6,385/76.
\end{abstract}

The first part of this work deals with the nature of the aforementioned tool, reports the arguments for and against its use in the Brazilian securities market; analyzes the discipline and limitations set forth by applicable law, considering the legislative and regulatory context in which it was created; as well as examines the advantages provided by such agreements to the government and market agents.

A second part, which presents relevant procedures for the adoption of the settlement agreements, explains the interaction between the CVM and the Federal Prosecutors' Office ("Ministério Público Federal"), the influence of such agreements on self-regulatory organizations and discusses the allocation of amounts collected with the agreements. Case studies (analyzed by CVM) and foreign experiences (rules and impressions of scholars) are presented throughout the text, when relevant.

Keywords: administrative settlement; consent decree; punitive administrative proceedings; securities market regulation. 


\section{SUMÁRIO}

1. INTRODUÇÃO

1.1. CONSIDERAÇÕES INICIAIS

1.2. ESTRUTURA DO TRABALHO 10

PARTE I - EVOLUÇÃO HISTÓRICA, REGIME LEGAL, VANTAGENS E RESTRIÇÕES 13

2. PRÉ-HISTÓRIA DOS TERMOS DE COMPROMISSO 13

2.1. PARECER/CVM/SJU/N. $036-7$ DE JULHO DE 1980

2.2. PARECER/CVM/SJU/N. 097 - 13 DE SETEMBRO DE 1983

3. CONTEXTO REGULATÓRIO DA INTRODUÇÃO DOS TERMOS DE COMPROMISSO NO ORDENAMENTO JURÍDICO BRASILEIRO

3.1. MOTIVAÇÃO PARA A ADAPTAÇÃO DOS TERMOS DE COMPROMISSO À REALIDADE NACIONAL 22

3.2. ANTEPROJETO DE LEI ELABORADO PELA CVM 23

3.2.1. Termo de compromisso como alternativa de enforcement 24

4. INTRODUÇÃO DO TERMO DE COMPROMISSO NA LEI 6.385/76 PELA REFORMA DE 1997

(LEI 9.457/97)

4.1. NATUREZA DO TERMO DE COMPROMISSO 31

4.2. ANÁLISE DA POSSIBILIDADE JURÍDICA DA CELEBRAÇÃO DOS ACORDOS SUBSTITUTIVOS

4.2.1. Argumentos contrários à possibilidade de acordo entre a CVM e administrados 36

4.2.2. Argumentos favoráveis à possibilidade de acordo entre a CVM e administrados 39

4.3. OS REQUISITOS DO PARÁGRAFO 5 DO ARTIGO 11 DA LEI 6.385/76 47

4.3.1. Cessação da prática considerada ilícita 50

4.3.2. Correção de irregularidades e indenização de prejuízos 54

$\begin{array}{ll}\text { 4.4 INEXISTÊNCIA DO RECONHECIMENTO DE CULPA } & 61\end{array}$

4.5. INSPIRAÇÃO NO INSTITUTO ANÁLOGO DO DIREITO CONCORRENCIAL 64

4.5.1. Considerações sobre o Voto do Conselheiro do CADE Luis Fernando Schuartz (Requerimento n. 8700.004221/2007-56)

5. ALTERAÇÃO DA LEI 6.385/76 PELA REFORMA DE 2001- LEI 10.303/01 E DECRETO 3.995/01 
7. RESTRIÇÕES À ADOÇÃO DO ACORDO 97

7.1. ILÍ́CITOS RELACIONADOS À “LAVAGEM” DE BENS, DIREITOS OU VALORES 97

$\begin{array}{ll}\text { 7.2. PROJETO DE LEI 1.851/2011 } & 100\end{array}$

7.3. OUTROS CASOS PONTUAIS DE VEDAÇÃO LEGAL À CELEBRAÇÃO DE TERMO DE COMPROMISSO $\quad 103$

8. EFEITOS SOBRE A PRESCRIÇÃO 105

PARTE II - DISCIPLINA INFRALEGAL, PROCEDIMENTO E APLICAÇÃO 107

$\begin{array}{ll}\text { 9. DELIBERAÇÃ̃O CVM N. 390/01 } & 107\end{array}$

$\begin{array}{ll}\text { 9.1. REQUISITOS } & 108\end{array}$

$\begin{array}{ll}\text { 9.2. PROCEDIMENTO } & 108\end{array}$

9.2.1. Fases em que é possível apresentar a proposta 108

9.2.2. Conteúdo da proposta 117

9.2.2.1. Partes da proposta - exclusão de terceiros prejudicados $\quad 120$

9.2.3. Exame de legalidade pela Procuradoria Federal Especializada 124

9.2.4. Análise pelo Comitê de Termo de Compromisso 125

9.2.5. Decisão pela Diretoria Colegiada. Conveniência e Oportunidade 135

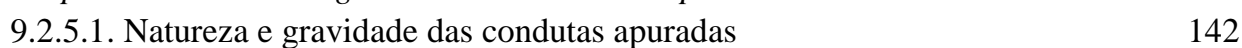

9.2.5.2. Antecedentes 144

9.2.5.3. Efetiva possibilidade de punição, no caso concreto 145

9.2.5.4. Irrecorribilidade da decisão 146

9.2.5.5. Causas de recusa pelo Colegiado $\quad 146$

9.2.6. Consequências da aceitação da proposta 148

9.2.7. Consequências da recusa da proposta 152

9.2.8. Publicidade do teor do acordo 153

9.2.9. Acompanhamento do cumprimento 153

9.2.10. Arquivamento: coisa julgada administrativa 155

9.2.11. Inadimplemento 156

9.2.11.1. Crime de desobediência (vigente até 2001) 156

$\begin{array}{ll}\text { 9.2.11.2. Exequibilidade } & 158\end{array}$

$\begin{array}{ll}9.2 .11 .3 \text {. Retomada do procedimento } & 158\end{array}$

10. DELIBERAÇÃO CVM N. 486/05 162

10.1. ALTERAÇÕES IMPLEMENTADAS 163

10.1.1. Instituição do Comitê de Termo de Compromisso 164

10.1.2. Composição do Comitê 165

10.1.3. Mecânica de funcionamento 165

10.1.2. Prazo para proposta 166 
12. TERMO DE COMPROMISSO E OS AGENTES DE AUTORREGULAÇÃO 168

12.1. INFLUÊNCIA DA CVM SOBRE A BM\&F-BOVESPA SUPERVISÃo DE MERCADOS 169

12.2. CELEBRAÇÃO DE CONVÊNIO ENTRE A CVM E A ANBIMA

13. TERMO DE COMPROMISSO E AJUSTAMENTO DE CONDUTA. ATUAÇÃO CONJUNTA DA CVM E MPF

13.1. AS TRÊS ESFERAS EM QUE HÁ REPERCUSSÃO DE INFRAÇÃO ÀS NORMAS DO MERCADO: PENAL, CIVIL E ADMINISTRATIVA

14. DESTINAÇÃO DOS RECURSOS ORIUNDOS DOS TERMOS DE COMPROMISSO

15. CONCLUSÃO

16. BIBLIOGRAFIA 


\section{INTRODUÇÃO}

\subsection{Considerações iniciais}

O tema do estudo adiante desenvolvido é o termo de compromisso celebrado entre a Comissão de Valores Mobiliários (“CVM" ou "Comissão") e agentes cuja atuação no mercado é por ela "disciplinada e fiscalizada", que tenham sido indiciados (ou $\operatorname{acusados}^{2}$ ) em razão de conduta potencialmente infratora às normas disciplinadoras do mercado de valores mobiliários ${ }^{3}$. Tal composição administrativa foi introduzida no ordenamento jurídico brasileiro pela Lei n. 9.457, de 5 de maio de 1997 (“Lei 9.457/97”) responsável, entre outros temas, por alterar o artigo 11 da Lei n. 6.385, de 7 de dezembro de 1976 ("Lei 6.385/76").

O objetivo do trabalho é a análise conceitual e da evolução do instituto, buscando relacioná-lo às tendências e registros históricos do mercado, norteadores da política regulatória; à postura dos agentes estatais; e aos reflexos no mercado de valores mobiliários.

Considerando a essencialidade da regulação do mercado de valores mobiliários para o seu desenvolvimento ${ }^{4}$, composta em parte pela fiscalização e, em parte, pela repressão às condutas danosas à higidez do mercado ${ }^{5}$, é também escopo do trabalho

\footnotetext{
${ }^{1}$ Qualquer referência, no presente texto, a "agentes atuantes no mercado" ou expressões similares deve ser entendido como os participantes do mercado de valores mobiliários praticantes das atividades indicadas no artigo $1^{\circ}$ da Lei 6.385/76, sujeitos à disciplina e fiscalização da Comissão de Valores Mobiliários nos termos dos artigos $8^{\circ}$ e $9^{\circ}$ da mesma lei.

${ }^{2}$ Considerando ser possível a celebração dos termos de compromisso tanto na fase em que o administrado é ainda tratado como indiciado ou investigado quanto na etapa da apuração administrativa, em que já é considerado e tratado como acusado, a utilização desses termos, exceto quando expressamente ressalvada, é indistinta.

${ }^{3}$ O presente trabalho adotará a expressão "mercado de valores mobiliários" como termo distinto de "mercado de capitais", embora autores importantes tomem um pelo outro. A esse respeito, vale destacar a advertência de Ariosvaldo Mattos Filho, extraída de transcrição de debate ocorrido em 5 de maio de 2009: "No Brasil, se usa mercado de capitais como sinônimo de mercado de valores mobiliários, quando não é. Se nós formos olhar a gênese, o mercado de capitais é onde o mercado financeiro e o mercado de valores mobiliários vão buscar recursos." (Cadernos Direito GV, Seminário 38, v. 7, n. 6, nov. 2010, p. 49). Adicionalmente fundamentam a distinção ora proposta GUERREIRO e LACERDA (1979, p. 31): "Evidentemente o mercado de capitais, no qual se insere o mercado de valores mobiliários, não resulta da ação do Estado nem é criação da lei." (sem grifos no original).

4 “[...] a intervenção do Poder Público, através dos instrumentos normativos apropriados, constitui inegavelmente condição necessária para a sobrevivência, o equilíbrio e o desenvolvimento do mercado." (GUERREIRO e LACERDA, pp. 31-32).

5 "Segundo a teoria clássica da regulação cabe às agências reguladoras corrigir falhas de mercado e não por outro motivo a CVM é uma autarquia federal, cuja atribuição é regular, fiscalizar e punir comportamentos que infrinjam as desejáveis práticas no mercado de valores mobiliários.” SZTAJN (2004, pp. 138-139). “A ação do Poder Público ora assume o aspecto didático e educativo, ora o de mera disciplina. Outras vezes, visa promover a segurança das relações individuais ou o desenvolvimento ou o saneamento da atividade econômica. Em muitos casos se contesta esse poder estatal. Mas todos estão de acordo em atribuir-lhe
} 
caracterizar o termo de compromisso como uma ferramenta à disposição da Comissão para o desempenho de suas funções como entidade autárquica reguladora, a partir de investigações sobre como essa ferramenta foi introduzida e os argumentos favoráveis e contrários à sua adoção.

O estudo descreve e avalia também os efeitos produzidos pela assinatura de um

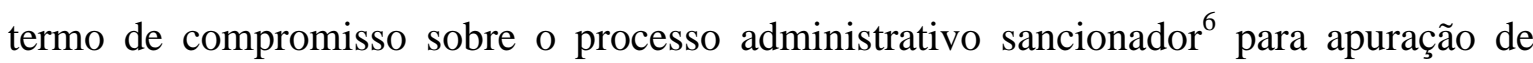
infrações conduzido pela $\mathrm{CVM}^{7}$, bem como o trâmite pelo qual é viável a obtenção de resultado considerado satisfatório por todos os envolvidos em tal procedimento (autoridade fiscalizadora e agente cuja conduta está sob análise), antes mesmo de sua apreciação pela Diretoria Colegiada da $\mathrm{CVM}^{8}$.

Com o cumprimento do pactuado no termo de compromisso, o acusado deixa de ser parte no procedimento administrativo sancionador sem que tenha sua culpa reconhecida. Para tanto, a conduta questionada pela CVM deve ser interrompida ${ }^{9}$, e os danos causados aos investidores e ao mercado acabam - ao menos sob a ótica da

desembaraçados poderes de ação, para o patrocínio da disciplina, da segurança e do saneamento do mercado" REQUIÃO (1975, p. 101).

${ }^{6}$ Questão terminológica relevante ao escopo do trabalho, amparada na referência de especialistas no tema: "No âmbito do mercado de capitais, a expressão 'processo administrativo sancionador', considerada em sentido lato, engloba tanto a fase meramente investigativa e inquisitorial, denominada inquérito administrativo, como a fase contraditória do procedimento, ou processo administrativo sancionador stricto sensu, considerada esta como instaurada a partir da intimação do acusado para apresentação da defesa $\left(\S 1^{\circ}\right.$ do art. $8^{\circ}$ da Deliberação CVM 538/2008)." WELLISCH e SANTOS (2010, p. 58).

${ }^{7}$ A competência para julgamento em primeira instância administrativa de atos ilegais praticados por participantes do mercado é estabelecida pelo artigo $9^{\circ}$, V, da Lei 6.385/76.

${ }^{8}$ Cabe à Diretoria Colegiada a análise de recursos apresentados contra decisões de superintendências da CVM ou de procedimentos ainda pendentes de qualquer decisão administrativa, a depender do rito pelo qual o processo administrativo sancionador seja conduzido. Sinteticamente: o rito sumário, adotado para apuração de infrações de natureza objetiva (enumeradas na Instrução CVM n. 251, de 14 de junho de 1996, conforme alterada - "I. CVM 251/96", desde que não seja caracterizado caso de reincidência específica), é disciplinado pela Resolução 1.657, de 26 de outubro de 1989, do Conselho Monetário Nacional ("CMN") e pela citada I. CVM 251/96, e se encerra com uma decisão da área técnica responsável por sua condução, da qual cabe recurso à Diretoria Colegiada. Já a averiguação das demais infrações ocorre pelo rito ordinário, regrado pela Resolução 454, de 16 de novembro de 1977, do CMN, e pela Deliberação CVM n. 538, de 5 de março de 2008 ("D. CVM 538/08"), e, após o período de instrução, conduzido em parte pela área técnica da CVM, é finalizada por julgamento pelo Colegiado da CVM. Tanto em um caso (recurso ao Colegiado, no rito sumário) quanto no outro (decisão "originária" do Colegiado, no rito ordinário), o administrado pode apresentar recurso ao Conselho de Recursos do Sistema Financeiro Nacional ("CRSFN"), órgão do Ministério da Fazenda que funciona como segunda instância administrativa (e, verdadeiramente, uma terceira instância, no caso de infrações apuradas seguindo o rito sumário). Para aprofundamento a respeito das funções e atividades do CRSFN, confira-se, entre outros, SADDI (2000) e VIEIRA (2000); e para pormenorizado relato a respeito do processo administrativo sancionador conduzido pela CVM, ritos e peculiaridades inclusive, cf. WELLISCH e SANTOS (2010).

${ }^{9}$ Quando aplicável. Especificamente no item 4.3.1 ("cessação da prática considerada ilícita") tal requisito será examinado, inclusive com análise das hipóteses nas quais é impossível de ser atendido. 
autoridade que aceitou as condições propostas - sendo ressarcidos, diretamente aos terceiros afetados ou mediante pagamento à própria $\mathrm{CVM}^{10}$.

O expediente sinteticamente descrito acima, cuja importância e utilização têm apresentado crescimento desde a sua inclusão no ordenamento do mercado de valores mobiliários brasileiro $^{11}$ (provavelmente na mesma cadência em que se desenvolve o referido mercado $^{12}$ ), é, em suma, o objeto deste estudo analítico e sistematizado, observadas as ressalvas e limitações metodológicas e de conteúdo oportunamente identificadas.

\subsection{Estrutura do trabalho}

O estudo, cujo escopo é o instrumento regrado pelos parágrafos $5^{\circ}$ a $8^{\circ}$ e 10 do artigo 11 da Lei 6.385/1976 (conforme redação atual), acaba por abranger necessariamente o conjunto estrutural no qual inserido, para identificação das funções desempenhadas pelo termo de compromisso em tal cenário. Adicionalmente, a sua contextualização é condição para um exercício analítico sistêmico, evitando-se as deficiências que poderiam decorrer de uma análise atomizada do tema.

Essencial informar desde já ser inevitável abordar alguns assuntos externos ao núcleo do tema, ainda que de forma instrumental. Naturalmente, inexiste pretensão de exaurir todos os temas referidos, o que seria impossível (e imprestável) considerando a abordagem pretendida. Cada um dos elementos (agentes de mercado, estrutura, objetivos e competência da CVM, infrações objeto de processos administrativos sancionadores e punições aplicáveis, por exemplo) será inserido dentro de uma lógica exclusivamente voltada para o foco da dissertação.

Estruturalmente, o texto está segmentado em quinze capítulos, compreendidos em duas partes. O presente capítulo, introdutório e justificativo, é dedicado à delimitação e indicação da relevância do tema e apresentação do trabalho e de sua estrutura.

A primeira parte tem início com o segundo capítulo, que traz as primeiras referências noticiadas sobre os termos de compromisso, em estágio ainda embrionário. $\mathrm{O}$

\footnotetext{
${ }^{10}$ Cuja destinação deveria, a nosso ver, ser revertido à preservação e desenvolvimento do mercado. O item 14 (“destinação dos recursos oriundos dos termos de compromisso") abordará o tema.

11 Termos de compromisso assinados por ano, de acordo com índice geral disponível em <www.cvm.gov.br>: 1998: 2 termos; 1999: 3 termos; 2000: 5 termos; 2001: 1 termo; 2002: 7 termos; 2003: 4 termos; 2004: 7 termos; 2005: 15 termos; 2006: 19 termos; 2007: 64 termos; 2008: 64 termos; 2009: 58 termos; 2010: 64 termos; 2011: 46 termos; 2012 (parcial até julho): 24 termos; totalizando 383 acordos.

12 É possível imaginar proporção entre um maior número de operações e acréscimo na fiscalização e identificação de infrações.
} 
terceiro capítulo, ainda tratando da parte histórica, apresenta o cenário regulatório em que tais acordos foram concebidos, e é seguido pelo quarto, que explica propriamente os termos de compromisso, seu conceito, sua introdução no ordenamento nacional (inclusive questionamentos feitos e manifestações de discordância, bem como o respectivo contraponto), e evidencia a inspiração em instrumento assemelhado adotado na tutela da concorrência. No quinto capítulo são relatadas as alterações promovidas na disciplina dos termos de compromisso pela reforma da Lei 6.385/76 ocorrida em 2001, sendo seguida, no sexto item, pela identificação da motivação para celebração de acordos e dos benefícios percebidos pelas partes signatárias (CVM e administrado). O sétimo ponto do trabalho aborda as situações em que há restrições à celebração de termos de compromisso, e o seguinte, último da primeira parte, cuida dos efeitos do termo de compromisso sobre a prescrição administrativa.

A segunda parte inicia com a análise da disciplina infralegal do tema, incluindo roteiro do procedimento aplicável à celebração dos termos (nono capítulo). Os dois capítulos seguintes tratam de mudanças ao normativo base, efetuadas por duas deliberações da CVM, posteriores. O décimo segundo capítulo aborda a influência das regras dos termos de compromisso sobre a disciplina da autorregulação, e o décimo terceiro trata da interação entre a Comissão de Valores Mobiliários e o Ministério Público Federal (“MPF”), abordando questão de destaque: a independência das diferentes esferas possíveis de responsabilização por atos dos agentes do mercado - administrativa, civil e penal.

O décimo quarto capítulo é dedicado à descrição da atual destinação dos valores pagos pelos compromitentes como condição para celebração dos acordos e à apresentação de sugestões para aproveitamento de tais recursos de maneira diversa, visando a fomentar o desenvolvimento do mercado.

Por fim, o décimo quinto capítulo objetiva arrematar o texto, consignando as considerações finais da dissertação.

Desde já cabe referência à ausência de um capítulo dedicado exclusivamente às realidades estrangeiras, de forma isolada, com referências doutrinárias e transcrição de normas, observando a preocupação de não pretender construir uma abordagem exaustiva de direito comparado ${ }^{13}$, pelos riscos de nunca ser suficientemente completa e fiel à realidade que se tenta retratar ${ }^{14}$. Referências a diplomas normativos e comentários de

\footnotetext{
${ }^{13}$ Conforme definido por Tullio Ascarelli em "Premissas ao Estudo do Direito Comparado", logo nas primeiras páginas de seus Problemas das Sociedades Anônimas e Direito Comparado.

14 “Como preliminar, é necessário reconhecer que o marco legal que disciplina as possibilidades de acordo está inserido em um ambiente institucinal que é distinto em cada país, com variações, entre outros, no
} 
estudiosos de alguns países são apresentadas, quando adequado, em contraposição ao endereçamento do tema no regramento brasileiro e, principalmente, identificando-se o que poderia ser tropicalizado para, de alguma forma, aprimorar a disciplina nacional vigente.

Também importa esclarecer a inexistência de um excerto dedicado exclusivamente aos casos práticos. Propostas de termos de compromisso, pareceres do Comitê de Termo de Compromisso, análises da Procuradoria Federal Especializada e decisões da Diretoria Colegiada são objeto de referência, sendo apresentados sempre que seu poder exemplificativo parecer útil.

funcionamento do sistema judiciário, nos custos e benefícios de se litigar, e na separação ou reunião das sanções penais e administrativas. Desse modo, as experiências de outras jurisdições devem sempre ser analisadas, levando-se em consideração tais diferenças, as quais, via de regra, impedem a mera emulação das práticas internacionais para a jurisdição brasileira."

Advertência contida no Voto do Conselheiro Paulo Furquim de Azevedo, relator do Requerimento 8700.004992/2007-43, no contexto do Processo Administrativo 08012.011142/2006-79, conduzido pelo Conselho Administrativo de Defesa Econômica - CADE, pp. 6-7. Apesar de oriundo do contexto de defesa da concorrência, o aviso é perfeitamente cabível aos termos de compromisso celebrados no contexto do mercado de valores mobiliários. 


\section{PARTE I - EVOLUÇÃO HISTÓRICA, REGIME LEGAL, VANTAGENS E RESTRIÇÕES}

\section{PRÉ-HISTÓRIA DOS TERMOS DE COMPROMISSO}

A possibilidade de celebração de termo de compromisso entre a autarquia fiscalizadora das atividades do mercado de valores mobiliários - a CVM - e os fiscalizados foi positivada no ordenamento nacional com a Lei 9.457/97, que adicionou previsão a respeito do termo de compromisso à Lei 6.385/76. Antes do referido diploma, porém, há diversas referências a esse instrumento, as quais serão em seguida tratadas.

Já em pareceres da Superintendência Jurídica da CVM, especificamente nos identificados sob os números 36, de 1980 (Parecer/CVM/SJU/nº 036 - 07.07.80), e 97, de 1983 (Parecer/CVM/SJU/n 097 - 13.09.83) ${ }^{15}$, é possível identificar clara referência e inclusive detalhamento sobre a função e utilidade do termo de compromisso.

Tais documentos abordaram a possibilidade de adaptação de institutos estrangeiros análogos - destacadamente os acordos feitos pela U.S. Securities and Exchange Commission ("SEC") ${ }^{16}$ - e trataram da avaliação da possibilidade de a CVM firmar acordos com particulares. À época, o corpo jurídico da Comissão antecipou potenciais pontos positivos com eventuais acordos. Porém, acertadamente, rechaçou a celebração de acordos com administrados, fundamentalmente em razão da falta de previsão legal, somada à obrigatoriedade de a administração pública pautar sua atuação pela estrita legalidade $^{17}$. Concluiu o órgão jurídico da própria CVM, então, ser a previsão legal pressuposto para a existência dos termos de compromisso ${ }^{18}$.

Nos itens subsequentes serão abordadas as especificidades de cada um dos pareceres, considerando as dúvidas apresentadas à consultoria jurídica interna da CVM e os casos originadores de cada uma das consultas.

\footnotetext{
15 Disponíveis para consulta em 〈www.cvm.gov.br/port/redir.asp?subpage=parecerato $>$ e <www.cvm.gov.br/port/public/pareceres.asp > . Acesso em 10mar2011.

${ }^{16}$ Para histórico a respeito do desenvolvimento da regulação do mercado nos Estados Unidos previamente à criação da US Securities and Exchange Commission, inclusive os debates a respeito do modelo a ser adotado (exclusivamente repressivo ou o sistema de registro prévio à oferta de valores mobiliários ao mercado) cf. PEDREIRA e LAMY FILHO (2009, pp. 137-138).

17 "O regulador deve se precaver para, conforme ensinamento de San Tiago Dantas, não tomar poderes que não lhe foram confiados, nem estender sua autoridade além do campo marcado pela legalidade." CANTIDIANO (2005) citando discurso de despedida proferido por Luiz Antonio Sampaio Campos, ao deixar a CVM.

${ }^{18}$ No intervalo entre o primeiro e o último dos pareceres ora referidos, a CVM elaborou um anteprojeto para reforma da Lei 6.385/76, visando (entre outros muitos temas) suprir a ausência de previsão legislativa então identificada, nos termos do relatado no item 3.2.
} 


\subsection{Parecer/CVM/SJU/n. 036 - 7 de julho de 1980}

Em 1979, portanto poucos anos após a criação da própria CVM, a Superintendência de Relações com Empresas da CVM (“SEP”) formulou consulta à Superintendência Jurídica da mesma autarquia ("SJU”), registrada no Memo/CVM/SEP/n 045/79, respondido pelo parecer ora em comento ${ }^{19}$, indagando a respeito da possibilidade de adoção de expediente - supostamente existente - para regularização de "emissões públicas marginais, através da concessão de um registro posterior ao lançamento dessa mesma emissão ao público" ${ }^{20}$, pelo qual "o BACEN desistiria de qualquer ação contra os agentes envolvidos, sugerindo, de tal forma que a regularização de tais emissões implicaria a adoção do consent decree",21.

A consulta e o parecer oferecido em resposta, há mais de 30 anos, trazem a primeira referência que se tem notícia a respeito da discussão em torno da possibilidade de se aplicar o consent decree $e^{22}$ na fiscalização do mercado de valores mobiliários brasileiro $^{23}$. Trata-se de evidência inequívoca de que o tema não é exatamente recente, embora extremamente atual.

A própria superintendência consulente apresentou à SJU informações a respeito de suposto procedimento adotado pelo Banco Central do Brasil ("BCB") ${ }^{24}$, pelo

\footnotetext{
${ }^{19}$ Consulta e parecer disponíveis em < www.cvm.gov.br $>$, acesso em 10mar2011.

${ }^{20}$ Conforme o item "Consulta" do parecer.

${ }^{21}$ Conforme o item "Consulta" do parecer.

$22 \mathrm{O}$ consent decree, figura típica do direito inglês, teve seus grandes traços reproduzido pelo ordenamento jurídico americano. Pode ser sintetizado como "pronunciamento do tribunal, ou da agência administrativa com poderes quase-judiciais, após um plea of guilty ou um plea of nolo contendere de parte do acusado, no qual o mesmo reconhece, de uma forma ou de outra, a procedência da pretensão punitiva manifestada contra ele". (ARAGÃO E SANTOS, 1979, p. 1.) "Nos Estados Unidos, o consent decree constitui acordo feito no âmbito do Poder Judiciário, entre a SEC e o réu, no sentido de que este cesse as atividades consideradas ilegais pelo Governo". (Parecer/CVM/SJU/93/83)

23 À época, a expressão termo de compromisso não era utilizada no contexto do mercado de valores mobiliários para significar acordo entre CVM e um ou mais de seus administrados, objetivando o encerramento de procedimento administrativo sancionador. "Termo de compromisso" era um dos documentos de apresentação obrigatória pelos auditores independentes para a obtenção de registro perante a CVM, conforme disciplinado pela Instrução CVM n. 4, de 24 de outubro de 1978 ("I. CVM 4/78"). Firmando tal documento, os auditores comprometiam-se a observar as regras aplicáveis à sua atividade, manter dados cadastrais atualizados e fornecer às autoridades, anualmente, a relação de clientes participantes do mercado de valores mobiliários. A denominação de tal documento não foi mantida pela Instrução CVM n. 204, de 7 de dezembro de 1993 (norma revogadora da I. CVM 4/78), o qual passou a ser chamado, incorporando uma série de adaptações e alterações, de "declaração legal".

24 Importante referir que, anteriormente à criação da CVM, o BCB era a autoridade incumbida da responsabilidade pelo mercado de valores mobiliários no país - especificamente por sua Gerência do Mercado de Capitais - GEMEC -, já constante da estrutura original do BCB, conforme criada pelo CMN em 1965; e pela Inspetoria do Mercado de Capitais - ISMEC, criada em 1967 e que absorveu as funções de fiscalização referentes ao sistema não-bancário, conforme referem NOVELLI (2001, pp. 77-81), e WALD (2002, p. 7). "“...] na estrutura do Banco Central, com a pletora de suas atribuições, o setor encarregado do mercado de valores mobiliários não poderia ter a independência e o status na administração federal indispensáveis para o policiamento eficiente do mercado de valores mobiliários" (PEDREIRA e LAMY
} 
qual seria possível a concessão de um registro ulterior à emissão, dotado do poder de regularizar emissões de valores mobiliários não registradas tempestivamente. A concessão de tal registro seria precedida por requisição e análise de informações e também pela aplicação das penas previstas na regulamentação vigente sobre o tema, em razão da inobservância das regras aplicáveis pela conduta anterior. Após a conclusão de tal procedimento, ainda de acordo com a SEP, o BCB não empreenderia ações punitivas em face dos agentes envolvidos, omissão que poderia ser interpretada como a utilização do mecanismo de consent decree. Indagou, por fim, a mesma SEP, se "ao abrir mão de penalizar, a autoridade poderia estar afetando interesses de terceiros" ${ }^{\prime 25}$.

A SJU, ouvido o BCB, concluiu inexistir o procedimento organizado referido pela SEP, supostamente composto por (i) obtenção de informações e (ii) dispensa na apuração das condutas e apenação dos envolvidos, em decorrência da regularização tardia das ações e atividades do administrado. Ao contrário: observou a SJU que a adequação das emissões aos requisitos e a apuração de responsabilidade em razão de condutas à margem das regras postas eram coordenadas por departamentos diversos do BCB e que falhas na punição decorriam essencialmente da falta de material humano para conduzir as investigações e coordenar a apenação dos infratores envolvidos. Seguramente, anotou o

FILHO, 2009, pp. 141-142). Também tratando da necessidade de uma regulação do mercado independente da então oferecida pelo $\mathrm{BCB}$, vale reproduzir trecho relevante do parecer apresentado pelo então Deputado Federal Luis Viana Neto, quando do trâmite do projeto que originou a Lei 6.385/76 no Congresso Nacional: "Sobrecarregado de funções outras, sem dúvida mais relevantes e precípuas de um Banco Central, tais como gestor da moeda, do crédito, do balanço de pagamentos e da dívida pública, o Banco Central do Brasil não pôde dedicar à administração do mercado de capitais a atenção prioritária e especializada que se impunha. Ninguém ignora os revezes sofridos pelo incipiente mercado de capitais brasileiro em virtude da inexistência de um órgão cuja função primeira fosse o seu policiamento. Aliás, já assinalado que, à sobrecarga de funções, dois outros fatores teriam contribuído para o malogro do Banco Central no cumprimento de suas funções de fiscal do mercado de valores mobiliários. Primeiro, a submissão do mercado de capitais ao mesmo estilo de administração burocratizada que tradicionalmente vem sendo adotado, com sucesso, na fiscalização bancária, ignorando que, num mercado instável e sujeito a distorções e abusos como o de capitais, 'a administração é mais complexa, e sobretudo exige maior presença e rapidez de decisão'. Segundo, o comportamento distante e reticente, ajustado aos mercados apoiados em grandes estruturas burocráticas, como os bancos comerciais, mas inadaptado a mercados com estruturas atomizadas que funcionam como leilões públicos ou mediante ofertas públicas, como é o caso do mercado de capitais." (Parecer transcrito integralmente em LIMA, 1977, $2^{\circ}$ vol., pp. 197-203. O trecho referido está registrado nas pp. 200 e 201). No mesmo sentido, porém de forma mais assertiva, afirmou REQUIÃO (1975, p. 101): “Atribuiu-se essa magna função, [regulação do mercado] entre outras, ao Banco Central do Brasil, o que constituiu um grave erro. [...] A ineficiência do Banco Central do Brasil nesse setor, como órgão regulador e disciplinador, foi clamorosa. Sua impassividade e incompreensão para o drama nacional que então se desenrolou permitiam e estimularam [...] pilhagem da poupança de milhões de brasileiros inermes [...]". Foge do objeto do presente trabalho o panorama histórico geral da regulação do mercado de capitais e de seu segmento de valores mobiliários, que já foi abordado de forma ampla por diversos autores, entre os quais LEÃES (2004, especificamente o item 2 - pp. 1426 e ss), PEDREIRA e LAMY FILHO (2009, pp. 140-142), WALD (1999, pp. 5-7), ROCHA (2000, pp. 70-76), COSTA (2000), ALVARENGA, (1997, especificamente nas pp. 147-148, em que a autora inclusive refere ao descontentamento do BCB e oposição deste com a nova organização, pois "não aceitava a perda de parte de suas atribuições para a CVM").

${ }^{25}$ Conforme o item "Consulta" do parecer ora referido. 
corpo jurídico da CVM, não havia consent decree no âmbito do $\mathrm{BCB}$, enquanto era essa a autoridade responsável pelo registro das emissões de valores mobiliários pelos agentes atuantes no mercado ${ }^{26}$.

Conclui, então, tal item do parecer da SJU (a cuja análise ora elaborada é limitada, por ser o excerto do documento relacionado ao objeto do presente trabalho) explicando que, na situação apresentada, não seria necessário ou mesmo recomendável a adoção de consent decree, pois seria plenamente possível a punição à conduta e a regularização da situação do emissor, com a obtenção de um novo registro. Para a SJU, "a regularização só importaria em adoção do consent decree no caso de se abandonar a ideia de penalização, o que não nos parece necessário, e, salvo melhor juízo, nem mesmo viável, haja vista que a CVM não pode abrir mão do seu poder disciplinar"27.

Interessante notar que o conceito de consent decree adotado no parecer diferia consideravelmente do conceito do termo de compromisso atual ${ }^{28}$. Compartilhando a ideia da SEP, ao retratar o que pensava tal superintendência ocorrer no âmbito do BCB, e influenciada pela já abordada visão americana sobre o tema, a SJU adotou como premissa que eventual consent decree dependeria da concordância do infrator sob investigação com a aplicação de pena prevista no ordenamento, o que teria efeitos análogos a uma confissão quanto à conduta: "ainda que adotado o consent decree, os direitos de terceiros não viriam a ser lesados. Ao contrário, uma vez que o infrator reconhecesse, junto à CVM, o fato delituoso, sua confissão seria até útil ao investidor prejudicado, que nela embasaria ação civil, se lhe conviesse" 29 .

\footnotetext{
${ }^{26}$ Conforme o item II (denominado "Atuação do BACEN") do parecer: "Quanto aos procedimentos mencionados pela SEP, quais sejam, levantamento de dados, recebimento das informações, instauração de inquérito, etc., não seguiam, necessariamente, a ordem em que aparecem na consulta, mesmo porque tais atividades eram comandadas por divisões distintas do BACEN, muitas vezes realizando-se paralelamente, cada qual a critério de determinada área. Em tese, portanto, havia, ou deveria haver, ao término dos inquéritos, penalização. Se é fato que isso nem sempre ocorria, talvez a explicação resida no acúmulo de serviço, não sendo possível a tramitação de todos os processos iniciados ou por iniciar. Igualmente desconhecia-se qualquer consideração em torno do consent decree, e não temos conhecimento de como o DEMEC atuava, no sentido da regularização do registro. Quer-nos parecer que os inquéritos, conduzidos pelo DEFIM, muitas vezes se interrompessem, por dificuldades operacionais, enquanto que a regularização caminhasse, isolada, comandada pelo DEMEC".

${ }^{27}$ Conforme o item III do parecer, denominado "A regularização de emissões e o consent decree".

${ }^{28}$ Conforme os itens 4.3 e 4.4 do presente trabalho. Tal ideia também fora refletida na versão original do projeto de lei que cuidou da introdução do termo de compromisso no contexto do mercado de valores mobiliários brasileiro, conforme veremos nos itens citados, e que foi suprimida, quando de sua redação final, aprovada na Câmara dos Deputados.

${ }^{29}$ Conforme o item V do parecer, denominado "Direitos de terceiros".
} 


\subsection{Parecer/CVM/SJU/n. 097 - 13 de setembro de 1983}

Em 1983 a Diretoria Colegiada apresentou nova consulta, endereçada desta vez à Gerência de Legislação e Pesquisa da Superintendência Jurídica ${ }^{30}$. Questionava, nesta ocasião, a respeito da "possibilidade de a CVM não instaurar inquérito administrativo contra o infrator das normas que lhe incumbe fiscalizar", caso atendidos alguns requisitos pré-determinados, a saber: (i) o reconhecimento da prática do ilícito, (ii) a indenização dos prejuízos causados e (iii) o comprometimento com a não reincidência da conduta ${ }^{31}$.

A adoção de tal procedimento poderia encontrar fundamento, segundo embasamento sugerido na própria consulta, nas finalidades da CVM, estabelecidas na Lei 6.385/76 (responsável pela constituição da autarquia), especificamente na previsão dos incisos de seu artigo $4^{\mathrm{o}}$ : promoção da expansão e funcionamento eficiente e regular do mercado (inciso II), proteção dos investidores contra emissões irregulares, atos ilegais de controladores e administradores de companhias ou de carteiras de valores mobiliários (inciso IV), prevenção e repressão a fraudes e manipulações de demanda, oferta ou preço de valores mobiliários negociados (inciso V) e asseguração do respeito às praticas estritamente equitativas no mercado (inciso VII) ${ }^{32}$. E, também, na regra do artigo $5^{\circ}$ da então denominada Lei de Introdução ao Código Civil ${ }^{33}$ : "Na aplicação da lei, o juiz atenderá aos fins sociais a que ela se dirige e às exigências do bem comum”.

Destacava-se ainda, na consulta, que o objetivo seria não a aplicação das penalidades referidas na legislação, mas sim "sancionar o infrator por outros meios", e

\footnotetext{
30 As funções anteriormente desempenhadas pela Superintendência Jurídica foram absorvidas pela Procuradoria Federal Especializada, conforme referido, exemplificativamente, na declaração de voto apresentada pelo Diretor Eli Loria no Processo n. RJ 2009/5863, em 28 de julho de 2009 (disponível em <www.cvm.gov.br/port/descol/respdecis.asp?File=6603-0.HTM $>$, acesso em 10mar2011).

${ }^{31}$ Conforme o item "Consulta" do parecer.

32 Redação vigente à época, anterior à reforma operada pela Lei n. 10.303, de 31 de outubro de 2001, que incluiu alínea "c" ao inciso IV, tratando de proteção contra insider trading: "Art. $4^{\circ} \mathrm{O}$ Conselho Monetário Nacional e a Comissão de Valores Mobiliários exercerão as atribuições previstas na lei para o fim de: [...] II promover a expansão e o funcionamento eficiente e regular do mercado de ações, e estimular as aplicações permanentes em ações do capital social de companhias abertas sob controle de capitais privados nacionais; [...] IV - proteger os titulares de valores mobiliários e os investidores do mercado contra: a) emissões irregulares de valores mobiliários; b) atos ilegais de administradores e acionistas controladores das companhias abertas, ou de administradores de carteira de valores mobiliários. V - evitar ou coibir modalidades de fraude ou manipulação destinadas a criar condições artificiais de demanda, oferta ou preço dos valores mobiliários negociados no mercado; [...] VII - assegurar a observância de práticas comerciais equitativas no mercado de valores mobiliários".

${ }^{33}$ Decreto-Lei n. 4.657, de 4 de setembro de 1942, cuja ementa foi alterada pela Lei n. 12.376, de 30 de dezembro de 2010, e passou a ser a "Lei de Introdução às normas do Direito Brasileiro".
} 
indagava, também, se eventual acordo poderia ser efetuado a qualquer instante ou somente após a instauração do inquérito administrativo ${ }^{34}$.

O parecer traça de forma sintética a lógica do consent decree, apresentando-o como instrumento inspirado em ferramentas desenvolvidas originariamente por países de herança do direito consuetudinário. Segue com explicação sobre o funcionamento e dinâmica aplicáveis, inclusive destacando (i) tratar-se de acordo celebrado no âmbito judicial (e não no cenário administrativo), (ii) a inexistência de assunção de culpa pelo signatário do acordo e (iii) a natureza dos compromissos que podem ser assumidos (exemplificando com a hipótese de devolução de lucros obtidos em decorrência de prática de infração).

Quanto ao tema central, a análise da possibilidade de a CVM celebrar acordos com particulares, é - a exemplo do parecer de 1980 citado anteriormente - amparada na vinculação estrita dos atos administrativos praticados por essa autarquia aos comandos legais. Observando o quadro legislativo da época, o parecer conclui no sentido de que "a CVM não possui competência legal para adotar esse sistema adaptado do direito anglosaxão" e, mesmo reconhecendo os potenciais benefícios da utilização da ferramenta, resta “indispensável, portanto, que a legislação confira tal poder ao administrador”.

É afirmado, ainda, no parecer, considerando o arcabouço normativo então vigente, que "a CVM não está legalmente autorizada a proceder a acordos, como substitutivo de medidas que lhe impõe a lei adotar".

Analisando o teor do documento, parece claro que, pelo menos desde $1983^{35}$, já interessava à CVM contar com o termo de compromisso como mecanismo alternativo ao julgamento administrativo, na condução dos casos apreciados pela autarquia. O óbice a tal plano era a vinculação aos limites de atuação impostos pela legislação que, por ser omissa quanto ao tema, impedia qualquer iniciativa ${ }^{36}$.

\footnotetext{
34 A possibilidade de celebração de termo de compromisso antes, durante e depois da fase de inquérito constitui-se em um dos pontos em que inexiste consenso. Existem, como veremos no item 9.2.1, posições contraditórias em relação à eficiência a ser alcançada com a celebração nos diferentes momentos. Atualmente a questão é regulada pela Deliberação CVM n. 657, de 7 de fevereiro de 2011, abordada no referido item e também no item 11 abaixo, que, como veremos, permite a proposição e assinatura de termos de compromisso a qualquer momento, inclusive antes da existência de processo administrativo sancionador em curso.

${ }^{35}$ Foram identificadas outras oportunidades posteriores (naturalmente anteriores a 1997), nas quais a SJU fez referência à impossibilidade de adoção dos termos de compromisso: pareceres CVM/SJU/027/08.11.88 e CVM/SJU/021/26.05.89.

${ }^{36}$ Um trecho do Parecer/CVM/SJU/n. 097 de 1983 sintetiza o posicionamento adotado: “[...] a adoção do consent decree, pela CVM, nos termos propostos na consulta, carece de prévia e expressa autorização legal”. Superado tal entrave, pela inserção de previsão expressa na Lei 6.385/76, o termo de compromisso foi finalmente incorporado ao rol de ferramentas à disposição da CVM para desempenho de seu papel.
} 


\section{CONTEXTO REGULATÓRIO DA INTRODUÇÃO DOS TERMOS DE COMPROMISSO NO ORDENAMENTO JURÍDICO BRASILEIRO}

Para que a CVM pudesse alcançar seus objetivos - relacionados no artigo $4^{\circ}$ da Lei $6.385 / 76^{37}$ - a ela foram atribuídos, pela legislação que a criou, poderes para regular o mercado de valores mobiliários ${ }^{38}$. A finalidade da Comissão ${ }^{39}$ está descrita nos itens do artigo citado, e serve de fundamento para a sua interferência no mercado ${ }^{40}$, direcionando comportamentos, limitando a liberdade de ação e iniciativa dos participantes, bem como estabelecendo a punição dos infratores às regras existentes, tudo com o fim de minimizar os efeitos das medidas adotadas livremente pelos agentes econômicos ${ }^{41}$.

A atividade regulatória - pautada na tutela do mercado de valores mobiliários ${ }^{42}$ e especificada no artigo $8^{\circ}$ da Lei 6.385/76 - é gênero, do qual a regulamentação (prevista no inciso I) parece ser uma das espécies ${ }^{43}$, ao lado da fiscalização e da inspeção (abordadas nos incisos III e V), do trato dos registros necessários para a garantia de igualdade de informações entre os participantes do mercado (tema do inciso II), e da divulgação das informações relacionadas ao mercado e seus agentes (prevista na segunda parte do inciso

\footnotetext{
${ }^{37}$ PEDREIRA e LAMY FILHO (2009, p. 142) inclusive identificam e dividem os objetivos da regulação, enumerados no artigo $4^{\circ}$ da Lei 6.385/76, entre (a) aqueles que visam resguardar o desenvolvimento do mercado e, por consequência, da economia nacional; e (b) os itens constantes do escopo da CVM que objetivam preservar e incrementar o interesse dos investidores no mercado de valores mobiliários.

${ }^{38}$ A experiência indica que é sólida a hipótese de que o mercado de valores mobiliários, em diversos locais do globo e em diferentes momentos históricos, depende da atuação e do desempenho de um ente na atividade de estipular regras e vigiar seu respectivo cumprimento. Anota-se que na Inglaterra de 1697 ocorreu uma das primeiras tentativas de regulamentar a atuação no mercado de bolsa, quando problemas surgiram da atuação de corretores não licenciados para realizar a atividade ali desenvolvida. Como solução, o "London's Common Council ordered that 'the Names and Surnames of all such Persons who are and shall be duly admited and sworn Brokers as aforesaid, be speedily Printed or fairly Written in a Table, and published by being hung up at the Entrance of the Royal Exchange"'. GLAISYER (2006 p. 41).

${ }^{39}$ GUERREIRO (1981, pp. 66-67) assim elucida dita finalidade: “[...] impõe-se reparar que os valores encampados pelo legislador de 1976 se acham discriminados, explicitamente, pelo art. $4^{\circ}$ da Lei 6.385/76. Nessa enumeração programática e valorativa, encontram-se os fins justificadores do poder disciplinar da CVM, por consubstanciarem os próprios objetivos da autarquia".

40 "Na verdade, todas as decisões (na área regulatória e no exercício da função fiscalizadora) que devem ser adotadas pelos funcionários da CVM, desde os seus técnicos, e até os seus dirigentes, têm por objetivo final proporcionar ao mercado regras de funcionamento melhores e mais equiitativas, o que possibilita, indubitavelmente, o desenvolvimento do mercado. Num segmento da atividade econômica em que o poder público cumpre adequadamente as suas funções de agente regulador e fiscalizador da atuação dos particulares, é inegável que resulte um aperfeiçoamento das práticas daqueles que se utilizam do mercado, o que the proporciona maior credibilidade e confiabilidade e, por conseguinte, uma possibilidade real de expansão crescente". CANTIDIANO (1999, p. 27).

${ }^{41}$ Sobre o tema, basilar a referência a COMPARATO (1978).

42 " [...] o fim último que justifica o poder disciplinar da CVM é a tutela do mercado de valores mobiliários. [...] entende-se por tutela do mercado de valores mobiliários, nesse contexto, o conjunto de atribuições que competem à CVM, nos termos dos arts. $8^{\circ}$ e $9^{\circ}$, cujo conteúdo e alcance deve ser interpretado em estrita consonância com os objetivos programáticos da Comissão, tais como discriminados no art. $4^{\circ}$ da Lei 6.385/76". GUERREIRO (1981, p. 68).

43 “Assim, a expressão regulação engloba atividades estatais que vão da criação de normas, passando pela sua implementação por meio de determinados atos administrativos e pela fiscalização de seu cumprimento, até a punição dos infratores". YAZBEK (2009, p. 184).
} 
III). Vale a reprodução de excerto de parecer do Professor LEÃES (2004, p. 1.427), explicando a atividade regulatória:

\begin{abstract}
“[...] tendo por objeto a limitação e o condicionamento de atividades particulares, com a finalidade de adequá-las ao interesse coletivo, o poder de polícia se exterioriza através da regulamentação, controle e contenção dessas atividades. Daí por que podemos dizer que o poder de polícia importa em tríplice função: a) a faculdade normativa, regulando a matéria de sua competência, regulamentando a lei ou a suprindo com normas conjunturais; b) a atividade fiscalizadora, através da qual a Administração controla a atividade policiada, procurando antecipar-se às perturbações do interesse público, com atuação preventiva e suasória; e c) a atuação sancionatória, mediante procedimentos punitivos, com a aplicação de sanções administrativas destinadas a compelir remissos e infratores ao cumprimento dos preceitos disciplinadores das atividades supervisionadas". (destaques no original)
\end{abstract}

Importante ao menos referir discussão a respeito da titularidade do poder de regulamentação, ou da faculdade normativa, conforme terminologia proposta pelo autor acima referido, a qual seria, nos termos dos artigos 84, IV, e 87, II, da Constituição da República Federativa do Brasil, de 5 de outubro de 1988 (“CF/88”), de competência exclusiva do Poder Executivo. Ainda que estruturalmente a Comissão de Valores Mobiliários esteja vinculada ao Ministério da Fazenda, inexiste, em relação a tal Ministério, subordinação hierárquica (conforme disciplina o $\operatorname{artigo} 5^{\circ}$ da Lei 6.385/76), configurando-se, portanto, como autarquia especial. Apesar de ter encontrado resistência, atualmente $^{44}$ parece ser amplamente predominante a corrente entendedora de que tais entidades, legalmente, "atuam como se fossem poderes legiferantes ou como se fossem órgãos judicantes" $" 4546$.

Há outro dispositivo constitucional - o artigo 174 ("Como agente normativo e regulador da atividade econômica, o Estado exercerá, na forma da lei, as funções de fiscalização, incentivo e planejamento, sendo este determinante para o setor público e indicativo para o setor privado.") - que serve de fundamento para o poder normativo da Comissão $^{47}$.

\footnotetext{
44 “[...] entende-se ultrapassada a concepção tradicional de que a regulação estatal da economia, exercida por meio de autarquias integrantes da Administração Indireta, padeceria de uma insanável inconstitucionalidade formal, em decorrência da violação ao princípio da separação de poderes." EIZIRIK et. al. (2008, p. 254).

${ }^{45}$ EIZIRIK et. al. (2008, p. 253).

${ }^{46}$ Trata-se de poder assemelhado ao poder de legislar, conferido pela Constituição Federal, em determinados casos, ao Poder Executivo. Importantes reflexões sobre o tema, o uso e excessos do expediente podem ser encontradas em GUERREIRO (1993, pp. 303-305).

${ }^{47}$ WELLISCH e SANTOS (2010, p. 54).
} 
$\mathrm{O}$ artigo $8^{\circ}$, I, da Lei $6.385 / 76^{48}$, expressamente confere competência à CVM para regulamentar os temas tratados na Lei n. 6.404, de 15 de dezembro de 1976 ("Lei 6.404/76") e na própria Lei 6.385/76 ${ }^{49}$. Essencial notar que, caso a criação de cada uma das normas necessárias à disciplina do mercado de valores mobiliários dependesse da atividade legislativa desempenhada pelo Congresso Nacional, é razoável supor que seriam elaboradas de maneira menos técnica, ágil, eficiente e mesmo democrática (considerando o interessante hábito da Comissão de submeter minutas de normativos aos administrados, em procedimento de audiências públicas ${ }^{50}$ ) do que em comparação com o expediente "descentralizado" criado pelas disposições legais em análise, além da possibilidade de existência de maior sujeição à influência política, em contraposição à atuação da CVM, tendente a ser predominantemente técnica.

A função fiscalizadora (amparada no artigo $9^{\circ}$ da Lei 6.385/76), da qual depende a eficiência de sua atividade sancionadora (a identificação de condutas irregulares é pressuposto para punição dos responsáveis), tem por objetivo primordial coibir a adoção de comportamentos prejudiciais ao mercado e garantir que os participantes atuem conforme as regras ${ }^{51}$.

A aplicação da legislação de maneira preventiva possibilita à CVM, entre outras medidas, promover a suspensão de negociação de valores mobiliários, negar a concessão ou determinar suspensão de registros de ofertas ou companhias, proibir a prática de atos que julgue danosos ao mercado ("stop order") e intimar participantes do mercado ou seus representantes para a prestação de esclarecimentos ${ }^{52}$.

\footnotetext{
48 "Cabe ao Poder Legislativo, por meio de lei, atribuir função regulatória à determinada autarquia especial [...] EIZIRIK et. al. (2008, p. 253).

49 "A disciplina legal das companhias que a LSA classifica como abertas passou, portanto, a compreender, além das leis sobre companhias, as leis especiais sobre mercados de valores mobiliários, seus agentes e instituições, e as regras regulamentares expedidas por aqueles órgãos públicos”. PEDREIRA e LAMY FILHO (2009, p.139). Ainda sobre o tema, destaque para trecho de artigo redigido por ROCHA (1986, p. 65), sintetizador do argumento preponderante: “Ao criar, pela Lei 6.385/76, um órgão administrativo - no caso, uma autarquia federal, vinculada ao Ministério da Fazenda (art. $5^{\circ}$ da lei) - encarregado da disciplina do mercado de valores mobiliários, dotando-lhe de competência normativa para regulamentar as matérias que lhe são afetas, o Legislativo operou uma delegação de funções legislativas, seguindo assim o curso do fenômeno geral de transferência de poder normativo à Administração, fundado nas razões de conveniência $[\ldots]$...

50 Entre 2007 e 2012 foram realizadas 58 (cinquenta e oito) audiências públicas promovidas pela Superintendência de Desenvolvimento de Mercado da CVM e 96 (noventa e três) audiências públicas promovidas pela Superintendência de Normas Contábeis e de Auditoria, muitas das quais resultaram em normativos. Informação disponível em <www.cvm.gov.br/port/redir.asp?subpage=encerrada〉, acessada em 23 nov2012.

51 “[...] o processo administrativo sancionador é o instrumento judicante pelo qual a CVM sanciona os agentes que descumprem as normas de mercado. A certeza da punição do ilícito é fundamental para a redução das infrações cometidas.” DUBEUX (2006, p. 104).

${ }^{52}$ Tais medidas são descritas individualizadamente em SANTOS et. al. (2012, pp. 245-247).
} 
Por seu turno, os mecanismos repressivos de apuração de responsabilidade por infrações às normas do mercado de valores mobiliários, bem como as sanções aplicáveis aos agentes de tais condutas (com necessária observância às garantias aos administrados e princípios que regem a administração pública, constantes da CF/88 e da Lei n. 9.784, de 29 de janeiro de 1999 - “Lei 9.784/99") também estão expressamente previstos na Lei 6.385/76, especificamente em seu artigo $9^{\circ}, \mathrm{V}$ e parágrafo $2^{\circ}$, e artigo 11 , respectivamente.

Deve-se notar que o termo de compromisso está diretamente relacionado às três facetas do poder de polícia da CVM - regulatória, fiscalizatória e sancionatória -, ainda que evidentemente esteja mais relacionado à função sancionadora (que, em alguns casos, chega a ser plenamente substituída por um acordo entre a Comissão e o administrado).

O funcionamento do termo é objeto de pormenorizado regramento infralegal, operado por Deliberações ${ }^{53}$, além de constituir mecanismo diretamente influenciador da atividade de fiscalização, tanto pela possibilidade de ser celebrado ainda antes da instauração de processo administrativo sancionador pela CVM, quanto por ser uma ferramenta para a autoridade sinalizar ao mercado (em adição aos julgamentos administrativos) as condutas e infrações merecedoras de prioridade na repressão, as quais não serão toleradas, relações essas exploradas nos próximos itens.

\subsection{Motivação para a adaptação dos termos de compromisso à realidade nacional}

O entendimento da Comissão de Valores Mobiliários apresentado anteriormente - e explicitado nas consultas e respectivos pareceres-resposta referidos nos itens 2.1 e 2.2 acima - era no sentido de que a celebração de termos de compromisso poderia trazer diversos benefícios à atuação reguladora da autarquia.

Também era clara, conforme reconhecido pelo corpo jurídico da própria Comissão, a necessidade de expressa previsão de tal expediente na legislação aplicável ao mercado de valores mobiliários, pois constituía requisito essencial à possibilidade de serem firmados os acordos, dentro das balizas da expressa legalidade, limitadoras da atuação administrativa.

A introdução dos termos de compromisso no regramento do mercado de valores mobiliários, motivada pelas vantagens potenciais da adoção da consensualidade ${ }^{54}$

\footnotetext{
${ }_{53}$ A serem analisadas nos itens 9,10 e 11 , infra.

54 “[...] a consensualidade consiste em uma técnica de gestão cujo instrumento de formalização corresponde ao acordo administrativo. Isso significa que o acordo administrativo consiste em um dos meios para satisfação das finalidades públicas que a Administração tem ao seu dispor, o que certamente reforça o caráter
} 
na atividade regulatória ${ }^{55}$ - operada observando o trâmite descrito no item 4 abaixo - já havia sido pleiteada e sugerida pela própria CVM, inclusive constando de anteprojeto de lei elaborado pela Comissão com o escopo de aperfeiçoar sua atuação e incrementar o desenvolvimento do mercado ${ }^{56}$.

\title{
3.2. Anteprojeto de Lei elaborado pela CVM
}

Em 1986, portanto mais de uma década antes da vigência da lei que incluiu os parágrafos legitimadores da celebração dos termos de compromisso no mercado de valores mobiliários brasileiro, um anteprojeto de legislação alterando de forma ampla a Lei $6.385 / 76$ já tratava, entre outros temas, da previsão de tal instituto ${ }^{57}$.

Descrevendo o anteprojeto, em artigo contemporâneo à sua elaboração, e apresentando o termo de compromisso de forma assemelhada ao que viria a ser incorporado ao ordenamento quase um decênio depois, Nelson Eizirik - então Diretor da Comissão de Valores Mobiliários - explicava que

\begin{abstract}
"O Anteprojeto prevê, ainda, a possibilidade de suspensão do procedimento administrativo se o indiciado obrigar-se, mediante termo de compromisso, a cessar a prática de determinado ato ou a tomar as medidas necessárias à correção das irregularidades apontadas. Trata-se de adaptação do instituto do 'consent decree', instrumento útil visando, em certos casos, substituir a aplicação de penas por providências, a serem tomadas pelos indiciados, capazes de reparar os efeitos danosos das irregularidades" ${ }^{58}$.
\end{abstract}

$\mathrm{O}$ anteprojeto não logrou êxito, sequer foi apresentado à Câmara dos Deputados, e modificações à Lei 6.385/76 vieram a ser promovidas apenas posteriormente, em movimentos difusos ocorridos nos anos de 1997, 2001, 2002 e 2011.

instrumental da atuação administrativa consensual dado o enfoque no fim de interesse público que a Administração deve perseguir". PALMA (2010, p. 128).

${ }^{55}$ Nesse sentido, em texto publicado pouco após a publicação da Lei 9.457/97, o Professor Verçosa (1998, p. 203)observou tratar-se da "adoção de uma nova visão não mais estritamente punitiva da lei, mas que busca a solução efetiva quanto à cessação de práticas ilícitas no mercado de valores mobiliários".

56 "Na verdade, todas as decisões (na área regulatória e no exercício da função fiscalizadora) que devem ser adotadas pelos funcionários da CVM, desde os seus técnicos, e até os seus dirigentes, têm por objetivo final proporcionar ao mercado regras de funcionamento melhores e mais eqüitativas, o que possibilita, indubitavelmente, o desenvolvimento do mercado. Num segmento da atividade econômica em que o poder público cumpre adequadamente as suas funções de agente regulador e fiscalizador da atuação dos particulares, é inegável que resulte um aperfeiçoamento das práticas daqueles que se utilizam do mercado, o que the proporciona maior credibilidade e confiabilidade e, por conseguinte, uma possibilidade real de expansão crescente. " CANTIDIANO (1999, p. 27).

${ }_{57}$ Reportaram CARVALHOSA e EIZIRIK (2002, p. 436) que "Em 1986, foi elaborado pela CVM um Anteprojeto objetivando empreender a reforma integral da Lei n. 6.385/76, com os seguintes objetivos básicos: [...] introduzir o instituto do 'termo de compromisso' [...]".

${ }^{58}$ EIZIRIK (1986, p. 30). 
Foi, assim, momentaneamente frustrado o objetivo da Comissão, por quem os termos de compromisso eram vistos como método alternativo de promoção de enforcement, pois seria garantida a oportunidade de a autoridade escolher, em cada caso, qual das ferramentas aplicar (na pressuposição de apresentação de proposta de acordo pelo administrado). Seria, portanto, no entender dessa autarquia, uma alternativa aos processos administrativos sancionadores, quando o interesse público assim entendesse viável e adequado.

\subsubsection{Termo de compromisso como alternativa de enforcement}

O interesse da CVM em poder fazer uso dos termos de compromisso pode ser interpretado como busca de método complementar à sua atuação sancionadora tradicional, de inspiração penal, com incremento de eficiência na alocação dos seus recursos humanos e materiais ${ }^{59}$. Pode-se entender que a iniciativa estava inserida no contexto de aprimoramento da atuação dessa autarquia, para adoção de postura mais próxima de uma agência efetivamente "reguladora", dotada de meios efetivos para sinalização de suas prioridades ao mercado.

O termo de compromisso, entre outros mecanismos, serviria para impulsionar a regulação sob uma ótica alternativa, mais eficiente ${ }^{60}$, balanceando entre medidas de cunho quase penal e aquelas de caráter preponderantemente administrativo. Trata-se, portanto, de ferramenta adicional ao arsenal de instrumentos regulatórios ${ }^{61}$ disponibilizados para o atingimento dos objetivos da autarquia, configurando-se em "eficaz instrumento de enforcement da CVM"62.

Naturalmente, essa "inovação" não viria a substituir os mecanismos tradicionais de sanção ${ }^{63}$, até porque eles constituem um poder essencial, circunscrito por

\footnotetext{
${ }^{59}$ A potencialização da atividade sancionadora em decorrência da adoção dos termos de compromisso, e o incremento do enforcement com a possibilidade de celebração dos acordos substitutivos será objeto de atenção no item 6.1 .

60 "A CVM, obedecendo os postulados da economia de mercado, persegue um mercado de valores mobiliários eficiente, que, para tanto, precisa ser livre, competitivo e informado, e deseja também um mercado confiável como resultado de uma adequada proteção e harmonização dos interesses de todos que nele transacionam. A confiabilidade e a eficiência são, portanto, requisitos fundamentais para a existência e para o pleno e regular desenvolvimento do mercado de valores mobiliários". SANTOS, WELLISCH e BARROS (2006, p.82).

${ }^{61}$ "A ação regulatória do Estado se dá por meio de instrumentos regulatórios, que nada mais são do que ferramentas constituídas pela legislação aplicável a um determinado setor para que a autoridade regulatória competente possa realizar a sua atuação e, assim, alcançar as finalidades previstas na lei para o perfeito funcionamento do setor regulado". SCHIRATO (2006, p. 205).

${ }^{62} \operatorname{LEMOS}(2005$, p. 21).

${ }^{63}$ "A CVM, em decorrência do poder de polícia que lhe é delegado pela Lei n. 6.385/76, titulariza também o poder legal de impor sanções aos agentes do mercado de valores mobiliários, com vistas a preservar a integridade dos princípios consagrados na legislação vigente e, principalmente, proteger os investidores
} 
um método que pode se dizer irrenunciável por qualquer autoridade que pretender a manutenção da ordem no contexto em que atue. Nas palavras do Professor GUERREIRO, referindo observação de RIPERT, de que a lei só é respeitada em função da certeza de que será inútil a ela resistir:

\footnotetext{
"Transplantada a observação para o campo do direito disciplinar, só se combaterá eficazmente o espírito de desobediência na medida em que todos os destinatários das respectivas normas se compenetrarem da inevitabilidade das sanções repressivas. E preciso será, naturalmente, que as sanções sejam, de fato, inevitáveis" ${ }^{64}$.
}

Também a doutrina brasileira, anos após o fracasso do anteprojeto - mas ainda antes da inclusão da previsão do termo de compromisso na Lei 6.385/76 - reconhecia a pertinência do funcionamento dos termos de compromisso no mercado de valores mobiliários brasileiro e também sua potencial utilidade, como ferramenta alternativa dotada de efeitos positivos ao sistema ${ }^{65}$.

atraídos a esse mercado contra atos lesivos praticados em dissonância com tais princípios". Parecer/CVM/PJU/005, de 10 de março de 1998.

${ }^{64}$ GUERREIRO (1981, p. 78).

65 “Como tornar mais eficazes as normas? As receitas são conhecidas, embora até hoje não aplicadas: [...] 6. criar a figura do consent decree, de tal forma que os inquéritos da CVM possam ser suspensos, caso indicado assine termo de compromisso obrigando-se a cessar a prática do ato ilícito ou a corrigir as irregularidades verificadas.” EIZIRIK (1995, p. 60). 


\section{INTRODUÇÃO DO TERMO DE COMPROMISSO NA LEI 6.385/76 PELA REFORMA DE 1997 (LEI 9.457/97)}

Ainda que anteriormente já tenha sido discutida, inclusive pela CVM (em expedientes internos ${ }^{66}$ e anteprojeto de alteração da legislação então vigente ${ }^{67}$ ), e tenha sido objeto de referência específica na melhor doutrina, como analisado nos itens antecedentes, a inclusão do termo de compromisso na Lei 6.385/76 ocorreu de fato apenas com o Projeto de Lei n. 1.564/1996 (“PL 1.564”), de autoria do Deputado Antônio Kandir.

Durante seu trâmite no Congresso Nacional, determinou-se que tal projeto fosse apensado ao Projeto de Lei n. 622/1995 (“PL 622”), apresentado pelo Deputado José Fortunati, o qual, após discussões, trâmites e a elaboração de um substitutivo, finalmente veio a ser aprovado, originando a Lei 9.457/97, publicada no Diário Oficial da União em 6 de maio de 1997.

O objetivo da Lei 9.457/97, nos itens reformadores da Lei $6.385 / 76^{68}$ especificamente no tocante à competência da CVM - foi desde o início do processo legislativo bastante evidenciado ${ }^{69}$. Já na justificação apresentada quando da publicação do PL 1.564, o deputado Kandir afirmou que "com base no entendimento de que o desenvolvimento do mercado de capitais exige fiscalização eficaz por parte de seu órgão regulador, o projeto de lei define modificações que melhor instrumentalizam a CVM para desincumbir-se de suas atribuições de proteção ao investidor”.

Reconhecidamente fazia-se necessário dotar a CVM de novas ferramentas para inibir e reprimir ilícitos administrativos como uma das formas de aprimorar a sua atuação. Uma reforma ampla do artigo 11 da Lei 6.385/76 surgia como o plano para tal melhoramento, com a proposição de "alterações que visem ao fortalecimento da Comissão de Valores Mobiliários, atribuindo-lhes novas prerrogativas de fiscalização", como referiu o relator do PL 622, o deputado Luiz Carlos Hauly.

A inserção da previsão do termo de compromisso, que observou o trâmite no Congresso Nacional retratado anteriormente, ocorreu, então, simultaneamente a diversos outros ajustes à Lei 6.385/76, também operados pela Lei 9.457/97 (cuja referência interessa para a completa contextualização do momento regulatório relatado no item 3.2

\footnotetext{
${ }^{66}$ Cf. itens 2.1 e 2.2 acima.

${ }^{67}$ Cf. item 3.2 acima.

${ }^{68}$ A Lei 9.457/97 também alterou dispositivos da Lei 6.404/76, não abrangidos no presente trabalho.

${ }^{69}$ Para maiores informações sobre o trâmite legislativo e visão panorâmica da reforma, entre outros, cf. CARVALHOSA (2000).
} 
supra), entre as quais destaque para as modificações dos mecanismos à disposição da CVM para o exercício de seu poder de polícia.

Tais outros ajustes, inclusive, eram essenciais à função a que se destinou e aos préstimos do termo de compromisso, pois, desde muito tempo, era sabido que "na prática o instituto teria pouca utilidade enquanto não fosse estabelecido um elenco de penalidades para as infrações consideradas graves" ${ }^{\text {, }}$. A seguir, tais alterações serão descritas e avaliadas.

A primeira alteração promovida pelo diploma de 1997 na Lei $6.385 / 76$ foi a inclusão dos membros de conselhos fiscais das companhias abertas na lista de indivíduos cuja ação ou omissão pode ensejar responsabilização no âmbito administrativo, constante do artigo $9^{\circ}, \mathrm{V}$, da lei alterada. Adicionou-se, portanto, os conselheiros fiscais infratores às normas da citada Lei, da Lei 6.404/76 e das regras infralegais ao rol de indivíduos sujeitos às sanções previstas no artigo 11 da Lei 6.385/76, até então composto exclusivamente por administradores (conselheiros e diretores) e acionistas de companhias abertas, além de intermediários e demais participantes do mercado.

Seguiu-se com a mudança do inciso III do artigo 11, introduzindo a possibilidade de suspensão do exercício de cargos para conselheiros fiscais e integrantes de quaisquer entidades que dependam de autorização ou registro na CVM, em adição aos agentes que já eram passíveis de tal punição sob a regra original (administradores de companhias abertas e de entidades do sistema de distribuição). Tal modificação, como aquela comentada no parágrafo anterior, teve o escopo de tornar mais clara a lista de pessoas sujeitas à fiscalização da Comissão e, consequentemente, às punições, caso consideradas responsáveis por infrações, em processo administrativo sancionador. Como é possível perceber, passou a existir previsão expressa na Lei 6.385/76 para responsabilização dos conselheiros fiscais, com aplicação de todas as sanções previstas nessa Lei, inclusive com a suspensão do exercício de cargos e inabilitação.

Outra novidade foi o estabelecimento de um limite (até o máximo de vinte anos) para a pena de inabilitação temporária dos agentes infratores ${ }^{71}$. Ficou, então, restrito o período máximo de condenação e, sobretudo, eliminada a dúvida sobre a possibilidade de aplicação de tal sanção - em razão, principalmente, da anterior inexistência de um

\footnotetext{
${ }^{70}$ ARAGÃO e SANTOS (1979, p. 7).

${ }^{71}$ Penalidade determinada no inciso IV do artigo 11 da Lei 6.385/76.
} 
intervalo máximo - além de expressamente eliminando a hipótese de inabilitação definitiva, inconstitucional nos termos do artigo $5^{\circ}$, XLVII (b), da CF/ $88^{72}$.

Além de ajustes às punições já existentes, duas novas sanções, de notável gravidade, foram adicionadas pela Lei 9.457/97 à relação daquelas até então já à disposição da CVM. A primeira é a "proibição temporária, até o máximo de vinte anos, de praticar determinadas atividades ou operações, para os integrantes do sistema de distribuição ou de outras entidades que dependam de autorização ou registro na Comissão de Valores Mobiliários" (inciso VII do artigo 11 da Lei 6.385/76). Com tal novidade, tratou o legislador de conferir à Comissão poder para afastar o apenado da prática de atividades ou operações específicas, sem que seja necessário adotar medida extrema, como cassar o registro ou autorização e, assim, inviabilizar a prática da totalidade de atos que dependam de registro, nos termos legais. É uma pena que parece ser destinada às entidades reguladas pela CVM e que se situa em um patamar intermediário, sendo notavelmente menos gravosa que a cassação de autorização, e destinando-se a restringir a atuação do apenado no mercado, sem eliminá-la.

A outra possibilidade de pena a ser aplicada pela Comissão, introduzida pela Lei 9.457/97, é a “proibição temporária, até o máximo de dez anos, de atuar, direta ou indiretamente, em uma ou mais modalidades de operação no mercado de valores mobiliários" (inciso VIII do artigo 11 da Lei 6.385/76). É interessante e significativa a inovação da lei nesse ponto, cujo objetivo é prevenir a reincidência de infratores condenados pela Comissão - mas que não dependam de autorização ou registro na CVM para desempenharem suas atividades (investidores são o exemplo mais notório) - em atividades que causem prejuízo ao mercado.

Também as multas ${ }^{73}$, a penalidade mais aplicada pela CVM à época da Lei 9.457/97, e também atualmente, sofreram diversas mudanças: aumento do valor máximo, o qual passou a ser determinado em moeda corrente nacional; aumento do percentual incidente a título de multa, quando for variável em relação à ação ou omissão faltosa; e incremento das multas a serem aplicadas pela autarquia quando verificada reincidência pelo infrator.

Os limites para a pena de multa, estabelecidos no parágrafo $1^{\circ}$ do artigo 11 da Lei $6.385 / 76$, foram sensivelmente ampliados. O primeiro dos limites foi alterado de

\footnotetext{
72 Sobre o tema, afirma ATALIBA (1994, p.16): "Proibindo a Constituição penas perpétuas, é evidente que às demais sanções - necessariamente correspondentes a infrações menos graves - aplica-se a mesma limitação".

${ }^{73}$ A respeito dos aspectos regulatórios das multas determinadas pela CVM, cf. PAULIN (2008).
} 
“quinhentas vezes o valor nominal de uma Obrigação Reajustável do Tesouro Nacional" para $\mathrm{R} \$ 500.000,00$ (quinhentos mil reais) ${ }^{74}$, representando majoração bastante significativa ${ }^{75}$.

Adotando a mesma lógica, também foi incrementado o limite para cominação de multas proporcionalmente ao valor da emissão ou operação irregular, que passou de $30 \%$ (trinta por cento) para 50\% (cinquenta por cento). Também foi acrescentado um inciso III ao parágrafo $1^{\circ}$ do artigo ora analisado, delineador de nova forma de limite máximo para cálculo de multa a ser aplicada pela Comissão: "três vezes o montante da vantagem econômica obtida ou da perda evitada em decorrência do ilícito". O enunciado claramente indica ser aplicável nos casos de negociação de valores mobiliários por possuidor de informações privilegiadas.

Esses novos limites parecem ser mais adequados e fundamentados para desestimularem as condutas à margem da legislação, especialmente quando for verificada a hipótese de relação entre a vantagem obtida pelo agente e a punição, por guardar proporcionalidade entre a conduta e a pena ${ }^{76}$.

É fácil constatar, portanto, que a Lei 9.457/97 aumentou de forma substancial o limite das multas que podem ser aplicadas aos infratores condenados em processos sancionadores conduzidos pela CVM. Some-se a isso a criação de regra possibilitando, em caso de reincidência, (i) a majoração da multa, em até o triplo do que seria aplicado a condenados "primários", ou (ii) a aplicação de penas restritivas de liberdade de iniciativa (suspensões, inabilitações, cassações de registros ou proibição de atuação), mesmo que a reincidência não ocorra no cometimento de infrações de natureza grave ${ }^{77}$ (única hipótese de aplicação de tais penas, para um sancionado em condição de primariedade).

Ainda com relação às multas, a Lei 9.457/97 modificou aquela aplicável em decorrência da inexecução de ordem específica emitida pela CVM, anteriormente tratada no parágrafo $2^{\circ}$ do artigo $11^{78}$. A nova lei elevou sensivelmente o valor da multa, de "dez

\footnotetext{
${ }^{74}$ O PL 1.564 previa multa máxima de R \$5.000.000,00 (cinco milhões de reais), porém o limite foi reduzido no substitutivo apresentado pelo Deputado Luiz Carlos Hauly, aprovado no Congresso Nacional.

75 O valor das Obrigações Reajustáveis do Tesouro Nacional foi intensamente impactado por conta da inflação e pelas sucessivas substituições do mencionado índice e, em 1997, representava quantia pouco expressiva.

76 Observou BOCATER (1999, p. 212) que "As penalidades previstas na Lei 6.385/76 foram alteradas para contemplar multas mais adequadas à gravidade dos ilícitos".

${ }_{77}^{7}$ São graves as infrações indicadas na Instrução CVM n. 491, de 22 de fevereiro de 2011.

${ }^{78}$ Tal pena é disciplinada pela Instrução CVM n. 452, de 30 de abril de 2007, que a denomina "multa extraordinária", em contraposição à chamada "multa ordinária". É extraordinária a multa que não é decorrente de desatenção a uma ordem específica da CVM, mas derivada de inadimplemento de obrigação de prestação de informações periódicas ou extraordinárias, estabelecidas previamente em normas do mercado de valores mobiliários.
} 
vezes o valor nominal de uma Obrigação Reajustável do Tesouro Nacional” para até $\mathrm{R} \$ 5.000,00$ (cinco mil reais), sempre de incidência diária. Ainda, clarificou que (i) a aplicação de tal tipo de multa independe de novo procedimento administrativo (artigo 11, parágrafo 11); e (ii) da decisão que aplicar tal multa caberá recurso, no prazo de 10 (dez) dias, à Diretoria Colegiada, sem efeito suspensivo (parágrafo seguinte, do mesmo artigo).

A penúltima inovação da Lei 9.457/97 em relação ao poder punitivo da CVM derivou de determinação do novo parágrafo $9^{\circ}$ do artigo 11, que estipulou a consideração pela Comissão, na aplicação das penalidades, de arrependimento eficaz, arrependimento posterior, confissão espontânea de ilícito ou prestação de informações relativas à respectiva materialidade, figuras trazidas de direito penal e que potencialmente reduziriam a pena a ser determinada, após decisão administrativa condenatória.

A última alteração tratou exatamente da inserção da previsão do termo de compromisso na legislação sobre a fiscalização e proteção ao mercado de valores mobiliários $^{79}$. Essa mudança, segundo o próprio autor do projeto legislativo reformador, foi a principal modificação trazida pela Lei $9.457 / 97$ em relação à atuação reguladora sobre o mercado de valores mobiliários:

\footnotetext{
"Mais importante, no entanto, é a inovação que permite a CVM fazer acordos com parte envolvida em operações ilegais [...]. Nos termos deste projeto de lei, a CVM fica autorizada a suspender o processo administrativo, se o acusado, além de comprometer-se a cessar a prática considerada ilícita e consentir na aplicação da penalidade, dispuser-se a prestar informações relativas à materialidade do ilícito, bem como às demais pessoas envolvidas no mesmo [...]"»80.
}

Nota-se, então, que, ao mesmo tempo em que a CVM passou a ter à disposição apenações mais variadas e rigorosas para aplicação aos infratores, sendo possível, ao menos em tese, adequar melhor a punição às condutas, e agir de forma mais intensa quando julgasse necessário, passou a contar com uma ferramenta adicional e alternativa na condução da fiscalização e investigação das ações dos agentes. A então novidade, é consenso, conferiu uma "flexibilidade maior dos procedimentos sancionadores da CVM,

\footnotetext{
${ }^{79}$ Vista com bons olhos, entre outros, por BOCATER (1999, p. 212), antecipando alguns dos argumentos que serão oportunamente abordados: "A possibilidade de se fazerem termos de compromisso, com indenização das partes prejudicadas, é também inovação importante, pois trata-se de instrumento de extrema utilidade, na medida em que evita a necessidade de recurso ao Poder Judiciário, possibilitando uma ação mais imediata, com repercussão concreta para os investidores prejudicados."

${ }^{80}$ Justificação apresentada pelo Deputado Antonio Kandir, em 28 de fevereiro de 1996. Ainda que o último dos requisitos, assemelhado à delação premiada, não tenha sido mantido na redação final das regras sobre o termo de compromisso, o seu núcleo - motivo de entusiasmo do parlamentar que o propôs - já havia sido plasmado no projeto.
} 
ao prever a possibilidade de sua suspensão mediante a assinatura do termo de compromisso" 81 .

Racionalmente analisando, apenas faria sentido a aplicação do termo de compromisso no contexto do mercado de valores mobiliários caso existissem punições às quais o novo instrumento pudesse ser visto, pelos supostos infratores, como alternativa. Seria de pouca utilidade a introdução do mecanismo desacompanhada da possibilidade de a CVM aplicar penas mais severas aos agentes transgressores das regras do mercado: inexistiria o estímulo ${ }^{82}$ à sua proposição pelos administrados, confortáveis com as penas a que poderiam ser submetidos, em caso de condenação.

A introdução dos termos de compromisso ocorreu, assim, no contexto de aperfeiçoamento das ferramentas disponibilizadas pela legislação para a atividade fiscalizadora e sancionatória da CVM, com maior rigidez e penas mais severas. Não poderia, nesse cenário e considerando tais premissas, ser o instituto em exame interpretado como alternativa para atenuar o tratamento recebido pelos investigados ou acusados, mas sim como uma ampliação do poder de polícia da Comissão de Valores Mobiliários ${ }^{83}$.

\subsection{Natureza do termo de compromisso}

Apresentada a função e revista a motivação para introdução do instituto, as próximas linhas objetivarão tratar da natureza jurídica dos termos de compromisso celebrados entre a CVM e agentes sob sua supervisão e fiscalização, exclusivamente para identificação do regime jurídico aplicável a tais acordos.

EIZIRIK et. al. (2008, p. 340) afirmam que "o termo de compromisso pode ser considerado uma transação", fazendo referência à disciplina civil desse instituto, o qual “constitui negócio jurídico bilateral mediante a qual as partes previnem ou extinguem relações jurídicas duvidosas ou litigiosas, por meio de concessões recíprocas ou ainda em troca de determinadas vantagens pecuniárias".

Considerando o texto da Lei n. 10.406, de 10 de janeiro de 2002 ("Código Civil”), parece não ser possível a subsunção do termo de compromisso, firmado entre a

\footnotetext{
${ }^{81}$ EIZIRIK (1998, p 84).

${ }^{82} \mathrm{O}$ qual será analisado no item 6.2.

${ }^{83}$ COSTA (2000, p. 136), tratou do tema como o endereçamento de solução de "falhas estruturais": "Dois aspectos apontados como falhas estruturais receberam tratamento adequado nas alterações normativas promovidas pela Lei 9.457/97 e pela Medida Provisória n. 1.637, de 08.01.98. Seus dispositivos ampliaram o poder de polícia, agravaram as penalidades dotando-as de valores e consequências dissuasivas, ampliaram a responsabilização dos administradores e instituíram o 'consent decree' (possibilitando a suspensão de inquéritos instaurados pela CVM, caso o indiciado cesse a prática ilícita e sane as irregularidades). As substanciosas modificações foram introduzidas nos artigos $9^{\circ}$ e 11 da Lei 6.385/76".
} 
Comissão e os administrados, à categoria de transação, prevista no Capítulo XIX ("Da transação"), integrante do Título VI ("Das várias espécies de contrato”) do Livro I ("Do direito das obrigações"), na Parte Especial do Código Civil.

Certamente há características constantes da lei civil, relativas à transação, que são comuns ao termo de compromisso firmado no âmbito do mercado de valores mobiliários; essencialmente o seu conceito, fundado na permissão, às partes, para realizarem concessões mútuas, objetivando prevenir ou terminar litígio. O mesmo não se pode dizer, contudo, da redação do artigo 841 do Código Civil que, ao restringir o objeto da relação transacional típica de natureza civil a afasta do pacto celebrado entre a Comissão e os administrados no âmbito do mercado de valores mobiliários ${ }^{84}$. Assim, não sendo preenchido um dos requisitos essenciais do modelo contratual típico (objeto), não é possível afirmar estarmos diante de um exemplo de tal modelo, não sendo adequado atribuir, com propriedade, ao termo de compromisso natureza de transação tal qual contemplada no diploma civil.

Parece ser a tendência dos estudiosos do tema a construção de uma categoria específica para classificação dos acordos substitutivos firmados entre a administração pública e particulares, com influência das regras civis da transação. Entretanto, fazem-no com adição de elementos específicos do direito público ${ }^{85}$, vez que produz efeito sobre relação de direito administrativo, decorrente do poder fiscalizatório e sancionador da Comissão.

O termo de compromisso é, sem dúvidas, um acordo ${ }^{86}$, formado a partir de proposta apresentada exclusivamente pelo administrado à Comissão, e que se conclui pela aceitação dos termos propostos pelo Colegiado da CVM. Aceitação essa de natureza facultativa, pois a oferta não vincula a Comissão, a quem cabe analisar se o proposto atende de forma mais adequada ao interesse público ou se, ao contrário, melhor proteção

\footnotetext{
${ }^{84}$ No mesmo sentido, mas embasada por argumento diverso, PALMA (2010, p. 131): “[...] o Direito Administrativo dispõe de variados acordos administrativos, cada qual com funcionalidade e regimes diferenciados. É inviável, portanto, afirmar uma natureza comum a todos os instrumentos consensuais positivados, o que, inclusive, seria um limitador à dinâmica consensual. Quanto mais sujeitar os acordos administrativos à disciplina civilista, cujo instrumento de transação civil se destina a questões próprias do sistema civil. [...] Ademais, é necessário ressaltar a ausência de previsão normativa expressa que determine a aplicação subsidiária das normas de Direito Civil à atuação administrativa consensual”.

${ }^{85}$ Para BATISTA JÚNIOR (2007, p. 527), “[...] contrato administrativo alternativo é contrato vinculante, de subordinação, pelo qual a Administração e administrados, mediante concessões recíprocas, [...] efetivamente constituem, modificam ou extinguem relação jurídica típica de direito administrativo, no intuito de possibilitar uma atuação consensual mais democrática da Administração, alternativa à emanação de ato unilateral imperativo, ou de prevenir ou terminar controvérsias, buscando, assim, maior eficiência na atuação administrativa, quando desenvolvida com a colaboração do administrado".

${ }^{86} \mathrm{Na}$ dicção de PALMA (2010, p. 248), “[...] trata-se de um acordo administrativo na medida em que a sua formalização condiciona-se à manifestação bilateral de vontade entre Poder Público e interessado".
} 
pode ser conferida para os direitos tutelados com a recusa do oferecido e o seguimento usual do processo administrativo ${ }^{87}$.

No que concerne a seus aspectos formais, a legislação determina a sua celebração sob a forma escrita ${ }^{88}$, e a publicação de seu inteiro teor no Diário Oficial da União $^{89}$.

Deve-se destacar que não há direito à celebração de um termo de compromisso como um direito potestativo, da espécie direito formativo gerador ${ }^{90}$. Sequer configura-se um direito subjetivo ${ }^{91}$ do agente do mercado de valores mobiliários, ao qual corresponderia um dever da CVM à celebração de tal acordo $^{92}$. É direito do administrado apresentar uma proposta de termo de compromisso, a qual será objeto de apreciação pelo regulador, considerando os seus objetivos e deveres ${ }^{93}$.

\footnotetext{
${ }^{87}$ Analisada no item 9.2.5, infra.

88 A celebração do acordo depende da assinatura de um termo de compromisso, escrito, conforme determinado pelo artigo 11 , parágrafo $5^{\circ}$ da Lei $6.385 / 76$.

${ }^{89}$ Conforme referido no item 9.2.8, infra.

${ }^{90}$ Conforme explicado no $\$ 566$, item 2, t. 5, do Tratado de Direito Privado de PONTES DE MIRANDA: "Tais direitos se exercem por ato unilateral do titular, ou seja por declaração unilateral de vontade ao interessado [...]".

${ }^{91}$ Afirma-se que existe direito subjetivo, por exemplo, na suspensão condicional do processo penal: o réu que atendesse à totalidade dos requisitos objetivos e subjetivos fixados na lei teria direito à suspensão do processo. Não haveria, em tal caso, liberalidade dos agentes do Estado, que não poderiam negar tal direito e preferir, exemplificativamente, prosseguir com o trâmite natural do processo penal. Trata-se de suposto exemplo do chamado ato vinculado da administração, em que inexistiria juízo de conveniência e oportunidade (fundamentos do termo de compromisso). Há, entretanto, intensa discussão a respeito do tema, coexistindo posições diametralmente opostas: o Ministério Público do Estado de São Paulo expressou seu posicionamento pela sua tese 117, publicada no Diário Oficial do Estado de 12 de junho de 2003, que estabelece: "A suspensão condicional do processo é ato discricionário do representante do Ministério Público. Se houver recusa deste, deve o Juiz remeter os autos ao Procurador-Geral de Justiça, por aplicação analógica do artigo 28 do Código de Processo Penal." Por outro lado, há posições de igual relevância apontando para existência de direito subjetivo do réu. Exemplificativamente, Alfredo José Marinho Neto, integrante da magistratura estadual do Rio de Janeiro, em artigo disponibilizado no website do tribunal estadual, afirma que "Desta forma, tratando-se a suspensão condicional do processo de um direito subjetivo do réu, que pode ensejar até a nulidade do processo se não lhe for dada oportunidade para gozá-lo, é dever do magistrado oferecer essa oportunidade ao réu na hipótese de recusa injustificada ou improcedente por parte do órgão de acusação." MARINHO NETO, A. J., Suspensão condicional do processo - pode o juiz oferecê-la de ofício? Rio de Janeiro, 200. Disponível em <http://www.tjri.jus.br/web/guest/institucional/dirgerais/dgcon/artigos-juridicos > acesso em 20out2013. No mesmo sentido, GRINOVER, Ada Pellegrini Grinover et. al. Juizados Especiais Criminais - Comentários à Lei 9.099, de 26.09.1995. São Paulo: Revista dos Tribunais, 1996, p. 210; e BATISTA, Weber Martins. Suspensão condicional do processo: natureza jurídica; iniciativa da proposta. Revista CEJ, n. 04, abril 1998.

92 "Todo direito subjetivo, como produto da incidência de regra jurídica, é limitação à esfera de atividade de outro, ou de outros possíveis sujeitos de direito." Conforme explicado no $§ 564$, item 2, t.5, do Tratado de Direito Privado de PONTES DE MIRANDA.

${ }^{93}$ Inexiste registro de discussão em juízo a respeito da existência de um direito do agente econômico na celebração dos termos de compromisso com a CVM, como existe, v.g., no contexto concorrencial, conforme
} relatado no item 4.5 . 
O conteúdo do pacto é composto por concessões mútuas (mais especificamente renúncias mútuas ${ }^{94}$ ), sendo (i) as medidas a serem adotadas pelo compromitente (devendo obrigatoriamente constar compromisso de correção das irregularidades e indenização de prejuízos identificados, bem como cessação da conduta sob suspeita de ilicitude, e sendo facultada a inclusão de outras obrigações); e (ii) o compromisso da Comissão de, uma vez atestado e homologado o cumprimento das obrigações contraídas, arquivar o procedimento administrativo (inquérito, processo sancionador ou mesmo uma inspeção) em relação ao compromitente cumpridor ${ }^{95}$, sem o exercício de suas prerrogativas habituais.

A negociação ocorre em relação às condições que o investigado ou acusado aceita se submeter (mais precisamente, a propor), com a limitação de direitos e liberdades dos signatários, pelo que a própria CVM afirmou ser o termo de compromisso uma “exteriorização do poder de polícia” por ela exercido ${ }^{96}$. Também toca à negociação ${ }^{97}$ a renúncia ao exercício da prerrogativa pública pelo seu titular, com a concordância da autoridade administrativa em renunciar ao exercício de ferramenta sancionadora, satisfazendo-se com as obrigações assumidas pelo particular ${ }^{98}$.

Importante ressaltar inexistir renúncia da administração na punição de infrações identificadas e caracterizadas, o que acarretaria desvio de conduta dos administradores. $\mathrm{O}$ administrado renuncia ao seu direito de defesa, que poderia propiciar a sua absolvição, e a Comissão renuncia ao exercício de prerrogativas sancionatórias,

\footnotetext{
94 “O objeto desse contrato, em sua maior parte, são direitos, mais propriamente a renúncia a direitos ou ao exercício destes, cuja capacidade para a prática do ato de disposição foi conferido à autoridade pela lei, bem como, por parte da representada, pertence à sua esfera de direitos renunciáveis e disponíveis".

Voto do Conselheiro Paulo Furquim de Azevedo, relator do Requerimento 8700.004992/2007-43, no contexto do Processo Administrativo 08012.011142/2006-79, p. 5.

${ }^{95}$ Há também, caso seja o compromitente adimplente o único administrado participante do procedimento que originou o acordo, a extinção do procedimento administrativo, conforme o item 9.2.1, infra.

96 “[...] há que se ter em vista que a referida transação restringe-se à negociação das condições às quais o indiciado ou acusado aceita submeter-se, esgotando-se a bilateralidade do ato com o consentimeto do acusado em aderir ao termo de compromisso. Seu conteúdo, contudo, é autêntica exteriorização do poder de polícia exercido pela CVM, no sentido em que limita e disciplina os interesses, direitos e liberdades dos que se tornarem seus signatários, fazendo-o não através de penalidades, mas por meio de comandos expressos de cessação de prática irregular e indenização de prejuízos causados a investidores". Parecer/CVM/PJU/005, de 10 de março de 1998.

97 "Como se vê, o termo de compromisso confere evidente flexibilidade à entidade reguladora, com vistas a proporcionar o máximo de eficiência na solução de problemas, aliando, na dosagem necessária para cada hipótese, as vantagens da flexibilidade negocial privada com o rigor da coercetividade estatal". DUBEUX (2006, p. 99).

98 “[...] o objeto da negociação é a prerrogativa pública (no extremo, a prerrogativa imperativa), tanto quanto ao uso dessa prerrogativa pelo agente público como com relação à medida do exercício do poder de autoridade estatal. [...] Esta dinâmica de negociação implica, portanto, na substituição de uma sanção administrativa de advertência por obrigações de fazer ou de não fazer pelo administrado, por exemplo". PALMA (2010, p. 129).
} 
colocando-se sempre a conduta que ensejou o procedimento administrativo em uma situação de incerteza em relação à respectiva ilicitude ${ }^{99}$.

Assim, o acordo firmado é consensual quanto à sua formação; porém, é "impositivo em seus efeitos", caracterizando-se como um instituto misto, tangendo aspectos de direito privado e de direito público ${ }^{100}$. A parte do termo que se situa na esfera do direito administrativo explica, por exemplo, que o adimplemento do compromisso prestado pela CVM depende da prévia satisfação das obrigações propostas pelo proponente $^{101}$, embora esteja desde $\operatorname{logo}$ vinculada $^{102}$ a, tão $\operatorname{logo}$ seja concluída a prestação devida, formalizar o arquivamento do procedimento administrativo com relação ao proponente.

\subsection{Análise da possibilidade jurídica da celebração dos acordos substitutivos}

Principalmente após a introdução dos termos de compromisso no ordenamento brasileiro, foram apresentadas críticas a respeito da legalidade de um acordo firmado entre a CVM e os particulares, questionando a "negociabilidade" de interesses supostamente indisponíveis pela autoridade administrativa e a renúncia do jus puniendi, que seria inafastável.

\footnotetext{
${ }^{99}$ Nas palavras de FONSECA (2001, pp. 250-253), “A criação legal do 'compromisso de cessação' deixa no âmbito da incerteza a infringência contra ordem econômica. Este compromisso se insere no instituto jurídico da transação. [...] As características da transação se evidenciam como um acordo, que se manifesta com o propósito de extinguir um litígio, em que existe uma reciprocidade de concessões e em que permanece inequívoca a incerteza quanto ao direito das partes. Na verdade, diferentemente do acordo no âmbito civil, aqui ocorre um acordo entre a autoridade encarregada de investigar e o representado cuja atividade econômica se analisa. Com esse acordo se extingue ou se paralisa a investigação, havendo reciprocidade de concessões: a autoridade não investiga mais e o representado paralisa a prática de atos que geraram suspeitas da infração da ordem econômica. O elemento da incerteza, de dúvida, está presente porque nem a autoridade nem o representado têm segurança sobre o desfecho da investigação, que poderia confirmar a existência da infração, mas poderia também afastar essa hipótese".

100 "[...] o termo de compromisso constitui negócio jurídico sui generis, regido pelo direito administrativo, bilateral na sua formação e impositivo em seus efeitos, representando assim uma fórmula alternativa para o exercício do poder de polícia de que é titular a CVM. [...] revela traços de negócio jurídico quanto à sua formalização e exteriorização, no que concerne estritamente à fase que o antecede, qual seja a da manifestação da administração pública em face da proposta formulada pelo compromissário, e que, necessariamente, será preliminar à celebração do instrumento, teremos presentes todas as características de ato administrativo típico, denotando, portanto, o caráter misto e singular do instituto". Parecer/CVM/PJU/005, de 10 de março de 1998.

${ }^{101}$ Afastando a hipótese de aplicação das regras disciplinadoras da exceção do contrato não cumprido, por exemplo.

${ }^{102}$ Para MARTINS-COSTA, (2006, p. 99), "[...] é incontroverso que o TCC firmado [...] conforma um acordo, caracterizado (como todos os pactos) (i) estruturalmente, pela presença de dois ou mais contraentes ligados por uma expectativa de confiança, letigimamente amparada em dados fáticos e jurídicos decorrentes de um ato comunicativo, no sentido de que tal arranjo de interesses deve ser cumprido segundo sua função e sua finalidade concreta; e (ii) pela eficácia geradora da vinculabilidade das partes à mantença do que pactuaram".
} 
Adiante seguem apresentados os argumentos desfavoráveis à possibilidade de celebração dos termos de compromisso para, em seguida, virem enumeradas as justificativas da corrente - predominante - questionadora de tais razões, a qual entende ser o instituto compatível com o cenário legal brasileiro.

As próximas linhas analisam se a celebração dos acordos substitutivos é alternativa viável, sob a perspectiva legal, à atuação tradicional da administração, sedimentada na autoridade estatal e na verticalidade ${ }^{103}$ das relações com os particulares, "formalizada em atos administrativos imperativos e unilaterais." 104.

\subsubsection{Argumentos contrários à possibilidade de acordo entre a CVM e administrados}

Não são uniformes as impressões no sentido da legalidade e da possibilidade da celebração de termos de compromisso, tal como previstos na legislação federal brasileira e nos normativos da CVM.

Dois são os principais argumentos adversos à legalidade dos acordos entre a administração pública e os particulares para a extinção de procedimento sancionador, cenário em que se inserem os termos de compromisso celebrados no contexto dos processos administrativos sancionadores conduzidos pela CVM. Ambos decorrem dos chamados "princípios" de direito administrativo ${ }^{105}$.

Considerando que as prerrogativas públicas existam para tutelar o interesse público e para afirmar a supremacia deste sobre o interesse privado, os dois fundamentos para oposição à extinção de processos sancionadores pela adoção de solução consensual entre a Comissão e os participantes do mercado de valores mobiliários seriam (i) a indisponibilidade do interesse público e (ii) a supremacia do interesse público sobre o privado. Sintetiza tais argumentos PALMA (2010, p. 136):

\footnotetext{
"Em termos práticos, as prerrogativas públicas [...] a exemplo da prerrogativa sancionatória - não poderiam deixar de ser utilizadas, ressalvadas exceções pontuais, sob pena de se caracterizar afronta aos princípios da indisponibilidade do interesse público e da supremacia do interesse público sobre o interesse privado".
}

A construção teórica do direito administrativo, assentada sobre alguns pilares, entre os quais a supremacia e indisponibilidade do interesse público (tomados quase como

\footnotetext{
${ }^{103}$ Verticalidade explicada como o posicionamento de desigualdade entre as partes da relação, em oposição à horizontalidade, quando os participantes colocam-se no mesmo plano hierárquico.

${ }^{104}$ PALMA (2010, p. 135).

${ }^{105}$ Sobre o tema confira-se, entre outros, ÁVILA (2012).
} 
verdade absoluta), explica a tradição e o maior destaque conferido às medidas administrativas relacionadas à ação imperativa do administrador. Nessa mesma linha, desenvolvem-se argumentos visando desprestigiar as ferramentas de solução amparadas na consensualidade administrativa, capazes de proporcionar a "satisfação das competências administrativas"

Nesse sentido, o consenso entre a Comissão e os particulares, de que estariam atendidos os seus interesses pelo acordo consignado nos termos de compromisso, poderia ser traduzido como afastamento da supostamente necessária supremacia dos interesses públicos em relação ao dos administrados, teoricamente a eles inafastavelmente subordinados.

Soluções negociadas não seriam, por definição, compatíveis com o chamado interesse público, na medida em que contemplariam também os objetivos dos particulares. A chamada "lógica do consenso [...] se oporia ao princípio da supremacia [...] [e] poderia implicar em prevalência do interesse privado, pois a Administração não terminaria o processo administrativo com ato imperativo e unilateral em que fosse evidenciado o emprego de prerrogativas públicas" ${ }^{, 107}$.

Já para defender a incompatibilidade dos termos de compromisso com o princípio da indisponibilidade do interesse público, outros seriam os fundamentos. Subsidia-se tal argumento no dever da CVM de garantir interesse de terceiros (o "mercado"), do qual não é ela - a CVM - a titular; tampouco é interesse de titularidade do Estado. Seria tal interesse, em sentido lato, a consolidação da parcela projetada por cada agente participante do mercado, diretamente afetado e interessado na manutenção da credibilidade e higidez do próprio mercado.

De tal modo, não seria facultado à Comissão a "livre disposição sobre o interesse público", devendo pautar-se pelas prescrições legais, no sentido de apuração das condutas pela investigação e consequente condução de processo administrativo sancionador. A celebração de acordo seria contrária ao interesse público, pois a administração não poderia dispor do interesse de toda a coletividade. E mais: para negociar com os administrados, deveria ser proprietária do objeto sob o qual transacionaria, além de possuir autonomia para discutir as concessões a serem feitas no âmbito de tal negociação, o que não seria o caso. Em conclusão, “a Administração estaria proibida de celebrar acordos

\footnotetext{
${ }^{106}$ PALMA (2010, p. 136).

${ }^{107}$ PALMA (2010, p. 149).
} 
administrativos na medida em que se encontra vinculada à finalidade legal, razão pela qual também não haveria de se falar em autonomia da vontade na seara administrativa" ${ }^{108}$.

O Professor Marcos Paulo de Almeida Salles, em artigo publicado na Revista de Direito Mercantil n. 108, ainda em $1997^{109}$, posicionou-se assertivamente contra a legalidade dos termos de compromisso entre Comissão de Valores Mobiliários e os administrados sujeitos à fiscalização da Comissão.

O primeiro dos argumentos do autor é que a Lei 9.457/97, ao prever o termo de compromisso, teria causado a extrapolação dos limites da competência do Poder Executivo, potencialmente maculando de inconstitucionalidade a criação do acordo substitutivo $^{110}$.

Questiona o autor, na sequência, a possibilidade de a CVM instaurar processos administrativos de forma legítima, com o escopo habitual (apuração de atividades ou atos ilícitos), "para ao depois considerá-los passíveis de interrupção por acordo entre a autarquia e o indiciado, sem a oitiva do Ministério Público ou a eventual homologação judicial do ato terminativo do procedimento administrativo, apurador da violação à ordem pública"111, e a convivência entre tal tipo de medida e o devido processo legal ${ }^{112}$.

Também preocupava o Professor Salles a possibilidade de o acordo ser - ao menos potencialmente - objeto de disputa judicial, o que o tornaria desprezível, por não reconhecer "à CVM competência homologatória erga omnes" "113. A suposta invasão de competência "própria e indelegável do Poder Judiciário de homologar transações pactuadas pelos contendores" é ventilada em diversas passagens do texto em comento ${ }^{114}$.

\footnotetext{
${ }^{108}$ PALMA (2010, p. 156).

109 “Aspectos da competência do CMN e da CVM no mercado de valores mobiliários”, pp. 101-115.

110 “A Lei 9.457/97 não só procurou alterar dispositivos da Lei 6.404/76, como também inovou no que respeita aos poderes e à competência outorgados à CVM, pela Lei 6.385/76, do que puderam resultar alguns poderes passíveis de argüição de inconstitucionalidade, ao ampliar para além do âmbito do Poder Executivo, a competência exercida por aquela autarquia. Esta preocupação diz respeito à alteração proposta pelo art. $2^{\circ}$ da Lei 9.457/97, com a redação dada aos $\$ \S 5^{\circ}$ e $10^{\circ}$ do art. 11 da Lei $6.385 / 76$, pretendendo atribuir competência à CVM para suspender, em qualquer fase, o procedimento administrativo a que legitimamente der inicio [...]". SALLES (1997, p. 112).

${ }^{111}$ SALLES (1997, p. 112).

112 SALLES (1997, p. 112).

113 "Estará sendo despicienda a norma gerada pela Lei 9.457/97, pelo condão de interromper o procedimento administrativo inquisitório e apenatório, ao mesmo tempo que o referido acordo possa ser objeto de discussão judicial, proposta pelos envolvidos ou pelo Ministério Público. Caso a decisão pelo acordo deva terminativa, não reconhecemos à CVM competência homologatória erga omnes”. SALLES (1997, p. 113).

${ }^{114}$ Com destaque para "Estas e outras questões decorrentes desta pretensão do legislador de suspender o processo administrativo, sem assegurar às partes e aos terceiros a estabilidade jurídica da solução, está, ao mesmo tempo, a revelar uma insegurança jurídica e uma inocuidade decorrente da impossibilidade legal da delegação de competência que se estaria a admitir, se ao referido acordo se atribuir a natureza da transação, ‘inclusive indenizando os prejuízos"”. SALLES (1997, p. 113).
} 
Outras objeções apresentadas no mesmo texto, e antevendo dúvidas que seriam suscitadas na aplicação prática do então novidadeiro instituto, questionam se os termos de compromisso poderiam ser celebrados pela CVM sem sequer a autarquia estar certa da ilicitude da conduta sob investigação ${ }^{115}$, e também o fato de não ser possibilitado a terceiros prejudicados manifestarem-se sobre a indenização a ser oferecida pelo compromitente ${ }^{116}$.

Mais uma questão suscitada pelo mesmo autor é a da "transacionalidade do bem público tutelado pela CVM, cuja preservação jurídica ela mesma deve acometer ao Ministério Público, na defesa dos 'interesses sociais e individuais indisponíveis' que lhe compete" $" 117$, já referido no presente capítulo.

Finalmente, e em complemento ao argumento anterior, o autor afirma não ser possível tropicalizar, de forma adequada, o instituto originado nos Estados Unidos, porque “a ordem pública no Brasil assegura direitos indisponíveis e portanto não passíveis de transação, especialmente na esfera administrativa e onde existam terceiros afetados, como é o caso da previsão indenizatória do texto legal"118.

\subsubsection{Argumentos favoráveis à possibilidade de acordo entre a CVM e administrados}

Apresentados os argumentos contrários - tanto os relacionados à legalidade dos acordos substitutivos firmados entre administração e particulares em um sentido geral, quanto aqueles apresentados pela doutrina especializada especificamente no contexto da adoção do termo de compromisso nos processos administrativos conduzidos pela CVM, delineado para lidar com as questões atinentes ao mercado de valores mobiliários -, cabe expor as razões apresentadas em sentido oposto, favoráveis à legalidade e à adequação de tal ferramenta aos propósitos almejados.

Partindo da experiência da participação da administração pública em arbitragens para resolução de conflitos, especialmente aqueles relacionados ao adimplemento de contratos de concessão, PALMA (2010, pp. 138 e ss.) tratou da experiência já consolidada de atuação administrativa descolada do padrão imperativo, baseado nos já referidos princípios da "indisponibilidade do interesse público" e da

\footnotetext{
${ }^{115}$ Conforme será analisado no item 9.2.1, infra.

${ }^{116}$ Conforme será analisado no item 9.2.1, infra.

${ }^{117}$ SALLES (1997, p. 113).

${ }^{118}$ SALLES (1997, p. 114).
} 
"supremacia do interesse público", para responder se à administração pública seria facultado negociar e transacionar ${ }^{119}$.

A alegada supremacia do interesse público em relação ao interesse particular basilar à rejeição da legalidade e da adequação dos métodos de enforcement que consagram a consensualidade, entre os quais os termos de compromisso ajustados entre a CVM e os participantes do mercado de valores mobiliários - consistiria em "construção teórica, desenvolvida por estudiosos do Direito Administrativo com a finalidade de apresentar uma proposta de sistematização do regime administrativo [...] [e] deve ser compreendido dentro de suas próprias limitações, sem que seja erigido à categoria de dogma $[\ldots]^{\prime 120}$.

Adicionalmente, por não contar com qualquer previsão normativa que o exemplifique ou especifique sua aplicação, as balizas e diretrizes para aplicação seriam questionáveis, "principalmente no que tange à abrangência de seu conteúdo para alcançar as atividades negociais da Administração Pública, além de suscitar dúvidas sobre a existência de tal princípio" $" 121$.

Contestações em relação à aplicação desse princípio na solução de conflitos entre administração e particulares foram construídas, e discussões a respeito de sua compreensão no contexto do sistema jurídico-administrativo indicam o declínio do princípio em análise como elemento central do direito administrativo ${ }^{122}$. É colocada em xeque, pela doutrina administrativista, a validade da estipulação trazida pelo princípio de colocar, de forma absoluta e prévia ao exame dos casos, a prevalência do interesse público em relação aos interesses privados, os quais poderiam vir a merecer preponderância em casos específicos, após exame ${ }^{123}$. Questiona-se também, de forma direta, a própria existência de tal princípio ${ }^{124}$.

Há que se analisar também, para confirmação a respeito da constituição de óbice pelo princípio da supremacia do interesse público face à celebração de acordos pela administração, a "função que desempenha no sistema administrativo"125. Aparentemente, tal princípio teria por missão legitimar a autoridade estatal, fundamentando a conferência

\footnotetext{
${ }^{119}$ Citou a aludida autora a decisão 286/93 do Tribunal de Contas da União (resposta à consulta formulada pelo Ministério de Minas e Energia em relação à adoção de arbitragem para solução de conflito entre a Companhia Hidroelétrica do São Francisco - CHESF e fornecedores), bem como o Agravo de Instrumento $\mathrm{n}$. 52.181/STF (Rel. Min. Bilac Pinto, 1975), proferido no caso Lage, indicados como casos paradigmáticos.

${ }^{120}$ PALMA (2010, pp. 149-150), grifos no original.

121 PALMA (2010, pp. 149-150).

122 PALMA (2010, pp. 150-151).

123 BINENBOJM (2006, pp. 96 e ss.).

124 ÁVILA (1998).

125 PALMA (2010, p. 150).
} 
de prerrogativas especiais ao Estado e a restrição de direitos dos particulares. Assim, todas as prerrogativas públicas seriam derivadas da supremacia do interesse público, que as legitimaria. A doutrina afirma que

\footnotetext{
"Diante deste propósito de legitimação, o princípio da supremacia não poderia ser considerado um óbice à celebração de acordos pela Administração Pública, pois tal princípio cumpre o papel da autoridade estatal, sem trazer em si um critério de solucionamento de conflitos de interesses viável"126.
}

Nesse sentido, mesmo considerando o princípio da supremacia do interesse público existente e aplicável aos termos de compromisso pactuados em processos administrativos sancionadores da CVM, é possível interpretar a adoção de tal mecanismo como meio para efetivar justamente a supremacia do interesse público. Explique-se: a atuação consensual, em decorrência dos efeitos positivos que produz e dos problemas que evita para a administração, "não determina a prevalência do interesse privado em detrimento do interesse público, pelo contrário [...] corresponderia ao processo de satisfação do interesse público concretizado no acordo administrativo" ${ }^{\text {127 }}$.

Conclusivamente em relação ao princípio da supremacia, "(i) o ato consensual pode ele próprio ser considerado o interesse público perseguido pelo Estado e (ii) a funcionalidade do princípio da supremacia corresponde à legitimação de limitação a direitos individuais, bem como de conferência de prerrogativas exorbitantes ao Estado, de forma que essa função não impede a celebração de acordos pela Administração"128.

O segundo apoio à negação da possibilidade de celebração de acordo entre a CVM e os administrados, supostamente decorrente do princípio da indisponibilidade do interesse público, também é passível de razoada contestação.

Cumpre registrar que, principalmente por conta da inexistência de previsão legal a refletir tal princípio, diversas são as acepções que a expressão "indisponibilidade do interesse público" recebe. A consequência direta, aponta-se, é uma "imprecisão conceitual do princípio" ${ }^{29}$ e, por via reflexa, o comprometimento de sua aplicabilidade prática. Com efeito, parece fazer sentido que, inexistindo balizas e critérios concretos, o conceito seja menos prático e aplicável.

\footnotetext{
${ }^{126}$ PALMA (2010, p. 151).

${ }^{127}$ PALMA (2010, p. 151).

${ }^{128}$ PALMA (2010, p. 153).

${ }^{129}$ PALMA (2010, p. 159).
} 
Uma das principais formas de interpretação do conceito de interesse público equipara a indisponibilidade do interesse público à indisponibilidade da finalidade legal ${ }^{130}$, que determinaria ser o interesse público previsto na lei, e não a vontade do gestor público, que sinalizaria o caminho a ser adotado pela administração. Ao agente restaria "tão somente explicitar o interesse público já estabelecido em lei formal e conformar a atividade administrativa de forma a satisfazer o interesse público depreendido do comando legal",131.

Assemelhadamente ao que ocorre no caso da suposta supremacia do interesse público, que pode vir a ser garantida exatamente pela celebração dos acordos substitutivos (entre os quais o termo de compromisso celebrado com a CVM), esta ferramenta pode ser, em certos casos, o mecanismo mais adequado para possibilitar a satisfação do interesse público envolvido ${ }^{132}$, em sentido exatamente oposto ao receio propagado por tal suposta incompatibilidade ${ }^{133}$.

Passemos, pois, à verificação do argumento pelo qual o princípio da indisponibilidade do interesse público vedaria à renúncia total ou parcial dos poderes estatais, tornando inafastáveis as prerrogativas públicas (no caso, o exercício do poder sancionatório tradicional ${ }^{134}$ ) - as quais deveriam ser mandatoriamente empreendidas na atividade administrativa, para atingimento do interesse público.

Por tal renúncia, à “Administração Pública seria defeso (i) renegar peremptoriamente as prerrogativas por meio de declaração em qualquer instrumento jurídico cabível ou (ii) deixar de empregar imotivadamente as prerrogativas quando do desenvolvimento da atividade administrativa, qualquer que seja a sua forma"135. Considerando a não utilização das prerrogativas sancionatórias, em decorrência da adoção dos termos de compromisso, supostamente existiria inobservância à vedação estabelecida.

\footnotetext{
${ }^{130}$ MELLO, (2008, p. 74).

${ }^{131}$ PALMA (2010, p. 159).

132 Não se ataca a indisponibilidade do interesse público, apenas a caracterização da celebração dos termos de compromisso como atentado contra tal princípio. Interesse público não é a punição aos praticantes de condutas à margem da legalidade, mas a preservação do mercado, situada em um plano superior. A respeito confira-se manifestação do corpo de advogados da CVM: "A regulação do mercado e a proteção aos investidores têm por objeto interesses públicos, na medida em que toda a sociedade se vê afetada por este importante segmento da economia nacional. Desse modo, é a CVM entidade governamental responsável pela vigilância e preservação de interesses de ordem pública, os quais, consoante princípio elementar de direito administrativo, são absolutamente indisponíveis." (Parecer/CVM/PJU/005, de 10 de março de 1998).

133 "Ocorre que [...] os acordos administrativos não são antitéticos ao interesse público; por vezes, correspondem à própria expressão do interesse público. Ademais, são os acordos [...] instrumentos para a satisfação das finalidades públicas [...], ao lado dos demais instrumentos compreendidos no regime administrativo, como os atos imperativos e unilaterais". PALMA (2010, pp. 159).

${ }^{134}$ Compreendido pela investigação e apuração das condutas, adoção do trâmite processual sancionatório e, fnalmente, julgamento administrativo (a ser seguido ou não de confirmação judicial).

${ }^{135}$ PALMA (2010, p. 161), grifos no original.
} 
A contestação a tal argumento, que nos parece ser suficiente para superá-lo, fundamenta-se (i) na compreensão de que o interesse público não se resume à sanção ${ }^{136} \mathrm{e}$ apenação do administrado infrator, mas que tal ação do agente público é uma forma de perseguir o interesse público ${ }^{137}$, e (ii) no reconhecimento da outorga de discricionariedade à administração na utilização ou não de tais ferramentas, para alcançar a finalidade a que se vincula $^{138}$ (e, por óbvio, não há contestação em relação à vinculação).

A utilização (emprego útil) das prerrogativas, assimiladas como "instrumentos de tutela do interesse público, garantia da supremacia do interesse público e eficiência administrativa" ${ }^{139}$, deve compreender a opção por exercer uma em detrimento de outra, desde que preservado o propósito determinado no ordenamento e que tais decisões sejam justificadas. Assim, "é plenamente admissível que no caso concreto a Administração deixe de utilizar as prerrogativas públicas ou, ainda, utilize-as de diferentes formas, inclusive de forma integrativa com o administrado" ${ }^{140}$, sendo exatamente essa a racionalidade da celebração de um acordo que encerre processo administrativo sancionador, para preservação e maximização do interesse público ${ }^{141}$.

Há, ainda, outro argumento, construído a partir de norma expressa. Ainda que se entendesse acarretar o acordo administrativo renúncia inadequada do exercício das prerrogativas estatais, de forma a situar os termos de compromisso à margem da atuação adequada dos agentes do Estado, encontraria abrigo nas normas aplicáveis aos processos administrativos, combinada com a permissão legal incluída na Lei 6.385/76.

\footnotetext{
${ }^{136}$ A aplicação da penalidade não é um fim em si mesmo, mas um instrumento a serviço da administração para alcançar os seus fins. O termo de compromisso é outro. Assim, com o termo, "não haveria renúncia da administração pública ao seu poder-dever, apenas o seu diferimento, já que o termo de compromisso não elide, em absoluto, o poder de polícia da CVM [...]". Parecer/CVM/PJU/006, de 10 de março de 1998, Item II - Natureza jurídica do termo de compromisso (consent decree). À mesma conclusão chegou PALMA (2010, pp. 162): “[...] um órgão ou ente da Administração Pública pode deixar de aplicar determinada sanção administrativa ou, ainda, findar consensualmente o processo sancionador na medida em que a potestade sancionadora é meramente instrumental às finalidades públicas. Tais finalidades públicas, onde não está compreendida a suposta finalidade repressora do Estado, podem ser satisfeitas de diversas maneiras pelo Poder Público, por meio desde mecanismos notadamente imperativos até mecanismos outros consensuais $[\ldots]$...

${ }^{37} \mathrm{O}$ interesse público a ser preservado no caso do mercado de valores mobiliários pode ser entendido como aqueles os objetivos da CVM, indicados no artigo $4^{\circ}$ da Lei 6.385/76.

${ }^{138}$ EIZIRIK et. al. (2008, p. 357) sintetizam que o termo de compromisso é "instrumento que lhe permite [à $\mathrm{CVM}$ ] perseguir o interesse público de forma rápida e eficaz, nos casos em que, em seu entendimento, a eventual continuidade do processo não traria qualquer benefício ao desenvolvimento do mercado."

${ }^{139}$ PALMA (2010, p. 162).

${ }^{140}$ PALMA (2010, p. 162).

${ }^{141}$ Exatamente à mesma conclusão chegou CUEVA (2007, p. 304), no entender de quem não é adequada a “objeção de que tais instrumentos [acordos substitutivos] pudessem caracterizar a renúncia, pela Administração, de um direito indisponível, posto que constituem meios rápidos e eficientes para alcançar a cessação da irregularidade e/ou a indenização do prejuízo causado".
} 
O segundo inciso do parágrafo único do artigo $2^{\circ}$ da Lei $9.784 / 99^{142}$, prevê a hipótese de "autorização legal" como exceção à vedação à renúncia de poderes, no âmbito do processo administrativo federal. Claramente o parágrafo $5^{\circ}$ do artigo 11 da Lei $6.385 / 76^{143}$ desempenha o papel de autorizador à renúncia do exercício do poder sancionatório da Comissão, ao oferecer medida sucedânea, se não em sua natureza, mas na sua função.

A necessidade de previsão legal, condição precedente à adoção dos termos de compromisso no contexto da disciplina do mercado de valores mobiliários ${ }^{144}$, encontra então reforço em um passo lógico anterior (ainda que mais recente, pois a Lei 9.784/99 foi sancionada vinte meses depois da Lei 9.457/97), na previsão abrangente e que expressamente prevê o não exercício de prerrogativas da administração, amparado em dispositivos legais vigentes.

Registre-se também a existência de argumentação ancorada em princípios constitucionais (os quais foram replicados na Lei 9.784/99) para defesa da legalidade e pertinência da adoção de acordos entre a CVM e os agentes do mercado. Na visão de SOUZA (2010, p. 101)

\footnotetext{
“A justificativa para a utilização de meios consensuais de solução de conflitos assenta-se em princípios constitucionais, expressos ou não, que devem nortear a atuação da Administração Pública, tais como o princípio da eficiência, o princípio da proporcionalidade, o princípio da razoabilidade, o princípio da razoável duração do processo administrativo, bem assim o princípio democrático".
}

Por fim, como último tema do presente tópico, será verificada a pertinência de cada um dos pontos centrais suscitados pelo Professor Salles, no item imediatamente anterior, considerando as experiências acumuladas desde as impressões iniciais expostas enfaticamente em 1997.

$\mathrm{O}$ primeiro argumento, relacionado à suposta extrapolação dos limites da competência do Poder Executivo, potencialmente maculando de inconstitucionalidade a

\footnotetext{
142 “Art. $2^{\circ}$ A Administração Pública obedecerá, dentre outros, aos princípios da legalidade, finalidade, motivação, razoabilidade, proporcionalidade, moralidade, ampla defesa, contraditório, segurança jurídica, interesse público e eficiência. Parágrafo único. Nos processos administrativos serão observados, entre outros, os critérios de: [...] II - atendimento a fins de interesse geral, vedada a renúncia total ou parcial de poderes ou competências, salvo autorização em lei; [...]”. (sem grifos no original).

${ }^{143}$ Estudado de forma mais aprofundada no item 4.3, infra.

${ }^{144}$ Como referido no item 2.1 acima, a Comissão apenas poderia servir-se dos termos de compromisso após previsão legal autorizadora, nascida com a Lei 9.457/97. Nesse sentido, ARAGÃO e SANTOS (1979, p. 14): “[...] o poder de punir é, salvo disposição expressa da lei, absolutamente vinculante, não se podendo falar a tal propósito em juízo de oportunidade e conveniência, elementos em que se resolve, como é notório, a atuação discricionária da administração”.
} 
criação do acordo substitutivo pela Lei 9.457/97, parece não ter ecoado nos tribunais. Não há registro de discussão a respeito da legalidade da regra instituída. Não há, aliás, qualquer discussão nos tribunais superiores a respeito da legalidade ou inconstitucionalidade do termo de compromisso no contexto do mercado de valores mobiliários, o que, em parte, é explicado pelo aprimoramento da legislação pelas alterações posteriores ${ }^{145}$, pela suficiente disciplina normativa apresentada ao mercado pela Comissão e pela assimilação, pelos particulares, do funcionamento da ferramenta.

O segundo argumento apresentado no texto de 1997 atacava a possibilidade de a Comissão instaurar processos administrativos e, de modo supostamente incompatível, determinar a sua interrupção (suspensão e arquivamento, o último após adimplemento total do acordo pelo administrado), sem a oitiva do Ministério Público ou homologação judicial do ato, o que atentaria contra o devido processo legal. Tendo em vista que o processo administrativo é conduzido pela CVM de modo integral, sem homologação judicial das decisões e demais atos processuais, e que a Procuradoria Federal Especializada desempenha o papel de controle interno da legalidade administrativa dos atos praticados pela $\mathrm{CVM}^{146}$, inclusive examinando a legalidade das propostas de termo de compromisso $\operatorname{apresentadas}^{147}$, parece inadequado vincular a adoção de termos de compromisso à aprovação externa, seja do Judiciário, seja do "parquet".

Com relação ao problema advindo da suposta inexistência de "competência homologatória erga omnes da CVM", que potencialmente conduziria a disputas judiciais envolvendo os termos de compromisso, e acabaria tornando-o desprezível, parece que a resposta guarda conexão com a separação das esferas em que infrações podem gerar efeitos $^{148}$, especificamente entre a seara administrativa e a civil. Com o arquivamento decorrente da satisfação das obrigações contraídas perante a CVM (e eventuais terceiros) pela celebração do termo de compromisso, o investigado deixa de ser punível pela ação compromissada na esfera administrativa. Como resultado, evita-se julgamento e potencial decisão condenatória pela CVM em relação à conduta, mas sem que se operem quaisquer efeitos contra terceiros eventualmente prejudicados. Inclusive, em casos de compromisso

\footnotetext{
145 Evitando, por exemplo, as discussões havidas a respeito da existência de um direito subjetivo do administrado à celebração de um acordo, como houve no âmbito concorrencial, conforme retratado no item 4.5 , infra.

${ }^{146}$ Conforme disciplinado no artigo 13 do Anexo I ao Decreto n. 6.382, de 27 de fevereiro de 2008, que trata da estrutura regimental da Comissão de Valores Mobiliários, combinado com o artigo 11, V, da Lei Complementar 73, de 10 de fevereiro de 1993 (Lei Orgânica da Advocacia Geral da União).

${ }^{147}$ Sobre o tema, item 9.2.3 infra.

${ }^{148}$ Objeto do item 13.1 infra.
} 
de indenização a terceiros, caso os lesados entendam ser insuficiente a reparação definida no acordo administrativo, podem pleitear complementação em juízo ${ }^{149}$.

O penúltimo argumento a fundamentar o receio da adoção dos termos de compromisso pela CVM seria a inadequação da aceitação de propostas de acordo apresentada por investigados, sem a CVM sequer estar certa da ilicitude da conduta sob análise, o qual merece destaque. De fato, não parece ser apropriado aceitar proposta de acordo e extinguir investigações sem que se tenha ao menos bases sólidas a respeito da infração a que a conduta potencialmente corresponda, bem como de sua extensão. Tal argumento foi incorporado por diversos estudiosos do tema, e representa ponto de atenção a ser considerado pela Comissão ${ }^{150}$.

Por fim, a impossibilidade de terceiros prejudicados apresentarem manifestação sobre a indenização a ser oferecida pelo compromitente, apontada pelo Professor Salles como mais uma falha na disciplina, foi contemplada pela Comissão, em sua Deliberação CVM n. 390, de 8 de maio de 2001 (“D. CVM 390/01”), especificamente nos artigos 10 e $11^{151}$.

Considerando o apresentado, é possível concluir no sentido oposto ao argumento suscitado no princípio: existe, sim, maior chance de contentamento do interesse público caso ao administrador seja facultado alcançar a ultimação dos processos administrativos sancionadores pela celebração dos termos de compromisso entre a CVM e os supostos infratores ${ }^{152}$. Sobretudo, em virtude dos seus efeitos (ex ante e ex post), adiante

\footnotetext{
${ }^{149}$ Conforme descrito no item 9.2.2.1 infra.

${ }^{150}$ Motivo pelo qual a tal tema dedicou-se parte do item 9.2.1.

${ }^{151}$ Para análise da Deliberação e procedimentos, ver item 9 infra.

152 “O termo de compromisso cria, portanto, ambiente propício (em tese) à consecução do objetivo precípuo da atividade administrativa - o bem comum da coletividade administrada - sendo esta, no nosso entender, a função mediata do instituto, e que se encontra em consonância com os princípios e atribuições previstos nos artigos $4^{\circ}$ e $8^{\circ}$ da Lei $n^{\circ}$ 6.385/76". Parecer/CVM/PJU/006, de 10 de março de 1998, Item II - Natureza jurídica do termo de compromisso (consent decree).
} 
analisados ${ }^{153}$. Posicionamentos alinhados a tal ideia podem ser encontrados na doutrina ${ }^{154} \mathrm{e}$ em julgamentos administrativos conduzidos pela Diretoria Colegiada da Comissão ${ }^{155}$.

\subsection{Os requisitos do parágrafo $5^{\circ}$ do artigo 11 da Lei $6.385 / 76$}

O presente tópico expõe os requisitos legais essenciais à suspensão do processo administrativo. Entende-se que esses requisitos são da essência do termo de compromisso por serem condições expressamente previstas no texto legal introdutor do instrumento, sendo tais requisitos aplicáveis para termos versando sobre qualquer conduta, seja ela exigida por disposições legais ou por normativos da Comissão que especificam os comportamentos que devem ser adotados pelos agentes.

A regra constante do parágrafo $5^{\circ}$ do artigo 11 da Lei 6.385/76 claramente limita a ação da Comissão de Valores Mobiliários: para que possa ser determinada a suspensão de procedimento administrativo em curso, o acusado deve propor a celebração do termo obrigando-se a satisfazer, no mínimo, as exigências listadas no referido dispositivo legal. Mesmo que sejam propostas diversas outras obrigações, ainda que representem benefícios consideráveis ao interesse público tutelado pela Comissão, o acordo substitutivo não poderá ser firmado, ao menos dentro dos limites da forma legal, caso não sejam atendidas as imposições previstas nos incisos do parágrafo $5^{\circ}$ do artigo 11 da Lei $6.385 / 76^{156}$.

Tais requisitos demandam, do compromitente, a interrupção da conduta "considerada ilícita" pela CVM e a correção de "irregularidades apontadas", com ressarcimento de prejuízos, configurando balizas mínimas à celebração dos termos de compromisso por essa autarquia, as quais limitam a discricionariedade já apresentada.

\footnotetext{
${ }^{153}$ Item 6.1 abaixo.

154 “A outorga da possibilidade de transacionar, conferida pelo legislador à CVM, não implica em alienação ou renúncia dos interesses dos investidores do mercado de capitais. Ao contrário, a assinatura do termo de compromisso constitui meio rápido e eficiente de alcançar a sua realização, através da suspensão da prática de atos que poderiam ser tidos como ilícitos pela CVM e/ou indenização das partes eventualmente prejudicadas. O termo de compromisso firmado entre a parte que está sob investigação e a CVM se afigura mais consetânea com a tutela do interesse dos investidores do mercado de capitais do que seria a continuidade do processo administrativo.” EIZIRIK (1998, Regime..., p. 102) No mesmo sentido, DUBEUX (2006, p. 101): "Não se trata, portanto, de abdicar do interesse público, mas sim de persegui-lo de forma mais ágil e eficiente".

155 "Não se trata, evidentemente, de tolerar o ilícito, mas sim de permitir à entidade reguladora identificar o momento em que a resposta regulatória já se apresentou suficiente para o bom desenvolvimento do mercado". Voto do Diretor Sergio Weguelin, Processo CVM RJ 2001/4652, julgado em 22.03.2005.

${ }^{156}$ A saber: "[...] I - cessar a prática de atividades ou atos considerados ilícitos pela Comissão de Valores Mobiliários; e II - corrigir as irregularidades apontadas, inclusive indenizando os prejuízos”.
} 
Pelo texto original do PL $1.564^{157}$, haveria um terceiro inciso, determinando que o compromitente deveria, em adição às determinações dos dois mantidos, "consentir na aplicação de penalidade"158. A exigência, suprimida no substitutivo apresentado pelo Deputado Luiz Carlos Hauly, faria com que existisse apenação mesmo que o processo fosse encerrado por termo de compromisso.

A eliminação do terceiro inciso, acima referido, deu-se sob o argumento de que seriam "suficientes as obrigações previstas nos outros dois incisos do parágrafo"159. De fato, a manutenção do texto suprimido do projeto seria passível de questionamentos, sendo razoável argumentar a incompatibilidade com o sistema delineado. Sobretudo se considerada a regra do parágrafo $6^{\circ}$, pela qual inexiste "confissão quanto à matéria de fato" ou "reconhecimento de ilicitude da conduta analisada"160, permitindo ser considerada ilógica a situação de aplicação de penalidade - com a qual o signatário do termo deveria obrigatoriamente consentir - sem sequer ser analisada a pertinência da acusação, materialidade e demais elementos, como a correta capitulação da conduta supostamente infracional $^{161}$.

Outro possível argumento contrário à regra excluída da redação final do parágrafo $5^{\circ}$ do artigo 11 da Lei 6.385/76 atacaria a coexistência da regra abolida com a previsão do parágrafo $8^{\circ}$ do mesmo enunciado. Caso o compromissário "concordasse com a aplicação da penalidade", exemplificativamente arcando com multa (ou com a imposição de pena restritiva de direitos) e, por inadimplemento de alguma outra cláusula do termo inclusive por desatenção a alguma obrigação não essencial como, por exemplo, a apresentação tempestiva de comprovante de pagamento de multa -, poderia ser retomado o processo administrativo anteriormente suspenso, para "aplicação das penalidades cabíveis"162. A dinâmica legal do termo de compromisso abrigaria, então, uma potencial

\footnotetext{
157 Abordado no item 4.

158 Conforme texto do PL 1.564, publicado na edição de 10 de janeiro de 1997 do Diário da Câmara dos Deputados, p. 893.

159 Voto do relator do PL 1.564/96, Luiz Carlos Hauly, publicado na edição de 12 de dezembro de 1996 do Diário da Câmara dos Deputados, p. 32.958 e reproduzido na Revista de Direito Mercantil n. 105 (1997), p. 172.

${ }^{160}$ Tratada no item 4.4 infra.

${ }^{161}$ Sobre o tema, EIZIRIK (1998, p. 262) ensina que “[...] a redação do dispositivo, ora examinado, tal como elaborada no 'Projeto Kandir', permitiria conclui-se que, além de cessar a prática de atividades que pudessem ser consideradas ilícitas pela CVM e de corrigir as eventuais irregularidades, indenizando terceiros prejudicados em razão dessa atuação, o acusado deveria consentir na aplicação da penalidade. [...] é lógico que seria absolutamente incoerente a imputação de pena ao acusado no momento da assinatura do termo de compromisso, já que este tem natureza de acordo, não tendo restado provado, naquele momento, o cometimento de ilícito algum".

${ }^{162}$ A retomada do procedimento em caso de inadimplemento, inclusive com crítica à redação ora referida, será tratada no item 9.2.11, infra.
} 
dupla apenação pela CVM em razão de uma mesma conduta: uma consentida, no momento da celebração do acordo, e outra imposta, ao final do processo administrativo sancionador retomado, caso a decisão fosse condenatória.

É possível supor que, caso o terceiro inciso fosse preservado ao final do processo legislativo, maiores seriam os problemas e polêmicas na aplicação dos termos de compromisso, causando natural redução de interesse dos agentes do mercado na utilização da ferramenta.

Antes do exame de cada uma das exigências legais vigentes, cumpre registrar observação feita por EIZIRIK, ainda em 1998, de que as obrigações essenciais deveriam ser alternativas, a exemplo da redação prevista no anteprojeto elaborado pela $\mathrm{CVM}^{163}$, e que o texto vigente deveria ser objeto de ajuste ${ }^{164}$. Trata-se de uma alternativa regulatória ao regramento atual, a qual inclusive poderia trazer resultados interessantes, concedendo à autoridade administrativa flexibilidade ainda maior na negociação do conteúdo do acordo. Todavia, não foi contemplada pelo legislador (a quem inclusive concedeu-se oportunidades para rever seu posicionamento, considerando as diversas alterações operadas na Lei 6.385/76 desde a publicação da Lei 9.457/97 ${ }^{165}$ ).

Ainda, cabe referir que, ao receber uma proposta de termo de compromisso que não satisfaça os requisitos essenciais do parágrafo $5^{\circ}$ do artigo 11 , após ser informado da pendência pela Procuradoria Federal Especializada, o Comitê, caso entenda ser possível emenda à proposta para satisfação da exigência legal, apresenta sugestões ao proponente, que pode aceitá-las, reformulando a proposta anterior, ou ignorar tais indicações.

\footnotetext{
${ }^{163}$ Conforme passagem transcrita no item 3.2, o anteprojeto previa alternatividade nas medidas a serem adotadas pelo compromissário.

164 "A redação do inciso II do $\$ 5^{\circ}$ do art. 11 da lei merece, igualmente, reparo, uma vez que não é indispensável a indenização dos prejuízos para que se firme o Termo de Compromisso. Embora a lei utilize a conjunção 'e' na redação dos incisos I e II do seu $\$ 5^{\circ}$, o legislador objetivou, na verdade, facultar ao indiciado ou acusado a possibilidade de cessar a prática de atos ou atividades que poderiam vir a ser consideradas, eventualmente, ilícitas pela CVM ou corrigir as irregularidades apontadas, indenizando prejuízos, se forem preenchidos os seguintes requisitos: a) se houver, obviamente, prejuízo, pois não há responsabilidade sem dano; b) se os prejuízos puderem ser quantificados; c) se os prejudicados puderem ser identificados ou identificáveis, isto é, se puder ser atribuído a cada prejudicado um valor a ser pago a título de indenização". EIZIRIK (1998, Regime..., p. 103). Destaque no original.

${ }^{165}$ Diversos artigos da Lei $6.385 / 76$ foram alterados, incluídos ou revogados por outros diplomas legais em 1999, 2001, 2002, 2007 e 2011
} 


\subsubsection{Cessação da prática considerada ilícita}

O primeiro tema obrigatoriamente contemplado em todas as propostas de termo de compromisso apresentadas à Comissão é a imediata interrupção da realização dos atos ou da atividade motivadores da investigação ou do processo administrativo ${ }^{166}$.

O objetivo imediato de tal exigência parece evidente: interromper condutas potencialmente ${ }^{167}$ ilícitas, ao passo que seu escopo mediato é impedir novos prejuízos e evitar que danos eventualmente causados sejam agravados, o que poderia vir a ocorrer em decorrência da manutenção da conduta, até finalmente ser julgada lesiva (a terceiros identificáveis ou ao mercado). Parece ser pressuposto lógico para tanto que a atividade sobre a qual versa o compromisso seja de natureza contínua, ou os atos objeto do compromisso venham sendo praticados de forma reiterada, e possam vir a ser executados novamente, em momento futuro ${ }^{168}$.

\footnotetext{
${ }^{166}$ Em Portugal, pelo artigo 413 do Código dos Valores Mobiliários (Aprovado pelo Decreto-Lei n. ${ }^{\circ} 486$, de 13 de novembro de 1999), há a possibilidade de a Comissão dos Mercados de Valores Mobiliários, ao iniciar um processo administrativo por infração às normas do mercado que não tenha resultado em prejuízo a investidores ou ao mercado, enviar advertência ao infrator para que ele sane a irregularidade. Caso atenda o pedido, o processo é arquivado e a "a advertência torna-se definitiva, como decisão condenatória, não podendo o mesmo facto voltar a ser apreciado como contra-ordenação". Outro mecanismo previsto no ordenamento português (artigo 415 do mesmo Código) consiste na suspensão da sanção. Pela suspensão da sanção, a CMVM pode suspender a execução da sanção administrativa desde que o administrado cumpra obrigações determinadas, "designadamente as consideradas necessárias para a regularização de situações ilegais, à reparação de danos ou à prevenção de perigos para o mercado de valores mobiliários ou de outros instrumentos financeiros ou para os investidores". Passado o prazo da suspensão, que é fixado pela autoridade entre dois e cinco anos, sem que o acusado pratique qualquer ilícito (criminal e administrativo) previsto na legislação do mercado de valores mobiliários, "fica a condenação sem efeito, procedendo-se, no caso contrário, à execução da sanção aplicada". Referindo-se a ambas as ferramentas, PINTO (2000, p. 387) comenta que "Trata-se de mecanismos importantes que introduzem simplificação e celeridade processual em casos que apresentam, em concreto, pouca gravidade e que, por isso, não justificam que quer o arguido, quer a autoridade administrativa sigam toda a tramitação comum para obter uma decisão final". Breves comentários também são ofertados por PINTO e REIS (2001, p. 13) e CLUNY (2007, pp.72-73).

${ }^{167}$ Cumpre relembrar ser da própria lógica do instituto que a celebração dos acordos ocorra antes da conclusão da apuração da infração (por isso referida como "suposta infração"), e a razoabilidade na conclusão de termos de compromisso antes mesmo de ser quantificada ou confirmada a lesão a direito de terceiro, para que a ação ou omissão potencialmente causadora seja interrompida.

${ }^{168}$ Exemplo da satisfação de tal requisto encontra-se na análise feita pelo Comitê de Termo de Compromisso, no seu Parecer em relação à proposta apresentada no âmbito dos Processos Administrativos Sancionadores CVM RJ 2007/2901 e RJ 2007/10229: "No caso em tela, verifica-se o cumprimento dos requisitos insertos no inciso I e parte inicial do inciso II do $\S 5^{\circ}$ do art. 11 da Lei n. ${ }^{\circ} 6.385 / 76$ (cessação da prática do ato considerado ilícito pela CVM e correção das irregularidades), já que a [Acusada], após instada pela SIN, sanou com celeridade as irregularidades detectadas no processo de registro do Fundo $[A]$ e do Fundo $[B]$, sendo de se ressaltar que não há indícios de reiteração da conduta em outro fundo sob sua administração, corroborando a afirmação da proponente de que passou a adotar 'as medidas necessárias para mudar a sistemática até então vigente e substituí-la pela recomendada pela CVM"'. Tal proposta foi aceita pelo Colegiado da Comissão, sendo inclusive registrado na ata da reunião do Colegiado que aprovou o acordo o perfeito atendimento à cessação da prática suspeita de ilicitude: "O Comitê observou que a [Acusada], após instada pela SIN, sanou com celeridade as irregularidades detectadas nos processos de registro do Fundo $[A]$ e do Fundo $[B]$, sendo de se ressaltar que não há indícios de reiteração da conduta em outro fundo sob sua administração". (Decisão do Colegiado em 13 de novembro de 2007).
} 
Por consequência, em termos de compromisso versando sobre atos ou condutas situados estritamente em momento pretérito ao da sua proposição, tal requisito parece ser inócuo, sendo impossível o seu "atendimento". A Comissão (seja por seu Comitê de Termo de Compromisso, seja pelo Colegiado ou pela Procuradoria Federal Especializada), na análise de propostas de acordo tratando de condutas de tal espécie (não continuadas ou já encerradas), usualmente indica já ter sido atendido ${ }^{169}$, observado ${ }^{170}$ ou preenchido ${ }^{171} \mathrm{o}$ requisito do inciso I, "não se podendo falar de cessação de prática já encerrada e não continuada" ${ }^{\prime 172}$.

Em outras oportunidades, a Comissão já afirmou que "não há que se falar em cessação [...], tendo em vista que o fato [...] teria ocorrido em momento passado determinado" ${ }^{\# 173}$, ou declarou apenas a inaplicabilidade da norma exigidora da cessação ${ }^{174}$. Ideia assemelhada é apresentada em análises empreendidas por especialistas no tema ${ }^{175}$.

Por oportuno, vale comentário em relação às formas de cessação da conduta sob investigação, com exemplificação fundamentada em casos.

A “prática de atividades ou atos" referida no inciso I do parágrafo $5^{\circ}$ do artigo 11 da Lei 6.385/76 - e que deve ser interrompida, por força do mesmo enunciado legal pode ser uma ação (a realização de determinada operação em desrespeito às normas, como a negociação de valores mobiliários por detentor de informação privilegiada) ou omissão

\footnotetext{
${ }^{169}$ Parecer do Comitê de Termo de Compromisso a respeito de proposta apresentada no âmbito do Processo Administrativo Sancionador CVM RJ 2007/1854, datado de 20 de maio de 2008.

170 "No que tange ao primeiro requisito legal para a celebração de termo de compromisso, tem-se que as irregularidades específicas e que ora estão sendo imputadas já ocorreram, não sendo possível cessar o que já não existe. Assim, entendo plenamente observado, in casu, o disposto no art. $11, \S 5^{\circ}$, inciso I, da Lei $\mathrm{n}^{\circ}$ 6.385/76". Entedimento do Procurador Federal José Eduardo Guimarães Barros, exposto no MEMO/PFECVM/GJU-2/N. $16 / 09$.

${ }^{171}$ Processo Administrativo Sancionador CVM 10/01, Rel. Diretor Wladimiri Castelo Branco, j. 11 de maio de 2004, citado por EIZIRIK et. al. (2008, p. 343).

${ }^{172}$ Parecer do Comitê de Termo de Compromisso a respeito de proposta apresentada no âmbito do Processo Administrativo Sancionador CVM RJ 2009/5327, datado de 7 de março de 2012.

${ }^{173}$ Parecer do Comitê de Termo de Compromisso a respeito de proposta apresentada no âmbito do Processo Administrativo Sancionador CVM SP 2006/0168, datado de 6 de novembro de 2007.

174 "Sobre a incidência da norma inserta no inciso I da Deliberação CVM 390/01, que impõe a cessação da prática irregular, - considerando-se a natureza da execução dos referidos ilícitos administrativos, comissivos e omissivos, de resultado jurídico e exaurimento imediatos; e relativos a determinado período de tempo no passado - , não há que se aplicá-la, vez que não haveria, hoje, prática a ser cessada". Parecer do Comitê de Termo de Compromisso a respeito de proposta apresentada no âmbito do Processo Administrativo Sancionador CVM 16/2008, datado de 28 de agosto de 2012.

175 "Especificamente quanto ao primeiro requisito legal, parece relevante destacar o uníssono entendimento da CVM, respaldado pela visão de sua Procuradoria Federal Especializada (PFE-CVM) - que tem o dever de se manifestar, conforme o disposto no $\$ 5^{\circ}$ do art. $7^{\circ}$ da Deliberação CVM nº390/01, sobre a legalidade da proposta de termo de compromisso apresentada e cujo titular integra, sem direito de voto, o adiante mencionado Comitê de Termo de Compromisso - no sentido de que sempre que as irregularidades imputadas tiverem ocorrido em momento anterior e não se tratar de ilícito de natureza continuada, ou não houver os autos quaisquer indicativos de continuidade das práticas apontadas como irregulares, considerar-se-á cumprido o requisito legal, na exata medida em que não é possível cessar o que já não existe". WELLISCH e SANTOS (2009, p. 5).
} 
(por ex., desatenção às normas que obrigam emissores de valores mobiliários à divulgação de informações periódicas ${ }^{176}$, ou adoção de procedimentos específicos - como a correta identificação de clientes por sociedades corretoras de valores mobiliários). Assim, naturalmente, a cessação da ação corresponde à sua imediata interrupção, ao passo que a cessação de uma omissão será a imediata adoção do comportamento adequado. Destarte, a cessação prevista na lei pode ser caracterizada pela ação positiva do candidato a compromitente (no caso de omissão).

A inobservância da exigência de cessação da conduta ${ }^{177}$ sob suspeita acarreta, de acordo com a correta interpretação da Procuradoria Federal Especializada ${ }^{178}$ e do Comitê de Termo de Compromisso, obstáculo intransponível à aceitação da proposta apresentada pelo administrado. Ao ser verificado o não atendimento do requisito, concluise - invariavelmente - pela impossibilidade de aceitação do acordo, como no caso do termo proposto para suspensão e extinção do Processo Administrativo Sancionador CVM RJ 2006/5822 $2^{179}$.

Atualmente, a "cessação da conduta" não tem sido objeto do termo de compromisso propriamente dito (documento firmado pelo acusado e pela CVM), não sendo possível encontrar nos acordos assinados recentemente o compromisso expresso de cessação da conduta. Com efeito, a cessação propriamente dita tem sido exigida previamente à assinatura do acordo, como requisito para manifestação positiva da Procuradoria Federal Especializada, numa espécie de "exame de admissibilidade", usualmente referido no Parecer do Comitê de Termo de Compromisso.

\footnotetext{
${ }^{176}$ Como no caso da proposta de termo de compromisso apresentada no contexto do Processo Administrativo Sancionador CVM RJ 2011/9482, instaurado para apurar conduta de diretor de relações com investidores de companhia aberta, em razão do atraso ou do não envio de formulários de informações trimestrais, demonstrações financeiras anuais, formulário cadastral, formulário de referência e documentos relacionados às assembleias da companhia. Ainda que o investigado oferecesse à CVM pagamento de valor alinhado aos compromissos celebrados à época (conforme entendimento do Comitê de Termo de Compromisso apresentado no parecer de 11 de janeiro de 2012), apenas quando da apresentação do último dos documentos em atraso foi confirmada a inexistência de óbice legal à celebração do acordo, manifestando-se o Comitê ter ocorrido "a regularização da situação da [Acusada] perante a CVM, em atendimento aos requisitos legais necessários à celebração do Termo de Compromisso". (Parecer do Comitê de Termo de Compromisso apresentado em 11 de janeiro de 2012).

${ }_{177}$ Parece-nos, considerando o parágrafo anterior, que "cessação da conduta" afigura-se mais adequado do que a "cessação da prática de atos ou atividades", exatamente por incluir as omissões.

${ }^{178}$ Conforme item 9.2.3, infra.

179 Conforme é possível inferir de trecho do parecer apresentado pelo Comitê de Termo de Compromisso datado de 25 de outubro de 2006: "Ocorre que, consoante disposto acima, os procedimentos elencados no inciso I do art. 13 da Instrução CVM no 202/93 continuam não sendo observados pela aludida DRI, de sorte que não há que se falar na cessação da prática da atividade considerada ilícita pela CVM, conforme requer o inciso I do $\$ 5^{\circ}$ do art. 11 da Lei $n^{\circ}$ 6.385/76, para fins de celebração de Termo de Compromisso com esta Autarquia. Nesse sentido, inclusive, manifestou-se a PFE ao examinar os aspectos legais da proposta apresentada", (sem grifos no original).
} 
Assim, ainda antes da assinatura do acordo pelas partes, a conduta já é interrompida ou ajustada ${ }^{180}$, conforme o caso ${ }^{181}$. Há, ainda, registro de caso em que o Comitê de Termo de Compromisso propôs ao Colegiado a aceitação de proposta de acordo substitutivo, condicionada à regularização das pendências até a data da reunião da Diretoria Colegiada para apreciação da proposta $^{182}$. Em tal situação, por não ter ocorrido a "cessação da atividade", na forma de regularização de registro de companhia aberta, o Colegiado recusou a proposta, com base exatamente no mesmo fundamento ${ }^{183}$.

Em tempos passados, era possível encontrar casos em que o ajuste da conduta era inicialmente pactuado no acordo escrito, e só então implementado ${ }^{184}$. Dessa forma, o procedimento era mais fiel à legislação, segundo a qual a obrigação de cessação da prática

\footnotetext{
${ }^{180}$ No caso de ausência de publicações obrigatórias, por exemplo, a conduta de omissão é interrompida, dando lugar ao adimplemento das obrigações, ainda que tardiamente.

${ }^{181}$ Vale também transcrever trecho do MEMO N. 30/2012/GJU-1/PFE-CVM/PGF/AGU, citado no Parecer do Comitê de Termo de Compromisso exarado em 30 de maio de 2012, após apreciação da proposta apresentada pelos acusados no Processo Administrativo Sancionador CVM SP 2011/99, pelo qual a Procuradoria Federal Especializada inclusive solicita averiguação pela área técnica da Comissão, para apuração a respeito da concretização da cessação das práticas, como requisito para confirmar a legalidade da proposta apresentada pelos administrados: “[...] para fins de que se comprove a efetiva cessação das práticas consideradas ilícitas, parece recomendável que a Área Técnica verifique se os atos suspeitos foram efetivamente cessados (condição constante do inciso I), bem como, se condutas adotadas pela empresa, acima mencionadas, mostraram-se aptas a sanar as irregularidades apontadas na peça acusatória (requisito previsto no inciso II). Feito isto e, caso se entenda que, de fato, não há conduta a ser cessada, assim como, as irregularidades estão sanadas, inexiste óbice jurídico quanto à aceitação do Termo de Compromisso em apreço".

182 "No caso em tela, em que pese a existência, neste momento, de documentos pendentes de entrega junto a esta CVM, o Comitê se mostra favorável à celebração do termo de compromisso, condicionando-se a aprovação da proposta à efetiva regularização da situação da companhia até a data da reunião do Colegiado em que a mesma for apreciada, o que, a seu ver, afigura-se possível e razoável. [...] Em face do acima exposto, o Comitê de Termo de Compromisso propõe ao Colegiado da CVM a aceitação da proposta de Termo de Compromisso apresentada por [Acusada], desde que a [Companhia] tenha seu registro de companhia aberta junto à CVM regularizado até a data de reunião do Colegiado". Parecer do Comitê de Termo de Compromisso, datado de 7 de março de 2012.

183 “O Superintendente Geral informou que o registro da Companhia junto à CVM remanesce desatualizado, tendo em vista a não apresentação de todos os documentos em atraso. Dessa forma, o Colegiado deliberou a rejeição da nova proposta de termo de compromisso apresentada pela [Acusada]". Ata da Reunião do Colegiado realizada em 3 de abril de 2012.

${ }^{184}$ Como exemplo desse tipo de sistemática é possível apontar o termo de compromisso firmado para suspensão e posterior arquivamento do Inquérito Administrativo CVM 2001/0281, no qual as obrigações assumidas incluíam, ao lado do pagamento à Comissão, "refazer as demonstrações financeiras da Companhia [...] referentes aos exercícios de 1998, 1999 e 2000 e elaborar as demonstrações financeiras relativas ao exercício de 2001, com as correções determinadas pela SEP [...] estornando os efeitos da reavaliação de ativos aprovada pela Assembléia Geral, realizada em 21 de setembro de 1998, das aludidas demonstrações contábeis; publicar as demonstrações financeiras relativas ao exercício de 2001, no prazo do artigo 133 , § $3^{\circ}$, da Lei $n^{\circ}$ 6.404/76, onde aparecerão também os dados referentes aos exercícios de 1998, 1999 e 2000, fazendo constar de tal publicação nota explicativa, antes das demais notas, informando que as demonstrações relativas aos exercícios de 1998, 1999 e 2000 foram refeitas em atendimento à determinação da CVM e encontram-se à disposição dos acionistas na sede da Companhia e na CVM, bem como esclarecendo os motivos do refazimento". Considerando a tendência verificada, caso o compromitente fosse apresentar proposta nesse sentido nos dias atuais, deveria realizar as medidas acima citadas de forma prévia à manifestação final do Comitê de Termo de Compromisso, ou seria apontada a não satisfação do requisito legal.
} 
suspeita deveria decorrer da assinatura do termo - embora representando menores benefícios ao mercado de valores mobiliários se comparado à prática atual da cessação prévia.

Por fim, cabe uma crítica à redação do inciso ora comentado, que qualifica as atividades ou atos a serem cessados para celebração de termo de compromisso como “considerados ilícitos pela Comissão de Valores Mobiliários”. Qualificar as práticas como "conduta sob investigação" parece ser redação mais técnica e adequada, vez que, até o julgamento final administrativo (o qual pode sequer vir a existir, caso o acordo alternativo seja firmado e adimplido pelas partes), os atos e atividades supostamente praticados pelos administrados podem estar sob apuração ou investigação, ser eivados de suspeita de ilicitude ou mesmo serem tratados como potencialmente ilícitos. Mas não é certo qualificar a conduta como ilícita, com o que se estaria antecipando o julgamento, o que o termo de compromisso não faz, inclusive pela supressão do inciso III ao parágrafo $5^{\circ}$, como comentado oportunamente ${ }^{185}$. A exegese do inciso em exame deve, pois, abrandar a literalidade da norma - o que, de fato, ocorre na prática -, sob pena de restar inviabilizada a utilização do instrumento.

Embora em sentido contrário exista o argumento razoável de que os atos, ainda que em tese, possam ser considerados ilícitos, é necessário apresentar tal ressalva, para que sejam feitos os devidos reparos - seja pela reforma da regra, seja pela via interpretativa. Até que exista terminativa apuração e decisão a respeito de autoria, materialidade e intenção do agente, decorrente de julgamento administrativo, a rigor não há ilícito.

\subsubsection{Correção de irregularidades e indenização de prejuízos}

O segundo e último requisito legal limitador da discricionariedade do Colegiado da CVM na análise dos termos de compromisso propostos pelos particulares trata da obrigatoriedade dos proponentes de "corrigir as irregularidades, inclusive indenizando os prejuízos"186.

\footnotetext{
185 “O legislador não foi preciso na redação do inciso I acima transcrito, pois, na realidade, não se pode falar em 'atividades ou atos considerados ilícitos' pela CVM, uma vez que naquele momento ainda não houve julgamento pela autarquia, não restando provada a ilicitude dos atos sob investigação. A partir de uma interpretação sistemática da lei, conjugando o referido inciso com o disposto no $\S 6^{\circ}$ do art. 11 , pode-se concluir que, como o termo de compromisso não importa em confissão quanto à matéria de fato, nem reconhecimento de ilicitude da conduta analisada, os atos ou atividades - objeto do compromisso - não podem ser considerados ilícitos". EIZIRIK (1998, Regime..., p. 103).

${ }^{186}$ Para exemplificar a inafastabilidade da exigência (dita essencial), cita-se a rejeição de acordo proposto no contexto do Processo Administrativo Sancionador 17/2006, apreciado pela Diretoria Colegiada na reunião de 12 de junho de 2012: "O Colegiado, acompanhando o entendimento exarado no parecer do Comitê de Termo de Compromisso, deliberou a rejeição das propostas...". No parecer de 5 de abril de 2012, citado na decisão
} 
Considerando os propósitos do termo de compromisso, uma rápida e consistente reparação das consequências das condutas potencialmente ilícitas, em cada caso, tem o poder não só de encerrar a apuração administrativa, promovida pela Comissão, como de evitar novas medidas de indenização civil, que poderiam ser propostas por terceiros eventualmente prejudicados.

A celebração de termos de compromisso por certo não impede terceiros de pleitearem indenização civil com fundamento exatamente nos mesmos fatos motivadores da apuração administrativa suspensa, considerando a independência das esferas civil e administrativa $^{187}$. Contudo, parece provável que, existindo indenização adequada em decorrência do acordo celebrado com a CVM, inexistirá motivação para o terceiro mobilizar-se perante o Poder Judiciário, visando reparação adicional.

Assim, a imposição de indenização a terceiros prejudicados como requisito essencial à celebração de termos de compromisso, "no que tange ao ressarcimento ao lesado, promove, com eficiência, a possibilidade de o regulador atingir um de seus interesses públicos primários, que é o de corrigir distorções ou assimetrias geradas por ação ou omissão ilícita de seus regulados"188. Exemplifica a citada essencialidade o pensamento exposto informalmente pelo hoje ex-Diretor da CVM, Dr. Eli Loria: “A visão primeira é a indenização. Existe um prejudicado? Então, há que haver indenização, para que se possa firmar o termo de compromisso" 189 .

Efetivamente a celebração de termo de compromisso apresenta-se como interessante mecanismo, por sua função de facilitar indenizações. Explique-se. À CVM, pela adoção da ferramenta tradicional para apuração de responsabilidade por infrações legais ou administrativas, é possibilitado, após o procedimento que culmina com a decisão

do Colegiado, consta que: "Em linha com a manifestação da PFE/CVM, o Comitê conclui pela existência de óbice legal à aceitação das propostas apresentadas, por não atendimento ao requisito inserto no inciso II, $\S 5^{\circ}$, art. 11, da Lei $n^{\circ}$ 6.385/76. Nesse tocante, duas considerações são dignas de registro: a) os prejuízos apontados no relatório da comissão de inquérito remontam a valores superiores a $\mathrm{R} \$ 700$ milhões de reais; b) a obrigação de indenizar, de acordo com a PFE/CVM, alcança o auditor independente e seu diretor, posto que a atuação destes teria sido determinante para a concretização das irregularidades praticadas pelos demais acusados". Já a manifestação da Procuradoria Federal Especializada, consignada no MEMO $\mathrm{N}^{\circ}$ 07/2012/GJU-4/PFE-CVM/PGF/AGU, é explícita ao anotar que “[...] b) segundo o Relatório da Comissão de Inquérito, os prejuízos causados pela controladora [Controladora] aos acionistas da [Companhia] alcançam o montante de R\$ 704.791 mil, atualizados pela taxa SELIC até 31.12.08; c) assim, mostra-se necessário o oferecimento de propostas de indenização aos acionistas prejudicados capazes de indenizar integralmente os prejuízos, não sendo suficiente a mera proposta de ressarcir somente a CVM; d) a atuação dos auditores também foi determinante para a concretização das irregularidades praticadas pelos demais proponentes, não sendo possível excluí-los da responsabilidade de indenizar o dano suportado pelos acionistas; e) dessa forma, as propostas não devem prosperar, uma vez que não foi cumprido o requisito previsto no inciso II do art. 11, $\S 5^{\circ}$, da Lei $6.385 / 76$, referente à indenização dos principais prejudicados".

${ }_{187}$ Sobre o tema, item 13.1, infra.

${ }^{188}$ LEMOS, 2005, p. 23.

${ }^{189}$ Declaração registrada nos Cadernos Direito GV, Seminário 38, v. 7, n. 6, nov. 2010, p. 36. 
administrativa, impor sanções (previstas no artigo 11 da Lei 6.385/76 ${ }^{190}$ ), inclusive multas. No entanto, no sistema vigente, os valores havidos com o pagamento dessas multas não são entregues ou direcionados à(s) parte(s) prejudicadas pela conduta infratora, ainda que o dano seja identificado e quantificado inquestionavelmente. Paralela ou posteriormente, terceiros lesados pela conduta caracterizada (ou ainda pendente de caracterização) como infração administrativa, podem pleitear judicialmente reparação, em nome próprio e às suas expensas ${ }^{191}$.

O termo de compromisso, exatamente pela exigência legal de indenização dos prejuízos causados pela conduta (mesmo sem juízo de mérito a respeito da ilicitude de tal conduta), coloca-se como alternativa que possibilita aos prejudicados obtenção de ressarcimento direto ${ }^{192}$ e independentemente de acionamento do Poder Judiciário ${ }^{193}$. Certamente a possibilidade de indenização a terceiros de maneira célere é uma das grandes contribuições do termo de compromisso, em comparação com a atuação sancionatória tradicional da Comissão, e uma de suas facetas mais interessantes ${ }^{194}$.

\footnotetext{
${ }_{190}$ Alteradas pela Lei 9.457/97, conforme informado no item 4 acima.

${ }^{191}$ Ressalvada a atuação do Ministério Público (inclusive pela ação pública de responsabilidade por danos causados aos investidores no mercado de valores mobiliários, disciplinada pela Lei n. 7.913, de 7 de dezembro de 1989) ou de outras entidades, agindo em nome de uma coletividade de terceiros prejudicados. Sobre a tutela coletiva no mercado de valores mobiliários, cf. TANJI (2009).

192 "[... o implemento do instituto do "consent decree" resulta na viabilidade de obter, para os prejudicados por ação ilícita de acionistas e participantes do mercado, as providências e indenizações que seriam exigíveis através de procedimentos judiciais singulares ou coletivos específicos”. (MORAES, 1999, pp. 109-110).

${ }^{193}$ É sabido que em muitos casos inexiste motivação de terceiros prejudicados (principalmente titulares de investimentos de menor representatividade) para busca de ressarcimento perante o judiciário, considerando o custo e tempo necessário para obtenção de decisão favorável, e os benefícios advindos de tal decisão. Em levantamento realizado no o Tribunal de Justiça do Estado de São Paulo, no período ente 1998 e 2005 , pesquisadores da Escola de Direito de São Paulo da Fundação Getúlio Vargas apuraram que, em matérias relativas ao mercado de capitais, o tempo total mínimo para obtenção de uma decisão final é de 888 dias, e o máximo de 5.049 dias, compondo uma média de 2.618 dias. Relatório disponível em: < http://bibliotecadigital.fgv.br/dspace/bitstream/handle/10438/2813/direito\%2009.pdf?sequence=1 >. Acesso em 08jan2013.

${ }^{194}$ Sobre o tema: “Apesar de deter todos estes poderes [requisitar ao Ministério Público a proposição de ação civil, participar de ações judiciais na posição de amicus curiae, impor punições de monta mais elevada do que anteriormente], a CVM não dispõe de atribuição específica queproduza um resultado concreto em proveito do acionista minoritário, no sentido do seu pronto ressarcimento pelos danos acarretados, em virtude de ato ou fato ilegal praticado por administrador ou controlador de sociedade. O que ocorre, na prática, é que, em muitas situações, o mercado ressente-se de uma atuação mais contundente e efetiva da CVM, que desencadeie um resultado imediato, em proveito do acionista, mas falta-lhe o poder para tanto. Um exemplo do que se está afirmando, e foi vivenciado por muitos, é a falta de poderes da CVM para impor determinado pagamento de dividendos, ou para anular determinado ato societário realizado em desconformidade com a lei, como na alienação de controle, alterações estatutárias, etc. Nessas situações, a sua atuação resume-se à expedição de pareceres de orientação, para afirmar o entendimento do órgão sobre determinada matéria polêmica, ou, no caso de práticas ilegais e ineqüitativas de controlador e administrador, determinar a instauração de inquérito administrativo, com punição das ilicitudes. Contudo, tais ações não trazem, em conseqüência, a imediata sustação ou o desfazimento dos atos ou a reparação dos danos causados aos acionistas ou aos investidores. Estes, para serem ressarcidos, precisam ingressar com as medidas judiciais competentes, às quais a CVM pode comparecer, na qualidade de amicus curiae. Trata-se, todavia, de ações ordinárias de longo curso que somente, muitos anos depois produzem os seus efeitos com o trânsito em
} 
Vale registrar que a reparação de prejuízos não está sujeita à aceitação do terceiro eventualmente prejudicado. Satisfeita a condição acertada com a CVM no termo de compromisso, o acordo substitutivo como um todo será considerado adimplido, e eventuais ressarcimentos adicionais ou complementares que o terceiro entenda serem adequados deverão ser buscados diretamente pelo prejudicado, judicialmente.

Naturalmente, a participação de investidores lesados, conforme prevista no artigo 10 da D. CVM 390/01, tende a minimizar discrepâncias entre o ressarcimento que seja aceitável na avaliação da CVM, e aquele que os terceiros entendam legítimos, pois a CVM será municiada de informações adicionais, às quais possivelmente não teria acesso sem tal participação. Parece que o ressarcimento integral estaria, dessa forma, mais alinhado à racionalidade do termo de compromisso. Porém, a hipótese de insuficiência da reparação pactuada entre a Comissão de Valores Mobiliários e o compromitente é uma realidade, principalmente nos casos em que não há participação dos lesados externos à relação do acordo entre investigado e autoridade na discussão dos valores a serem compromissados.

Não são raros os casos, por outro lado, em que não há um prejudicado (ou um conjunto de prejudicados) já identificado ou identificável. Tem se entendido, em tais situações, como existente um dano ao mercado ${ }^{195}$, à credibilidade do sistema. Por consequência, faz-se necessário, em observância à letra do inciso II ora em análise (contendo o requisito essencial da "indenização de prejuízos" causados pela conduta motivadora do compromisso), ressarcir os prejuízos sofridos pelo mercado, ofertando-se reparação ao conjunto de agentes atuantes no mercado, em nome da Comissão.

Adicionalmente, para que seja alcançada a finalidade disciplinar dos acordos, “nos casos em que não existam prejuízos a ser ressarcidos, a CVM vem entendendo que a obrigação de realizar pagamentos em dinheiro à Autarquia constitui forma adequada de inibir a prática de infrações semelhantes no mercado"196.

\footnotetext{
julgado da sentença, a não ser nos casos de obtenção de medida cautelar ou de tutela antecipada". WALD (2002, pp. 8-9).

195 "O exercício de determinadas atividades econômicas, em certos setores de atividade, como acontece no mercado de capitais, não implica numa relação direta entre parte e contraparte, o que impede o agente econômico de, a tempo e hora próprios, detectar a imperfeição propositadamente criada para ludibriá-lo, de que resulta uma perda patrimonial originada exclusivamente da atuação irregular daquele agente menos escrupuloso. Mais que isso, em decorrência da citada perda, que não fica circunscrita a poucas contrapartes do agente que atuou de modo ilícito, todo um segmento do mercado sofre, o que coloca em risco a credibilidade de todo o sistema". CANTIDIANO (1999, p. 25) sem grifos no original.

${ }^{196}$ EIZIRIK et. al. (2008, p. 344).
} 
Com efeito, em ata de Reunião do Colegiado de 22 de novembro de 2006, tratando de apreciação de proposta de termo de compromisso, é possível destacar a referência à

\begin{abstract}
"[...] recente orientação do Colegiado no sentido de que, além do cumprimento dos requisitos mínimos estabelecidos em lei para a celebração do Termo de Compromisso (cessar a prática de atos ilícitos e de corrigir as irregularidades e indenizar os prejuízos), as prestações em Termos de Compromisso não destinadas ao reembolso dos prejuízos devem consistir em valor suficiente para desestimular a prática de infrações semelhantes pelos acusados e por terceiros que estejam em situação similar à daqueles" ${ }^{\text {197 }}$.
\end{abstract}

Essa prestação, porém, causa certa deformação ao requisito do inciso II em exame, não podendo ser considerada como uma alternativa para o seu cumprimento ${ }^{198}$

${ }^{197}$ Em sede de apreciação de termo de compromisso proposto no âmbito do Processo Administrativo Sancionador CVM n. RJ 2006/5822.

${ }^{198}$ Assim, parece equivocada a fundamentação apresentada pela Procuradoria Federal Especializada embora o escopo seja legítimo - e confirmada no voto do Diretor Wladimir Castelo Branco Castro, apresentado em 8 de abril de 2005, na apreciação de proposta de termo de compromisso apresentado pelos acusados no Processo Administrativo Sancionador CVM n. 11/03: "Relativamente à segunda exigência imposta pelos citados dispositivos - a saber, 'corrigir as irregularidades apontadas, inclusive indenizando os prejuízos' - concordo com o entendimento do PFE. Há de se destacar que a referida indenização abrange não só os prejuízos sofridos por investidores, mas também aqueles que atingirem o mercado ou à CVM, nos termos do artigo $7^{\circ}$, inciso II, da Deliberação CVM $n^{\circ} 390 / 01$, de forma que danos desta natureza apresentam-se passíveis de recomposição através da assunção de compromissos que visem a proporcionar algum benefício ao mercado de valores mobiliários, como forma de compensação pelos prejuízos advindos do possível ilícito praticado. Eis que o compromisso de desenvolver um programa de informática com vistas a simplificar o acesso a informações por parte do público em geral apresenta-se de modo a propiciar benefícios ao mercado de valores mobiliários, atendendo de modo oportuno e suficiente a satisfazer as exigências da Lei no tocante à celebração de Termo de Compromisso". Linha argumentativa similar pode ser identificada no voto do Diretor Relator a respeito de propostas de termo de compromisso apresentadas durante a apuração de condutas ocorrida pelo Processo Administrativo Sancionador CVM SP 2005/0128, em que concluiu o Diretor Pedro Oliva Marcilio de Sousa que "Não se observa nas propostas apresentadas o preenchimento dos requisitos contidos no inciso II, $\S 5^{\circ}$, art. 11, da Lei $6.385 / 76$ " as quais "deve [sic] ser rejeitadas por não conterem qualquer prestação por parte dos Indiciados que possa servir como uma compensação pelos danos sofridos pelos prejuízos causados ao mercado ou a esta Autarquia.”. Não é a rejeição das propostas que se questiona, mas a sua fundamentação. À época, escreveu-se no mesmo sentido, sendo possível citar LEMOS (2005, p. 20), para quem "a indenização [...] não se refere somente aos participantes do mercado de valores mobiliários. O Colegiado tem o entendimento de que o ressarcimento pode ser feito também das despesas empreendidas pelo próprio Regulador, ou seja, a CVM. Tais despesas decorrem da implementação de investigações adicionais e procedimentos administrativos provocados pelo administrado". Não parece ser o caso. Em situações limites, por exemplo, a Comissão se colocaria em situação de conflito de interesse, motivada a celebrar acordos, com reflexos em proveito próprio. Como bem esclareceu o Diretor Eliseu Martins, no relatório da apreciação de proposta de termo de compromisso em sede do Processo Administrativo Sancionador CVM N. RJ 2006/4665, "Observo, todavia, que, conforme já manifestado pela Procuradoria Federal Especializada em casos precedentes, o compromisso de pagar à CVM determinada quantia a título de ressarcimento pelos custos incorridos com o processo não se revela juridicamente adequado, visto que se trata de atribuição legal já custeada pelos cofres públicos. Ademais, o inciso XI do parágrafo único do art. $2^{\circ}$ da Lei $n^{\circ} 9.784 / 99$ veda a cobrança de quaisquer despesas processuais, ressalvadas as previstas em lei. Dessa forma, o pagamento a ser feito a esta autarquia tem por finalidade desestimular a prática de condutas semelhantes.”. Deve-se ressaltar que os potenciais compromitentes certamente ampararam-se em casos anteriores, em que o ressarcimento de despesas fora aceito pela CVM, inclusive sendo referido em termos de compromisso firmados, como naquele assinado pela CVM e os acusados no Inquérito Administrativo CVM N. 02/01, em que uma das obrigações contraídas pelos 
embora a adoção de tal exigência seja razoável dentro da lógica disciplinar dos termos de compromisso, além de ser consentânea com a discricionariedade da Comissão na aplicação do instituto.

"De fato, pode ocorrer que as condutas sob investigação da CVM não tenham causado qualquer prejuízo ao mercado, aos investidores ou à própria CVM", conforme aponta EIZIRIK (2008, p. 344), e então inexistiria prejuízo a ser indenizado. O mesmo autor $^{199}$ entende que a Lei 6.385/76 coloca como condições para que haja indenização de prejuízos a possibilidade de comprovação da existência inequívoca de tais prejuízos, a quantificação das perdas sofridas e a viabilidade de identificação dos afetados, para atribuir a cada um o seu quinhão respectivo. Assim, seria inadequada a sistemática de indenizar a autarquia responsável pela regulação por prejuízos causados aos direitos difusos no mercado.

Alternativamente (melhor: em complementação) à sistemática de "danos ao mercado", os quais por vezes não são individualizáveis ${ }^{200}$ para fins de efetivação da correspondente reparação, sugeriu-se $\mathrm{e}^{201}$ a adoção de mecanismo assemelhado ao previsto no artigo $2^{\circ}$ da Lei n. 7.913 , de 7 de dezembro de 1989, pelo qual o investidor, convocado por edital, habilita-se para receber a parcela indenizatória que lhe é de direito. A ideia seria permitir a indenização aos investidores lesados, mesmo àqueles identificados apenas posteriormente à celebração do acordo entre a CVM e o investigado, em consonância com a dinâmica contemplada pelo artigo 11 da D. CVM 390/01, criada para regular questões

proponentes foi "pagar à CVM a importância de $\mathrm{R} \$ 50.000,00$ (cinqüenta mil reais), a título de ressarcimento por despesas administrativas incorridas no curso deste Inquérito Administrativo". Entendimento diverso, e aparentemente mais técnico, tem sido apresentado recentemente, como v.g. no parecer do Comitê de Termo de Compromisso datado de 18 de setembro de 2012 (exame de proposta apresentada pelos acusados no Processo Administrativo Sancionador CVM N. RJ 2012/1643): “o Comitê sugere o aprimoramento da proposta a partir da assunção de obrigação pecuniária no montante de $\mathrm{R} \$ 20.000,00$ (vinte mil reais) em benefício do mercado de valores mobiliários, por intermédio de seu órgão regulador, ao qual incumbe, dentre outros, assegurar o funcionamento eficiente e regular desse mercado (art. $4^{\circ}$ da Lei $n^{\circ}$ 6.385/76)". Sem colocar a obrigação pecuniária como decorrente do inciso II, ora em comento, parece irretocável (sob o ponto de vista jurídico) o posicionamento do Comitê.

${ }_{199}$ EIZIRIK et. al. (2008, p. 344).

200 “[...] se sustenta que, a prática, existe grande dificuldade em se averiguar os efetivos danos causados aos investidores em decorrência de ações criminosas lesivas ao Mercado de Capitais. O Mercado de Capitais tem suas negociações caracterizadas, via de regra, pela impessoalidade e anonimato entre as partes. Trata-se de verdadeiro jogo de 'soma zero', onde uma das contrapartes sempre perde, dado que as cotações dos valores mobiliários são variáveis de acordo com a relação oferta e demanda. Decorre daí imensa dificuldade em se identificar os reais prejudicados. [...] Verifica-se, de igual sorte, grande dificuldade em se mensurar os efetivos prejuízos, haja vista, por exemplo, que as cotações nem sempre são influenciadas quando da divulgação de uma informação relevante, tratando-se de verdadeiro exercício de suposições. [...] São, pois, diversos os fatores que determinam a formação do preço dos valores mobiliários, havendo substancial dificuldade em se aferir concretamente os reais prejudicados e em qual monta."ALONSO, L. O bem jurídico nos crimes contra o mercado de capitais. in Revista Brasileira de Ciências Criminais 82/129, 2010.

${ }^{201}$ Parecer/CVM/PJU/005, de 10 de março de 1998. 
procedimentais relacionadas aos termos de compromisso. O racional adotado é, sempre que possível, identificar os investidores que foram prejudicados pela ação ou omissão infratora às normas, para uma efetiva e rápida recomposição.

De fato, nos termos de compromisso em que não existe prejuízo a ser sanado, tem-se observado que são propostos pagamentos com o escopo de "desestimular a adoção de condutas similares" ${ }^{\text {202 }}$, como grafado, exemplificativamente, no Parecer do Comitê de Termo de Compromisso datado de 20 de junho de 2012, apresentado no Processo de Termo de Compromisso CVM N. RJ 2012/4905, decorrente do Processo Administrativo Sancionador CVM N. RJ 2011/11171:

\begin{abstract}
“[...] considerada também, conforme já exposto acima, a perspectiva de ordem moral e de desestímulo a práticas semelhantes [...] buscou-se alcançar a dupla finalidade de: a) estabelecer um compromisso compatível com a natureza e reprovabilidade da conduta imputada na peça acusatória; e b) desestimular outros agentes de mercado - em situação similar a da proponente - a adotarem comportamento semelhante, valendo-se do caráter norteador e pedagógico do instituto do Termo de Compromisso".
\end{abstract}

A seguir, vale citar exemplo de situação em que a "correção das irregularidades apontadas e indenização de prejuízos" ocorreram de forma diversa do usual.

Tratam-se das propostas de acordo apresentadas pelos investigados no Processo Administrativo Sancionador CVM 16/2008, em relação às quais a Procuradoria Federal Especializada apresentou objeção ${ }^{203}$, afirmando que

\begin{abstract}
"Quanto à análise do atendimento ao inciso II da mesma Deliberação (correção das irregularidades com indenização dos prejuízos), convém ressaltar que os fatos objeto deste inquérito representam operações consideradas indevidas, porém realizadas e findas no âmbito do mercado de capitais há pelos menos 2 (dois) anos, o que toma inviável sua reversão. Por outro lado, é exigível uma compensação pelos prejuízos ocorridos".
\end{abstract}

Posteriormente, os acusados apresentaram declaração da companhia que administravam, supostamente lesada pela conduta, pela qual ficou declarada a

\footnotetext{
${ }^{202}$ WELLISCH e SANTOS (2009, p. 5) apresentam a mesma conclusão: "considerando a impossibilidade material de quantificação de prejuízos em situações com a acima referida, cumpre ao Colegiado da CVM, em caráter discricionário, e após ouvido o adiante enfocado Comitê de Termo de Compromisso, examinar se a proposta apresentada se revela razoável e finalisticamente proporcional aos danos potencialmente causados. Hodiernamente, está sedimentado na CVM o jurídico entendimento segundo o qual 'as prestações em termos de compromisso não destinadas ao reembolso dos prejuízos devem consistir em pagamento de valor suficiente para desestimular a prática de infrações semelhantes pelos indiciados e por terceiros que estejam em posição similar à dos indiciados' [nesse trecho os autores referem-se ao Processo Administrativo Sancionador CVM RJ n. 2005/9059]".

${ }^{203}$ Consignada no MEMO/PFE-CVM/GJU-1/N. 391/2010.
} 
“[...] sua não oposição à celebração do Termo de Compromisso, na medida em que (i) a aprovação das contas pela Assembleia [...] importou em quitação de todos os administradores, com exceção daquele expressamente ressalvado pela referida assembleia; e (ii) transcorreu in albis o prazo decadencial para o ajuizamento de eventual ação de anulação daquela deliberação (e da que foi tomada em 24.11.2008, de propor ação de indenização somente contra o referido administrador). Por estas razões, como a Companhia considera que não faz jus a qualquer indenização contra os Requerentes, não se opõe à celebração de Termo de Compromisso que não imponha o pagamento de tal indenização" ${ }^{204}$.

Com isso, foi alterado o posicionamento da Procuradoria ${ }^{205}$, que entendeu “após a expressa manifestação da companhia lesada no sentido, materialmente, da renúncia a quaisquer valores ofertados como condição para celebração do presente acordo, não vislumbra[r] óbices jurídicos à celebração do Termo de Compromisso, nos termos ora propostos" $^{206}$.

Por fim, cumpre, a exemplo do referido no item imediatamente anterior, comentar a atecnicidade na redação do inciso II do parágrafo $5^{\circ}$ do artigo 11 da Lei 6.385/76. A rigor, inexistem "irregularidades" confirmadas no momento da proposição de termo de compromisso pelo administrado. O que há são não mais do que supostas ou potenciais irregularidades, as quais só virão a ser confirmadas após o julgamento, o que pressupõe a hipótese de não chegar a existir termo de compromisso, ou de esse ser desatendido pelo compromitente, acarretando a retomada do processo administrativo sancionador.

\subsection{Inexistência do reconhecimento de culpa}

Desde 1979 já se delineavam dois objetivos, pelo corpo jurídico da própria CVM, a serem buscados na celebração dos termos de compromisso: (i) o possível auxílio, em ações de reparação civil, a ser proporcionado pela admissão de responsabilidade perante a CVM; e, de forma secundária e menos relevante ${ }^{207}$, (ii) a simplificação procedimental $^{208}$.

\footnotetext{
${ }^{204}$ Manifestação da companhia referida no parecer do Comitê de Termo de Compromisso, datado de 28 de agosto de 2012.

${ }^{205}$ Conforme o MEMO/PFE-CVM/GJU-1/Nº 028/2012.

206 Apenas a título informativo, após novas propostas, o Comitê seguiu entendendo inapropriada a aceitação da proposta, apesar de cumpridos os requisitos objetivos do artigo 11 parágrafo $5^{\circ}$ da Lei 6.385/76, por o caso “demandar um pronunciamento norteador por parte do Colegiado em sede de julgamento — até por ser este o momento apropriado à análise dos pormenores de cada conduta —, visando a bem orientar as práticas do mercado em operações dessa natureza". O Colegiado, entretanto, em 4 de setembro de 2012, decidiu aceitar as propostas de termo de compromisso, "por entendê-las oportunas e convenientes, uma vez que os valores dos compromissos se afiguram proporcionais à gravidade das acusações já formuladas [...], suficientes para desestimular a prática de condutas assemelhadas".

207 “[...] enfocando-se a questão do ponto de vista das finalidades estruturais da própria CVM, entre as quais se inclui, com posição de destaque, a proteção do acionista minoritário. Na medida em que [...] o consent
} 
A racionalidade adotada parecia ser obter a confissão da irregularidade dos atos ou atividades praticados pelo signatário do termo de compromisso, a fundamentar diretamente o pleito de ressarcimento por terceiros prejudicados, na esfera civil. Essa lógica, no entanto, se choca com a redação parágrafo $6^{\circ}$ do artigo 11 da Lei 6385/76 209 , verbis: “[...] $\$ 6^{\circ} \mathrm{O}$ compromisso a que se refere o parágrafo anterior não importará confissão quanto à matéria de fato, nem reconhecimento de ilicitude da conduta analisada".

Assim sendo, evidentemente não há confissão quanto a quaisquer fatos, bem como quanto à regularidade ou não das condutas objeto da celebração de acordos administrativos, sejam elas infrações em relação às condutas rotineiras das companhias, administradores ou outros agentes ${ }^{210}$, ou modificações estruturais ${ }^{211}$.

Há, exclusivamente - em adição à correção de desvios eventualmente indicados e da recomposição de prejuízos porventura ocorridos - concordância do compromitente com a interrupção da conduta indicada, sem que esta seja objeto de avaliação ou juízo. Naturalmente, tal interrupção aplica-se apenas nos casos em que o comportamento considerado potencialmente ilícito seja continuado e ainda persista, no momento da celebração do termo de compromisso, como referido no item 4.3.1.

A inexistência de confissão ou reconhecimento de ilicitude da conduta do compromissário traz como consequência lógica a manutenção da presunção de inocência $^{212}$. Essa presunção poderá ser invocada e deverá ser considerada caso terceiros venham a questionar os atos ou atividade praticados pelo administrado (em busca de indenização em decorrência de prejuízos derivados da conduta sobre a qual foi firmado

decree fosse entre nós adotado, caberia à CVM zelar para que desde logo o reconhecimento feito pelo infrator servisse também como confissão extra-judicial dos fatos de que poderia advir para o investidor prejudicado o direito de postular civilmente uma indenização pelo prejuízo. [...] Só se justificaria, de fato, a adoção de algo similar ao "consent decree" nestas bases, i.e. dentro do aspecto de maior grandeza da atividade da CVM, que não se pode encarar como um simples órgão punitivo, mas sim como uma entidade destinada precipuamente a tutelar o mercado de valores mobiliários e, nele, a sua figura mais importante - o investidor, ainda que para isto tenha de exercitar o poder de punir". ARAGÃO e SANTOS (1979, p. 2).

208 ARAGÃO e SANTOS (1979, p. 3) afirmaram que "apenas pela finalidade sub [simplificação procedimental], julgamos que a medida [...] não se justificaria, servindo somente para emprestar uma feição à CVM, sob certos aspectos, negativas".

${ }^{209}$ Sobre a hipótese que foi afastada pela opção do legislador, ao optar por não dotar o termo de compromisso da natureza de confissão das condutas: “[...] considerando os efeitos da confíssão de fatos, poder-se-ia admitir que as pessoas prejudicadas pelo ato ilícito se utilizassem da confissão como prova, em pleito judicial objetivando a indenização pelas perdas e danos que lhes tiverem sido causados pelo infrator". MORAES (1999, p. 106).

${ }^{210}$ V.g. prestação de informações obrigatórias ou observância dos deveres prescritos na legislação.

${ }^{211}$ V.g.: aquisição de controle de companhia sem observância de procedimentos de oferta ou manipulação do mercado, com divulgação de fatos relevantes que não correspondam à realidade.

212 A exemplo do que ocorre, em regra, nos acordos firmados com a SEC norte-americana. STEINBERG (2009, p. 435) anota que "The overwhelming percentage of the SEC enforcement actions are settled pursuant to the consent negotiation process where the defendant neither admits nor denies the Commission's allegations". 
acordo, por exemplo), ou o processo administrativo sancionador seja retomado na eventualidade de não cumprimento do acordo celebrado.

É possível constatar a existência de um descompasso entre o não reconhecimento de culpa, no sentido jurídico, e o reflexo da proposição de um termo de compromisso perante o mercado.

Ainda que um agente econômico tenha motivações para celebração de acordos com a CVM, mesmo nos casos em que não seja culpado das condutas a ele imputadas ${ }^{213}$, a apresentação de uma proposta, e a posterior concordância com exigências da Comissão no curso das negociações conduzidas pelo Comitê de Termo de Compromisso, podem ser entendidas como evidência de "reconhecimento" (não jurídico, mas moral e reputacional) de culpa, conforme declaração do ex-Diretor da CVM, Dr. Eli Loria ${ }^{214}$ :

\begin{abstract}
"E por mais que se diga que o termo de compromisso não reconhece a culpa, sempre fica aquele ranço ali, uma marca na reputação, não é? O problema reputacional é o que mais importa à pessoa, a um profissional de mercado e tudo, é aquela marca que fica. Não é pagar $100 \mathrm{mil}, 200 \mathrm{mil}$, porque isso aí tem seguro, o seguro paga e não é o problema. O problema é reputacional".
\end{abstract}

No mesmo seminário ${ }^{215}$, o Professor José Marcelo Martins Proença apresentou pensamento relacionado, ao expor que

\begin{abstract}
"[...] o termo de compromisso, principalmente quando vinculado com quantias consideráveis em dinheiro, para pagamento, mais configuram um indício de confissão - confissão não tem indício - mas mais configura um reconhecimento da conduta, do que um desconforto ou uma segurança para a própria Administração Pública de conseguir a condenação ou do risco de o Poder Judiciário rever a decisão da Administração Pública. [...] Dependendo de como o compromisso é assinado e, muitas vezes, acompanhado de uma contribuição em dinheiro, que aquele investigado paga para ter a suspensão do processo, aquilo configura mesmo um indício de reconhecimento de culpa".
\end{abstract}

É possível, então, afirmar, consoante a previsão legal específica, que inexiste "confissão quanto à matéria de fato, nem reconhecimento de ilicitude da conduta analisada" com efeitos jurídicos, inclusive com relação à manutenção de primariedade em condenações administrativas e assegurando a preservação da possibilidade de ocupar cargos em companhias abertas (inexistindo declaração de inabilitação, pela Comissão, mesmo nos casos em que o compromitente acorde o não exercício de determinadas

\footnotetext{
${ }^{213}$ Conforme será verificado o item 6.2.

214 Cadernos Direito GV, Seminário 38, v. 7, n. 6, nov. 2010, p. 37, Disponível em: <http://bibliotecadigital.fgv.br/dspace/bitstream/handle/10438/8491/Caderno_DIREITO_GV_38.pdf.txt?sequ ence $=4>$, acesso em 08out2012.

${ }^{215}$ Registrado na p. 46 da mesma publicação.
} 
atividades por certo período ${ }^{216}$ ). Ainda que a celebração de termos de compromisso nem sempre represente ao compromitente a manutenção de integridade reputacional perante o mercado.

\subsection{Inspiração no instituto análogo do direito concorrencial}

O chamado compromisso de cessação, há tempos previsto no regramento concorrencial brasileiro, sabidamente serviu de inspiração e parâmetro para a adoção do termo no contexto do mercado de valores mobiliários. O objetivo deste item, seguindo o escopo central do texto, é apresentar a contextualização dos acordos no direito dedicado à defesa da concorrência e suas características gerais, a fim de identificar pontos diferentes entre os acordos com o CADE e com a Comissão, que sirvam para melhorar estes últimos $^{217}$.

Ainda durante a vigência da Lei n. 4.137, de 10 de setembro de $1962^{218}$, especificamente por obra do artigo 15 do Regulamento da aludida lei (aprovado pelo Decreto n. 92.323, de 23 de janeiro de $1986^{219}$ - “Decreto $92.323 / 86$ ”) ${ }^{220}$, foi instituído o compromisso de cessação. Por essa norma, o CADE suspenderia a sindicância ou processo em curso, sem que houvesse confissão quanto às condutas imputadas ao compromitente ou aplicação de qualquer penalidade, desde que o administrado assumisse o compromisso de interromper a prática investigada.

A disciplina legal da então nova ferramenta, pela qual expressamente inexistiria reconhecimento de culpa e aplicação de penalidade, restringiu-se a um único artigo, acima referido. Não houve detalhamento do procedimento a ser adotado e, mesmo representando importante avanço, germinal em matéria de compromissos de cessação, teve

\footnotetext{
${ }^{216}$ Exemplificativamente, o termo de compromisso firmado em 5 de abril de 1999, no contexto do Processo Administrativo de Rito Sumário CVM n. SP 97/0250, e o acordo assinado em 13 de setembro de 2006, para extinguir o Processo Administrativo Sancionador CVM n. 12/04.

217 Além do contexto da repressão às infrações à ordem econômica, válido anotar que há ferramentas assemelhadas, em maior ou menor medida, ao termo de compromisso (i) na busca à preservação ambiental, (ii) no contexto do Estatuto da Criança e do Adolescente; e (iii) nas ações civis públicas por danos causados ao meio-ambiente, consumidor, bens e direitos de valor artístico, estético, histórico, turístico e paisagístico, por infração da ordem econômica, à ordem urbanística ou a qualquer outro interesse difuso ou coletivo.

${ }^{218}$ Legislação disciplinadora da repressão ao abuso de poder econômico, e que seguiu em vigor até a sanção da Lei n. 8.884, de 11 de junho de 1994 (“Lei 8.884/94").

${ }^{219}$ Interessante notar ser tal diploma contemporâneo ao anteprojeto de alteração da Lei 6.385/76, citado no item 3.2 acima.

220 "COMPROMISSO DE CESSAÇÃO - Art 15. Se, durante qualquer fase da sindicância ou dos procedimentos, a parte a eles submetida assumir o compromisso de cessar a prática sob investigação, o CADE suspenderá a sindicância ou o processo, sem que tal compromisso implique na confissão de ocorrência de abuso do poder econômico, inexistindo conseqüentemente penalidade a ser aplicada".
} 
sua efetividade restrita. Conforme verificação realizada ${ }^{221}$, nenhum acordo do tipo foi assinado durante a vigência da referida regra.

Em 8 de janeiro de 1991 foi sancionada a Lei n. 8.158, instituidora de normas para a defesa da concorrência, e que veio complementar a disciplina então vigente para repressão ao abuso de poder econômico. Tal diploma teve seu regulamento aprovado pelo Decreto n. 36, de 14 de fevereiro de 1991, sendo responsável pela introdução de regra pela qual a então existente Secretaria Nacional de Direito Econômico suspenderia o processo por prazo que julgasse conveniente, desde que (i) o agente reconhecesse a procedência da representação ou do procedimento e (ii) prestasse compromisso de fazer cessar a prática da infração. Findo esse prazo, a depender da conduta do agente, poderia ser determinado o prosseguimento ou o arquivamento do expediente ${ }^{222}$.

Parece ser pouco provável que algum investigado aceitasse tais termos, uma vez que a situação fora agravada em relação ao cenário anterior, pois passou a ser exigido o reconhecimento do cometimento de atos ilícitos por um potencial compromitente, antecipando o pior resultado possível de um eventual processo administrativo. Além disso, seguia inexistindo segurança quanto aos procedimentos atinentes a tal acordo. O cenário não mudou, e novamente acordo algum do tipo foi assinado, sob a "nova" disciplina ${ }^{223}$.

Paralelamente, o único acórdão do Superior Tribunal de Justiça a tratar de compromissos, seja no âmbito da repressão às infrações à ordem econômica, seja no contexto da tutela do mercado de valores mobiliários ${ }^{224}$, data deste período e trata exatamente do reconhecimento do delito econômico como requisito essencial, à época, para a suspensão do processo ${ }^{225}$.

A exemplo da dúvida que fora suscitada com relação à regra do artigo 11 , parágrafo $5^{\circ}$, da Lei 6.385/76, anteriormente à Reforma de $2001^{226}$, existiram, também nesse cenário, questionamentos a respeito da suposta existência de um direito do

${ }^{221}$ SAITO (2011, p. 15).

${ }^{222}$ Artigo $5^{\circ}$ do Regulamento anexo ao Decreto n. 36, de 14 de fevereiro de 1991.

${ }^{223}$ SAITO (2011, p. 16).

${ }^{224}$ Em levantamento feito até 23 de outubro de 2012.

${ }^{225}$ Mandado de Segurança 2.637-6/DF, Primeira Seção, Rel. Min. Hélio Mosimann, j. 14 de dezembro de 1993, v.u., assim ementado: "Mandado de segurança. Multa imposta pelo Conselho Administrativo de Defesa Econômica - CADE. Recurso Administrativo. Desprovimento pelo Ministro da Justiça. Autoridade Coatora. Confissão do agente a possibilitar a suspensão do processo. Inocorrência. Segurança denegada. [...] Dispondo a lei que o reconhecimento da providência da representação ou do procedimento de ofício, com o compromisso de fazer cessar a prática da infração, leva à suspensão e até ao arquivamento do processo, para alcançar o benefício deveria a empresa impetrante ter confessado a violação à ordem econômica. Não havendo o reconhecimento da prática ilícita - desabastecimento do mercado - não há como conceder a segurança pelo fundamento invocado".

${ }^{226}$ Confira-se a respeito o item 5 , infra. 
administrado na celebração de um termo, ou se tal ato administrativo seria discricionário, notadamente entre a primeira referência aos termos no contexto concorrencial (Decreto 92.323/86) e a alteração na Lei 8.884/94 promovida pela Lei n. 11.482, de 31 de maio de 2007 (“Lei 11.482/07”, responsável pela clarificação da redação) 227.

Não se está a dizer que, considerando o tema tratado no item 2.3 e os argumentos ali relacionados, parecesse correto entender ser a celebração do termo de compromisso um direito do administrado (ainda que, por vezes, o Judiciário tenha assim entendido $^{228}$ ). Tempos depois, a segunda redação, mais clara e inequívoca do artigo 53 da

${ }^{227}$ Sobre o tema, LOBÃO ( p. 92); TURRA (p. 186 e ss.); e SAITO (2011, pp. 17-21).
${ }^{228}$ Conforme é possível depreender de algumas decisões do Tribunal Regional Federal da $1^{\text {a }}$ Região: Apelação em Mandado de Segurança 2002.34.00.007525-4/DF, 6 ${ }^{\mathrm{a}}$ Turma, Rel. Des. M. Isabel G. Rodrigues e J. F. David W. de Abreu Pardo, j. 23 de julho de 2007, maioria: “Administrativo. Infração à ordem econômica. Compromisso de cessação de prática com o Conselho Administrativo de Defesa Econômica CADE. Direito do representado. Improvimento da apelação e da remessa oficial. 1. Atendidas as exigências legais, constitui direito da empresa representada celebrar compromisso de cessação de prática sob investigação com o Conselho Administrativo de Defesa Econômica - CADE, em qualquer fase do processo administrativo (artigo 53 da Lei n. 8.884/94). 2. Improvimento da apelação e da remessa oficial". Interessante notar, nesse julgado, que o relator, fazendo remissão à lógica penal referida no item 3.2.3, coloca a celebração do acordo como um ato vinculado e não discricionário: "Não se trata o compromisso, portanto, apenas de um ato discricionário da Administração Pública. Há um direito do representado de alcançar essa forma de pôr fim ao processo de investigação, certamente se observando os requisitos da lei. Somente no caso de a empresa interessada não atender aos requisitos legais e aqueles estabelecidos pela Administração Pública é que não poderia usufruir a prerrogativa concernente ao compromisso de cessação de prática sob investigação [...]". Também no voto do relator encontra-se afirmação insinuando que, sempre que houvesse interesse do administrado na celebração de um termo (e fossem cumpridos os respectivos requisitos), deveria ser adotado o acordo, com satisfação do interesse público: "Reafirmo que o reconhecimento desse direito guarda simetria com os outros sistemas punitivos do direito e não traz qualquer prejuízo à coletividade, verdadeira titular dos bens jurídicos protegidos pela Lei n. 8.884/94 (artigo $1^{\circ}$, parágrafo único). Isso porque pelo termo de compromisso se alcança a finalidade do sistema administrativo de defesa da ordem econômica, que é restaurar a concorrência, sem as delongas do processo administrativo e de eventuais ações judiciais, 'evitando ainda os altos custos financeiros normalmente infligidos a todas as partes envolvidas' (Neide Mallard, em citação extraída da própria peça de razões recursais do Apelante, fl. 646)".

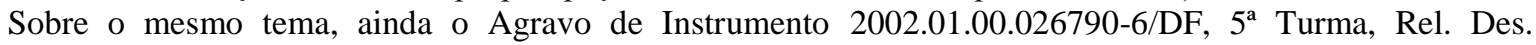
Fagundes de Deus, j. 22 de setembro de 2003, v.u.: "Administrativo e processual civil. Agravo de instrumento. Postos de combustíveis. Infração à ordem econômica. Celebração de compromisso de cessação de prática com o Conselho Administrativo de Defesa Econômica - CADE. Fatos ocorridos anteriormente à edição da Lei 10.149/2000, que restringiu o campo de abrangência do art. 53 da lei 8.884/94. Incidência do brocardo tempus regit actum. 1. As empresas-agravantes possuíam, à vista do regramento contido no art. 53 da Lei 8.884/94, a prerrogativa de celebrar com o CADE compromisso de cessação de práticas infracionais à ordem econômica ocorridas sob a vigência da referida lei, quando em curso o processo administrativo. 2. A Lei 10.149/2000, ao excluir a possibilidade de se celebrar termo de compromisso nos casos das infrações contra a ordem econômica relacionadas nos incisos I, II, III e VIII do art. 21, não erigiu, simplesmente, normas de direito processual, mas, sim, de direito material, na medida em que subtraiu, como conseqüência, direito já constituído em favor da pessoa jurídica que houvesse cometido tais atividades infracionais, pelo que é aplicável a expressão tempus regit actum. Precedente do colendo STJ. [...]4. Agravo de instrumento parcialmente provido".

Outro precedente: Medida Cautelar 2004.01.00.024168-1/DF, 6 ${ }^{\mathrm{a}}$ Turma, Rel. Des. M. Isabel G. Rodrigues e J. F. David W. de Abreu Pardo, j. 23 de julho de 2007, maioria: "Medida cautelar. Suspensão dos efeitos da sentença que concedeu a segurança. Improcedência. 1. Negou-se provimento a apelação interposta nos autos do processo principal (2002.34.00.0007525-4), ao entendimento de que "atendidas as exigências legais, constitui direito da empresa representada celebrar compromisso de cessação de prática sob investigação com o Conselho Administrativo de Defesa Econômica - CADE, em qualquer fase do processo administrativo (artigo 53 da Lei n. 8.884/94) [...]". 
Lei $8.884 / 94^{229}$, com referência expressa ao juízo de conveniência e oportunidade da administração, explicitando sua discricionariedade, eliminou qualquer dúvida e argumentos contrários, bem como alterou a tendência das decisões judiciais de segunda instância, relacionadas a casos ocorridos após a vigência da Lei $11.482 / 07^{230}$. Tal certeza é compartilhada também por estudiosos dos acordos substitutivos firmados no campo concorrencial $^{231}$.

Os compromissos de cessação previstos na legislação aplicável ao Sistema Brasileiro de Defesa da Concorrência, tanto na regra antiga ${ }^{232}$ quanto na lei vigente ${ }^{233}$,

Por derradeiro: Apelação Cível 2002.34.00.039067-2/DF, 5a Turma, Rel. Des. Fagundes de Deus, j. 26 de setembro de 2007, maioria: "Administrativo. Conselho Administrativo de Defesa Econômica (CADE). Representação para apuração de infração à ordem econômica. Postos de combustíveis. Compromisso de cessação de prática (art. 53, da Lei n. 8.884/1994). Direito do representado. Embargos infringentes. Desprovimento. 1. De acordo com o art. 53 da Lei n. 8.884/1994, com a redação anterior à vigência da Lei n. $10.149 / 2000$, que o alterou, constitui direito do representado em processo administrativo, objetivando a apuração de prática de infração à ordem econômica, a celebração de termo de compromisso de cessação da prática, que só poderá ser negado ao interessado se não houver concordância com as cláusulas do aludido termo, previstas em lei, não podendo a Administração criar obstáculos ao exercício do direito, não amparados na legislação que rege a matéria. 2. Embargos infringentes desprovidos". Todos sem grifos nos originais.

${ }^{229}$ Cuja correspondência na vigente Lei 12.529, de 30 de novembro de 2011 ("Lei 12.529/11"), encontra-se no seu artigo 85.

${ }^{230}$ Os acórdãos do Tribunal Regional Federal da $1^{\text {a }}$ Região, posteriores à reforma do artigo 53 empreendida em 2007 e que abordam o tema (até 24 de outubro de 2012) são:

Agravo de Instrumento 2007.01.00.059730-8/DF, $7^{\mathrm{a}}$ Turma, Rel. J.F. Rafael P. Soares Pinto, j. 28 de abril de 2008, v.u.: Processual civil - CADE - Não celebração de termo de compromisso de cessação de conduta ("TCC") - Juízo de conveniência e oportunidade (art. 53 da lei n. 8.884/94) - Ato discricionário. 1. Há previsão expressa no art. 53 da Lei n. 8.884/94 de que a celebração do termo de "compromisso de cessação da prática sob investigação ou dos seus efeitos lesivos" faz parte do âmbito de discricionariedade da Administração, pois vinculada a "juizo de conveniencia e oportunidade" do CADE. 2. Tratando-se, portanto, de ato administrativo discricionário, não há falar em "direito subjetivo" dos agravantes à celebração do termo de compromisso. Havendo, no caso, recusa justificada por parte do CADE, não há falar em irregularidade na conduta do Conselho. 3. Agravo de instrumento não provido [...]".

Agravo Interno no Agravo 2002.01.00.041196-0/DF, 7 Turma, Rel. J.F. Rafael P. Soares Pinto, j. 1 de julho de 2008, v.u.: "Administrativo e processual civil - Sanções impostas pelo "CADE" - Liminar em medida cautelar - "fumus boni iuris" ausente - presunções em prol do ato administrativo - seguimento negado agravo interno não provido. 1 - As sanções aplicadas pelo CADE ao agravante por abuso do poder econômico (cartelização), medidas previstas em lei (art. $7^{\circ}$ da Lei n. 8.884/94), são, porque oriundas de processo administrativo, que se presume legal e veraz, legítimas, não se podendo, por liminar, afastá-las, pois tal consubstanciaria flagrante ofensa ao princípio do devido processo legal, salvo evidências concretas e unívocas aqui não vislumbradas: ausente, assim, o fumus boni iuris. Tampouco há falar em "periculum in mora" se o suposto dano advém de ato omissivo dos próprios agravantes. 2 - O Termo de Compromisso de Cessação de Prática (TCCP) não é direito dos agravantes - que não negam a prática dos atos tidos por reprováveis - mas faculdade do CADE, de acordo com o art. 53 da Lei n. 8.884/94. 3 - Agravo interno não provido [...]". Todos sem grifos nos originais.

Há outro acórdão, referente aos Embargos Infringentes em Apelação Cível de autos n. 2002.34.00.0390672/DF e datado de 31 de maio de 2011, decidido no voto-desempate do Presidente da Terceira Seção do Tribunal, que desproveu os embargos e manteve decisão anteriormente proferida, sob a égide da Lei 8.884/94, anterior à modificação legislativa de 2007.

231 "Ao escolher a celebração do TCC, o administrado estará diante de um direito [...]. Não se trata, entretanto, de direito subjetivo, que será concedido por mero pedido do requerente na existência de requisitos". SAITO (2011, p. 24).

${ }^{232}$ Artigo 53 da Lei 8.884/94.

${ }^{233}$ Artigo 85 da Lei 12.529/11. 
encontram-se pormenorizadamente regulados $^{234}$, o que não ocorrera nos diplomas anteriores e tampouco na Lei 6.385/76. Como referido no item 4 - e será objeto de análise no item 9 -, no âmbito do mercado de valores mobiliários apenas o conceito dos termos foi plasmado na norma legal, sendo detalhados os procedimentos e a operacionalização em dispositivos infralegais, essencialmente a D. CVM 390/01.

Entendeu-se ${ }^{235}$, então, previamente à detalhada disciplina trazida pela D. CVM 390/01, que os termos de compromisso acertados com a CVM deveriam atender aos requisitos, vigentes à época, para os compromissos de cessação celebrados com o CADE. Tais requisitos seriam (i) a especificação das obrigações assumidas, com o escopo de fazer cessar a prática investigada, no prazo estabelecido; (ii) o valor de multa diária, aplicável no caso de descumprimento; e (iii) obrigação de prestar contas, por relatórios periódicos, de sua atuação no mercado, mudanças em sua estrutura societária, atividades e localização ${ }^{236}$.

Parte da disciplina concorrencial dos termos de compromisso foi posteriormente inserida no contexto dos acordos com a Comissão de Valores Mobiliários, embora alguns itens, como a previsão de multa por inadimplemento, não tenham sido aproveitados. Especificamente quanto à inexistência de previsão de multa por inadimplemento, parece não ter causado prejuízo à efetividade dos termos de compromisso assinados com a CVM. Apenas em um caso $^{237}$, desde $1998^{238}$, em mais de 380 acordos, houve inadimplemento com a retomada do processo administrativo pela CVM.

Com relação às semelhanças, tanto o acordo com o regulador da concorrência quanto com o regulador do mercado de valores mobiliários independe de homologação judicial, em contraposição com o sistema norte-americano ${ }^{239}$.

\footnotetext{
${ }^{234}$ Além da disciplina legal, mais extensa que a oferecida pela Lei $6.385 / 76$, cumpre informar que o Regimento Interno, anexo à Resolução 1, aprovada pelo CADE em 29 de maio de 2012 ("RI-CADE") detalha, entre seus artigos 179 e 189, procedimentos e regras aplicáveis à análise e tramitação dos termos de compromisso perante tal autarquia.

${ }^{235}$ MORAES (1999, p. 105), entre outros que escreveram sobre o tema no intervalo entre a edição da Lei 9.457/97 e da D. CVM 390.

${ }^{236}$ Artigo 53, $\S 1^{\circ}$, da Lei 8.884/94.

${ }^{237}$ Acordo firmado em 22 de dezembro de 2000, em decorrência do Inquérito Administrativo CVM 04/99.

${ }^{238}$ O primeiro termo de compromisso foi firmado em 3 de junho de 1998, no âmbito do Processo Administrativo Sancionador CVM N. RJ 96/4025.

239 "Está previsto na atual legislação antitrust um termo de compromisso, a ser celebrado para a cessação de prática considerada ilícita. [...] Como se depreende do texto legislativo, o termo de compromisso previsto apresenta bases semelhantes às do consent decree, adotado no sistema norte-americano, dotando a autoridade administrava da simplificação que lhe é inerente, à medida que são suprimidas as fases procedimentais de instrução e julgamento do feito administrativo, sendo certo que, não cumprido o compromisso, o CADE passa a executar a multa cominatória prevista no termo de compromisso. A diferença consiste na celebração do termo de compromisso com a autoridade administrativa competente, sem a necessidade de homologação pelo Judiciário, como se dá com o consent decree, no sistema norte-americano". (MORAES, 1999, p. 103).
} 
Em relação à sua natureza e ao seu escopo, de forma assemelhada ao termo de compromisso oferecido à Comissão, o acordo com o CADE configura-se essencialmente como "instrumento de composição de conflitos, de caráter marcadamente negocial, que prioriza a rapidez e a efetividade da medida adotada à longa tramitação processual frequentemente necessária à aplicação da sanção, de cumprimento muitas vezes incerto" ${ }^{240}$. Ambos os institutos apresentam diferença de escopo em relação ao TAC (termo de ajuste de conduta), firmado com o Ministério Público, "que tem por fim a reparação do dano ao interesse difuso ou coletivo objeto da ação civil pública [...] [em contraposição ao] compromisso [...] [o qual] visa primacialmente à cessação da prática investigada, ou de seus efeitos lesivos [...]"241.

A seguir, serão ressaltados aspectos interessantes, identificados a partir da análise de proposta de acordo apresentada à autoridade concorrencial, acompanhada da identificação de ideias que possam ser adaptadas aos termos de compromisso celebrados com a CVM, especificamente quanto à avaliação, pelo órgão regulador do mercado de valores mobiliários, das propostas a ele submetidas.

\subsubsection{Considerações sobre o Voto do Conselheiro do CADE Luis Fernando Schuartz (Requerimento n. 8700.004221/2007-56)}

O então Conselheiro do CADE, Luis Fernando Schuartz, expôs, em sua manifestação em relação ao Requerimento n. 08700.004221/2007-56, apresentado nos autos do Processo Administrativo 08012.011142/2006-7, a racionalidade da análise das propostas de acordos substitutivos que lhe parecia mais adequada. Por tal entendimento, a decisão de aceitar o acordo seria adequada "se e somente se as consequências esperadas a ela associadas forem, desse ponto de vista exclusivamente, 'estritamente preferíveis' àquelas associadas à decisão de não celebrá-1o"242.

Prossegue o Conselheiro afirmando que a rejeição de uma proposta, por não ser a melhor possível para atendimento dos propósitos da administração, seria equivocada. Segundo ele, no julgamento da proposta não se deveria considerar a "melhor proposta possível", mas sim a proposta tal qual apresentada pelo interessado, promovendo-se uma

\footnotetext{
${ }^{240}$ CUEVA (2007, p. 288). Para outros argumentos para adoção dos termos de compromisso, que se misturam ao seu escopo, confira-se o item 6, infra.

${ }^{241}$ CUEVA (2007, p. 289).

242 Voto no Requerimento $08700.004221 / 2007-56$, no contexto do Processo Administrativo 08012.011142/2006-79, pp. 2-3, datado de 28 de novembro de 2007, disponível em <http://www.cade.gov.br/temp/D_D000000320991730.pdf, acesso em 01ago2012>, acessado em 29set2012.
} 
comparação dessa proposta - já apresentada - com a realidade fática subjacente ${ }^{243}$. Não deveria, portanto, proceder o administrador público à comparação entre a proposta apresentada e aquela que representaria o melhor acordo possível para a administração pública. Deve a autoridade avaliar e decidir se "celebrar o TCC tal como proposto é preferível a não celebrar o TCC tal como proposto, vale dizer, continuar litigando contra a proponente até um julgamento definitivo por parte do Poder Judiciário"244.

Portanto, segundo o relator, cuja opinião parece-nos acertada, a análise de possíveis acordos pelo órgão público deve ser fundamentada na comparação entre a situação decorrente do prosseguimento das investigações, com a rejeição do acordo, e o cenário a ser atingido com a aceitação da proposta tal como apresentada. Não deveria haver, pois, espaço para especulações teóricas a respeito do melhor acordo possível, do ponto de vista da administração e visando a preservação dos interesses por ela resguardados.

Segue o voto em exame com a apresentação do método para a comparação entre a realidade fática desconsiderando a proposta de acordo e a consequência da aceitação do compromisso proposto. Tal metodologia propõe a comparação da solução trazida pela proposta de compromisso com o provável resultado final do processo administrativo em que a proposta se insere. Criou, na ocasião, o Conselheiro um cálculo de "valor presente da sanção esperada", sendo a "sanção esperada" o resultado do "somatório das sanções em princípio mais prováveis para o tipo de conduta, multiplicadas pela probabilidade da sua aplicação [...] dado o conjunto probatório disponível”245.

$\mathrm{O}$ interessante raciocínio desenvolvido pressupõe recurso a duas probabilidades, sendo a primeira decorrente da identificação das punições frequentemente impostas aos responsáveis pelas condutas sob análise ${ }^{246}$. Seria possível mensurar, considerando os casos já julgados pela autoridade administrativa, quais as sanções usualmente determinadas, para cada tipo de comportamento considerado infrator. A outra avaliação probabilística envolveria a consideração dos elementos de prova à disposição da autoridade, para verificar as chances de aplicação das sanções anteriormente identificadas, no caso concreto. Como resultado das duas suposições, tem-se que "a sanção esperada é a

\footnotetext{
243 “[...] seria não somente irracional, mas também contrário aos interesses da Administração, rejeitar-se a proposta sob o argumento de que haveria outra proposta que lhe seria preferível, pois esta simplesmente não seria uma opção factível para a Administração. É verdade que restaria ainda a alteranativa abstrata de uma futura transação judicial supondo a prévia condenação administrativa". (voto citado, p. 3).

${ }^{244}$ Voto citado, p. 3.

${ }^{245}$ Voto citado, p. 3.

${ }^{246}$ Explicação pormenorizada, inclusive com exemplos, pode ser encontrada nas páginas 3-5 do voto em comento.
} 
média ponderada das sanções percebidas, em abstrato, enquanto mais prováveis para a espécie de infração, com os pesos sendo fornecidos pelas probabilidades de aplicação, em concreto, de cada uma dessas sanções" 247 .

A seguir, considerando que as decisões administrativas estão sujeitas à revisão judicial, que é praticamente certo que um agente econômico questionará qualquer decisão condenatória perante o Poder Judiciário, e que as medidas (inclusive pagamentos) derivadas do acordo concretizam-se imediatamente, "é necessário que sejam ambos trazidos ao mesmo instante do tempo através da aplicação de um fator de desconto", pois, para ser possível "efetiva comparação entre os ganhos associados ao pagamento da contribuição pecuniária no presente e ao pagamento da multa no futuro requer, deste último, o cálculo do valor presente" 248 .

Assim, utilizando conceitos de matemática financeira, o valor da sanção esperada é trazido a valor presente, considerando o prazo médio do processo administrativo e também do processo judicial, tendo em vista a já mencionada frequente contestação judicial das decisões administrativas pelos particulares punidos.

Sinteticamente, a racionalidade adotada na decisão do Conselheiro Schuartz considerou quatro aspectos como principais. O primeiro, a probabilidade de condenação, naturalmente considerando a hipótese de retomada do procedimento administrativo, em caso de recusa de acordo pela autoridade, temperada pela necessidade de consolidação de um conjunto probatório suficiente à decisão contrária ao administrado. O segundo, o tempo esperado até a decisão final no contexto administrativo, considerando uma média histórica de casos assemelhados, seguido pelo terceiro, a possibilidade de recurso ao Judiciário, com potencial obtenção de suspensão da sanção administrativa até uma decisão irrecorrível, com o retardamento da efetividade da decisão anteriormente proferida pela autoridade administrativa. O último aspecto é composto pelos termos do acordo: no caso concreto, o valor da contribuição que o proponente oferecia ao Fundo de Defesa dos Direitos Difusos, contraposto ao histórico de multas impostas, para condutas análogas à acusação que originou a proposta de acordo ${ }^{249}$.

Além dos pontos centrais referidos, no entender do proponente do mecanismo de julgamento da adequação de propostas ora analisado, deveriam impactar também a aceitação ou rejeição das propostas de termos de compromisso a "economia de custos

\footnotetext{
${ }^{247}$ Voto citado, p. 4.

${ }^{248}$ Voto citado, p. 5.

${ }^{249}$ A análise do voto em exame já foi realizada, entre outros, por SAMPAIO (2008), especificamente entre as páginas 250-251.
} 
sociais" potencial (custos públicos e privados empregados na continuação do litígio), e as "externalidades positivas", incluindo as "sinalizações positivas para todos os demais agentes econômicos que não são parte do processo quanto à eficácia no enforcement da legislação", os quais se colocam como importantes motivadores da adoção de acordos substitutivos $^{250}$.

Importante notar que o próprio idealizador do modelo para avaliação das propostas de termo de compromisso ora examinado não o define como "ótimo", mas como satisfatório, considerando o estado de desenvolvimento institucional em que se inseriu. $\mathrm{O}$ valor obtido pela fórmula não deve ser tomado como referência exclusiva para a avaliação, mas funcionar "como um standard inicial, ajustável dinamicamente à medida que progridam o conhecimento e a experiência",251.

Ocorre que, caso o valor mínimo aceitável para a suspensão de processos administrativos pudesse ser calculado com fórmula matemática exata, passaria a existir risco considerável do cometimento de infrações sempre que os agentes mensurassem os benefícios privados potenciais do cometimento de ilícitos e tais vantagens superassem a exposição máxima a que estariam sujeitos, aplicando o cálculo hipotético citado. A inexistência de uma "tabela de preços" pré-definida parece ser essencial para o funcionamento dos acordos substitutivos, e a possibilidade de adequação do compromisso oferecido, em cada caso específico, segue sendo item primordial para a utilidade do instituto.

\footnotetext{
${ }^{250}$ Conforme item 6, infra.

${ }^{251}$ Voto citado, p. 5.
} 


\section{ALTERAÇÃO DA LEI 6.385/76 PELA REFORMA DE 2001 - LEI 10.303/01 E DECRETO 3.995/01}

Em 2001 a Lei 6.385/76 foi alterada pela Lei n. 10.303 e pelo Decreto n. 3.995, ambos de 31 de outubro ("Lei 10.303/01" e "Decreto 3.995/01") 252. Os dois diplomas modificaram três dos parágrafos do artigo 11 da Lei 6.385/76, definidores da moldura legal aplicável aos termos de compromisso, conforme será abordado no presente item.

A primeira modificação na disciplina dos termos de compromisso firmados entre particulares e a Comissão, introduzida com a reforma de 2001, tratou de aprimorar a redação do parágrafo $5^{\circ}$ do artigo 11 da Lei 6.385/76, especificando que os procedimentos passíveis de suspensão em caso de celebração de termo de compromisso são aqueles "instaurados para a apuração de infrações da legislação do mercado de valores mobiliários". Da mesma forma, a nova redação substituiu o termo "indiciado" por "acusado", em referência aos agentes do mercado titulares do direito de submeter à administração uma proposta de acordo substitutivo. Ambas as mudanças parecem cosméticas, sem grandes efeitos, sendo pouco possível imaginar alguma alteração substancial na aplicação do instituto em razão de tais ajustes.

A última alteração no parágrafo $5^{\circ}$ tratou de inserir, expressamente ${ }^{253}$, que a suspensão dos procedimentos administrativos está condicionada ao exclusivo critério da Comissão, submetido à análise de enquadramento no interesse público. Essa reforma serviu, no mínimo, para explicitar e evitar polêmicas como as havidas no âmbito concorrencial, citadas no item imediatamente anterior, embora não fosse essencial a alteração da redação para que a celebração de termos de compromisso fosse entendida como faculdade da CVM, a qual deveria ser sempre exercida em atenção aos princípios da legalidade e da prevalência do interesse público, a serem observados pela administração pública (artigo 37 da CF/88 e artigo $2^{\circ}$ da Lei 9.784/99).

O segundo parágrafo do artigo 11 afetado pela alteração legislativa de 2001 foi o $7^{\circ}$, o qual, de acordo com a redação original, pretendia caracterizar como crime de desobediência, previsto no artigo 330 do Código Penal ${ }^{254}$, qualquer inadimplemento de

\footnotetext{
${ }^{252}$ Foge do escopo do presente trabalho analisar o curioso processo legislativo que acarretou a reforma da Lei 6.385/76 e da Lei 6.404/76 em 2001, pelos diplomas citados. Para informações sobre o tema, cf. CARVALHOSA e EIZIRIK, 2002.

253 "No que diz respeito ao termo de compromisso já previsto na Lei 6.385 (após a alteração realizada pela Lei $\mathrm{n}^{\circ} 9.457$, de 5 de maio de 1997) que possibilita a suspensão do procedimento administrativo, em qualquer fase, a reforma inclui dispositivo explicitando que tal termo será assinado a exclusivo critério da Comissão, se o interesse público o permitir". CHEDIAK (2002, p. 543), sem grifo no original.

254 "Desobediência. Art. 330 - Desobedecer a ordem legal de funcionário público: Pena - detenção, de quinze dias a seis meses, e multa".
} 
compromissário, após a assinatura do termo de compromisso com a Comissão. Considerando os reflexos do inadimplemento abordados de forma pormenorizada no item 9.2.11 infra, cumpre por ora apenas informar que, conforme análise da natureza dos acordos administrativos, estes não configuram "ordem legal de funcionário público". Assim, tendo o tipo penal como requisito justamente o descumprimento de ordem dessa natureza, impossível subsumir a ação de inadimplir um acordo à norma pretendida.

Pretendeu a alteração legislativa em exame, acertadamente, a descaracterização do inadimplemento do termo de compromisso como crime de desobediência, optando por reforçar a sua exequibilidade, determinando que o acordo firmado pelas partes constitua título executivo extrajudicial.

Por fim, o último ajuste empreendido pela reforma foi no parágrafo 10 do artigo 11, ao instituir que a CVM terá poder para regulamentar os termos de compromisso também nos procedimentos conduzidos pelas bolsas de mercadorias e futuros e entidades de compensação e liquidação de operações com valores mobiliários, em adição às bolsas de valores e entidades de mercado de balcão organizado, já previstas na redação original. Trata-se de ampliação do alcance e do reconhecimento dos acordos substitutivos como ferramenta para propiciar resposta ágil às necessidades do mercado, adaptando-o a outros órgãos, notadamente os autorreguladores.

Em síntese, a reforma legislativa teve pouca influência sobre os termos de compromisso e sua respectiva utilização. A sua faceta mais relevante aparenta ter sido a eliminação da referência ao crime de desobediência ${ }^{255}$, referência que poderia vir a repelir potenciais compromitentes, pela potencial exposição à imputação penal em caso de inadimplemento do acordo administrativo, ainda que fosse de discutível aplicabilidade. Efetivamente, não parece ter sido a reforma o motivo do incremento no volume de celebrações de termos de compromisso no período que a seguiu, mas sim a conjuntura econômica, de desenvolvimento do mercado de valores mobiliários brasileiro.

\footnotetext{
${ }^{255}$ Referido no item 5.
} 


\section{VANTAGENS DA CELEBRAÇÃO DOS TERMOS DE COMPROMISSO}

Considerando o já visto, é possível afirmar que a dinâmica do instituto objeto deste estudo, em breves palavras, consiste na obtenção da interrupção espontânea, pelo próprio administrado-investigado, da conduta suspeita de ilicitude, adicionada à também voluntária suficiente correção de danos, incluindo a plena indenização de prejuízos causados, sem que configure reconhecimento de culpa ou da ilicitude da conduta cessada. Tal ferramenta, alicerceada em estrita discricionariedade, pode contemplar também (e usualmente contempla ${ }^{256}$ ) o pagamento de quantia em moeda corrente pelo compromitente, com o objetivo de "desestimular a prática de condutas assemelhadas pelos próprios proponentes e demais participantes do mercado de valores mobiliários, em atendimento à finalidade preventiva do instituto do Termo de Compromisso"257.

O presente tópico planeja responder qual a utilidade do mecanismo acima explicado, e se tal utilidade é capaz de justificar a inclusão do instrumento no rol de ferramentas à disposição da Comissão de Valores Mobiliários, para desempenho de sua atuação fiscalizadora e, principalmente, sancionatória.

Para tanto, pretende-se inicialmente relacionar os benefícios auferidos pela administração pública - no caso, a CVM - com a celebração dos acordos substitutivos, em contraposição à trajetória tradicional de apuração e apenação de infrações administrativas. Em seguida, identificar os incentivos percebidos pelos agentes atuantes no mercado de valores mobiliários, constituidores de motivação para a difusão dos compromissos ${ }^{258}$.

Ressalte-se que a divisão metodológica dos benefícios para uma parte do acordo e para a outra serve unicamente ao propósito de maior clareza na exposição de cada um, vez que o conjunto de vantagens (para a administração e para o administrado) deve ser considerado de forma indissociável, como se faces opostas da mesma moeda ${ }^{259}$.

\footnotetext{
256 Considerando ter sido pago à Comissão, desde 2000 até o final do ano de 2011, valor superior a $\mathrm{R} \$ 245.000 .000,00$ (duzentos e quarenta e cinco milhões de reais), em pouco mais de 350 termos firmados até o final do mesmo ano. Fonte: relatórios anuais da Comissão de Valores Mobiliários, disponibilizados em <www.cvm.gov.br $>$, acesso em set2012.

${ }^{257}$ Conforme referido em diversos casos, v.g., na decisão do Colegiado de 19 de outubro de 2011, que aprovou proposta de termo de compromisso no curso do Processo Administrativo CVM N. RJ 2011/9734, em que três compromitentes acordaram o pagamento do valor total de $\mathrm{R} \$ 100.000,00$ (cem mil reais).

${ }_{258}$ Por serem tais benefícios os principais fundamentos da própria existência do termo de compromisso, e impulsionarem a sua utilização, merecerão especial aprofundamento, justificando a extensão deste item 6.

${ }_{259}$ As motivações a serem percebidas pelos compromitentes são, sempre, apresentadas em conjunto. STEINBERG (2009, p. 435) exemplifica os fatores que podem induzir a decisão de um acordo, em oposição ao litígio: "[...] the SEC may have a strong case, the financial costas involved in litigating with the Commission, avoidane of adverse publicity that would be generated by prolonged litigation, disruption of
} 


\subsection{Vantagens para a CVM}

Este tópico apresenta as motivações (todas interrelacionadas) da Comissão de Valores Mobiliários para aceitar e estimular a celebração de termos de compromisso como alternativa à via litigiosa.

Entre essas motivações é possível desde já destacar a busca por maior eficiência do sistema regulatório, cuja consequência é a manutenção da credibilidade do mercado de valores mobiliários entre seus participantes (atuais e potenciais); e pelo oferecimento de solução satisfatória à maior quantidade possível de questões e situações de potencial ilicitude de condutas, com a agilidade requerida pela natureza e dinamismo das operações ali (no mercado) efetuadas.

A atuação sancionatória típica da CVM, compreendida pelo julgamento administrativo acompanhado da aplicação de sanções rigorosas (multas e, principalmente, restrições ao exercício de direitos), parece ser mecanismo robusto o suficiente para desestimular a repetição de condutas, pelo mesmo agente ou por outros. Desestímulo esse impulsionado, primordialmente, pela publicidade do resultado dos julgamentos e a por sua repercussão no mercado. Fica evidente, diante disso, a "ameaça" de uma punição efetiva e substancial, capaz de produzir o efeito dissuasório desejado pela Comissão ${ }^{260}$.

Por outro lado, o caminho até tal resultado não é breve ${ }^{261}$ nem simples. E pior: é passível de contestação judicial (retardando ou mesmo extinguindo os efeitos de uma condenação administrativa), o que provoca a redução da efetividade de tais decisões, inclusive (e principalmente) em relação ao fator tempo da equação ${ }^{262}$.

normal operations that would otherwise result due to management's attention being diverted, and fear of offensive collateral estoppels should the SEC emerge victorious".

260 "Os instrumentos de que a CVM dispõe são poderosos e visam principalmente à tutela da informação. A fiscalização e a sanção, entre tais instrumentos, são aqueles que permitem a maior eficácia no exercício das funções da CVM. O aprimoramento da fiscalização, inclusive dotando-se a CVM dos elementos materiais necessários, a apuração rápida e a punição severa dos desmandos eventualmente cometidos no mercado [...] são bastantes para que a CVM alcance plenamente seu objetivo, constitucionalmente ordenado, de proteção da poupança popular e do investidor-consumidor de serviços no mercado de valores mobiliários". TRINDADE (2002, p. 325).

${ }^{261} \mathrm{O}$ intervalo médio compreendido entre a ciência das condutas pela CVM e o julgamento do processo administrativo sancionador (incluindo inquérito e investigação pré-processual), considerando um universo de 101 decisões proferidas entre 2000 e 2006, foi de 4,5 anos (ROSSI et. al., 2007, p.100).

262 "Agora, como a administração pública pode balizar o que deve ser objeto de termos de compromisso ou não? Eu acho que é justamente o juízo de conveniência e oportunidade da administração. O risco de anulação de uma decisão da CVM no Poder Judiciário é muito grande. O risco da própria absolvição, dentro da CVM, por falta de prova - muitas vezes obtida, ou não obtida, porque diabólica - é muito grande”. Declaração de Proença, p. 32 dos Cadernos Direito GV, Seminário 38, v. 7, n. 6, nov. 2010. 
Similarmente, apresenta-se como fator redutor da efetividade das ações sancionatórias a inexistência de poder de determinar a recomposição de prejuízos causados por um agente a outro, prerrogativa exclusiva do Poder Judiciário, o qual apresenta, em regra, respostas ainda mais demoradas do que a atividade administrativa.

As vantagens percebidas pela CVM com os termos de compromisso, portanto, devem ser avaliadas em comparação à chamada atuação sancionatória tradicional dessa autarquia $^{263}$.

O Parecer/CVM/PJU/005, de 10 de março de 1998, apresentado para explicar o então novo instrumento, trazia já em sua ementa que o compromisso firmado entre a CVM e os investigados em procedimentos administrativos "visa conferir maior efetividade e agilidade à atividade fiscalizadora desta autarquia"264.

Uma das maneiras de incrementar a agilidade desses procedimentos é a possibilidade de, em um período significativamente reduzido (em comparação, como se propôs, à decisão final administrativa $\left.{ }^{265}\right)^{266}$, interromper os efeitos potencialmente lesivos $^{267}$ e obter, do investigado, outras obrigações, entre as quais o pagamento de quantia compatível à obtenção do desestímulo à adoção de conduta assemelhada ${ }^{268}$, por ele próprio e por terceiros (em razão da publicidade dos acordos).

Colabora com a majoração da efetividade o fato de a adoção das medidas pelo compromissário ser voluntária e, aparentemente, irreversível. Desde que a CVM cumpra com a suspensão e arquivamento do processo em relação ao compromissário (uma vez atestado o adimplemento de todo o acordo), indenizações ofertadas a terceiros e o

\footnotetext{
${ }^{263}$ Colocando-se, sempre, como alternativa a ser avaliada: "Faz-se necessário, portanto, adotar uma concepção adequada do instituto, não como renúncia da função fiscalizadora (que aliás não deve jamais ser abandonada) ou da função punitiva, mas como meio alternativo do exercício do poder de polícia no âmbito do mercado de valores mobiliários". (Parecer/CVM/PJU/005, de 10 de março de 1998).

${ }^{264}$ Como observou o atual superintendente de fiscalização externa da CVM, Mário Luiz Lemos (2005, p. 12), "a CVM tem, quando cumpridos os requisitos legais necessários, a prerrogativa de promover acordo substitutivo, o Termo de Compromisso, entendido como uma flexibilidade no exercício do poder sancionador $[\ldots] "$.

${ }^{265}$ Repita-se, passível de revisão em âmbito administrativo (CRSFN) e judicial, sendo que a primeira é dotada de efeito suspensivo, nos termos do artigo 38 da D. CVM 538/08: "O recurso ao Conselho de Recursos do Sistema Financeiro Nacional terá efeito suspensivo".

266 "[...] privilegiando-se [...] uma solução mais rápida, que elimine os efeitos negativos de práticas não condizentes com as normas vigentes" Parecer/CVM/PJU/005, de 10 de março de 1998.

267 "É dito instrumento pró-efetividade, uma vez que cessam as ameaças ou lesões [...] caso as obrigações assumidas pelo administrado sejam cumpridas". DANTAS (2011, p. 106).

268 “[...] o compromisso deverá sempre visar à prevenção das irregularidades e à reparação dos prejuízos causados, mediante indenização substancial, comparável à reprovabilidade do ilícito". CUEVA (2007, p. 307)
} 
pagamento à Comissão ${ }^{269}$ como "condição para celebração do termo de compromisso"270 não parecem ser passíveis de restituição, a qualquer título.

Consequentemente, se o resultado do processo administrativo sancionador pode ser contestado em outra instância administrativa ${ }^{271}$ (com efeitos suspensivos até o julgamento, que usualmente demora mais do que o procedimento que levou à decisão proferida pela CVM) e, posteriormente, perante o Poder Judiciário, parece certo que o atendimento das obrigações pactuadas em sede de termo de compromisso é mais efetivo ${ }^{272}$, considerando o fator tempo - essencial à educação do mercado ${ }^{273}$ - se comparado à execução de sanção determinada pelo método tradicional ${ }^{274}$.

Nas palavras dos Professores Eros Grau e Paula Forgioni:

"O acordo viabiliza a efetiva aplicação das regras, um dos objetivos centrais da
regulação, ainda que os recursos disponíveis à Administração estejam sujeitos a
uma limitação. É ferramenta pela qual podem ser alcançados os resultados
desejados, de forma segura, sem que haja necessidade de canalizar recursos e
aguardar os prazos usuais para uma decisão em âmbito administrativo e, ainda
mais relevante, não sujeita a delongada discussão judicial para sua efetivação",275.

269 "Embora os TCCs que contenham cláusula obrigacional nesse sentido sejam enfáticos em afirmar que a contribuição pecuniária não tem natureza sancionatória, o fato é que tal mecanismo surge para que quantia, mesmo que inferior àquela fixada no final do processo sancionador responsabilidade administrativa, seja recolhida em tempo econômico". PALMA (2010, p. 258).

${ }^{270}$ Qualificação adotada mais recentemente, como, por exemplo, na apreciação do termo de compromisso apresentado para suspensão do Processo Administrativo Sancionador 05/2008, em reunião da Diretoria Colegiada realizada em 8 de novembro de 2011.

${ }^{271}$ O sistema de revisão das decisões da Comissão pelo CRSFN é alvo decríticas de DUBEUX (2006, pp.106-107): "A existência do duplo grau administrativo, no caso, implica desvantagens e incongruências. Traz evidente prejuízo à celeridade da atuação sancionatória, pois o trâmite processual prolonga-se por mais uma instância administrativa. Além disso, é fora de dúvida que o modelo de regulação independente da CVM - Presidente e Diretores com mandato fixo, após nomeação pelo Presidente da República e sabatina no Senado - queda inteiramente subvertido com a atuação revisora de um órgão que não goza nem da independência nem da legitimidade dos membros da CVM. Na verdade, a única vantagem que poderia ser argüida a favor do Conselho seria a segurança proporcionada pela atuação de mais uma instância revisora. Não há, todavia, nenhuma necessidade nesse sentido, porquanto a composição colegiada da CVM já é garantia institucional suficiente para a tomada de decisões ponderadas e adequadas".

${ }^{272}$ Ressaltando os benefícios dos acordos administrativos, DUBEUX (2006, p. 100) afirma que "A CVM, por sua vez, obterá a imediata cessação da atuação ilícita, o imediato ressarcimento dos prejuízos causados, além das demais obrigações assumidas pelo proponente".

273 “[...] a multa administrativa será efetiva se for devidamente recolhida, variando o grau de eficácia de acordo com o momento do recolhimento: a multa será tão ou mais eficaz quanto mais célere for o cumprimento da sanção pelo particular (satisfação espontânea x cumprimento de decisão judicial)" [e recurso ao CRSFN]. PALMA (2010, p. 258).

${ }_{274}$ Justificada, assim, a "relevância da celebração de compromisso entre a CVM e administrados para a regulação do mercado de capitais brasileiro, em especial por sua vocação para propiciar a cessação de práticas consideradas perniciosas e a célere indenização dos prejuízos decorrentes de tais condutas". TANJI (2009, p. 101).

${ }^{275}$ GRAU e FORGIONI (2005, p. 234). 
Além de o regulador conseguir interromper comportamentos indesejados e/ou recompor danos, de forma mais célere e segura do que pela tramitação de um processo administrativo, ainda há otimização no emprego dos recursos da Comissão ${ }^{276}$.

A suspensão do processo administrativo imediatamente após a celebração do termo $^{277}$ garante economia de tempo e recursos que seriam despendidos pela CVM na apuração daquela possível infração ${ }^{278}$. Isso faz, inclusive, com que os demais casos em que não há termo de compromisso sejam apurados de forma mais ágil, uma vez que ficam concentrados os esforços sancionatórios em um número menor de procedimentos, produzindo-se uma decisão com utilização de mais recursos do que se fossem todos os casos, levados à CVM, conduzidos até a decisão final ${ }^{279}$.

Assim, mesmo os casos em que a Comissão entender ser inoportuno ou inconveniente a pactuação de termos de compromissos, podem ser beneficiados pela adoção desse instrumento ${ }^{280}$.

Tal entendimento é bem sintetizado por Paulo Furquim de Azevedo ${ }^{281}$, ao analisar o cenário internacional dos acordos em processos relativos a condutas anticompetitivas e concluir que "há um consenso relativo no sentido de que tais acordos podem ser um meio eficiente para se encerrar com sucesso processos punitivos referentes a condutas uniformes, promovendo uma melhor alocação de recursos investigativos e

\footnotetext{
${ }^{276}$ A utilização do termo de compromisso "representará a restauração das condições normais do mercado, além da própria economia material decorrente da desnecessidade de prosseguimento e conclusão do processo administrativo". Parecer/CVM/PJU/6/1998.

277 Sobre o tema, o item 9.2.6, abaixo.

278 "O termo de compromisso surge para permitir ao regulador uma administração mais eficiente das atividades sancionadoras. Assim, mesmo que não se condene o jurisdicionado, se atingem fins considerados desejáveis". Voto apresentado pelo Diretor Otavio Yazbek em 19 de janeiro de 2011, no pedido de reconsideração em relação à decisão do Colegiado sobre proposta de termo de compromisso apresentada no Processo Administrativo Sancionador 2009/8316.

${ }^{279}$ EIZIRIK (2006, p. 37) apontava os acordos substitutivos entre particulares e a CVM como ferramenta para reduzir a quantidade de casos que são julgados pela CVM: "Com vistas a reduzir o número de processos sancionadores que são levados ao julgamento do colegiado, cumpre prestigiar o instituto do termo de compromisso, mediante o qual se extingue o processo sem julgamento de mérito, comprometendo-se o acusado a cessar a prática de atos que possam vir a ser considerados irregulares pela CVM ou a indenizar os eventuais prejuízos deles decorrentes”. Tal ideia parece ser acertada, pois com uma quantidade maior de acordos acarretando o encerramento prematuro dos processos administrativos sancionadores - desde que com termos adequados sob o ponto de vista de desestímulo às condutas e, principalmente, cessação de ações suspeitas de ilicitude e reparação de danos causados (não por acaso os requisitos essenciais indicados no item 4.3) - a Comissão poderá centrar seus esforços na instrução e julgamento das questões que entenda possam servir de norte ao mercado, ou aos agentes que não tenham interesse no ressarcimento dos terceiros lesados e da recomposição da situação prévia à conduta possivelmente lesiva.

${ }^{280}$ Aproveitando a experiência americana EIZIRIK (1998, pp. 264-265) previa exatamente tal efeito positivo dos termos sobre a atuação da administração pública: "O Departamento de Justiça, dessa forma, consegue solucionar uma maior quantidade de casos, tendo tempo e recursos para despender em outras demandas".

281 Excerto de voto proferido em 17 de dezembro de 2008, no julgamento do Requerimento 8700.004992/2007-43, no contexto do Processo Administrativo 08012.011142/2006-79, quando o autor citado cumpria mandato como membro do Conselho Administrativo de Defesa Econômica - CADE.
} 
processuais por parte das autoridades no aumento da detecção e punição de infratores à legislação". E segue, mais adiante,

\begin{abstract}
"Argumenta-se que tais acordos podem permitir uma maximização do efeito dissuasório [...] por promover melhor aproveitamento dos recursos existentes. Assim, mesmo que o acordo envolva uma pequena redução da sanção para o infrator que o celebra, os recursos públicos economizados podem ser utilizados na detecção e processamento de novos infratores, aumentando, assim, a punição e o efeito dissuasório tomados como um todo". (pp. 9 e ss.).
\end{abstract}

Percebe-se que a citação acima é permeada por interessante racionalidade econômica. Os meios (humanos e materiais) à disposição da administração pública são, naturalmente, finitos. Particularmente em nosso país, são por vezes escassos. Os acordos administrativos podem, então, maximizar o resultado da aplicação desses recursos, propiciando à Comissão maior eficiência em sua atividade regulatória, sempre em comparação à atuação pelos inquéritos e processos sancionadores.

Ainda sobre a redução do total de processos sancionadores decididos administrativamente, é até intuitivo que a aceitação de propostas de termos de compromisso pela CVM reflita na quantidade de casos julgados ${ }^{282}$. Quanto maior a quantidade de procedimentos encerrados em razão do arquivamento em relação à totalidade dos investigados, menor será a quantidade de casos conduzidos pela área técnica da Comissão até a submissão a julgamento pelas Superintendências e/ou pela Diretoria dessa autarquia. Registra-se a existência de afirmações no sentido de que uma menor quantidade de casos levados a julgamento configuraria, por si só, em uma vantagem dos termos de compromisso ${ }^{283}$, o que requer aprofundamento.

Realmente, é possível perceber, pelos dados constantes da tabela abaixo, que em decorrência do cumprimento dos termos de compromisso, um número não desprezível de processos administrativos sancionadores tem sido direcionado aos arquivos da Comissão anualmente, sem necessidade de conclusão da instrução e ocorrência de um julgamento ${ }^{284}$. Supondo que inexistissem tais acordos, caberia à CVM analisar e decidir a

\footnotetext{
282 "Sem dúvida, a adoção deste instrumento implica numa maior celeridade dos processos e na agilidade da autoridade administrativa no encerramento do processo punitivo, descongestionando os órgãos administradores e o Poder Judiciário". (MORAES, 1999, p. 109).

283 "A adoção de tal instrumento jurídico apresenta, no mínimo, duas grandes vantagens - a primeira consiste em favorecer o descongestionamento do julgamento de processos administrativos". (MORAES, 1999, p. 99).

284 "Passados mais de dez anos da introdução do instituto em tela, é possível constatar que a solução consensual dos procedimentos administrativos de natureza sancionadora tem se revelado um importante instrumento de efetiva implementação dos mandatos legais conferidos à entidade reguladora do mercado de capitais. Além de viabilizar um rápido ressarcimento de investidores lesados por eventuais ilícitos administrativos, sem as delongas e os percalços de um processo judicial, a celebração de termos de
} 
respeito da totalidade dos casos (soma dos processos julgados e encerrados sem julgamento, pelos compromissos firmados), o que confirma o efeito de "descongestionamento".

\begin{tabular}{|c|c|c|c|c|c|}
\hline Ano & $\begin{array}{c}\text { Processos } \\
\text { administrativos } \\
\text { julgados }\end{array}$ & $\begin{array}{c}\text { Termos de } \\
\text { compromisso } \\
\text { aprovados }\end{array}$ & $\begin{array}{c}\text { Processos } \\
\text { encerrados por } \\
\text { compromisso } \\
\text { de 100\% dos } \\
\text { investigados }\end{array}$ & $\begin{array}{c}\text { Arrecadação com } \\
\text { termos de } \\
\text { compromisso } \\
\text { (apenas } \\
\text { pagamentos à } \\
\text { CVM) - R\$ }\end{array}$ & $\begin{array}{c}\text { Representatividade } \\
\text { do valor arrecadado } \\
\text { em relação à } \\
\text { arrecadação total } \\
\text { da CVM - \% }\end{array}$ \\
\hline 2006 & 131 & 19 & 27 & $1.137 .262,62$ & $0,83 \%$ \\
\hline 2007 & 82 & 64 & 35 & $12.521 .899,68$ & $7 \%$ \\
\hline 2008 & 42 & 64 & 47 & $5.221438,40$ & $2 \%$ \\
\hline 2009 & 60 & 72 & 30 & $8.634 .496,75$ & $4,6 \%$ \\
\hline 2010 & 53 & 57 & 24 & $45.897 .860,10$ & $19 \%$ \\
\hline 2011 & 31 & 45 & 22 & $169.221 .219,00$ & $43 \%$ \\
\hline
\end{tabular}

Fonte dos dados utilizados: Relatórios Anuais e Relatórios de Gestão da Comissão de Valores Mobiliários, disponíveis em <http://www.cvm.gov.br/port/redir.asp?subpage=relatorio $>$. Acesso em 8 set2012.

Ainda que sob o ponto de vista de alocação dos recursos materiais e humanos pareça ser essa certamente uma vantagem ${ }^{285}$, não necessariamente, porém, uma quantidade menor de casos para julgamento pela Comissão de Valores Mobiliários revela-se verdadeiro benefício, sob o ponto de vista da eficiência regulatória. É necessário avaliar se os casos não julgados (arquivados pela celebração e adimplemento de acordo) foram endereçados corretamente, de forma a satisfazer os objetivos da atuação da Comissão e, por via reflexa, da utilização do termo de compromisso. Em caso positivo, o efeito é sobremaneira interessante à atividade de supervisão e disciplina do mercado, como verificado. Em caso negativo, porém, todas as potenciais vantagens do termo de compromisso são desperdiçadas, e apenas a aceleração na velocidade para definições em

compromisso diminui os custos e esforços tendentes a interromper ou coibir práticas ilícitas levadas a efeito, conduzindo a um célere e eficiente encerramento de procedimentos administrativos, inclusive em razão de o acusado ou investigado não precisar reconhecer a sua culpa ( $\$ 6^{\circ}$ do art. 11 da Lei $\left.n^{\circ} 6.385 / 76\right)$ ". WELLISCH e SANTOS (2009, p. 7).

285 “[...] há o viés pragmático da consensualidade, que se relaciona à governança pública e a instrumentalização de seus mecanismos de operacionalização (eficiência). Segundo essa perspectiva, os acordos administrativos consistem em efetivas válvulas de escape a determinadas disfuncionalidades da atuação administrativa típica, de forma que a atuação concertada pela Administtração pode-se mostrar mais eficiente no caso concreto quando comparada com os provimentos imperativos e unilaterais". PALMA (2010, pp. 128-129).

“A visão primeira é a indenização. [...] O outro aspecto, até egoístico da autarquia, é porque nós não conseguimos dar conta de todos os processos que existem lá dentro, além de todos os fatos da vida que acontecem.” Declaração do Dr. Eli Loria, grafada na p. 36 dos Cadernos Direito GV, Seminário 38, v. 7, n. 6, nov. 2010. 
relação aos casos não deveria, por si só, justificar a aplicação dos acordos administrativos. Devem ser aliados, neste ponto, forma e conteúdo, buscando confirmar o benefício sugerido $^{286}$.

Conclui-se, portanto, que a ferramenta apresenta, potencialmente, melhorias notáveis à atividade da Comissão de Valores Mobiliário, cuja confirmação depende essencialmente da correta aplicação de tal mecanismo. Em uma frase: acordos entre os administrados [investigados ou acusados] e a administração devem ser feitos "se e somente se ampliarem a dissuasão de práticas" consideradas prejudiciais ou lesivas ao mercado ${ }^{287}$.

Para que o efeito dissuasório seja alcançado, é necessário que alguns requisitos sejam satisfeitos ${ }^{288}$. Entendendo-se o enforcement das regras de preservação da lisura das condutas no mercado de valores mobiliários, por parte da CVM, como "a sua capacidade de restringir e orientar comportamentos dos administrados, mais especificamente coibir condutas” ${ }^{289}$, não parece incorreto afirmar que tal enforcement possa ser aprimorado, na condução da apuração de supostas ilicitudes, pela prevenção de comportamentos assemelhados.

É possível imaginar redução na quantidade de infrações ${ }^{290}$ caso a CVM consiga demonstrar ao mercado que atos ilícitos (ou mesmo supostamente ilícitos, considerando a inexistência de julgamento referida anteriormente, para os casos de compromissos) não serão tolerados. São, ao contrário, identificados, fiscalizados e apurados, tendo como resultado (i) a apenação administrativa daqueles cuja ilicitude fique comprovada; ou, como alternativa de igual poder inibidor de condutas indesejadas, (ii) a possibilidade de o administrado interromper tais condutas e recompor a totalidade dos prejuízos causados,

\footnotetext{
${ }^{286}$ Para alcançar o resultado projetado por CUEVA (2007, p. 302): “[...] a utilização criteriosa do termo de compromisso pode contribuir decisivamente para o combate às infrações ao mercado de capitais de modo mais rápido e eficiente que a aplicação da sanção ao final do processo administrativo".

${ }^{287}$ Citação adaptada do Voto de 2008 do Conselheiro Paulo Furquim de Azevedo, relator do Requerimento 8700.004992/2007-43, no contexto do Processo Administrativo 08012.011142/2006-79, conduzido pelo CADE, p. 12.

288 "A sanção administrativa tem forte componente dissuasório. Pela aplicação de uma medida sancionatória específica ao particular após apuração da responsabilidade administrativa em regular processo sancionador, os demais agentes do mercado reconhecem a resposta aflitiva pública à infração administrativa, gerando um incentivo negativo à realização de práticas infracionais. Em suma, reconhece-se que a sanção administrativa traz por principal efeito a prevenção de infrações dado o efeito simbólico que dela resulta aos particulares em geral. [...] [Alternativamente, com os TCs a autoridade] dissuade os demais agentes de mercado a realizar a conduta objeto do acordo consensual. [...] atrela o efeito dissuasório à capacidade de a autoridade administrativa emitir resposta à conduta no menor tempo possível”. PALMA (2010, p. 257).

${ }^{289}$ Voto de 2008 do Conselheiro Paulo Furquim de Azevedo, relator do Requerimento 8700.004992/2007-43, no contexto do Processo Administrativo 08012.011142/2006-79, conduzido pelo CADE, p. 11-12.

${ }^{290}$ Mantidas idênticas todas as outras variáveis, como a quantidade de agentes no mercado e a quantidade de operações efetuadas por tais agentes. Uma das dificuldades de analisar os dados disponibilizados em relação às infrações e às regras do mercado de valores mobiliários é isolar as mudanças econômicas, que "causam" maior ou menor quantidade de operações em tal mercado.
} 
com o escopo de evitar julgamento em âmbito administrativo e sofrer as consequências indicadas no item (i).

Assim sendo, os termos de compromisso podem auxiliar a Comissão na sinalização da existência de vigilância e acompanhamento dos agentes no mercado, e indicação de que comportamentos prejudiciais receberão resposta sancionatória. Nas palavras de DUBEUX (2006, p. 101), “a assinatura rápida de termo de compromisso deixa evidente para o mercado a atuação rápida e efetiva da CVM"291, na pressuposição de que o pactuado no compromisso seja satisfatório ao atendimento da função dissuasória.

O acordo substitutivo, que "tem por objetivo a preservação do ambiente [...] por meio da assunção, pelo proponente, do compromisso" 292 - cujo resultado pode vir a ser mais satisfatório à atividade de regulação do que a apuração sancionatória tradicional -, pode colaborar para melhorias no cumprimento das regras do mercado de valores mobiliários ${ }^{293}$, por possibilitar à Comissão "sinalizações positivas para todos os demais agentes econômicos que não são parte do processo quanto à eficácia no enforcement da legislação" 294 .

Um agente econômico, ao comparar os benefícios auferidos com infração a determinada regra com os riscos de sofrer determinada sanção, caso sua conduta seja identificada e apurada pelas autoridades do mercado em que atue, racionalmente tenderá a se afastar da perpetração do ilícito na mesma cadência em que perceba ser mais rápida e certa a punição à qual estará sujeito. $\mathrm{O}$ efeito dos acordos de, por via reflexa, propiciar à CVM atuação mais ágil em relação a um número superior de casos auxilia em um dos fatores indicativos de sua eficiência: o oferecimento de resposta sancionatória às ilicitudes em prazo menor.

O "efeito educativo e preventivo para os participantes do mercado",295, o qual deve ser perseguido pela Comissão na apuração de infrações às regras do mercado de

\footnotetext{
291 PALMA (2010, p. 258) constata que "resta mais evidente a resposta pública à conduta praticada pelo compromissário com imediato recolhimento de valor pecuniário, o que contribui para o aumento do efeito dissuasório do compromisso de cessação em imediata resposta à sociedade".

${ }^{292}$ DANTAS (2011, p. 106).

${ }^{293}$ Assegurar o cumprimento das regras, apontou EIZIRIK (1977, p. 56), coloca-se como um dos pilares da atividade regulatória, essencial ao desenvolvimento do mercado "é evidente que um dos objetivos básicos da regulação deve ser manter ou recuperar a confiança do público no mercado, basicamente no sentido de o investidor poder crer que seus retornos em aplicações no mercado de capitais estarão razoavelmente relacionados aos seus riscos. Deve também poder confiar na integridade financeira das instituições e nas informações divulgadas sobre os títulos e sociedades emissoras".

${ }^{294}$ Argumento de Luis Fernando Schuartz, apresentado no documento comentado no item 4.5.1.

295 Terminologia utilizada na própria Lei $6.385 / 76$, em seu artigo $9^{\circ}$, parágrafo $4^{\circ}$.
} 
valores mobiliários ${ }^{296}$, é sinônimo do efeito dissuasório mencionado. Estabelecendo tal objetivo, o "legislador reconhece que a pena no mercado de capitais visa evitar a prática de novos ilícitos, funcionando como instrumento de segurança social e defesa da sociedade" 297 . Parece adequado interpretar que o termo de compromisso, substitutivo à sanção administrativa, serve ao mesmo objetivo.

Quanto à efetividade da ferramenta, devemos notar também que a quase totalidade dos termos de compromisso firmados foi adimplida pelos agentes do mercado de valores mobiliários ${ }^{298}$. Até meados de 2012, apenas um entre mais de 380 acordos foi descumprido, o que significa que praticamente tudo o que foi acordado entre a CVM e os particulares foi concretizado, incluindo o ressarcimento a terceiros e pagamento à $\mathrm{CVM}^{299}$ de valores superiores a muitas das multas aplicadas em processos sancionadores.

O mesmo não é possível concluir a respeito das decisões administrativas da CVM. E é sabido que a demora na decisão administrativa pode atrapalhar a dinâmica do mercado, que demanda decisões rápidas e eficazes, concluindo-se, em situações extremas, que "a decisão administrativa tomada em descompasso com o ritmo do mercado pode colocar em risco a eficácia de seu conteúdo" ${ }^{\text {300 }}$.

A título exemplificativo, é possível fazer referência ao Processo Administrativo Sancionador CVM n. 06/07, julgado em 28 de setembro de 2010, cuja decisão determinou inabilitações, suspensão de registro e multas em valor total superior a R \$ 500.000.000,00 (quinhentos milhões de reais). Além da possibilidade de apresentação de recurso com efeito suspensivo ao CRSFN (inexistindo notícia de julgamento de recursos, até o final de 2012), havia a possibilidade de questionamento judicial do processo administrativo que levou à decisão ${ }^{301}$, o que de fato foi feito.

\footnotetext{
296 "No exercício de seu mister, a CVM deve atuar não só repressivamente, mas também preventivamente, isto é, de maneira a impedir a ocorrência de ilícitos no mercado, resguardando, assim, o interesse dos investidores potencialmente lesados". EIZIRIK et. al. (2008, pp. 255-256).

${ }^{297}$ CARVALHOSA e EIZIRIK (2002, p. 513).

298 Sobre o cumprimento dos termos, PALMA (2010, p. 259) afirma que "Na qualidade de instrumento consensual, aperfeiçoado por meio de consentimentos recíprocos na negociação entre Administração Pública e administrado, o compromisso de cessação é caracterizado pelo cumprimento espontâneo das obrigações estabelecidas no termo. Trata-se de uma decorrência intrínseca à consensualidade: os acordos encerram a litigiosidade pelo cumprimento imediato das obrigações pactuadas, desde que mantidas as condições existentes à época da negociação. Dessa forma, o TCC se mostra ao CADE como interessante barreira à judicialização das decisões administrativas".

${ }^{299}$ Como condição da celebração de compromisso.

${ }^{300}$ PALMA (2010, p. 250).

301 "Não se trata de exame do mérito administrativo, mas pura aferição da legalidade do processo, passível de controle pelo Judiciário, relacionado à cláusula do devido processo legal", conforme registrado na Ementa do acórdão referido a seguir.
} 
Em 27 de junho de 2012, houve julgamento de recurso de apelação em mandado de segurança ${ }^{302}$ impetrado por um dos condenados administrativamente (condenado ao pagamento de multa em valor superior a $\mathrm{R} \$ 56.000 .000,00$ (cinquenta e seis milhões de reais), em que se decidiu pela "anulação do PAS CVM n. ${ }^{\circ}$ 06/2007, a partir do início da dilação probatória, bem como a determinação de realização da prova técnica requerida pelo impetrante, 303 .

Ainda que o valor da multa seja relevante, tanto considerada isoladamente quanto no contexto do Processo Sancionador que a originou, o resultado do seu questionamento judicial (ainda que talvez apenas temporário, vez que é possível, após a refeitura do processo administrativo, a aplicação de nova multa, de ordem de grandeza assemelhada) atenta contra a efetividade das decisões da Comissão ${ }^{304}$.

Por hipótese, caso (no momento oportuno, dentro do prazo regulamentar) fosse oferecido um termo de compromisso pelo acusado que questionou judicialmente a multa, comprometendo-se a cessar as condutas e a reparar os danos causados (aplicável na espécie, pois a condenação administrativa fundamentou-se na "prática de operações fraudulentas contra o patrimônio público"305), mesmo que o valor total compromissado não chegasse ao valor da multa acima referida, possivelmente tal acordo teria mais efetividade $^{306}$ enquanto reforço da posição de vigilância da CVM, dissuadindo condutas assemelhadas. Adicionalmente, seria evitado o desgaste institucional causado pela publicidade do caso, e não seria necessário alocar recursos para condução do litígio judicial e o retrabalho a ser feito, no âmbito do processo administrativo sancionador anulado ${ }^{307}$.

\footnotetext{
302 Apelação em Mandado de Segurança n. 0017585-47.2010.4.02.5101, julgada pela $7^{\text {a }}$ turma do Tribunal Regional Federal da 2a Região por unanimidade, em 27 de junho de 2012, Rel. José Antonio Lisboa Neiva. ${ }^{303}$ P. 27 do voto citado.

304 “[...] economia de custos com processos e litígio, bem como a redução da incerteza quanto à punição" são dois dos benefícios apontados no Voto do Conselheiro Paulo Furquim de Azevedo, relator do Requerimento 8700.004992/2007-43, no contexto do Processo Administrativo 08012.011142/2006-79, conduzido pelo Conselho Administrativo de Defesa Econômica - CADE (p. 9-10).

${ }^{305}$ Comunicado de divulgação do resultado do Processo Administrativo Sancionador N. 06/07, divulgado no website da CVM após o julgamento. Disponível em: <http://www.cvm.gov.br/port/infos/Comunicado\%20PAS\%20RJ\%2006-07\%20$\% 2028 \% 20 \mathrm{de} \% 20$ setembro\%20de\%202010.asp > , acesso em out2012.

${ }^{306}$ Dessa forma, resta mais evidente a resposta pública à conduta praticada pelo compromissário com imediato recolhimento de valor pecuniário, o que contribui para o aumento do efeito dissuasório do compromisso de cessação em imediata resposta à sociedade. PALMA (2010, p. 258).

${ }^{307}$ Em relação ao cenário concorrencial, os números não são muito diversos, como atesta SOUZA (2010, p. 111): “[...] o percentual de cumprimento [dos TCCs firmados com o CADE] é bastante próximo de 100\%. Essa, aliás, é uma das grandes demonstrações da efetividade da negociação, pois, no processo tradicional de cobrança de penalidades impostas pelo Cade de 2003 a 2008, por exemplo, apenas 18\% das obrigações foram cumpridas e apenas $11,47 \%$ do valor total inscrito em dívida ativa pela procuradoria do Cade foi efetivamente recolhido".
} 
Ampara-se na mesma conclusão - de benefício de tempo e recursos - a "Política da SDE - Termo de Compromisso de Cessação de Prática em Cartel", divulgada em fevereiro de 2008 pelo então Departamento de Proteção e Defesa Econômica da Secretaria de Direito Econômico ${ }^{308}$, com o escopo de informar os critérios a serem utilizados na análise de propostas de Termos de Compromisso de Cessação. Tal documento, em suas considerações iniciais, apresenta benefícios a serem percebidos pela coletividade tutelada pelo direito da concorrência no caso de acordos satisfatórios:

\begin{abstract}
“O primeiro benefício é a economia de tempo e recursos. Quando um investigado por prática de cartel celebra um TCC, os recursos e tempo que seriam utilizados para a investigação daquele envolvido serão economizados, o que na prática significa a liberação de parte dos escassos recursos disponíveis para o empreendimento de novas investigações. A economia de recursos para a Administração também se traduz pelo fato de que não haverá recurso ao Poder Judiciário por parte de tal investigado, liberando recursos que antes seriam usados em litígios judiciais. [...] Em terceiro lugar ${ }^{309}$, um TCC em caso de cartel possibilita o recolhimento imediato de contribuição pecuniária em benefício da sociedade". (p. 1, grifos no original).
\end{abstract}

Outra vantagem conferida à CVM pelos termos de compromisso é a possibilidade de ação - provocando os efeitos já referidos (interrupção de conduta e correção de irregularidades) - mesmo nos casos em que, ao final da fase investigativa, não possuir conjunto probatório robusto o suficiente ${ }^{310}$ para instruir um julgamento razoavelmente fundamentado para a condenação. ${ }^{311}$ Em tais casos a celebração de termo de compromisso tende a ser uma medida satisfatória para essa autarquia, em seu anseio de resguardar o mercado, pela qual o comportamento investigado é interrompido.

\footnotetext{
308 Tal estrutura, nos termos da nova organização do Sistema Brasileiro de Defesa da Concorrência reformulada pela Lei 12.529/11, foi absorvida pelo CADE. Não há, por ora, registro de nova divulgação de política para análise dos acordos substitutivos, mas não há razão para concluir que a lógica tenha sido alterada.

${ }^{309} \mathrm{O}$ segundo benefício não parece ser aplicável à grande maioria dos termos de compromisso celebrados com a CVM, pois trata da cooperação do investigado na instrução do processo administrativo. Considerando ser a suspensão do processo administrativo sancionador (ou inquérito) consequência direta da celebração dos termos de compromisso, uma hipótese em que algo parecido poderia ocorrer no mercado de valores mobiliários seria um procedimento investigativo em face de mais de um acusado, em que somente um propusesse termo, no qual uma das obrigações seria de municiar a CVM com informações capazes de auxiliar na instrução do procedimento, para julgamento do(s) administrado(s) que não participasse $(\mathrm{m})$ do acordo administrativo. Tal cenário pode ser configurado, também, alheiamente aos acordos administrativos, caso um dos acusados prestasse informações à autarquia sobre a materialidade do ilícito, ao amparo do parágrafo $9^{\circ}$ do artigo 11 da Lei 6.385/76.

310 “[...] compete à CVM, nos processos por ela instaurados, o ônus de provar os fatos caracterizadores do ilícito, bem como a responsabilidade do suposto infrator, sob pena de se ver obrigada a arquivar o processo e a absolver o indiciado". CARVALHOSA e EIZIRIK, 2002, p. 501.

${ }^{311}$ Vale ressaltar que, nos termos do artigo $8^{\circ}$ da D. CVM 538/08, apenas quando existirem elementos de autoria e materialidade da infração suficientes, uma superintendência poderá apresentar termo de acusação, peça inicial para a instauração de qualquer processo administrativo sancionador (conforme o parágrafo primeiro do mesmo artigo).
} 
Portanto, em um cenário como o descrito, existindo apresentação de proposta de termo de compromisso razoável pelo administrado (a quem cabe mensurar as possibilidades de condenação, e ponderar juntamente aos outros critérios e benefícios potenciais $^{312}$ sobre a conveniência de propor um acordo à CVM ou seguir com o processo administrativo) parece ser provável que os representantes da Comissão aceitem o acordo oferecido $^{313}$.

Nesse sentido, o instrumento mostra-se vantajoso por possibilitar tentativa de redução dos investimentos de tempo e pessoal em persecuções administrativas que tendam a ser infrutíferas, possibilitando aos agentes públicos dedicação à fiscalização e supervisão de casos ou temas mais importantes ou sensíveis. Trata-se, com reservas, da chamada "economia de custos sociais" potenciais ${ }^{314}$ (recursos públicos, no caso, empregados na continuação do processo sancionador) ${ }^{315}$.

$\mathrm{O}$ conjunto probatório necessário à obtenção de condenação administrativa justifica breve nota, complementar ao tema central do trabalho e especificadora das provas necessárias ao julgamento, possível argumento para a adoção de termos de compromisso pela Comissão de Valores Mobiliários.

Considerando a inserção da responsabilização de infratores às normas do mercado de capitais no contexto de apenação administrativa, tem-se que essa responsabilização deve ser individualizada e, geralmente, decorrer de culpa subjetiva dos agentes $^{316}$. Assim, em regra, faz-se necessária a descrição precisa tanto da conduta

\footnotetext{
312 Tratados no item 6.2, infra.

313 “[...] o termo pode ser muito mais interessante para a regulação do que a espera do desfecho de um processo administrativo sancionador, que demanda muito mais tempo e muitas vezes não consegue recolher as provas necessárias à apenação do infrator.” DUBEUX (2006, p. 100-101).

${ }^{314}$ Argumento de Luis Fernando Schuartz, apresentado no documento comentado no item 4.5.1.

315 Retomando a noção de potencialização do efeito educativo e preventivo das ações sancionatórias da CVM, que visa "permitir à CVM conferir prioridade na apuração de determinadas infrações de maior relevância, deixando em segundo plano ilícitos por ela considerados como de menor potencial ofensivo" (CARVALHOSA e EIZIRIK, 2002, pp. 513-514), casos de menor relevância, que não constituam prioridade na atividade de apuração das infrações pela Comissão (conforme artigo $9^{\circ}$, parágrafo $4^{\circ}$, da Lei 6.385/76), podem receber tratamento diferente dos demais, prioritários, de acordo com a política desejada pela Comissão. No mesmo sentido, é possível identificar o pensamento do Professor José Marcelo Martins Proença, exposto no evento registrado na edição já citada dos Cadernos Direito GV, Seminário 38, v. 7, n. 6, nov. 2010 (pp. 31-32), que julga ser interessante, sob o ponto de vista regulatório, a adoção dos termos de compromisso principalmente nas hipóteses de ausência de provas suficientes, ou de apuração de condutas não significativas, considerando o total global em que se insere.

316 "Em nosso entendimento, a imposição de sanção disciplinar a determinado sujeito passivo pressupõe a caracterização perfeita e fundamentada do elemento intencional, sem o qual não se configura a infração administrativa. [...] Em resumo, essencial nos afigura, em qualquer hipótese, que o julgamento da infração disciplinar se fundamente na culpa própria, concreta e individual de cada indiciado, à luz das circunstâncias de cada caso, não podendo sob nenhum pretexto prescindir da explicitação do elemento intencional do ilícito punido". GUERREIRO (1981, p. 75-77). Sobre o tema, acrescentem-se as palavras de LEÃES (2004, p. 1.442) e EIZIRIK (1992, p. 195), respectivamente: “A função repressiva do Estado não é válida quando os
} 
transgressora da norma quanto do comportamento do infrator, para que possa haver condenação administrativa. Não devem ser desprezados casos excepcionais, em que pode ocorrer inversão do ônus da prova, apuração objetiva da infração em razão de violação de deveres previstos na legislação, e até a presunção de culpa, excepcionais à regra geral descrita $^{317}$.

Para fins de registro, há também manifestações no sentido de que provas indiciárias ou indícios probatórios podem ser suficientes para condenação administrativa, conforme sustentado por OSÓRIO (2011, p. 410$)^{318}$ e por SANTOS ${ }^{319}$.

motivos do ato punitivo são determinados apenas por indícios. A imposição de sanção de polícia a determinado sujeito passivo pressupõe perfeita e fundamentada caracterização da culpa, sem a qual não se configura infração administrativa."; e "A responsabilidade administrativa dos indiciados em inquérito administrativo da CVM rege-se pelos princípios da responsabilidade subjetiva. Ou seja, incumbe à CVM demonstrar não só a conduta antijurídica como também o elemento subjetivo, ou seja, o dolo ou a culpa".

Confirma as assertivas doutrinárias reproduzidas acima a análise de julgados do CRSFN, segunda instância administrativa, tratando de temas de mercado de valores mobiliários e financeiro, empreendida por VIEIRA (2000, pp. 167-169), na qual o autor enuncia - após análise da tendência seguida pelas decisões - que "é subjetiva a responsabilidade no âmbito das normas tuteladas pelo Banco Central e pela CVM". Segundo o mesmo autor, "encontram-se, hoje, inúmeras decisões do CRSFN adotando de modo uniforme a teoria da responsabilização subjetiva, de modo a concluir que apenas responde indiretamente pelo ato ilícito administrativo aquele agente que nele esteja diretamente envolvido, concorrendo com culpa ou com dolo inequivocamente demonstrados pela autoridade fiscalizadora". (p. 167). Também a respeito da responsabilidade no âmbito do mercado de valores mobiliários, cf. SILVA (2006).

317 Pela clareza em relação ao assunto, vale a reprodução de excerto de texto de EIZIRIK (1992, p. 196): "Temos admitido, em certos casos, a inversão do ônus da prova, em matéria de responsabilidade administrativa, o que não significa, evidentemente, aceitação da responsabilidade objetiva, a qual somente pode defluir de disposição legal expressa e tendo em vista a reposição de danos, jamais cabível portanto em matéria de aplicação de medidas punitivas, quer na esfera penal, quer na esfera administrativa. [...] em outros [casos] em que ocorre violação a determinados deveres legalmente cometidos ao administrador da companhia (dever de informar, dever de diligência, dever de lealdade, todos estabelecidos na Lei das S.A.), é possível a apuração objetiva da infração, a qual se caracteriza independentemente do elemento intencional. É que em tais casos a responsabilidade civil e administrativa decorre de infração à lei, cabendo a recomposição dos prejuízos e a aplicação de sanções disciplinares mesmo sem a cabal comprovação da intenção de lesar, do dolo, bastando portanto a configuração de culpa em sentido estrito. E a culpa pode ser presumida quando o infrator, por desenvolver uma atividade sujeita à disciplina jurídica especial, tinha o dever de informar-se sobre suas obrigações legais, regulamentares e estatutárias". No mesmo sentido, LEÃES (1982, p. 177).

318 "O Direito Administrativo Sancionador é especialmente receptivo à prova indiciária, ou aos indícios enquanto meios probatórios, até porque essa modalidade de prova é fundamental no estabelecimento de pautas de 'razoabilidade' dos julgamentos. No fundo, a razoabilidade do decreto condenatório é muito mais importante do que a suposta 'certeza' subjetiva absoluta do julgador. [...] No campo das responsabilidades sancionatórias, cabe aduzir que os indícios podem ser suficientes para uma condenação, especialmente no terreno de aplicação do Direito Administrativo repressor, embora até mesmo no Direito Penal isto seja possível, justificadamente".

${ }^{319}$ Em declaração reproduzida na matéria "CVM já considera indícios como provas em processos", veiculada pela revista eletrônica Consultor Jurídico, em 24 de setembro de 2012, Alexandre Pinheiro dos Santos, Superintendente-geral da CVM, ao comentar o julgamento da Ação Penal 470, julgada pelo STF, afirmou que "Para nós é positivo que num julgamento com essa visibilidade em termos jurídicos esteja ocorrendo uma discussão com tanta clareza, mostrando como é natural lidar com esse tipo de prova", e que "desde que exista um conjunto de indícios sérios e convergentes, o colegiado [da autarquia] poderá, como já fez em diversas oportunidades, condenar alguém por uso de informação privilegiada. Ainda que não se consiga precisar como ou por meio de quem o sujeito teve acesso à informação". Disponível em 〈http://www.conjur.com.br/2012-set-24/comissao-valores-mobiliarios-considera-indicios-provas-processos〉, acesso em out 2012 . 
Outra vantagem da celebração de termos de compromisso, identificada por SADDI - que inclusive propaga a necessidade de adaptação do instituto para aplicação nos processos administrativos conduzidos pelo Banco Central do Brasil, que ainda hoje ${ }^{320}$ não dispõe de tal espécie de ferramenta de enforcement ${ }^{321}$ - seria evitar o "dilema kafkaniano". Este consiste, segundo o autor, na condenação em esfera administrativa seguida de absolvição no âmbito judicial, e vice-versa. O termo de compromisso poderia evitar situações nas quais, após aplicação de sanções administrativas (multas, restrições ao desempenho de atividades, danos à reputação), sobreviesse absolvição final, perante o Poder Judiciário ${ }^{322}$.

Além de a composição excluir a apreciação da responsabilidade administrativa pelo Judiciário, cujo resultado pode não ser o esperado pelas partes, a definição prévia das obrigações a serem assumidas pelos signatários, limitadas pelas cláusulas do termo de compromisso, assegura a redução das incertezas, tanto por parte da administração como do investigado, e representa vantagem adicional em relação à atuação sancionatória

320 Conforme confirma recente decisão do CRSFN (Recurso n. 11405, originado do Processo BCB 0301208300, julgado em 27 de abril de 2011), em que os conselheiros confirmaram afirmação do BCB: "Quanto ao pedido de realização de termo de compromisso, esclareça-se que não cabe, vez que o processo administrativo instaurado pelo Banco Central do Brasil segue o rito da Resolução 1.065/85, em que inexiste tal previsão". Por seu turno, o parecer da Procuradoria Federal da Fazenda Nacional concluiu que "o pleito de celebração de Termo de Compromisso não encontra a indispensável descrição normativa no âmbito do Banco Central do Brasil. Não há, na legislação de regência, previsão equivalente à inscrição constante do art. 11, § $5^{\circ}$, da Lei $n^{\circ} 6.385 / 76$, sendo certo que esse dispositivo tem alcance limitado aos processos em julgamento perante aquela autarquia".

${ }^{321}$ Conclusão semelhante é alcançada por CUEVA. Tal pleito não é novo, sendo registrado já no Relatório de Atividades do Conselho de Recursos do Sistema Financeiro Nacional de 1998, disponível em http://www.bcb.gov.br/crsfn/rel1998/apresent.htm. Em tal documento, datado de 12 de abril de 1999 e subscrito pelo Secretário-Executivo do órgão, Marcos Martins de Souza (que até hoje desempenha tal função), apresenta a opinião de que "À semelhança do Conselho Administrativo de Defesa Econômica CADE, autarquia vinculada ao Ministério da Justiça, e da própria Comissão de Valores Mobiliários - CVM, seria de extrema importância, por exemplo, que o ordenamento legal abrisse ao Banco Central a possibilidade de o órgão valer-se do compromisso de cessação. Trata-se de instituto de vanguarda que, ensejando a cessação da prática delituosa, infrativa, sem implicar formal assunção de culpabilidade da parte do agente, tudo estampado em documentos firmados nesse contexto perante a autoridade oficial, traz imediatos e efetivos benefícios para o mercado, quando se pondera que os resultados pretendidos pelos mecanismos repressores levam tempo e nem sempre se concretizam satisfatoriamente."

Existiram tentativas, entre as quais é possível citar o Projeto de Lei Complementar n. 47, de 1991, conforme substitutivo apresentado em 13 de maio de 1997, e o Projeto de Lei Complementar n. 129, de 2004, que objetivavam, entre outras alterações no Sistema Financeiro Nacional, possibilitar a aplicação do instituto do termo de compromisso aos procedimentos administrativos conduzidos pelas "Entidades de Fiscalização e Supervisão do Sistema Financeiro Nacional", de forma muito assemelhada ao acordo objeto do presente estudo (inclusive estando presentes conceitos centrais, com requisitos similares, inexistência de confissão ou reconhecimento de ilicitude e suspensão do trâmite na constância do cumprimento do acordo, com eventual retomada em caso de inadimplemento pelo administrado).

Por outro lado, SOUZA (2010, p. 113-114) defende que independe de previsão legal específica, mas apenas de disciplina pelo CMN, em razão da previsão do artigo $4^{\circ}$, VIII, da Lei n. 4.595 , de 31 de dezembro de 1964.

322 SADDI (2000, p. 62). 
tradicional $^{323}$. Mesmo um agente seguro e certo em relação a seus argumentos e a seu direito pode ser surpreendido por decisão em sentido diametralmente oposto à esperada, proferida pelo Judiciário ${ }^{324}$.

Por fim, não deve ser olvidado que o mais importante benefício garantido pela atuação da CVM na celebração dos termos de compromisso ${ }^{325}$, a ser firmado apenas quando conveniente e oportuno ${ }^{326}$, considerando os objetivos da própria atividade regulatória dessa autarquia ${ }^{327}$, é assegurar a um terceiro prejudicado um efetivo e ágil

323 Segundo a ex-conselheira do CADE Neide Mallard, o compromisso "tem por objetivo a imediata restauração da concorrência, sem as delongas do processo administrativo, poupadas as démarches das ações judiciais, evitando ainda os altos custos financeiros normalmente infligidos a todas as partes envolvidas. É inequívoca a desejável redução da incerteza no processo". MATTOS (1997, pp. 44-45).

${ }^{324}$ Sobre as decisões proferidas pelos membros do Poder Judiciário em relação aos temas afeitos ao direito societário e mercado de capitais, cf. ARAGÃO, 2006.

${ }^{325}$ Já referido no item 6.1 .

${ }^{326}$ Há particulares que não compreenderam a discricionariedade citada. Exemplificativamente, é possível citar o pedido de reconsideração apresentado em relação à rejeição, pela Diretoria Colegiada, de proposta apresentada pelos acusados no Processo Administrativo Sancionador RJ n. 2011/9398, no qual os acusados apresentaram como argumento, entre outros, que "a decisão de celebração ou não de termo de compromisso não pode ser pautada em juízo discricionário, devendo-se, ademais, a Administração Pública adotar a opção mais favorável ao administrado; e 'a desproporcionalidade da decisão [tomada pelo Colegiado em 4.10.2011] evidencia-se na medida que a Procuradoria Jurídica já havia, inclusive, emitido parecer sinalizando quanto à legalidade e proporcionalidade da proposta".. No voto condutor do julgamento, o Diretor Otavio Yazbek explica que "não há, para os acusados, qualquer direito subjetivo quanto à celebração de termo de compromisso", e que a decisão de aceitar ou não proposta de acordo deve passar pela análise de sua conveniência e oportunidade, sendo condicionada aos "balizamentos expressamente previstos na própria Lei n. ${ }^{\circ}$ 6.385/1976, na Deliberação CVM n. ${ }^{\circ} 390$, de 8.5.2001 e outros relacionados à política regulatória”. (Excerto transcrito do Relatório apresentado em 28 de fevereiro de 2012, tratando do referido pedido de reconsideração).

O recurso apresentado evidencia que as questões básicas a respeito do tema, entre as quais a discricionariedade da Comissão em aceitar ou não a proposta, não são claras a todos os agentes do mercado e seus assessores jurídicos. É possível notar, a partir da fundamentação do pedido de reconsideração, que há quem ignore, inclusive, a função da Procuradoria Federal Especializada em relação à análise de legalidade, e que a decisão cabe exclusivamente à maioria da Diretoria Colegiada, não sendo tal órgão sequer vinculado ao parecer oferecido pelo Comitê de Termo de Compromisso, cujo papel, como visto, é de suporte.

${ }^{327}$ Vale registrar interessante síntese elaborada por PAULIN (p. 155): “O órgão de supervisão no mercado de capitais, no exercício do respectivo poder de polícia, não está obrigado a impor sanção a cada irregularidade que constate. A lei permite que o supervisor se valha de diversas alternativas. Destarte, mesmo diante da existência de um ilícito administrativo, ou de indícios bastante veementes de sua ocorrência, à Administração é facultado usar mecanismos não repressivos e até de composição, ao invés de lançar mão das tradicionais medidas sancionadoras. A prática tem apontado que, quando bem utilizados, os instrumentos não punitivos apresentam grau de eficácia elevado. Exemplo típico é o termo de compromisso. No passado, embasado em preconceitos, muitos colocaram em dúvida a conveniência de sua adoção. Decorrido algum tempo, desde a entrada em vigor da Lei 9.457/97, os resultados são animadores. Comprovou-se aqui aquilo que já se sabia alhures, ou seja, que a composição com o acusado, muitas vezes, é extremamente útil para o bom e regular funcionamento do mercado. Agregue-se que seu emprego está em linha com o princípio da eficiência, que deve ser continuamente perseguido pela Administração. Se o aparato não sancionador é uma possibilidade que se coloca, isto não significa que a sanção tenha perdido sua razão de ser. Casos há que, devido às circunstâncias, a imposição de pena é de rigor. Inconcebível, pois, na atual fase do mercado de capitais brasileiro, imaginar que órgão de supervisão possa ser desprovido de seu instrumental punitivo". 
ressarcimento de danos sofridos em decorrência de infrações às normas do mercado, independentemente de decisão judicial e com o consenso do agente indenizador ${ }^{328}$.

\subsection{Vantagens para o administrado}

A credibilidade, refletida na certeza dos agentes atuantes no mercado de valores mobiliários, de que as regras existem devem ser seguidas e, caso sejam desobedecidas, incidirão sanções, constitui alicerce indispensável ao desenvolvimento desse mercado. A segurança de que os riscos estarão confinados às operações, e não se propagam para as regras do jogo, é essencial para que seja possível o amadurecimento do mercado de valores mobiliários - uma das principais formas de financiamento da atividade econômica.

Para os participantes em atividade no mercado, uma reputação ilibada é requisito importante para possibilitar que terceiros negociem com eles ou, ao menos, negociem com mais segurança e menores restrições ${ }^{329}$. Em tal sentido, a manutenção da estabilidade do renome do agente perante os demais é buscada por todos os participantes $^{330}$.

A preservação reputacional é, assim, o primeiro dos benefícios auferidos com os termos de compromisso pelos investigados em procedimentos administrativos da CVM. Por esse mecanismo, os indivíduos e entidades atuantes no mercado de valores mobiliários podem evitar condenações administrativas e a publicidade negativa delas decorrentes, mitigando danos à sua reputação e imagem ${ }^{331}$ e conservando a estabilidade de sua atuação.

Exemplificativamente, a solução alternativa - pela celebração dos acordos - é benéfica aos investigados no que tange à divulgação de informações prevista no Formulário de Referência (artigo 24 da Instrução CVM n. 480, de 7 de dezembro de 2009). Pelos dados solicitados no preenchimento do Formulário mencionado, processos

\footnotetext{
${ }^{328} \mathrm{O}$ termo de compromisso garante "ainda a possibilidade de proteção ainda mais ágil do investidor prejudicado, ao se determinar que o mesmo seja indenizado de forma imediata". Parecer/CVM/PJU/005, de 10 de março de 1998.

329 " "[...] como se sabe, o exercício de atividades no âmbito do mercado de capitais depende primordialmente da credibilidade e da reputação que o profissional desfruta no mercado". CARVALHOSA e EIZIRIK (2002, p. 510).

330 “[...] sabe-se também, e disso têm claríssima noção quantos exercem suas atividades profissionais de alguma sorte em relação ao mesmo Mercado Financeiro e de Capitais, que este se baseia essencialmente na fidúcia, na confiança, na boa fama de que goze determinada instituição, empresa de capital aberto, agente autônomo, etc". MARREY NETO (2000, p. 95).

331 "A imagem de quem atua no mercado de capitais é, talvez, o seu bem mais precioso. Por imagem entendemos aquela que se forma junto aos investidores como: honestidade, honradez, seriedade, capacidade e eficiência. Se o simples indiciamento já pode abalá-la em alguns casos, a condenação, dependendo de seu grau, pode destruí-la”. AMENDOLARA (2008, p. 30).
} 
administrativos sancionadores que tenham como parte a companhia a que se refere o documento ou suas controladas devem ser indicados como um dos "fatores de risco" (item 4.3 do Formulário). A norma determina também, nos itens 12.8(b-i) e 12.8(b-ii) do Formulário, a obrigatoriedade de informar a existência de condenação judicial ou administrativa, perante a CVM, de qualquer membro da administração ou conselho fiscal, ocorrida nos últimos cinco anos. O normativo em exame, por outro lado, não exige qualquer informação sobre a celebração de termos de compromisso, equiparando-o ao caso de absolvição, no sentido de nenhum dos dois precisar ser referido - e unicamente em tal sentido ${ }^{332}$.

Mesmo tendo que assumir determinadas obrigações (inclusive o pagamento de valores que podem ser assemelhados ou superiores às multas a que estariam sujeitos), inexiste reconhecimento ou declaração de culpa pelo agente, ou de ilicitude das $\operatorname{condutas}^{333}$. Esta é, seguramente, uma vantagem dos termos, assegurada pela lei.

Outra vantagem é justamente evitar as decisões administrativas e as condenações que delas poderiam advir ${ }^{334}$. As condenações não são necessariamente previsíveis, e o julgamento de um caso pode acarretar, por exemplo, multa muitas vezes superior ao valor esperado ${ }^{335}$, além de inabilitação para o exercício de administração de companhias abertas, no caso de pessoas naturais. Outro exemplo de punição a qual estão sujeitos os infratores condenados é a suspensão ou cassação de autorização ou registro para atuar no mercado de valores mobiliários ${ }^{336}$.

Assim, com a propositura - seguida de adequada negociação e aceitação - de um acordo com a autoridade fiscalizadora, o administrado pode limitar os recursos ${ }^{337}$ a

\footnotetext{
332 O mesmo Formulário (item 12.11) demanda informações sobre acordos ou seguros que "prevejam o pagamento ou o reembolso de despesas suportadas pelos administradores, decorrentes da reparação de danos causados a terceiros ou ao emissor, de penalidades impostas por agentes estatais, ou de acordos com o objetivo de encerrar processos administrativos ou judiciais, em virtude do exercício de suas funções", que pode servir à identificação dos administradores que são beneficiários de apólices do tipo.

${ }_{333}$ Nos termos do apresentado no item 4.4 .

${ }^{334} \mathrm{O}$ mesmo se identifica no âmbito dos consent decrees norte-americanos. Sobre o tema, ISENBERGH e RUBIN (1939, p. 403) afirmam que "[...] the consent decree, offering as it does the only certain avenue of escape from possible fine or imprisonment, must tempt the hardiest business man".

335 Sendo tal o entendimento apresentado na "Política da SDE - Termo de Compromisso de Cessação de Prática em Cartel” (p. 2), divulgada em fevereiro de 2008, considerando também as vantagens percebidas pela administração pública, indicadas no item anterior: "Da mesma forma, há substanciais ganhos para o investigado em firmar um TCC. Tais benefícios configuram-se de diversas formas, como o potencial desconto no valor de eventual multa, que seria imposta ao final do processo administrativo".

${ }_{336}$ Conforme rol de penalidades indicadas no caput do artigo 11 da Lei 6.385/76.

337 "Tais acordos também trazem determinados benefícios aos acusados que são socialmente desejáveis, tais como a economia de custos com processo e litígio, bem como a redução da incerteza quanto à punição. A redução da incerteza é benéfica tanto para o acusado - pois limita seu grau de exposição a uma sanção cujo valor não sabe ao certo - bem como para a sociedade - pois gastos substanciais de recursos e persecuções prolongadas nem sempre resultam e punições satisfatórias". Voto do Conselheiro Paulo Furquim de
} 
serem empregados para extinguir a questão de forma definitiva. Com isso, minimiza a incerteza em relação aos gastos totais ${ }^{338}$ com o desenlace do caso, considerando a necessidade de assistência jurídica durante todo o processo administrativo (inclusive em grau de recurso) e, eventualmente, em discussão judicial posterior, além da condenação, que pode gerar efeitos de difícil quantificação, sobretudo nos casos de proibição de realização de operações, inabilitações ou suspensões.

Complementarmente, a inexistência de uma condenação administrativa impede que o compromitente seja, caso condenado em oportunidade posterior ${ }^{339}$, enquadrado como reincidente, pelo que ficaria sujeito à triplicação das penas de multa ou à aplicação de penas restritivas de direito, conforme previsto no artigo 11 , parágrafo $2^{\circ}$, da Lei $6.385 / 76$, conforme alterada ${ }^{340}$.

Com a suspensão e arquivamento dos procedimentos administrativos, provocados pela celebração dos termos, evitam-se os distúrbios e preocupações acarretados pela investigação ou pela participação do agente, na condição de réu, no processo sancionador $^{341}$, cessando também as despesas ${ }^{342}$ prolongadas e eventualmente imprevisíveis acarretadas pela participação em tais procedimentos, inclusive com advogados, custas judiciais para eventual recurso após o julgamento administrativo, relações públicas para promoção e resgate da integridade da imagem do agente

Azevedo, relator do Requerimento 8700.004992/2007-43, no contexto do Processo Administrativo 08012.011142/2006-79, conduzido pelo CADE, p. 9.

338 "Tais acordos também trazem determinados benefícios aos acusados que são socialmente desejáveis, tais como a economia de custos com processos e litígio, bem como a redução da incerteza quanto à punição. [...] [o valor a ser compromissado] limita seu grau de exposição a uma sanção cujo valor não sabe ao certo". Voto do Conselheiro Paulo Furquim de Azevedo, relator do Requerimento 8700.004992/2007-43, no contexto do Processo Administrativo 08012.011142/2006-79, conduzido pelo Conselho Administrativo de Defesa Econômica - CADE (pp. 9-10).

${ }^{339}$ Sobre o tema, vale o registro do histórico de Diretor de Relações com Investidores de companhia aberta de economia mista, controlada pela União, que celebrou três termos de compromissos (Processos administrativos RJ 2007/13889, RJ 2009/3049 e RJ 2009/6713), todos em razão de inobservância do dever de divulgação imediata de fato relevante, pelos quais foram recolhidos pagamentos totais no montante de $\mathrm{R} \$ 1.500 .000,00$ (um milhão e quinhentos mil reais). Ainda que os valores tenham sido incrementados progressivamente (respectivamente, $\mathrm{R} \$ 100.000,00$ para o primeiro, aprovado em setembro de 2008; $\mathrm{R} \$ 400.000,00$ para o segundo, aprovado em dezembro de 2009; e $\mathrm{R} \$ 1.000 .000,00$ para o terceiro, aprovado em maio de 2010), é possível admitir argumentos contrários à sucessiva celebração de acordos com os mesmos administrados, em razão de condutas idênticas. Parece, nesses casos, não estar sendo produzido o efeito dissuasório pretendido.

340 "Em situações como essa, o indiciado ou acusado interessa-se pelo estancamento do procedimento administrativo, tendo em vista, por exemplo, manter-se na condição de primário quanto a condenações determinadas pela CVM, a fim de não correr o risco de, mais, tarde, ser condenado na qualidade de reincidente, caso em que virá a sofrer uma penalidade mais grave”. VERÇOSA (1998, p. 203).

341 “O infrator poderá se ver rapidamente 'livre' dos ônus da investigação administrativa e de eventual aplicação de penalidades”. DUBEUX (2006 p. 100).

342 “Os 'acusados', por sua vez, preferem evitar as despesas, publicidade negativa e perturbações em seus negócios que um julgamento poderia acarretar, assim como as consequências nefastas que poderiam decorrer de uma eventual condenação”. EIZIRIK (1998, Reforma..., p. 264). 
eventualmente condenado perante seus pares, o mercado e a comunidade em geral, entre outros.

A avaliação inicial, pelo administrado, sobre a apresentação ou não de proposta, e sobre os termos do acordo a ser apresentado à administração, deve considerar (i) a densidade do conjunto probatório existente, para avaliação da probabilidade de condenação; (ii) a interpretação das tendências de julgamentos ${ }^{343}$ e acordos administrativos celebrados, para mensuração da pena a ser aplicada, caso exista condenação; (iii) o fator temporal, essencial para a decisão, pois o pagamento de determinada quantia em certo momento não tem o mesmo significado econômico do que o pagamento da mesma quantia algum tempo depois ${ }^{344}$; (iv) os demais gastos, certos e hipotéticos (no caso dos últimos, também a probabilidade de virem a se concretizar), a serem despendidos caso o procedimento administrativo seja conduzido até o final, e que pode ser economizado com a celebração de acordo.

Eis os elementos nucleares para avaliação, pelos agentes, a respeito do interesse em oferecer à administração uma proposta de termo de compromisso (e sob quais condições) ou, alternativamente, antevendo ser-lhe mais vantajosa, optar pela condução regular do inquérito administrativo, mesmo que transformado em processo administrativo $^{345}$. Nesta última hipótese, o agente tenderá a decidir pela não proposição de acordo, ou de acordo muito aquém em relação a aquele que estaria disposto a oferecer ${ }^{346}$.

\footnotetext{
343 Inclusive a qualidade das decisões e dos procedimentos decisórios, os quais podem influenciar na possibilidade de reversão do julgamento perante o Poder Judiciário: maior a chance de um administrado propor termo satisfatório ao interesse público quanto melhor forem as decisões dos casos, e menor a reversibilidade judicial. No mesmo sentido, caso o administrado constate que a Comissão, em julgamento administrativo, seguramente absolve os agentes inocentes das acusações, a comparação a ser feita por agente seguro de sua inocência será apenas entre os gastos a serem despendidos com a condução do processo administrativo e o valor a ser proposto (ou entendido como adequado) pela CVM.

${ }^{344}$ É possível que o fator temporal tenha mais relevância para alguns tipos de administrados do que para outros: para um banco, por exemplo, cuja capacidade de aplicação e de obtenção de retorno de investimento é potencializada em relação a uma pessoa natural que não seja titular de um grande montante para investimentos, o diferimento entre o pagamento em uma data ou em outra, muito posterior, pode ser fator decisivo para a apresentação ou não de proposta de acordo, ou para aceitação ou rejeição de contraproposta apresentada pela Comissão.

${ }^{345}$ Elementos assemelhados são indicados no estrangeiro como motivadores da decisão: BAKER, N. A. et. al. (2007, p. 258), especificamente no trecho da lavra de OCHS e PHILLIPS, indicam que "the decision to settle or to litigate requires careful evaluation of a number of considerations. Before entering into settlement negotiations, there should be a realistic appraisal of the merits of the Commission's charges and the ability of the proposed defendants to withstand potentially protracted litigation. In addition, the potential sanctions and collateral consequences of litigation should be considered".

346 "Como usualmente assumido na teoria econômica, é razoável admitir que as representadas escolham a alternativa (e.g. assinatura de um TCC vis-à-vis a continuidade do processo) que lhes proporcione maior retorno, levando-se em conta a multa esperada, contribuição pecuniária ao fundo de direitos difusos, obrigações de fazer, custos diversos do carregamento do processo e seu grau de aversão ao risco". Voto do Conselheiro Paulo Furquim de Azevedo, relator do Requerimento 8700.004992/2007-43, no contexto do
} 
Em síntese, o administrado deve analisar se estima serem mais significativos os custos "relacionados ao curso do processo administrativo e privadamente incorridos [...]: punição dissuasória, reunindo a sanção administrativa e eventual alteração de probabilidade de condenação penal ou em ações civis de indenização, e os demais custos de carregamento do processo", ou se, em sua projeção, os "custos decorrentes de contribuição pecuniária e obrigações de fazer" seriam menos elevados ${ }^{347}$. Certamente o proponente do termo de compromisso, agente racional, apenas concorda com eventual contraproposta da Comissão, usualmente apresentada pelo Comitê de Termo de Compromisso, caso entenda que sua situação com a celebração de acordo será melhor do que aquela configurada pelo prosseguimento do processo administrativo sancionador ${ }^{348}$.

A título de conclusão do item, é possível apontar como vantagens para o administrado, advindas da celebração de termos de compromisso, a economia de tempo, trabalho e de outros recursos despendidos em menor quantidade na celebração do termo, em comparação aos totais gastos relativos ao processo administrativo. Os agentes podem evitar a acusação administrativa e potenciais desfechos judiciais, mantendo o foco em sua atividade-fim $^{349}$. Ainda, podem ser evitadas as consequências prejudiciais à imagem e reputação que usualmente decorrem de condenações; além de produzida a segurança de uma não condenação ${ }^{350}$, com as benesses de prevenção à reincidência ${ }^{351}$.

Processo Administrativo 08012.011142/2006-79, conduzido pelo Conselho Administrativo de Defesa Econômica - CADE, p. 9.

${ }^{347}$ Conforme pensamento desenvolvido no Voto do Conselheiro Paulo Furquim de Azevedo, relator do Requerimento 8700.004992/2007-43, no contexto do Processo Administrativo 08012.011142/2006-79, conduzido pelo CADE. pp. 14-21. Descartando-se os aspectos aplicáveis exclusivamente ao contexto concorrencial, parte não desprezível da lógica pode ser aproveitada pelo investigado pela CVM, para orientar sua decisão de propor acordo com a administratação.

348 “[...] condições alternativas podem ser negociadas com o próprio interessado, o que liberta a solução da questão do formalismo processual que apenas resultaria, ao final, na imposição de uma penalidade enquanto o que realmente se pretende é a reparação dos danos sofridos pelos investidores e pela sociedade de um modo geral. E o acordo ainda oferece vantagens para a CVM, que pode destinar os recursos materiais e humanos que desprenderia na instauração e conclusão do processo para outras atividades. Portanto, a celebração de termo de compromisso não apenas possibilita o efetivo ressarcimento dos prejuízos de terceiros sem ônus para os prejudicados, já que não há a necessidade de serem tomadas medidas judiciais; como também garante a plena efetividade do princípio da moralidade administrativa, visto que libera a CVM para dedicar-se a demais atividades também do interesse público, e da eficiência". Norma Parente, no Voto apresentado no Processo CVM 2003/12433 (alteração da D. CVM 390/01 previamente à audiência pública de 2005. Tal voto, vale o registro, traz breves impressões da autora sobre ferramentas assemelhadas aos termos de compromisso adotadas em diversos países, incluindo menos estudados como Singapura, Nova Zelândia, Canadá, Polônia e Austrália).

349 "Ademais, o encerramento de investigações pendentes proporciona à empresa a oportunidade de direcionar esforços antes destinados ao processo para outras áreas, utilizando seus recursos de forma mais eficiente". ("Política da SDE - Termo de Compromisso de Cessação de Prática em Cartel", divulgada em fevereiro de 2008, p. 2).

350 “"...] em última instância, a suspensão do processo representa a possibilidade de que virtuais infratores se eximam de penalidades iminentes, privilegiando-se, por outro lado, uma solução mais rápida, que elimine os efeitos negativos das práticas não condizentes com com as normas vigentes, proporcionando ainda a 
Outra potencial vantagem é a de transmitir ao regulador, com quem os agentes usualmente têm um contato relativamente frequente e próximo, o interesse em resolver qualquer questionamento comportamental da maneira mais breve e satisfatória possível, mediante apresentação de uma proposta que satisfaça os anseios da administração e, em última análise, do mercado ${ }^{352}$.

Cabe apenas lembrar que proporcionar vantagens a ambas as partes (administração e administrado) é pressuposto do acordo administrativo, cuja natureza decorre de concessões mútuas. Um acordo que seja muito mais benéfico a uma das partes em relação à outra, além de deturpar sua natureza e propósitos, tende a não ser aceito.

possibilidade de uma proteção ainda mais ágil do investidor prejudicado". Parecer/CVM/PJU/005, de 10 de março de 1998.

351 GRAU e FORGIONI (2005, p. 234) tratam da lógica dos termos de compromisso no âmbito concorrencial, cuja racionalidade pode ser aproveitada, em grande parte, ao contexto do mercado de valores mobiliários.

${ }^{352}$ Nesse sentido, benefício identificado na "Política da SDE - Termo de Compromisso de Cessação de Prática em Cartel", divulgada em fevereiro de 2008, p. 2: "Por fim, as empresas e pessoas físicas envolvidas em uma investigação de cartel podem desejar finalizar suas pendências de forma rápida e, assim, traçar uma linha clara entre suas condutas passadas e futuras". 


\section{RESTRIÇÕES À REALIZAÇÃO DO ACORDO}

A celebração de termos de compromisso é possível em todos os processos administrativos instaurados para apuração a infrações às regras do mercado de valores mobiliários, sob a alçada da CVM. Existe, contudo, uma hipótese de processo conduzido pela CVM por delegação em que não são possíveis os acordos, e também um projeto de lei que visa limitar a aplicação dos acordos substitutivos em determinadas circunstâncias.

Ambos os temas serão tratados nos itens do presente tópico, por dizerem respeito a restrições à celebração dos termos, seja vigente ou potencial.

\subsection{Ilícitos relacionados à "lavagem" de bens, direitos ou valores}

Pelo regramento do mercado de valores mobiliários brasileiro, administrados investigados pela Comissão de Valores Mobiliários podem submeter proposta de termo de compromisso objetivando a suspensão e arquivamento de procedimentos administrativos sancionadores, a qual é avaliada por essa autarquia seguindo critérios de conveniência e oportunidade. Em adição aos requisitos essenciais (cessação da conduta e correção das supostas irregularidades ${ }^{353}$ ), sem os quais não pode ser aceita qualquer proposta, há outra limitação à discricionariedade da CVM, na aceitação ou recusa das propostas. Trata-se da vedação plena aos acordos em procedimentos instaurados para apuração de condutas relacionadas à infração de regras para prevenção à ocultação ou dissimulação ("lavagem”) de bens, direitos e valores oriundos, diretamente ou não, de infrações ${ }^{354}$, conforme estabelecidas na Lei n. 9.613, de 3 de março de 1998 (“Lei 9.613/98”) e na Instrução CVM n. 301, de 16 de abril de 1999 (I. CVM 301/99) ${ }^{355}$.

As intimações encaminhadas pela Comissão aos administrados para apresentação de defesa administrativa ou acompanhamento de procedimentos costumam informar sobre a possibilidade de oferecimento de proposta para celebração de termo de compromisso, trazendo expressa a exceção com relação à apuração das infrações relacionadas à lavagem de dinheiro, em que é vedada a aceitação de acordos, conforme definido no artigo $1^{\circ}$, parágrafo $1^{\circ}$, da D. CVM 390/01, que trata de questões procedimentais relacionadas aos termos de compromisso.

\footnotetext{
${ }^{353}$ Referidas no item 4.3 .

${ }^{354}$ Conceito do artigo $1^{\circ}$ da Lei 9.613/98, conforme alterada.

355 “[...] cumpre ressaltar que não é admitida a celebração do termo de compromisso em processos relativos a infrações das normas da Lei n. 9.613/98 e da Instrução CVM n. 301/99. Isso especialmente, porque a legislação pertinente à lavagem de dinheiro contempla um núcleo de direito substantivo e prevê um rito procedimental próprio que não remetem à possibilidade de celebração de ajustes daquela espécie." SANTOS et. al. (2012, p. 222).
} 
O resultado da manifestação de interesse na apresentação de proposta, nos casos em que há proibição, é a resposta ao administrado no sentido de que "não há possibilidade de celebração de Termo de Compromisso" em tais situações, esclarecendo-se que "o poder de regulação exercido pela CVM, [...] [em tais casos] não se dá apenas por força da Lei $n^{\circ} 6.385 / 76$, mas também por força da Lei $n^{\circ} 9.613 / 98$ "356.

Digno de menção é o caso ${ }^{357}$ ocorrido pouco antes da publicação da D. CVM 390/01, responsável por aclarar a impossibilidade de celebração de acordos no campo de apuração de infrações obstaculizantes da prevenção e repressão à lavagem de dinheiro.

Foi registrado no relatório que os acusados não se conformaram "com a não permissão para a celebração de termo de compromisso apresentado antes da edição da Deliberação CVM no 390/2001" e que a Superintendência de Relações com o Mercado e Intermediários da Comissão manifestou entendimento no sentido de que "o termo de compromisso só é cabível em processo decorrente da Lei $n^{\circ}$ 6.385/76 e não se aplica aos processos decorrentes da Lei no 9.613/98,358. Em seu voto, a então Diretora Norma Parente esclareceu que a Superintendência estava correta, mas ajustou o fundamento da negativa à possibilidade de acordo, para explicar que os termos de compromisso podem ser celebrados apenas nos procedimentos instaurados para apurar infrações previstas na Lei 6.385/76, inexistindo previsão, na Lei 9.613/98, para a celebração de tais acordos ${ }^{359}$.

Considerando os precedentes identificados nos Processos Administrativos Sancionadores CVM n. SP 2003/0152, SP 2000/0133 e SP 2000/0129 ${ }^{360}$, parece ser entendimento da Comissão de Valores Mobiliários de que a apuração administrativa de condutas cuja ilicitude decorre da Lei 9.613/98, por si só, exclui a possibilidade de

\footnotetext{
356 Voto do Relator Sergio Weguelin no julgamento do Processo Administrativo Sancionador CVM n. SP 2003/0152, em 29 de março de 2006.

${ }^{357}$ Processo Administrativo Sancionador CVM n. SP 2000/0133, cujo julgamento pelo Colegiado e voto da Relatora Norma Parente datam, ambos, de 12 de novembro de 2001.

${ }^{358}$ Relatório da Diretora Norma Parente no Processo Administrativo Sancionador CVM n. SP 2000/0133.

359 "Com relação ao questionamento sobre o termo de compromisso, cabe reconhecer que, por se tratar de matéria nova, houve, de fato, um equívoco na informação contida no ofício da SMI. Na verdade, a celebração do termo só é admissível em processos envolvendo ilícitos da Lei $n^{\circ} 6.385 / 76$, não havendo previsão para os regidos pela Lei ${ }^{\circ}$ 9.613/98. Portanto, sua inaplicabilidade ao presente caso não decorre de entendimento ou da Deliberação CVM No 390/2001".

${ }^{360}$ Relatado pelo Diretor Wladimir Castelo Branco de Castro, em 4 de setembro de 2001. No relatório lê-se que os acusados insistiram "na celebração de Termo de Compromisso, alegando que estariam sendo prejudicados, pelo fato de uma norma retroagir, que seria a Deliberação CVM n ${ }^{\circ} 390$, para obstar o seu direito, de modo inconstitucional", o que foi rebatido pelo Diretor Relator ao afirmar que "de modo algum se pode aceitar que a Deliberação 390 tenha promovido alterações de Direito. Tal ato, por parte da CVM, veio apenas esclarecer uma situação que preexistia, [...] vem apenas orientar o mercado para algo que lhe antecede. Na verdade, o diploma legal a obstar a pretensão de defesa é a exegese da Lei n ${ }^{\circ}$ 9613/98, preexistente aos fatos". Por fim, o Relator contextualiza a vedação, em relação à discricionariedade da CVM: “Às vezes o termo proposto não é satisfatório, ou conveniente, e a decisão de conceder, ou não, variará, conforme as circunstâncias. No caso que ora se examina, não pode ser feito, por impeditivos legais”.
} 
celebração de termos de compromisso, e o parágrafo $1^{\circ}$ do artigo $1^{\circ}$ da D. CVM 390/01 não inovou (até porque essa Deliberação poderia ser questionada, caso fizesse), mas apenas evidenciou tal impossibilidade, já pré-existente.

Dessa forma, considerando inexistir autorização expressa na Lei 9.613/98 ou no Decreto n. 2.799, de 8 de outubro de 1998 (regulamentador da lei citada) para a celebração de acordos para a suspensão e arquivamento dos ilícitos ali disciplinados, a inviabilidade dos acordos em procedimentos fundamentados na I. CVM 301/99 parece ser mais uma questão legislativa ${ }^{361}$ do que uma opção de política regulatória, como uma leitura isolada do artigo $1^{\circ}$, parágrafo $1^{\circ}$, da D. CVM 390/01 sugere, verbis: “[...] §1 $1^{\text {o }}$ Não será admitida a celebração do termo de compromisso em processos relativos a infrações das normas da Lei n. 9.613, de 3 de março de 1998, e da Instrução CVM n. 301, de 17 de abril de 1999".

Interessante registrar o ocorrido no Processo Administrativo Sancionador CVM n. 01/2006, instaurado para apurar potenciais infrações em operações realizadas em bolsa de valores e de mercadorias e futuros, por pessoas naturais e jurídicas. Durante a instrução, agentes de fiscalização da CVM encontraram indícios de descumprimento de regras relacionadas à prevenção à lavagem (constantes da Lei 9.613/98 e I. CVM 301/99), o que inviabilizaria qualquer acordo caso fossem as infrações originalmente investigadas e as novas tratadas em conjunto, em um mesmo procedimento, por conta da vedação ora referida. A Comissão de Inquérito, porém, decidiu tratar das condutas relacionadas à possível lavagem de dinheiro em processo administrativo em apartado ao original, instaurado especificamente para tais fins, com o que possibilitou a manutenção da viabilidade da celebração de termo de compromisso no caso, o que foi recomendado pelo Comitê de Termo de Compromisso, em 27 de junho de $2006^{362}$.

\footnotetext{
${ }^{361}$ Remetendo tal situação à questão do interesse da CVM de promover acordos antes da vigência da Lei 9.457/97, impedido por falta de previsão legal autorizativa, referido no item 2.1 supra.

${ }^{362}$ A título informativo, o Colegiado rejeitou a proposta, entendendo ser mais interessante à administração o julgamento do caso "para fins de bem orientar as práticas do mercado em operações da espécie". Também justificou tal decisão o fato de que apenas parte dos acusados havia proposto o acordo substitutivo, o qual "não caracterizaria qualquer ganho para a Administração, em termos de celeridade e economia processual", porque apenas parte dos acusados apresentou proposta, e a continuação da instrução e julgamento seriam necessários com ou sem a aceitação do acordo (conforme ata da reunião do Colegiado de 21 de agosto de 2007).
} 


\subsection{Projeto de Lei $1.851 / 2011$}

Ainda sobre o tema de vedação à celebração de termos de compromissos em casos específicos, em 13 de julho de 2011 foi apresentado na Câmara dos Deputados o Projeto de Lei 1.851 (“PL 1.851"), sugerindo a proibição de celebração de termos de compromisso entre particulares e a CVM em procedimentos administrativos nos quais se apurem condutas relacionadas aos crimes de manipulação de mercado e uso de informação privilegiada (previstos nos artigos 27-C e 27-D da Lei 6.385/76, respectivamente) ${ }^{363}$.

O Deputado autor do PL 1.851, como pode ser interpretado a partir da Justificação apresentada ${ }^{364}$, reconhece os "benefícios advindos da maior celeridade na apuração e julgamento de delitos pelo ente regulador" em virtude dos acordos, mas defende que a ferramenta tem se revelado contrária ao interesse público nos casos de uso indevido de informação privilegiada, os quais "minam a confiança do mercado de capitais, configurando um verdadeiro atentado contra a economia popular".

Segue a argumentação defendendo que “[...] por se tratar de uma infração considerada grave pela legislação, já tipificada como ilícito penal (art. 27-D da lei $^{365}$ 6385/76), nada poderia justificar a interrupção do processo administrativo de investigação". E acrescenta que a conduta de manipulação de mercado, prevista no artigo 27-C da Lei 6.385/76 "é prática nefasta e afronta a credibilidade das operações no mercado de capitais".

Conclui a confusa Justificação afirmando que os crimes mencionados não são “de menor potencial ofensivo", nos termos da Lei n. 9.099, de 26 de setembro de 1995, e que, por isso, tem "convicção de que a proibição de uso de termos de compromisso por parte da Comissão de Valores Mobiliários é inquestionável para que se possa defender o interesse público".

Não parece incontestável a ideia de que o compromisso celebrado em casos envolvendo os ilícitos citados importaria, na totalidade dos casos, em prejuízo ao mercado de valores mobiliários, ao supostamente premiar as condutas ilícitas, que no entender da Justificação do PL 1.851 não mereceriam o oferecimento do termo de compromisso, mas, ao contrário, deveriam ser apuradas exaustivamente.

\footnotetext{
${ }^{363}$ Pela inclusão de um parágrafo 13 ao artigo 11 da Lei 6.385/76, assim projetado: "O compromisso a que se refere o $\S 5^{\circ}$ deste artigo não poderá ser firmado nos casos que envolvam procedimento administrativo instaurado para a apuração de infrações relativas aos crimes previstos nos artigos 27-C e 27-D desta Lei”. 364 Disponível em $<$ http://www.camara.gov.br/proposicoesWeb/prop mostrarintegra?codteor=899991\&filename=TramitacaoPL+1851/2011>, acesso em jul2012.

${ }^{365}$ Com letra minúscula no documento apresentado pelo próprio deputado.
} 
A "questão de princípio"366 suscitada pelo autor do PL 1.851 encerra duas inconsistências principais: ignorância da separação das esferas de responsabilização ${ }^{367}$ e tentativa de sufocar a discricionariedade da Comissão, ao tentar vedar, a priori, a utilização dos termos de compromisso, os quais podem muitas vezes ser mais benéficos ao interesse público do que a própria continuidade da apuração de infrações administrativas ${ }^{368}$.

Quanto ao primeiro ponto - ao qual se dedicou um tópico próprio (a incluir também a esfera da responsabilidade civil) -, cumpre referir que o tratamento dado pela Comissão de Valores Mobiliários às infrações administrativas de insider trading ou manipulação do mercado não prejudicam o enquadramento criminal da mesma conduta, pelo mesmo agente, a ser apurada pelos órgãos competentes: Polícia, Ministério Público e Poder Judiciário.

Assim sendo, a celebração de termos de compromisso com a CVM não vincula o Ministério Público, que pode decidir por também celebrar um acordo (eventualmente em conjunto com a Comissão, ou separadamente ${ }^{369}$ ), ou por seguir com as medidas cabíveis. A

\footnotetext{
366 “O termo é muito generoso com os acusados. Ainda que haja ressarcimento, o acordo minimiza o delito. Trata-se de uma questão de princípio. O ilícito é grave e não permite fazer comutação da pena. Negociações de insiders e manobras fraudulentas são práticas nefastas e que afrontam a credibilidade das operações no mercado de capitais", afirmou o autor do PL 1.851, Deputado Chico Alencar, à época da sua apresentação, conforme declaração ao jornal Valor Econômico, extraída da matéria "Projeto veta acordo para "insiders", de autoria de Denise Carvalho, veiculada em 25 de agosto de 2011, pp. D1 e D9.

${ }^{367}$ Tratada no item 13.1.

${ }^{368}$ Conforme referido no item 6.1.

${ }^{369}$ É possível citar como exemplo o caso das acusações de utilização de informação privilegiada contra o mesmo cidadão, apurada em âmbito administrativo pelo Processo Administrativo Sancionador CVM n. SP 2007/0119 e na ação penal autuada sob o n. 0005123-26.2009.403.6181, distribuída à 6 ${ }^{a}$ Vara Especializada em Crimes Contra o Sistema Financeiro Nacional e Lavagem de Valores, na Seção Judiciária de São Paulo da Justiça Federal (em que o acusado no processo administrativo era um dos três réus). No âmbito administrativo foi celebrado termo de compromisso, condicionado ao pagamento de determinada quantia à CVM, entendida como "obrigação de caráter preventivo, por caracterizar compromisso dado como bastante para inibir a prática de condutas semelhantes pelo próprio proponente e por terceiros que se encontrem em situação similar à daquele" (conforme ata da reunião da Diretoria Colegiada da CVM de 4 de março de 2008, que aprovou o acordo). Já na persecução penal, o mesmo cidadão, "Em audiência realizada no dia 20 de abril de 2010, [omitido] aceitou a proposta de suspensão condicional do processo, razão pela qual o feito foi desmembrado em relação a ele" (página 5 da sentença proferida em 16 de fevereiro de 2011, disponível em

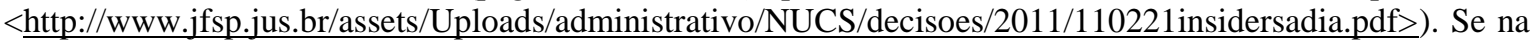
ação civil pública é possível celebrar termo de ajustamento de conduta e no processo administrativo sancionador é possível firmar termo de compromisso, na esfera penal não é possível um acordo, após o início da ação penal, por força da obrigatoriedade da ação penal: "O Ministério Público Federal, nos termos da Lei da Ação Civil Pública, realiza Termo de Ajustamento de Conduta e a CVM também, dentro de sua regulamentação. Mas, no âmbito do direito penal [...] não existe, por força do princípio da obrigatoriedade da ação penal pública, a possibilidade de ajuste. Uma vez promovida a denúncia, uma vez promovida a ação penal, o Poder Judiciário vai ter que se manifestar sobre aquilo que, de fato, foi veiculado pelo Ministério Público. Que existe, evidentemente, são alguns instrumentos de diversificação penal, como a suspensão condicional do processo, desde que o fato, a conduta se enquadre nos termos do Art. 89 da Lei 9.099". Declaração de de Grandis, p. 23 dos Cadernos Direito GV, Seminário 38, v. 7, n. 6, nov. 2010. O desfecho de ambos os casos, ainda que não tenham sido por decisões condenatórias, foram independentes e por argumentos diversos.
} 
situação oposta também é possível, mediante acordo judicial para extinção de ação penal, desde que exista decisão condenatória no contexto sancionador.

Concluindo os apontamentos à primeira inconsistência, é possível entender que a celebração de acordos entre a autoridade administrativa e o investigado por insider trading ou manipulação do mercado, diferentemente do que o autor do PL 1.851 entende, não deve ser vedada em razão de serem "graves" os ilícitos criminais em que as mesmas condutas podem ser enquadradas, uma vez que inexiste restrição, na disciplina administrativa, à celebração de acordos por infrações consideradas graves.

O segundo argumento visa rebater o pensamento de que "nada poderia justificar a interrupção do processo administrativo de investigação" nos casos referidos, nos quais o encerramento de processos administrativos por acordos "tem se revelado contrário ao interesse público".

Não é porque - no entendimento pessoal do integrante do Poder Legislativo os acordos aceitos pela Comissão em casos de apuração de manipulação do mercado e negociação por detentores de informação privilegiada tem se mostrado insatisfatórios para promoção do interesse público por ela tutelados ${ }^{370}$ que se afigura correta a alternativa de extinguir a possibilidade de a CVM celebrar termos de compromisso em tais hipóteses, sob o argumento de que há, apenas nesses casos, uma flexibilização forçada e indevida do dever de investigação que cabe a essa autarquia, e que são infrações administrativas mais lesivas ao mercado de valores mobiliários, em comparação a outras.

A discricionariedade da CVM, limitada pelas balizas legais apresentadas anteriormente, evidencia-se como a melhor maneira de orientar as análises nos casos em que é possível "justificar a interrupção do processo administrativo de investigação". Por esse sistema a Comissão está apta para avaliar quando prosseguir com uma investigação for menos interessante do que a aceitação de proposta de termo apresentada, inclusive nos

\footnotetext{
${ }^{370}$ O que é discutível, considerando, exemplificativamente, o teor dos termos celebrados nos Processos Administrativos Sancionadores n. RJ 10/08, SP 2007/119, 19/2006, RJ2008/10421, todos tratando das situações suscitadas pelo parlamentar, nos quais não é possível identificar inoportunidade ou inconveniência da CVM na aceitação das propostas. Inclusive no último dos casos citados, o registro da ata da reunião da Diretoria Colegiada de 18 de agosto de 2009 aponta que "O Diretor Eli Loria deixou consignada sua recomendação ao Comitê de Termo de Compromisso para que avalie a possibilidade de basear o valor a ser fixado como pagamento à CVM em percentagem das operações irregulares, ao negociar Termos de Compromisso com imputação de eventual descumprimento ao disposto no caput e $\S 4^{\circ}$ do art. 13 da Instrução 358/02", aproximando os resultados dos acordos à dosimetria de multa determinada na regra do artigo 11, parágrafo $1^{\circ}$, III da Lei 6.385/76. Também abundam exemplos de propostas de acordo para extinção de processos administrativos para apuração de conduta de insider traders e manipulação do mercado recusados, por não atingirem patamares entendidos pela Comissão como suficientes à satisfação do efeito dissuasório pretendido com os termos de compromisso (exemplos de propostas recusadas podem ser encontrados no Inquérito Administrativo CVM 11/2008 e nos Processos Administrativos Sancionadores 06/2003, 06/2007, 01/2010 e 19/2009).
} 
casos de transação por insider ou manipulação do mercado, em que a obtenção de provas a respeito da materialidade e da intenção do agente nem sempre é fácil.

Para defender o interesse público, como pretendido pelo Deputado, parece ser mais adequada a manutenção do formato atual, no qual a CVM pode decidir, de acordo com as peculiaridades de cada caso, se mais proveitoso à tutela do mercado de valores mobiliários a aceitação da proposta de termo apresentada ou o julgamento do caso, a depender da infração que esteja por ser apurada, independentemente de uma regra determinando a impossibilidade de acordo.

Foi determinado, por despacho datado de 8 de agosto de 2011, publicado no Diário da Câmara dos Deputados no dia seguinte (página 39.954), que o PL 1.851 ora referido fosse apensado ao Projeto de Lei n. 961, de 3 de maio de 2007, pendente (desde abril de 2011) de relatório, pela Comissão de Finanças e Tributação da Câmara.

\subsection{Outros casos pontuais de vedação legal à celebração de termo de compromisso}

A experiência de vedar a adoção de termos de compromisso nos procedimentos em que há apuração de determinadas condutas, tal como proposto no PL 1.851 examinado acima, foi vivida anteriormente pelo direito concorrencial. Em 2000, seis anos após a lei que introduziu a ferramenta de enforcement no contexto do Sistema Brasileiro de Defesa da Concorrência, foi instituída restrição à celebração de termos quando da apuração de situações de cartel (definição de condutas, preços, condições, mercados fornecedores ou consumidores em conjunto com concorrentes) e combinação de preços em concorrência pública ou administrativa ${ }^{371}$.

O argumento para a exclusão legal da possibilidade de composição administrativa em tais circunstâncias era de que "os perpetradores dos ilícitos de cartel, cujo grau de lesividade à ordem econômica é máximo, não podem ser premiados com as vantagens ou concessões decorrentes de acordo"372. Por outro lado, ainda que fosse unânime a ideia de que tais ofensas, por serem inegavelmente graves, deveriam ser objeto de punição severa, e eventualmente não devessem seus agentes ter qualquer proposta de termo de compromisso de cessação aceita, o contraponto era importante: a prova de tais infrações é de complexa obtenção, o que faz com que as apurações e investigações sejam

371 Artigo $1^{\circ}$ da Lei 10.149 , de 21 de dezembro de 2000, que alterou, entre outros, o artigo 53 da Lei 8.884/94. Diversos trabalhos tratam dessa restrição e de sua evolução, entre os quais artigo recente de DANTAS (2011).

${ }^{372}$ CUEVA (2007, p. 293). 
naturalmente mais prolongadas, "em detrimento do interesse público maior de fazer cessar a infração, e, tanto quanto possível, recompor o dano por ela causado",373.

Posteriormente, já em $2007^{374}$, houve nova alteração na disciplina legal dos termos de compromisso de cessação celebrados entre o CADE e os representados. Entre outros ajustes, foi excluída a restrição expressa à possibilidade de celebração de termos em quaisquer situações predeterminadas. Assim, voltou a ser plena a discricionariedade dessa autarquia para decidir em que casos podem ou não serem firmados os acordos.

Outra limitação que existiu no contexto da proteção à ordem econômica, ainda que por certo tempo, foi a vedação à celebração de compromissos de cessação entre a Secretaria de Direito Econômico do Ministério da Justiça (então integrante do SBDC) e particulares, nas hipóteses em que existissem provas suficientes para a condenação do proponente do termo. Era o que estabelecia, em seu parágrafo único, o artigo 40 da Portaria 849, de 22 de setembro de 2000, do Ministério da Justiça ${ }^{375}$, revogada expressamente por outra portaria, de 2006, que não repetiu tal restrição, da qual não há qualquer registro de reprodução ${ }^{376}$.

\footnotetext{
${ }^{373}$ CUEVA (2007, p. 293). Adicionalmente, o ex-Conselheiro do CADE e atual ministro do Superior Tribunal de Justiça informa que "os EUA e a União Européia, por exemplo, não somente não excluem quaisquer ilícitos do campo de aplicação dos compromissos de cessação como de fato solucionam a maior parte das práticas de cartel mediante a utilização de instrumentos de negociação".

${ }_{374}$ Artigo 16 da Lei 11.482/07, que promoveu nova alteração no artigo 53 da Lei 8.884/94.

375 "Parágrafo único. O compromisso de cessação não poderá ser celebrado se a SDE dispuser de provas suficientes para assegurar a condenação do representado, relativamente à prática sob investigação, no momento de assinatura do respectivo instrumento."

${ }^{376}$ Conforme relata CUEVA (2006, p. 295).
} 


\section{EFEITOS SOBRE A PRESCRIÇÃO}

A Lei 9.457/97 tratou também de inserir na Lei 6.385/76 regra a respeito da prescrição no mercado de valores mobiliários, com a criação do artigo 33, além de estipular também causas pelas quais há interrupção da prescrição.

Atendendo a um pressuposto lógico - não faria sentido (e poderia desencaminhar a nova ferramenta) a fluência de prazos prescricionais enquanto vigente termo de compromisso firmado entre a CVM e administrados -, estabeleceu o artigo 33, parágrafo $2^{\circ}$, da Lei 6.385/76, instituído na reforma operada pela Lei 9.457/97, que "a prescrição interrompe-se: [...] IV - Pela assinatura do termo de compromisso, como previsto no $\S 5^{\circ}$ do artigo 11 desta Lei”.

Em 30 de junho 1998, porém, foi editada a Medida Provisória n. 1.708, estabelecendo regras gerais sobre prazo de prescrição para o exercício de ação punitiva pela Administração Pública Federal, direta e indireta, pela qual o artigo 33 da Lei 6.385/76 seria revogado expressamente, com a criação de um artigo ordenando a suspensão ${ }^{377}$ da prescrição durante a vigência de termo de compromisso celebrado com a Comissão.

Após dezessete reedições, a Medida Provisória foi convertida na Lei n. 9.873, de 23 de novembro de 1999 (“Lei 9.873/99”), cujo artigo 3º, II, igualmente determina, na vigência do termo de compromisso, a suspensão da prescrição ${ }^{378}$. Considerando tal redação, hoje a vigência de termo de compromisso configura causa de suspensão da prescrição. Caso o termo não seja cumprido, a contagem do prazo prescricional deverá ser retomada do ponto em que foi suspensa. Na hipótese de cumprimento, o procedimento administrativo é arquivado.

Destaque-se não ser outro o efeito dos acordos administrativos sobre a prescrição, no contexto da prevenção e repressão às infrações contra a ordem econômica: a Lei n. 12.529, de 30 de novembro de 2011 ("Lei 12.529/11”) determina que a prescrição seja suspensa durante a vigência do compromisso de cessação ${ }^{379}$.

\footnotetext{
377 Importante a distinção dos efeitos provocados pela interrupção e pela suspensão da prescrição: se na interrupção os prazos prescricionais afetados deveriam ter sua contagem reiniciada a partir do momento em que cessasse a causa iterruptiva, na suspensão o prazo deixa de ser computado no momento da suspensão, sendo retomado logo após a extinção da causa suspensiva.

378 "Art. $3^{\circ}$ - Suspende-se a prescrição durante a vigência: [...] do termo de compromisso de que trata o $\S 5^{\circ}$ do art. 11 da Lei no 6.385, de 7 de dezembro de 1976, com a redação dada pela Lei no 9.457, de 5 de maio de 1997."

${ }^{379}$ Artigo 46, parágrafo $2^{\circ}$.
} 
Adicionalmente, WELLISCH e SANTOS ${ }^{380}$ entendem que, desde a publicação da Lei n. 11.941, em 27 de maio de 2009, a simples apresentação de proposta de termo de compromisso é causa de interrupção do prazo de prescrição em relação aos fatos investigados, nos termos do novo inciso IV do artigo $2^{\circ}$ da Lei $9.873 / 99^{381}$.

Com adoção de tal raciocínio, os autores entendem ser possível ir além: sequer seria necessária a apresentação da proposta de acordo para a interrupção da prescrição; a mera indicação de interesse na celebração de termo de compromisso, sem que tenha sido ainda apresentada proposta, seria suficiente para provocar a interrupção da prescrição, por ser possível interpretar tal manifestação como tentativa expressa de solução consensual no âmbito da administração.

\footnotetext{
380 "E no que tange à quarta e derradeira causa interruptiva [da prescrição], incluída por força da Lei 11.941/2009, faz-se relevante observar que a mera proposta de celebração de termo de compromisso em relação aos fatos investigados é hábil a interromper o curso do prazo prescricional. Uma vez aceita a proposta de ajuste consensual, incidirá o art. $3^{\circ}$, II, da Lei 9.873/1999, permanecendo suspenso o prazo para o exercício da pretensão punitiva durante a vigência do compromisso assumido". (2010, p. 79).

381 “Art. $2^{\circ}$ - Interrompe-se a prescrição da ação punitiva: [...] IV - por qualquer ato inequívoco que importe em manifestação expressa de tentativa de solução conciliatória no âmbito interno da administração pública federal".
} 


\section{PARTE II - DISCIPLINA INFRALEGAL, PROCEDIMENTO E APLICAÇÃO}

A CVM, por determinação expressa do legislador de $1976^{382}$, tem poderes ${ }^{383}$ para regulamentar os temas tratados na Lei 6.385/76, entre os quais os termos de compromisso. Essa competência é bastante interessante do ponto de vista do órgão regulador, ao conferir-lhe certa autonomia e considerável agilidade em termos de atividade normativa, essencial para acompanhar a realidade socioeconômica subjacente ${ }^{384}$.

Reflexo desse poder normativo está na disciplina infralegal relacionada aos termos de compromisso. Estipuladas as premissas e o quadro geral na Lei 6.385/76, todo o detalhamento das regras e do procedimento para operacionalização dos termos foi objeto da D. CVM 390/01 e suas alterações posteriores, discutida, elaborada e editada pela $\mathrm{CVM}^{385}$.

\section{DELIBERAÇÃO CVM N. 390/01}

A Diretoria Colegiada da Comissão, em reunião realizada em 8 de maio de 2001, aprovou a Deliberação n. 390, com o objetivo de disciplinar questões práticas dos termos de compromisso. A D. CVM 390/01 busca estabelecer os encaminhamentos necessários para celebração de um termo de compromisso, direcionando a conduta dos

\footnotetext{
${ }^{382}$ Artigo $8^{\circ}$, I, da Lei 6.385/76: "Compete à Comissão de Valores Mobiliários: I - regulamentar, com observância da política definida pelo Conselho Monetário Nacional, as matérias expressamente previstas nesta Lei e na lei de sociedades por ações; [...]".

${ }^{383}$ Para maiores informações a respeito do poder normativo da CVM, inclusive discussão a respeito da constitucionalidade da normatização pela CVM, cf. ROCHA, B. O poder normativo de órgãos da Administração: o caso da Comissão de Valores Mobiliários. In: Revista de Direito Mercantil, Industrial, Econômico e Financeiro, n. ${ }^{\circ}$ 64, 1986, p. 47-69; SZTAJN, R. O poder normativo da CVM em face da Constituição de 1988. In: A Nova Ordem Constitucional: Aspectos Polêmicos. Rio De Janeiro: Forense, 1990, p. 472-485; SANTOS, A. P. dos; WELLISCH, J. S. M; BARROS, J. E. G.. Notas sobre o poder normativo da comissão de valores mobiliários: CVM na atualidade. In: Revista de Direito Bancário e do Mercado de Capitais, São Paulo, v.9, n.34, p.68-84, out/dez. 2006; MOREIRA, Ricardo Guimarães. Poder regulamentar da Comissão de Valores Mobiliários em face dos princípios da legalidade e separação de poderes. In Revista de Direito Mercantil, v. 131, pp. 122-143; e um trabalho elaborado pela CVM em 1979 ("Regulação do mercado de valores mobiliários: fundamentos e princípios"), que teve trechos transcritos por TANURE, F. A responsabilidade administrativa no mercado de valores mobiliários. Monografia apresentada ao Instituto de Economia da UFRJ, em julho de 2005, pp. 11-12.. Disponível em

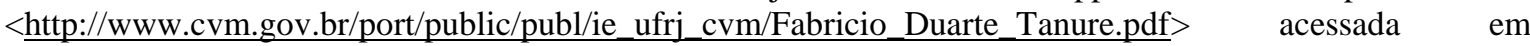
$15 \operatorname{set} 2011$.

384 "De ressaltar que até a promulgação da Constituição de 1988, o poder normativo da CVM tinha, em construção doutrinária de delegação de poderes do Executivo para a autarquia, seu fundamento. A mudança constitucional que restringe essa delegação, pode causar problemas uma vez que muitas instruções normativas têm conteúdo de lei. Contudo, a velocidade com que operações são esquematizadas (engenharia financeira é a denominação usual) requer que a CVM tenha poderes para organizar e disciplinar o mercado". SZTAJN $(2004$, p. 141).

385 " [....] diante da lacuna da lei e objetivando regulamentar, de maneira mais clara, o instituto do termo de compromisso, a Comissão de Valores Mobiliários, em 8 de maio de 2001, expediu a Deliberação n. 390" (CARVALHOSA e EIZIRIK, 2002, p. 519).
} 
administrados e também dos agentes públicos encarregados da execução das tarefas da Comissão.

Exemplificativamente, a D. CVM 390/01 inclui especificação de conceitos já grafados na Lei 6.385/76, como o funcionamento da suspensão dos procedimentos administrativos prevista no parágrafo $5^{\circ}$ do artigo 11 dessa Lei e a forma de decisão da CVM a respeito dos termos. Enquanto a Lei apenas indica a possibilidade de suspensão, pela Comissão, a Deliberação informa que a suspensão será pelo prazo necessário ao cumprimento do acordo ${ }^{386}$, e que a decisão sobre aceitação ou recusa das propostas caberá à Diretoria dessa autarquia, em deliberação colegiada ${ }^{387}$. Também repete ou parafraseia regras legais, como em seu artigo $4^{\circ}$, cujo teor é praticamente idêntico ao do parágrafo $6^{\circ}$ do artigo 11 da Lei 6.385/76.

A seguir são apresentados os procedimentos disciplinados na D. CVM 390/01, já referindo as alterações incluídas por normativos posteriores, os quais serão objeto de tratamento específico.

\subsection{Requisitos}

A D. CVM 390/01, em seu artigo $7^{\circ}$, caput, estabelece as condições para a apresentação de proposta de termo de compromisso, praticamente reproduzindo os incisos do parágrafo $5^{\circ}$ do artigo 11 da Lei $6.385 / 76$, exceto por inserir a expressão "se for o caso" após mencionar a necessidade de cessação das condutas, e afirmando que devem ser indenizados, no contexto de correção de irregularidades apontadas, os prejuízos "causados ao mercado ou à CVM".

Tais complementações, autoexplicativas, não demandam aprofundamentos.

\subsection{Procedimento}

A seguir serão tratadas questões procedimentais, como as regras aplicáveis à delimitação das etapas do procedimento administrativo em que é possível apresentar proposta de termo de compromisso; qual deve ser o conteúdo de tal proposta; quem são as partes, inclusive com referência à participação de terceiros lesados como informantes, sem que sejam alçados à condição de parte do acordo, entre outras.

\subsubsection{Fases em que é possível apresentar a proposta}

\footnotetext{
${ }^{386}$ Artigo $2^{\circ}$ da D. CVM 390/01.

${ }^{387}$ Artigo $3^{\circ}$ da D. CVM 390/01.
} 
O momento adequado para apresentação e aceitação da proposta de acordo é um tema em que há margem para discussão e argumentação.

ARAGÃO e SANTOS, ainda antes da positivação dos termos de compromisso na disciplina legal do mercado de valores mobiliários brasileiro, ancorando-se no modelo americano, mostraram-se partidários de que seria necessário o desenvolvimento de uma atividade de investigação sólida antes da aceitação de qualquer acordo ${ }^{388}$.

No mesmo sentido foi a manifestação da extinta Procuradoria Jurídica da CVM, tanto antes ${ }^{389}$ como depois de $1997^{390}$. Na primeira manifestação sobre o tema, disse ser necessário ao menos um inquérito administrativo instaurado, para serem "aprofundadas as averiguações" necessárias ao dimensionamento das condutas. Já na manifestação mais recente, não houve definição de momento processual, mas foi evidenciada preocupação quanto à "importância de se obter uma exata noção dos fatos sob investigação", para que ilícitos mais graves não fossem desconhecidos da administração. Sugere, ainda, medida que aparenta ser interessante: o diferimento do momento da apreciação da proposta em relação à proposição do acordo, para que sejam reunidas informações suficientes à adoção de uma decisão informada.

Tal entendimento, inclusive, já foi apontado como possível fator justificador da impossibilidade de a CVM celebrar termos de compromisso previamente à instauração de inquérito administrativo, quando seria feita a devida apuração da extensão das irregularidades cometidas ${ }^{391}$, e a consequente mensuração do dano a investidores ou ao mercado. Atualmente, tal conceito não vem sendo mais assim interpretado, como explicitado mais adiante.

A Lei 6.385/76 não é específica e tampouco limitadora da ação discricionária da Comissão quando determina, no artigo instituidor dos acordos administrativos no

\footnotetext{
388 “ $[. .$.$] antes de instaurado o inquérito e antes de realizadas as investigações que caso a caso se fizerem$ necessárias, a aceitação de qualquer tipo de 'settlement' teria como lastimável consequência, a curto prazo, uma consciência no mercado e no âmbito das companhias abertas de que, cometida a falta, bastaria ao autor do ato ilícito ou da prática não equitativa correr à CVM em busca de uma absolvição que, além do reconhecimento da responsabilidade civil, não the custaria mais do que 500 ORTN". ARAGÃ̃O e SANTOS $(1979$, p. 9).

389 "A realização de acordo não deve se dar sem instauração de inquérito administrativo [...] pelo fato de que nas investigações preliminares é apurada a possibilidade ou não de ter ocorrido um ilícito. No curso do inquérito é que são aprofundadas as averiguações que, eventualmente, poderão tomar proporções bem maiores do que as inicialmente apresentadas". (Parecer/CVM/SJU/93/83).

390 "Salientamos, no entanto, a importância de se obter uma exata noção dos fatos sob investigação, sem o quê infrações de natureza grave poderão ser ignoradas pela fiscalização. Portanto, o momento do oferecimento de uma proposta de acordo não precisa necessariamente coincidir com o momento de sua apreciação, podendo a CVM dar continuidade ao processo, se for conveniente ao melhor esclarecimento dos fatos sob investigação". (Parecer/CVM/PJU/005/98).

${ }^{391}$ Cf. Parecer/CVM/SJU/93/83.
} 
contexto dos processos sancionadores para apuração de infração às normas do mercado de valores mobiliários ${ }^{392}$, que "a Comissão de Valores Mobiliários poderá suspender, em qualquer fase, o procedimento administrativo, se o indiciado ou acusado assinar termo de compromisso [...]".

Considerando tal norma, era entendimento geral que a celebração poderia ocorrer em qualquer momento da apuração da infração, desde a instauração do processo administrativo, com a notificação do administrado ${ }^{393}$, até imediatamente antes do julgamento pelo Colegiado da Comissão ${ }^{394}$. Ainda que existissem questionamentos a respeito da possibilidade de serem os termos de compromisso celebrados pela CVM sem sequer essa autarquia estar certa da ilicitude da conduta sob investigação ${ }^{395}$.

A Diretoria Colegiada da Comissão, ao aprovar a D. CVM 390/01, decidiu que a apresentação da proposta de termo de compromisso deveria ser feita em estágio inicial dos procedimentos administrativos, ao estipular a necessidade de sinalização, pelo administrado, antes do final do prazo para apresentação de defesa administrativa, a respeito da existência de interesse na celebração de acordo, com entrega de requerimento à Comissão ${ }^{396}$. Após tal requerimento, com o escopo de evitar a coincidência do prazo da

\footnotetext{
392 Artigo 11 , parágrafo $5^{\circ}$, da Lei $6.385 / 76$, em sua redação primitiva.

393 Não sendo observada, então, a preocupação exposta por ARAGÃO e SANTOS, ainda em 1979 (p. 7), quanto à proposição de acordos ainda em fase de investigação preliminar: "Mesmo à vista dos modelos estrangeiros, entendemos prematura qualquer composição ou manifestação de conformidade por parte do acusado, antes da instauração formal do inquérito. Antes dessa etapa, a CVM estaria claramente abrindo mão de seu poder de investigar, com a indesejável consequência de, na maioria dos casos, deixar de apurar os aspectos do ato ilícito ou da pratica não equitativa necessários para assegurar a tutela do acionista minoritário. Realmente, se fosse facultado, ao intermediário ou ao administrador, desde logo procurar uma composição com a CVM quando se visse atingido por uma investigação preliminar, muita coisa ficaria sem apurar". É possível entender, entretanto, que a faculdade de apresentação de proposta ainda durante a fase de "sindicância" (conforme redação orignal da D. CVM 390/01), ou de "investigação preliminar", conforme nomenclatura das deliberações atualizadoras da D. CVM 390/01, não exclui a possibilidade de a CVM apenas apresentar posicionamento com relação à proposta após ter formado um juízo com relação às acusações e imputações, condutas potencialmente ilícitas e extensão de potenciais danos, informações importantes para a decisão sobre a conveniência e oportunidade de aceitar ou não qualquer acordo proposto.

394 " $O$ termo de compromisso poderá ser firmado em qualquer fase do processo administrativo, desde a notificação e a abertura do inquérito até o seu julgamento pelo Colegiado da CVM, já que a lei faz referência tanto ao indiciado ( $1^{\mathrm{a}}$ fase do processo administrativo) quanto ao acusado ( $2^{\mathrm{a}}$ fase do mesmo, que se inicia com o relatório da Comissão)". EIZIRIK (1998, p. 102). SANTOS et. al. (2012, p. 251) tratam o termo final da mesma forma: "[...] uma vez emitida a decisão administrativa de primeira instância, opera-se a preclusão administrativa e, em consequência, resta inviabilizada a celebração do ajuste contratual”.

${ }^{395}$ Uma das objeções do Professor SALLES (1997 p. 113), tratada e contestada no item 4.2 .1 supra: "Como afirma Eizirik [citando aqui a obra de Reforma da Lei das S.A. e mercado de capitais, de 1997, p. 249] 'nesta fase do processo administrativo, na realidade as condutas estão sob investigação, para apuração de eventuais irregularidades ou ilegalidades', pelo que concluímos que a CVM, ao intentar o acordo, não tem como afirmar da ilicitude!".

${ }^{396}$ Conforme disciplinado pelo artigo $8^{\circ}$ e seu parágrafo único da D. CVM 390/01, pela redação original, e pelos parágrafos $1^{\circ}$ e $2^{\circ}$ do artigo $7^{\circ}$, considerando as modificações sofridas pela norma.
} 
elaboração da proposta com aquele destinado à preparação da defesa, seriam concedidos 30 (trinta) dias adicionais para submissão da proposta completa ${ }^{397}$.

Como seria esperado - uma vez que essa medida restringe o planejamento e ação dos administrados diante de procedimentos administrativos -, existiram questionamentos a respeito de tal decisão, essencialmente com fundamento na impossibilidade de uma Deliberação da Comissão de Valores Mobiliários restringir direito dos administrados assegurado em lei.

Em Despacho proferido no Inquérito Administrativo CVM n. 33/00, o então Relator, Diretor Wladimir Castelo Branco Castro, explicou que, com base na discricionariedade da CVM, inclusive confirmada pelo Decreto 3.995/01 ${ }^{398}$,

\begin{abstract}
"[...] o Colegiado da CVM, no exercício de tal poder discricionário, ao editar a Deliberação no 390/2001, considerou inoportuna a apresentação de propostas de celebração de termo de compromisso em estágio avançado do processo administrativo, o que viria mesmo a frustrar a finalidade do instituto, que visa a uma solução mais efetiva e rápida do processo, contemplando, inclusive, uma indenização tempestiva dos prejuízos eventualmente causados pela conduta investigada".
\end{abstract}

A regra editada pela CVM configurou, portanto, medida de operacionalização e tentativa de padronização quanto ao momento em que a Comissão entendeu ser mais proveitoso ao interesse público, para orientar os administrados. Principalmente por ser a aceitação ou recusa dos acordos de livre (e fundamentada) decisão da Comissão, não parece ser absurda dita regulamentação.

Foi apresentado, sobre o mesmo tema, "Pedido de Revisão do Art. $8^{\circ}$ da Deliberação", subscrito por escritórios de advocacia ${ }^{399}$, entendedores de que "não pode haver delimitação de prazo para propor a celebração de Termo de Compromisso, como consta do artigo $8^{\circ}$ da Deliberação CVM no 390 , uma vez que a Lei $n^{\circ} 6.385 / 76$ não estipula qualquer restrição nesse sentido, sendo certo que uma norma de hierarquia inferior não pode contrariar outra superior”.

Registrou o Relator, Diretor Wladimir Castelo Branco de Castro, que os solicitantes da revisão fundamentaram seu pleito com a afirmação de que "como 'a lei

\footnotetext{
${ }^{397}$ Naturalmente era facultado aos agentes do mercado intimados a apresentação de proposta antes do prazo de 30 dias, sendo viável até mesmo a apresentação de proposta antes de intimação. A Comissão estabeleceu um termo final ao prazo para submissão de propostas, mas não um termo inicial, que segue coincidindo com a própria adoção da conduta potencialmente ilícita.

${ }^{398}$ Referido no item 5, ao elucidar a redação e tornar ainda mais evidente que a aceitação das propostas de acordo de termo de compromisso estão condicionadas ao juízo de conveniência e oportunidade da Comissão. ${ }^{399}$ Processo CVM RJ N. 2003/0818.
} 
faculta à CVM a possibilidade de suspender o procedimento administrativo a qualquer tempo a fim de apreciar o termo de compromisso', tal disposição normativo [sic] viria a permitir ao acusado 'apresentar proposta de celebração do referido termo, também em qualquer tempo"”.

O Diretor então consultou a Procuradoria Federal Especializada, que assegurou a legalidade da regra questionada ${ }^{400}$, em síntese, porque a Lei fala no momento da celebração do termo de compromisso, sem especificá-lo, enquanto que a D. CVM 390/01 trata de limitar prazo para a apresentação da proposta, sem pretender modificar as disposições legais. A própria Procuradoria, porém, demonstrando proatividade e interesse, informou que talvez fosse o caso de reavaliar a limitação temporal, ou eventualmente flexibilizá-la, para conferir mais efetividade aos acordos administrativos, considerando o interesse na indenização de prejudicados, a qual pode ser vantajosa, ainda que a submissão de minuta de acordo seja feita mais tardiamente. A Procuradoria Federal Especializada sugeriu, por fim, que fosse o momento de apresentação da proposta não um limitador da submissão de pedidos de acordo, mas um critério para avaliar os termos ofertados pelos particulares.

Em linha com o pensamento da douta Procuradoria, é possível reconhecer que a demasiada rigidez no estabelecimento de prazo para a propositura do termo de compromisso, se por um lado dá maior agilidade ao andamento do procedimento administrativo, evitando a interposição de propostas com fins meramente procrastinatórios, por outro pode vir a prejudicar o fim ao qual se destina, quando esse fim coincidir com a celebração do termo, ainda que proposto tardiamente.

Assim, tendo em vista o caráter discricionário que, norteado pelo dever de salvaguarda do interesse público, envolve a celebração de termo de compromisso por parte da CVM, entende-se que a sugestão da PFE - de, no lugar do estabelecimento de prazo para apresentação de propostas de compromisso seja incluído, dentre os critérios de avaliação de tais propostas, o momento de sua apresentação - mereceria ser acatada por representar uma evolução que o instituto vem demandando.

\footnotetext{
${ }^{400}$ Compartilhando entendimento da PFE, CUEVA (2007, p. 298) entende ser correta e salutar a limitação temporal, como regra geral: "Por fim, a restrição, imposta no regular exercício do poder discricionário da CVM, atende ao princípio da razoabilidade, na medida em que, após a apresentação da defesa - momento processual que se segue às frequentemente extensas investigações preliminares e à deliberação do colegiado da autarquia que acolhe a acusação e determina a intimação dos acusados pra se defenderem -, já se encontram reunidos, em princípio, os elementos de fato e de direito suficientes à prolação do julgamento, não se justificando a celebração do compromisso".
} 
O Relator do caso em exame felizmente concordou com as colocações da Procuradoria, inclusive sugerindo que fossem estudadas alterações à disciplina normativa, as quais vieram a ser positivadas na forma da Deliberação CVM n. 486, de 17 de agosto de 2005 (“D. CVM 486/05”).

Uma das regras modificadas pela D. CVM 486/05, originada de Audiência Pública, conforme referido no item 10 abaixo, foi exatamente a referida pela Procuradoria e pelo Relator do caso citado acima, com a criação de uma regra extraordinária, a ser aplicada em casos específicos. Tal regra ${ }^{401}$ conferiu ao Diretor sorteado relator de cada um dos procedimentos administrativos a faculdade de propor ao restante do Colegiado a análise de proposta de termo de compromisso apresentada fora do prazo regulamentar mantido inalterado o parâmetro de 30 (trinta) dias após a protocolização da defesa administrativa -, desde que, cumulativamente, assim seja determinado pelo interesse público (exemplificativamente, com oferta de indenização substancial aos lesados pela conduta apurada no procedimento), e fique demonstrada modificação na situação de fato, em relação ao momento do término do prazo regular, que justifique a não observância de tal prazo.

Durante a vigência de tal regra, é possível identificar casos em que Diretores integrantes do Colegiado da CVM entenderam preenchidos os requisitos cumulativos ${ }^{402}$, e casos de votos contrários à aceitação de propostas ${ }^{403}$, com fundamento no não atendimento das exigências cumulativas impostas pela D. CVM 486/05 para caracterização dos casos excepcionais, em que é possível a aceitação de proposta de acordo fora do prazo regulamentar.

Seguindo o projeto de contínuo melhoramento das normas aplicáveis ao mercado de valores mobiliários, a CVM editou a Deliberação n. 657, em 7 de fevereiro de

\footnotetext{
${ }^{401}$ Artigo $7^{\circ}$, parágrafo $4^{\circ}$, da D. CVM 486/05: "Em casos excepcionais, nos quais o Relator entenda que o interesse público determina a análise de proposta de celebração de termo de compromisso apresentada fora do prazo a que se refere o $\S 2^{\circ}$, tais como os de oferta de indenização substancial aos lesados pela conduta objeto do processo, e desde que, adicionalmente, fique demonstrada a modificação da situação de fato, existente quando do término do referido prazo, a justificar a não apresentação tempestiva, o Colegiado poderá determinar, por proposta do Relator, o processamento do pedido".

${ }^{402}$ Exemplificativamente, voto do então Diretor Eli Loria na apreciação da segunda proposta apresentada pelos acusados no Processo Administrativo Sancionador RJ2006/4665, aprovada em 10 de novembro de 2009.

${ }^{403}$ Voto vencido do Diretor Eli Loria, na apreciação de nova proposta, majorada de $\mathrm{R} \$ 3.000 .000,00$ (três milhõe de reais) para $R \$ 15.000 .000,00$ (quinze milhões de reais), em que entendeu inexistir atendimento dos requisitos, vez que "sem justificativa para a sua não apresentação tempestiva". A proposta, entendida como adequada pela Procuradoria Federal e Comitê de Termo de Compromisso, foi aprovada pelo voto dos outros quatro membros da Diretoria, em 15 de dezembro de 2009, pois "consideraram que a proposta de termo de compromisso apresentada representaria compromisso suficiente para inibir a prática de condutas assemelhadas, em atendimento à finalidade preventiva do instituto do termo de compromisso".
} 
2011 (“D. CVM 657/11”), estabelecendo que "em casos excepcionais justificados pelo interesse público, o Colegiado apreciará proposta de termo de compromisso apresentada, fora do prazo regulamentar, pelo acusado interessado", eliminando "a exigência, até então vigente, de modificação da situação de fato existente quando do término do prazo para apreciação da proposta apresentada fora do prazo"404.

Pela nova regra, passou-se a enquadrar a mudança de situação fática e a indenização substancial aos prejudicados como exemplos de circunstâncias em que o interesse público pode determinar a apreciação de oferta de termo de compromisso fora do prazo regulamentar (inalterado pela D. CVM 657/11, tendo sido mantido desde a D. CVM 390/01 original), e não mais como requisitos cumulativos.

Tal modificação, naturalmente, ampliou a discricionariedade do Colegiado da Comissão, praticamente excluindo qualquer impeditivo de apresentação e apreciação, a qualquer tempo, de proposta (ou propostas) de termo de compromisso em qualquer processo administrativo sancionador ${ }^{405}$.

Outra alteração digna de nota foi a eliminação da decisão monocrática do Diretor Relator a respeito da admissibilidade e encaminhamento de minutas de termos de compromisso nos chamados "casos excepcionais". Atualmente cabe ao órgão Colegiado, independentemente do Diretor que tenha sido designado para relatar o processo sancionador, avaliar a excepcionalidade de tais pleitos.

Com relação ao termo inicial, inexistem restrições na Lei 6.385/76 ou nas Deliberações, sendo inclusive expresso na disciplina infralegal aplicável que deve ser

\footnotetext{
404 Conforme comunicado divulgado no website da Comissão. Disponível em: <http://www.cvm.gov.br/port/infos/Comunicado\%20Alteradora\%20da\%20Deliberacao\%20390\%20vf.asp >. Acesso em 25maio2012.

${ }^{405}$ Porque escorada na possibilidade de apresentação de propostas para celebração de termo de compromisso a qualquer tempo (em casos excepcionais) vigente em exame, é oportuna a análise a respeito do comportamento dos acusados na apresentação de proposta às vésperas da sessão de julgamento. Questiona-se especificamente se tal expediente configura abuso do administrado, ou pode ser enquadrado como ação dentro de seu direito de propor acordos à Comissão, conforme previsto em lei e disciplinado na D. CVM 390/01, conforme alterada, cabendo à CVM recusar ou aceitar, dentro de seu juízo de discricionariedade, regido pelo binômio conveniência-oportunidade.

Parece correta a segunda assertiva, e a Comissão tem se mostrado firme repelindo adequadamente tais comportamentos quando inaceitáveis, como no exemplo de aditamento à proposta de termo de compromisso apresentada no contexto do Processo Administrativo Sancionador 27/05, julgado em 12 de junho de 2012. Verifica-se no voto condutor do julgamento, da lavra do Diretor Otavio Yazbek, que "três dos acusados apresentaram, neste momento, novas propostas de termo de compromisso, comprometendo-se a pagar quantias ligeiramente superiores às que já foram analisadas e rejeitadas pelo Colegiado. Tais propostas, porque realizadas por só uma parte dos acusados, porque flagrantemente insuficientes e porque apresentadas às vésperas do julgamento, não trariam significativa economia processual. Por esses motivos, proponho a rejeição das propostas de termo de compromisso apresentadas, em 08.06.2012, pelos acusados [Acusados], por absolutamente inoportunas". Como se vê, cabe à CVM afastar condutas oportunistas ou aceitar propostas apresentadas ou reapresentadas fora do prazo usual, caso interessantes à busca do interesse público.
} 
“admitida a apresentação de proposta de celebração de termo de compromisso ainda na fase de investigação preliminar"406.

Há exemplos inclusive de celebração de acordo entre a CVM e particulares anteriormente ao próprio início das investigações, mesmo preliminares, os quais evidenciam tal possibilidade, de maneira concreta. É possível citar o acordo proposto e aceito nos autos do Processo Administrativo 2007/12.581 407 , em que determinado fato chegou ao conhecimento da CVM por uma consulta, a respeito de operação previamente concluída. Simultaneamente à apresentação dos fatos à Comissão, já antevendo a hipótese de a transação em questão ser entendida como irregular, o administrado consulente submeteu proposta de termo de compromisso. Sedimentado o entendimento do Colegiado no sentido da irregularidade da situação apresentada, foi aceita a proposta e celebrado o acordo.

Considerando a discricionariedade na análise das propostas, é possível que, em $\operatorname{outros} \operatorname{casos}^{408}$, a Comissão entenda serem necessários aprofundamentos na apuração das condutas e fatos, antes da emissão de juízo de valor, inclusive quanto aos requisitos essenciais (interrupção da conduta e, principalmente, mensuração de eventuais danos).

Vale, por fim, menção à experiência no âmbito concorrencial sobre o momento da apresentação de proposta para celebração de acordo ${ }^{409}$, sobretudo no que concerne à evolução legal ocorrida. Em sua redação original, a Lei 8.884/94 assegurava a possibilidade de celebração dos compromissos de cessação em qualquer fase do processo administrativo $^{410}{ }^{411}$. Após alterações realizadas pela Lei $11.482 / 07$, a apresentação da

\footnotetext{
${ }^{406}$ Redação atual da D. CVM 390/01, especificamente em seu artigo $7^{\circ}$, parágrafo $3^{\circ}$.

${ }^{407}$ Citado por WELLISCH e SANTOS $(2009$, p.3).

${ }^{408}$ Exemplificativamente, na apreciação de proposta de acordo relacionada ao Processo Administrativo Sancionador CVM n. RJ 2010/7309, em que o Comitê de Termo de Compromisso registrou, em parecer de 28 de setembro de 2011, que "não obstante a possibilidade de apresentação de proposta de Termo de Compromisso previamente à eventual instauração de processo administrativo sancionador por esta CVM, há casos em que não se verificam elementos suficientes a permitir ao Comitê a emissão de um juízo de valor que viabilize a própria celebração do Termo de Compromisso, mormente sob a ótica do atendimento dos requisitos legais aplicáveis. No entender do Comitê, tal situação sucede no presente caso, considerando notadamente a fase de investigação em que se encontra o procedimento administrativo, bem como a inexistência de suficiente clareza em relação às possíveis responsabilidades e aos eventuais prejuízos suportados pelos fundos. Há que se observar que, embora a afirmação de certeza quanto à existência ou não de dano demande um juízo definitivo incompatível com o instituto do Termo de Compromisso de que trata a Lei $\mathrm{n}^{\circ}$ 6.385/76, faz-se necessário ao Comitê a existência de elementos mínimos que lhe permitam uma análise da proposta sob o ângulo do requisito de que trata o inciso II do $\S 5^{\circ}$ do art. 11 da Lei $\mathrm{n}^{\circ} 6.385 / 76$, para fins de viabilizar a recomposição do potencial dano e, portanto, o próprio posicionamento final acerca da celebração do Termo de Compromisso".

${ }^{409}$ Cuja pertinência, como mencionado no item 4.5, decorre do enfrentamento de temas polêmicos que podem vir a ser relevantes na disciplina dos termos de compromisso no mercado de valores mobiliários.

410 “Art. 53. Em qualquer fase do processo administrativo poderá ser celebrado, pelo CADE ou pela SDE ad referendum do CADE, compromisso de cessação de prática sob investigação, que não importará confissão quanto à matéria de fato, nem reconhecimento de ilicitude da conduta analisada".
} 
proposta passou a ser limitada temporalmente ao início da sessão em que seja julgado o processo administrativo relacionado à conduta a respeito da qual poderia ser celebrado compromisso de cessação ${ }^{412}$.

Diferente foi o tratamento imaginado quando da elaboração da Lei 12.529/11. $\mathrm{O}$ projeto que a originou, conforme aprovado pelo Legislativo, previa um parágrafo $3^{\circ}$ ao artigo $85^{413}$, limitando o momento da apresentação da proposta do compromisso de cessação. A proposição de acordo poderia ocorrer exclusivamente até o final da fase de instrução do processo administrativo em que se apurasse a conduta sobre a qual versaria o termo. A Mensagem 536, de 30 de novembro de 2011, trouxe veto parcial da Presidência da República a excertos do que viria a ser a Lei 12.529/11, amparado em manifestação do Ministério da Justiça. Entre os artigos e parágrafos objeto de veto figurou o parágrafo $3^{\circ}$ ao artigo 85 e, especificamente com relação a tal regra, o fundamento para o veto seria “contrariedade ao interesse público", pois sua aprovação causaria restrição à "possibilidade de celebração de acordos à etapa de instrução dos processos, limitando indevidamente um instrumento relevante para atuação do Tribunal na prevenção e na repressão às infrações contra a ordem econômica" ${ }^{\text {414. }}$.

Portanto, hodiernamente, não há restrição legal quanto ao momento de celebração dos termos de compromisso de cessação pelo $\mathrm{CADE}^{415}$, ficando a critério do Plenário do Tribunal Administrativo de Defesa Econômica, em juízo de conveniência e oportunidade, aprovar a assinatura dos termos de compromisso ${ }^{416}$.

Ainda a respeito do início do procedimento de análise e discussão dos acordos administrativos, cumpre indicar outra diferença entre apresentação do termo de

\footnotetext{
${ }^{411}$ Entende também a doutrina que, estando ainda em curso a apuração da infração, cabe a pactuação do acordo: "A Lei determina que, estando pendente o Processo Administrativo, o compromisso de cessação poderá ser celebrado. E nem seria admissível coisa diversa, pois o acordo não poderia alcançar sanção já aplicada pela Administração, desconstituindo-a". GRAU e FORGIONI (2005, p. 239.).

412 "Art. $53[\ldots] \S 3^{\circ} \mathrm{A}$ celebração do termo de compromisso poderá ser proposta até o início da sessão de julgamento do processo administrativo relativo à prática investigada".

413 "[...] $\S 3^{\circ}$ A celebração do termo de compromisso poderá ser proposta até o encerramento da instrução do processo administrativo relativo à prática investigada".

${ }_{414}$ Mensagem 536, de 30 de novembro de 2011, especificamente em seu preâmbulo e nas "Razões do Veto" ao parágrafo $3^{\circ}$ ao artigo 85 .

${ }^{415}$ Merece referência a observação de SAITO $(2011$, p. 29), no sentido de que "Quanto mais se aproxima da data do julgamento, conclui-se que foram reunidas provas suficientes para o convencimento do Conselheirorelator. Dessa forma, quando o caso é pautado para julgamento, o SBDC já possui material suficiente para decidir e fica difícil a possibilidade de oferecimento de benefícios pelo administrado". A mesma autora traz síntese de caso exemplificativo (Processo Administrativo 08212.003805/2004-10), em que proposta de termo de compromisso às vésperas do julgamento do caso foi rejeitada. A Procuradoria do CADE manifestou-se no sentido de que a paralisação (e consequente atraso) do processo naquele momento prejudicaria o interesse público, observou que haviam sido apresentadas provas suficientes para um julgamento instruído, e não existiriam benefícios à sociedade ou à Administração.

${ }^{416}$ Nos termos do artigo $9^{\circ}$, V, da Lei 12.529/11.
} 
compromisso na seara da tutela da concorrência e no mercado de valores mobiliários: a iniciativa da apresentação.

Enquanto nos termos de compromisso disciplinados pela Lei 6.385/76 e pela D. CVM 390/01 (especificamente no artigo $7^{\circ}$ desta última) a iniciativa da solicitação do acordo é obrigatoriamente do próprio investigado ou processado ${ }^{417}$ (embora deva constar, obrigatoriamente, referência à possibilidade de proposição de termo de compromisso em todas as intimações expedidas pela $\mathrm{CVM}^{418}$ ), naqueles celebrados sob o regime da Lei 12.529/11 é possível, além da usual solicitação de celebração de acordo por parte do investigado, que o requerimento para celebração de termo de compromisso de cessação de prática possa ser apresentado pela Superintendência-Geral ${ }^{419}$ ou por um dos Conselheiros ${ }^{420}$. Em tais casos, o representado é oficiado e deve manifestar seu interesse em iniciar a negociação de um acordo com a administração. Havendo tal interesse do administrado, são iniciadas as negociações, retomando-se o curso usual do procedimento $^{421}$.

Por outro lado, caso o administrado rejeite a solicitação do CADE, naquele momento, seguem-se os trâmites processuais regulares, sendo conservado o direito do representado de apresentar um novo requerimento, pleiteando a celebração de termo de compromisso, quando e caso entenda ser oportuno.

Evidentemente, seguindo a lógica consagrada da ferramenta, pela qual a celebração de um acordo se constitui em faculdade da administração e não um direito subjetivo do agente econômico, tal requerimento poderá ser aprovado ou não pela autoridade $^{422}$.

\subsubsection{Conteúdo da proposta}

Seguramente os requisitos essenciais - cessação da prática sob investigação e correção das irregularidades apontadas - devem estar presentes na proposta de celebração

\footnotetext{
${ }^{417}$ Ainda que exista a negociação pelo Comitê de Termo de Compromisso, tratado no item 9.2.4.1, infra, a iniciativa é, obrigatoriamente, do agente econômico cuja conduta está sendo apurada, ao menos formalmente. ${ }^{418}$ Conforme estabelecido pelo artigo 13, parágrafo $4^{\circ}$, da D. CVM 538/08.

${ }^{419}$ Artigo 13, IX, da Lei 12.529/11 e artigo 181 do RI-CADE.

${ }^{420}$ Artigo 11, IX, da Lei 12.529/11.

${ }^{421}$ O artigo L621-14-1 do Code monétaire et financier francês prevê que a proposta da chamada composition administrative (que guarda similitudes aos termos de compromisso nacionais) é de iniciativa exclusiva da autoridade. Tal regra acarreta uma mudança essencial: apenas a certos administrados é facultado o acordo, e a avaliação a respeito da conveniência e oportunidade é feita pelo órgão regulador antes da intimação, já acompanhada da proposta, quando pertinente.

${ }^{422}$ Artigo 181 , parágrafo $1^{\circ}$, do RI-CADE.
} 
de termo de compromisso, conforme já examinado ${ }^{423}$. Considerando a discricionariedade e a liberdade concedida, é possível que outras obrigações ${ }^{424}$ sejam incluídas no acordo, além das essenciais ${ }^{425}$. Acrescente-se que, “consoante posicionamento já consolidado [...], a conduta a que o administrado já está obrigado por força de normativos legais não deve ser objeto de termo de compromisso" 426 .

É comum a repetição, na proposta, da regra do parágrafo $6^{\circ}$ do artigo 11 da Lei 6.385/76, pelo qual se definiu a não confissão em relação às matérias fáticas apontadas e o não reconhecimento de ilicitude da conduta analisada, embora não se faça necessário. 423 Cf. item 4.3 acima.
424 "No início, os administrados geralmente obrigavam-se a ministrar seminários ou a elaborar material
educativo a ser distribuído aos investidores, a par daqueles deveres inerentes à cessação da prática
considerada ilícita, como treinamento de funcionários e desenvolvimento de controles internos. Em 2005 ,
houve um aumento de atribuição de valores à CVM, a diversos títulos, desde 'ressarcimento de despesas',
doação, 'multa', e até mesmo a título de reparação de danos causados à autarquia e também ao mercado de
capitais (PA RJ 2001/9705), podendo-se cogitar, quanto a este último, a ocorrência de dano a interesse difuso
no mercado de capitais [...]. Outras vezes, não se declina a que título os valores serão pagos à autarquia. A
partir de 2006, verifica-se corrente a obrigação de pagar determinada quantia à CVM, sem especificação
acerca do título a que isto se opera". TANJI (2009, pp. 101-102).

Outros exemplos de obrigações compromissadas: doação de livros em valor aproximado de $R$ \$ 20.000,00 (vinte mil reais), em atendimento a relação a ser fornecida pela Procuradoria Federal Especializada (termo firmado em janeiro de 2005, no Inquérito Administrativo CVM N. 08/02); doação de 240 livros, sendo 120 cópias da Lei das Sociedades por Ações e 120 cópias de manual de contabilidade (termo firmado em março de 2005, no Processo Administrativo Sancionador CVM N. 2003/5459); promoção de seminário, com elaboração de um impresso, e pagamento de cursos de pós-graduação/MBA para dois servidores da CVM, em instituições de ensino (termo firmado em outubro de 2005, no Processo Administrativo Sancionador CVM N. 12/2003); renúncia do direito sobre o qual fundamentadas três ações judiciais contra a CVM e pagamento de quantia à Comissão (termo firmado em maio de 2007, no Processo Administrativo Sancionador CVM N. RJ 2005/8134); renúncia à atuação no mercado de bolsa de valores e bolsa de mercadorias e futuros, por dois anos (termo firmado em setembro de 2009, no Processo Administrativo Sancionador CVM N. RJ 12/2004); custeio de estudo econômico sobre a eficiência do mercado de capitais brasileiro, a ser elaborado por instituição inglesa e pagamento de quantia à Comissão (termo firmado em janeiro de 2012, no Processo Administrativo Sancionador CVM N. 05/2008. Também merece nota a sequência de propostas para celebração de termo de compromisso, identificada quando um dos acusados no Processo Administrativo Sancionador 05/2008 ofereceu as seguintes prestações à CVM: (i) pagamento da quantia de $\mathrm{R} \$ 1.800 .000,00$ (um milhão e oitocentos mil reais), rejeitado em 29 de junho de 2010 por ser, no entendimento do Comitê de Termo de Compromisso - acompanhado pela Diretoria Colegiada, "desproporcional à reprovabilidade da conduta atribuída ao proponente [...] [e] inconveniente, frente às características que o permeiam, ao contexto em que se verificaram as infrações imputadas à proponente e à especial gravidade da conduta considerada ilícita"; (ii) pagamento da quantia de $\mathrm{R} \$ 2.000 .000,00$ (dois milhões de reais), rejeitado em 10 de maio de 2011, por, no entendimento do Colegiado, seguir desproporcional, sendo que o órgão ainda acrescentou justificativa à recusa no sentido de que "a celebração do Termo de Compromisso ora proposto não caracterizaria qualquer ganho para a Administração, em termos de celeridade e economia processual, já que o curso do processo prosseguiria em relação a outros acusados"; e (iii) pagamento da quantia de $\mathrm{R} \$ 600.000,00$ (seiscentos mil reais) combinado com o custeio da elaboração de "um estudo econômico sobre a eficiência do mercado acionário brasileiro e a elaboração de Relatório Final contendo o resultado do estudo, a serem desenvolvidos pela empresa internacional de consultoria Oxera Consulting Ltd.", aceito em 8 de novembro de 2011, pois o Colegiado então considerou que a obtenção dos resultados do estudo reveste-se de grande conveniência e utilidade para a atuação da CVM em favor do aperfeiçoamento do mercado brasileiro de capitais", vencido o Diretor Eli Loria, que entendeu pela rejeição do termo, pelos argumentos aceitos por todos anteriormente.

${ }^{425}$ Sobre o tema, o item 9.2.2 infra.

${ }^{426}$ Conforme registrado no Parecer do Comitê de Termo de Compromisso oferecido em 20 de junho de 2012, com análise de proposta formulada nos autos do Termo de Acusação CVM n RJ 2011/11171. 
O parágrafo $7^{\circ}$ do artigo 11 da Lei 6.385/76 demanda também a discriminação dos prazos para cumprimento das obrigações assumidas, tanto as essenciais quanto quaisquer outras.

Outra informação que pode constar das propostas é o compromisso de envio de comunicações ou publicação de editais para identificação ${ }^{427}$ e contato com terceiros lesados e que devem ser ressarcidos, observando previsão do artigo 11 da D. CVM $390 / 01^{428}$

Também é possível fazer constar no corpo da proposta a exclusão de determinado terceiro do rol de titulares de direito a indenização, como ocorreu no termo de compromisso firmado em 31 de maio de 2007, pelo acusado no Processo Administrativo Sancionador CVM n. SP 2005/0173. Nesse caso, o texto contemplava uma Cláusula $4^{\mathrm{a}}$ determinando que "não será objeto do presente TERMO DE COMPROMISSO a reclamação feita pelo Sr. [Terceiro], haja vista transação ocorrida no âmbito do processo n. ${ }^{\circ}$ 2002.01.1.110707-6, que tramitou perante o $1^{\circ}$ Juizado Especial Cível de Brasília Distrito Federal".

Quanto aos valores pagos à Comissão, nos casos em que não há terceiros a indenizar, ou nos termos em que a CVM entender ser conveniente pagamento como

\footnotetext{
427 Interessante aspecto suscitado em Termo de Compromisso firmado pelo acusado no Processo Administrativo CVM n. RJ2007/1454, em que se comprometeu a fazer pagamento adicional a titulares de ações de determinada companhia de quem tivesse comprado ações em desacordo com a observância de regra que o obrigava a fazer oferta pública em decorrência de aumento de participação. Considerando as aquisições indevidas terem sido efetuadas em mercado de bolsa, o Colegiado entendeu que a indenização deveria ser paga a todos os investidores que tivessem alienado participação na sociedade, desde o momento em que o compromitente estaria obrigado a realizar a oferta pública, até a devida divulgação da oferta, excluídas as ações objeto de aquisição e alienação dentro do mesmo período (para que não fossem pagas várias indenizações pela mesma ação, caso transitasse pela esfera patrimonial de vários investidores, dentro do período apontado). Também por serem operações em mercado de bolsa, e o compromitente desconhecer os investidores que deveriam receber indenização, o Comitê de Termos de Compromisso obteve a relação dos investidores que deveriam ser ressarcidos junto à então Bovespa. O Colegiado, com o escopo de preservar o sigilo dos investidores que realizaram as operações na Bolsa de Valores, decidiu que deveriam autorizar, individualmente, em resposta a ofício remetido pelo Comitê, a transmissão de seus dados para que o compromitente pudesse fazer o pagamento da indenização compromissada, sem que se configurasse infração ao dever de sigilo das informações dos agentes lesados. Incluído, então, um parágrafo $3^{\circ}$ à Cláusula $1^{\mathrm{a}}$ do termo de compromisso firmado em 9 de julho de 2008, determinando que "os destinatários da indenização serão individualmente cientificados pela CVM, a fim de autorizarem o fornecimento ao COMPROMITENTE de todas as informações necessárias para o seu pagamento".

${ }^{428}$ Como ocorreu, por exemplo, no termo de compromisso firmado em 28 de fevereiro de 2008, em decorrência de proposta aprovada no Processo Administrativo Sancionador CVM n. RJ2006/3616, em que foi pactuada cláusula determinando que "em relação aos cotistas que não mais figurarem como clientes da [Sociedade], os COMPROMITENTES assumem o compromisso de enviar-lhes correspondência com aviso de recebimento (AR mãos próprias) convocando-os a comparecer para receberem os créditos a que fizerem jus ou a informar nova conta de depósito para realização do pagamento ("Correspondência"). Os COMPROMITENTES obrigam-se ainda a, caso necessário, publicar edital, cuja redação deverá ser previamente submetida à aprovação da CVM, por 3 (três) dias, em jornal de grande circulação do estado no qual estaria localizada a maioria dos cotistas que se busca atingir, convocando-os a receber os valores devidos".
} 
obrigação complementar ao ressarcimento de investidores lesados ${ }^{429}$, cujo objetivo é de desestimular a adoção de condutas assemelhadas ${ }^{430}$, é possível identificar termos de compromisso, no passado, que traziam em seu texto diversas classificações para tal pagamento, incluindo doação, ressarcimento de despesas ${ }^{431}$, multa $^{432}$ e reparação de danos a essa autarquia ou ao mercado.

Finalmente em $2006^{433}$, foi identificada tendência - inegavelmente mais técnica - de afirmar, no próprio instrumento e na deliberação que o aprova, que o pagamento é efetuado à Comissão a título de condição de aceitação do termo de compromisso.

Também deve estar contida no teor do acordo, em observância ao artigo $5^{\circ}$, parágrafo $1^{\circ}$, da D. CVM 390/01, a periodicidade com que o compromitente prestará contas à Comissão a respeito do adimplemento do pactuado, naturalmente apenas nos casos em que for aplicável.

\subsubsection{Partes da proposta - exclusão de terceiros prejudicados}

Inegavelmente uma das principais vantagens na adoção dos termos de compromisso é a possibilidade de garantir a terceiros lesados (assim entendidos aqueles não participantes da relação de fiscalização e potencial sancionamento estabelecida entre a CVM e os agentes do mercado de valores mobiliários, cuja conduta está sob apuração) a

\footnotetext{
${ }^{429}$ Segundo TANJI $(2009$, p. 99), "Nos últimos anos, conforme a seguir demonstrado, foi utilizado pela CVM também para obter reparação de danos causados à confiabilidade e ao regular funcionamento do próprio mercado de capitais, sob o entendimento de que tal instrumento é apto a obter a proteção do interesse difuso lesado por danos assim caracterizados, à semelhança do termo de ajustamentoe de conduta prévio ou no curso de ação coletiva".

${ }^{430}$ CANTIDIANO (1999, p. 25) apresenta raciocínio que pode ser utilizado tanto para embasar o ressarcimento ao mercado quanto para justificar a necessidade de adoção de medidas, pelos compromitentes, cujos efeitos repercutam em todo o mercado: "O exercício de determinadas atividades econômicas, em certos setores de atividade, como acontece no mercado de capitais, não implica numa relação direta entre parte e contraparte, o que impede o agente econômico de, a tempo e hora próprios, detectar a imperfeição propositadamente criada para ludibriá-lo, de que resulta uma perda patrimonial originada exclusivamente para da atuação irregular daquele agente menos escrupuloso. Mais que isso, em decorrência da citada perda, que não fica circunscrita a poucas contrapartes do agente que atuou de modo ilícito, todo um segmento do mercado sofre, o que coloca em risco a credibilidade de todo o sistema".

431 "Muitas vezes, observou-se a utilização da rubrica 'ressarcimento de despesas incorridas com a instauração do processo administrativo'. Porém, em que pesa ser este o conteúdo da proposta, não se pode concordar que a autarquia a tenha aprovado sob este entendimento, pois é sabido que o rol das fontes de recursos da CVM encontra-se no art. $7^{\circ}$ da Lei n ${ }^{\circ} 6.385 / 1976 "$ " TANJI $(2009$, p. 102).

432 "[...] a multa perfaz penalidade administrativa que deve resultar de devido processo administrativo, encerrando indelegável poder de polícia da CVM sobre o mercado de capitais. Desta forma, a aceitação de proposta pelo Colegiado da CVM, logicamente, não pode ser interpretada como aceitação da qualidade aposta pelo proponente ao pagamento dos valores". TANJI $(2009$, p. 102).

${ }^{433}$ Os primeiros termos de compromisso que trataram do pagamento como condição para a aceitação do termo de compromisso foram os acordos celebrados pelos acusados nos Processos Administrativos Sancionadores CVM RJ 2003/5473 e RJ-2002-7017 (firmado em 9 de março de 2006) e no Processo Administrativo Sancionador CVM N. 10/04 (firmado em 28 de março de 2006).
} 
possibilidade de terem, mediante indenização, seu(s) prejuízo(s) recomposto(s) de maneira ágil, em comparação aos trâmites judiciais.

O acordo administrativo, porém, é celebrado exclusivamente pelo administrado (ou seus representantes ou "presentantes" ${ }^{434}$ ) e a Comissão de Valores Mobiliários (por seu Presidente). Terceiros, ainda que sejam beneficiados pelo pactuado, não firmam o acordo, seja na qualidade de anuentes ou de intervenientes.

A Lei 6.385/76 não faz qualquer menção a respeito da participação dos terceiros lesados na discussão do acordo. Embora nunca fosse entendida como vedada a participação dos terceiros nas discussões envolvendo as obrigações a serem $\operatorname{compromissadas~}^{435}$, a não previsão expressa da participação dos agentes lesados foi apontada como uma falha pela doutrina ${ }^{436}$.

A D. CVM 390/01, por outro lado, destinou dois artigos - 10 e 11 - à disciplina da relação dos terceiros com o procedimento de celebração dos termos. No primeiro deles, esclarece que a CVM pode notificar investidores lesados para que prestem informações a respeito dos danos sofridos, essencialmente quanto à sua quantificação, de forma que o acordo administrativo possibilite a recomposição adequada dos prejuízos sofridos.

Parece bastante recomendável o chamamento de tais indivíduos para que contribuam com a mensuração dos prejuízos, até porque podem vir a não apenas complementar informações existentes, como também contribuir com dados até então desconhecidos pela CVM. O parágrafo $1^{\circ}$ do artigo 10 da D. CVM 390/01 restringe a participação dos terceiros, qualificando-a como facultativa e limitando-a a matéria de seu interesse, qual seja, "prestação de informações relativas à extensão dos danos que tiver suportado e ao valor da reparação".

Adicionalmente, terceiros consultados não se tornam parte no acordo substitutivo, tampouco no processo administrativo pelo qual a proposta é analisada pela Diretoria Colegiada da Comissão ${ }^{437}$.

\footnotetext{
${ }^{434}$ Expressão referida por PONTES DE MIRANDA em seu Tratado de Direito Privado, Tomo I, §75, ao tratar do conceito de pessoa jurídica e da função de seus órgãos.

435 "Embora a lei silencie quanto à eventual participação de investidores lesados nas negociações que precederem ao acordo para suspensão do processo, não se vislumbra óbice a que tal ocorra, em especial quando uma das condições para a efetivação do termo de compromisso é a indenização de danos causados por práticas apuradas no curso do processo administrativo". Parecer/CVM/PJU/005/98.

436 "Por outro lado, há que se lembrar a figura do terceiro prejudicado, a quem a Lei 9.457/97 procurou resguardar com a indenização pelos prejuízos a ele causados pelo indiciado, sem que no entanto ao mesmo terceiro seja dado manifestar-se sobre sua quantificação, senão pela via judicial'". (SALLES, 1997, p. 113).

${ }^{437}$ Sobre o tema, sem razão SILVEIRA (2006, pp. 64-65), ao afimar, sobre a expressão "partes interessadas" que assinarão o instrumento do acordo, mencionado no artigo $3^{\circ}$, parágrafo $1^{\circ}$, da D. CVM $390 / 01$, que
} 
Como regra, "o eventual prejudicado não participa do termo de compromisso, sendo, dessa forma, sujeito estranho à relação". Isso faz com que o terceiro possa, independentemente da existência do acordo, "ingressar com ação de procedimento ordinário, visando a apuração dos fatos praticados pelo indiciado ou acusado no processo administrativo, requerendo reparação do dano sofrido, cuja quantia será fixada pelo juiz" ${ }^{, 438}$.

Também ao terceiro é facultado propor execução de quantias certas que tenham sido estabelecidas em termo de compromisso, ainda que não seja parte de tal acordo, considerando que o instrumento assegura a existência de crédito ${ }^{439}$.

Por ser o título executivo (o termo) exclusivamente firmado pelo compromitente e a CVM, para pleitear indenização complementar (o que pode ser feito existindo ou não o adimplemento da obrigação de indenizar pactuada no acordo - nos casos, por exemplo, em que a CVM entender adequada uma reparação de determinado valor, e o terceiro prejudicado entender ser merecedor de ressarcimento em valor superior) é necessária a proposição de ação ordinária, na qual deverá o autor provar a existência do ilícito, a quantificação do dano sofrido e a insuficiência da indenização recebida nos termos do acordo, para então pleitear a recomposição do seu patrimônio ${ }^{440}$.

Note-se que o pleito de complementação de indenização não é interessante para o sistema em exame, pois minimiza os efeitos benéficos do acordo administrativo, ao não

\footnotetext{
"Referido conceito não se restringe aos acusados, podendo incluir qualquer parte interessada na celebração do referido termo de compromisso". E vai além, afirmando que terceiros podem participar da assinatura do termo de compromisso: "É importante destacar que a referida possibilidade dos terceiros lesados participarem na celebração do termo de compromisso, não confere aos mesmos a condição de parte no processo administrativo, uma vez que a Deliberação CVM n. 390/2001 assim estabelece expressamente". Aparentemente, a autora fez uma leitura equivocada do artigo 10, parágrafo $1^{\circ}$, da D. CVM 390/01, ao interpretar que os terceiros consultados pela Comissão seriam parte do acordo administrativo que viesse a ser celebrado, mas não seriam parte no processo administrativo relacionado. Adotando-se uma interpretação sistemática da norma, pode-se perceber que nas outras seis vezes em que o termo "interessado" (e suas flexões) é utilizado na deliberação mencionada, a regra se refere exclusivamente aos investigados, proponentes do acordo.

438 EIZIRIK (1998, Reforma..., p. 103).

${ }^{439}$ Cumpre informar que o pagamento a terceiros deve ser efetuado diretamente pelo compromissário, sem intermediação da Comissão, como disciplina o parágrafo $2^{\circ}$ do artigo $5^{\circ}$ da D. CVM 390/01.

440 "Caso tenha sido acordado o pagamento de certa quantia como indenização, uma vez não satisfeita a obrigação [...] o terceiro prejudicado poderá ingressar com uma ação de execução, requerendo o valor que havia sido fixado. Saliente-se que o título executivo corresponde exatamente ao quantum determinado no acordo. Se desejar pleitear mais do que havia sido acordado, deverá o indenizado propor ação de procedimento ordinário, tendo que provar que foi cometido um ilícito, que o outrora indiciado ou acusado deu causa ao dano que sofreu, e que o valor que lhe foi oferecido como reparação é inferior ao seu prejuízo. Uma vez provados todos estes fatos, o juiz irá fixar o valor que deverá ser pago como diferença”. EIZIRIK, (1998, pp. 272-273).
} 
eliminar a necessidade de busca de ressarcimento perante o Poder Judiciário. Por tal motivo, já em 1998 a Procuradoria Juridica da $\mathrm{CVM}^{441}$ afirmava que

\begin{abstract}
"Dentro do espírito de conferir maior efetividade ao processo, eliminando de imediato os efeitos negativos de práticas inadequadas verificadas no mercado de capitais, é interessante que os eventuais prejudicados sejam satisfeitos integralmente em suas pretensões indenizatórias. Tal não ocorrendo, inviabilizada estará a total eliminação dos efeitos negativos deixados pelas infrações apuradas, impedindo que se atinja com plenitude o escopo do termo de compromisso".
\end{abstract}

Para que ocorra o melhor aproveitamento da ferramenta, a D. CVM 390/01 estabeleceu $^{442}$ que o Colegiado deverá considerar ${ }^{443}$, na apreciação da proposta de acordo, a manifestação de terceiros lesados, em relação à suficiência da indenização oferecida.

Outro mecanismo possível de ser adotado pelos compromitentes seria a obtenção de concordância expressa do terceiro indenizado (naturalmente, viável apenas nos casos de agentes já identificados) em relação ao valor atribuído, declarando-se satisfeito com o valor compromissado, procedimento pelo qual parece ser possível assegurar a inexistência de futuros pleitos ${ }^{444}$. Importante ressaltar que, considerando não

\footnotetext{
${ }^{441}$ Parecer/CVM/PJU/ 5 - 98.

${ }^{442}$ Artigo 10, parágrafo $2^{\circ}$.

${ }^{443}$ No extrato da ata de reunião do Colegiado de 19 de agosto de 2008 , em que se deliberou a recusa à proposta apresentada por parte dos acusados no Processo Administrativo Sancionador 14/2005, lê-se que: "O Comitê informou que, não obstante os esforços despendidos, não logrou êxito em sua tentativa de aproximação entre os proponentes e o [Acionista] (principal acionista minoritário da [Companhia]), visando à assunção de compromisso decorrente de um prévio ajuste entre eles, cujos termos poderiam, no entender do Comitê, servir como balizamento à recomposição, nesta via administrativa, também dos danos potencialmente experimentados pelos demais acionistas minoritários da Companhia. O Comitê observou, ainda, que a peça acusatória não quantifica em cifras exatas os prejuízos em apreço, o que, por seu turno, torna relativamente difícil a análise da proposta de Termo de Compromisso sob o ângulo do requisito legal da indenização. [...] Adicionalmente, o Comitê depreendeu que não se pode ignorar as alegações do [Acionista] acerca da continuidade da prática do ato considerado ilícito, de sorte que, diante de tal incerteza, não há como afirmar, no presente momento, o cumprimento do requisito inserto no inciso I do $\$ 5^{\circ}$ do art. 11 da Lei 6.385/76 (cessação da prática do ato)".
}

Trecho relevante do Parecer do Comitê de Termo de Compromisso datado de 5 de agosto de 2008, que fundamentou a decisão da Diretoria Colegiada, esclarece, referindo à regra ora comentada, que "[...] Nesse tocante, as informações prestadas pelo [Acionista] relativas à extensão dos danos que teriam sido por ele suportados na qualidade de principal acionista minoritário da [Companhia], bem como o valor da reparação, nos moldes do art. 10 da Deliberação CVM n 390/01, mostram-se importantes à instrução dos autos, por revelarem os anseios daquele que se vira prejudicado a partir das condutas irregulares imputadas aos proponentes. Contudo, sem adentrar nas minúcias do levantamento em tela, podemos verificar considerável disparidade entre o valor apresentado pelo Clube e aquele oferecido pelos proponentes no âmbito do Termo de Compromisso, o que, s.m.j., demonstra a dificuldade em se chegar a um consenso sobre a matéria".

${ }^{444}$ Digno de referência o termo de compromisso firmado em 31 de maio de 2006, no contexto do Processo Administrativo Sancionador CVM n. SP 2005/0339, no qual constou cláusula prevendo que "Os COMPROMITENTES se obrigam a pagar à investidora [Terceiro] a importância de $\mathrm{R} \$ 20.238,05$ (vinte mil duzentos e trinta e oito reais e cinco centavos), atualizada pelo IPCA e acrescida de juros de $12 \%$ ao ano até a data do pagamento, desde já aceita pela referida investidora como indenização plena pelas eventuais perdas experimentadas na operação [Operação]". A inclusão do terceiro na condição de anuente (e não de parte) é expediente (raríssimo, tendo sido o único encontrado em consulta ao banco de dados de termos de 
ser o terceiro parte do acordo, o Colegiado pode analisar a manifestação do prejudicado e, a par do seu teor, optar pela celebração do compromisso.

Cabe também rememorar observação feita no item anterior, de que pode ser feita a determinação e identificação dos terceiros prejudicados por ofícios, editais ou outras ferramentas para localização dos titulares do direito de ressarcimento, sem que, evidentemente, torne-se o notificado parte do acordo ou do procedimento sancionador ${ }^{445}$.

Por fim, interessante informar que, diferentemente do que ocorre nos acordos firmados para encerrar procedimentos administrativos sancionadores originados no mercado de valores mobiliários, no contexto concorrencial a Lei 12.529/11 ${ }^{446}$ prevê, como forma de potencializar a indenização de prejuízos, a admissão da intervenção de terceiros que possam ter direitos ou interesses afetados pela decisão da autoridade de celebrar um termo.

\subsubsection{Exame de legalidade pela Procuradoria Federal Especializada}

À Procuradoria Federal Especializada ("PFE”) cabe a análise da proposta de termo de compromisso, com o fim de chancelar o atendimento dos requisitos legais (incisos do parágrafo $5^{\circ}$ do artigo 11 da Lei 6.385/76 e inexistência de infração às regras a respeito da prevenção à lavagem de bens), sem qualquer juízo de adequação, conveniência ou oportunidade das obrigações sugeridas pelo administrado ${ }^{447}$.

compromisso disponibilizado no website da CVM) benéfico exclusivamente ao compromitente, pelo qual afasta novas tentativas de obtenção de indenização pelo prejudicado, embora a anuência ou não pouco interfira na validade ou eficácia do acordo substitutivo. Causa estranheza, porém, a manifestação do Colegiado, registrada na ata da reunião de 4 de abril de 2006, na qual "O Colegiado acompanhou o entendimento consubstanciado no parecer do Comitê, deliberando pela aceitação da proposta de celebração de Termo de Compromisso, tendo ressaltado que será condição para a comprovação de cumprimento do Termo de Compromisso a aceitação pela investidora da indenização proposta, que deverá ser atualizada até a data do efetivo pagamento [...]". Não parece ser adequado, considerando o regramento vigente, condicionar o cumprimento do termo de compromisso à concordância de terceiros alheios à relação processual existente quanto ao seu conteúdo.

445 “[...] de acordo com o art. 11 da Deliberação n. 390/01, a Comissão de Valores Mobiliários poderá, a sua escolha, notificar os investidores lesados ou publicar editais, no caso de número indeterminado de investidores prejudicados, para que prestem informações a respeito do montante que eventualmente lhes será pago, a título de reparação. Tal faculdade, no entanto, não tem o condão de erigir o investidor à condição de parte do procedimento administrativo sancionador na Comissão de Valores Mobiliário. (CARVALHOSA e EIZIRIK, 2002, p. 522).

${ }_{446}$ Artigo 85, parágrafo 15, combinado com o artigo 50.

${ }^{447}$ Sobre o tema, apresentação informal do trabalho desenvolvido pela PFE por uma de suas integrantes: “[...] a Advocacia Geral da União é que, por meio da Procuradoria Federal Especializada, atua no âmbito da autarquia, inclusive no termo de compromisso. Tem um 'check-list' da Procuradoria Federal, porque a Procuradoria Federal, dá uma opinião e olha os aspectos legais. Ela não entra no mérito administrativo, ela não fala para a autarquia se é conveniente ou oportuna aquela formulação. Mas a Procuradoria olha o quê? Se as pessoas estão qualificadas da devida maneira. Qual o teor da proposta, se é monetária, o que é? Se chegou a lesar, se alcançou interesses difusos ou coletivos, por exemplo. [...] E, sobretudo, se aquilo seria uma lavagem, se cairia na Instrução CVM 301 ou na Lei 9.603 (sic), porque, a, não tem como formular mesmo o 
Tal competência é fundamentada no artigo 11, V, da Lei Complementar n. 73, de 10 de fevereiro de 1993, combinado com artigo 10, parágrafo $1^{\circ}$, da Lei n. 10.480 , de 2 de julho de 2002, e apenas é reafirmada pelo parágrafo $5^{\circ}$ do artigo $7^{\circ}$ da D. CVM 390/01, conforme alterado pela D. CVM 486/05 448 .

Para análise do preenchimento das exigências essenciais, a Procuradoria Federal Especializada pode servir-se do apoio de outras áreas da Comissão, como no caso da análise da proposta apresentada no Processo Administrativo Sancionador de Rito Sumário CVM n. 2011/9488, em que a "PFE/CVM apreciou os aspectos legais da proposta de Termo de Compromisso, tendo concluído pela existência de óbice à celebração do ajuste, vez que, segundo informado pela área técnica, não teriam sido entregues todas as informações pendentes"

A conclusão da PFE é bastante relevante para o prosseguimento da análise do acordo, vez que celebrar acordo eivado de ilegalidade pode acarretar responsabilidade do agente da administração pública, além de comprometer a credibilidade do sistema dos termos de compromisso como um todo. Não por outro motivo, as observações da PFE usualmente são seguidas pelo Comitê de Termo de Compromisso, e pelo Colegiado ${ }^{450}$.

\subsubsection{Análise pelo Comitê de Termo de Compromisso}

O Comitê de Termo de Compromisso ${ }^{451}$ tem a tarefa determinada pela D. CVM 390/01, conforme modificada pela D. CVM 486/05, de apresentar parecer a respeito da oportunidade e conveniência na celebração de termo de compromisso em cada proposta encaminhada pelos administrados. Também deve o Comitê se manifestar em relação à adequação das obrigações sugeridas pelos acusados para celebração do termo, já considerando os elementos que devem ser analisados pelo Colegiado em sua decisão de

termo de compromisso, por impeditivo legal. Agora, a Procuradoria analisa e remete para esse comitê, que vai fazer julgamento." Declaração da Dra. Ilene Patrícia de Noronha Najjarian, registrada na p. 43 do v. 7 , n. 6, dos Cadernos Direito GV, Seminário 38, v. 7, n. 6, nov. 2010.

448 Pela redação original, cabia à extinta Procuradoria Jurídica da CVM opiniar sobre a legalidade da proposta.

${ }^{449}$ Parecer do Comitê de Termo de Compromisso datado de 11 de janeiro de 2012, apresentado na apreciação de proposta no contexto do procedimento referido.

${ }^{450}$ Como no caso ora examinado, em que "Dessa forma, em linha com a manifestação da PFE/CVM, o Comitê concluiu pela existência de óbice legal à aceitação da proposta apresentada, pelo não atendimento aos requisitos legais necessários à celebração do Termo de Compromisso (cessação da prática do ato ilícito e correção das irregularidades detectadas)". Em seguida, em reunião de 23 de fevereiro de 2012, “O Colegiado, acompanhando o entendimento exarado no parecer do Comitê de Termo de Compromisso, deliberou a rejeição da proposta de termo de compromisso apresentada pelo [Acusado]".

${ }^{451}$ No presente item será tratada apenas da função do Comitê de Termo de Compromisso, conforme estabelecida na D. CVM 390/01, como atualizada. Para informações a respeito de sua origem, regramento, composição, entre outros temas, ver item 10.1.1 infra. 
aceitar ou recusar as propostas de acordo, em seu juízo de conveniência e oportunidade (natureza e gravidade das infrações sob análise, antecedentes do acusado e efetiva possibilidade de punição) $)^{452}$.

A redação atual dos parágrafos do artigo $8^{\circ}$ da D. CVM 390/01 estabelece um cronograma de atuação do Comitê, garantindo a agilidade necessária na condução de suas funções. Após o recebimento da análise de legalidade empreendida pela PFE (a qual não costuma ser muito demorada, considerando sua natureza), o órgão tem 30 (trinta) dias para apresentar seu parecer.

Tal prazo pode ter seu termo inicial retardado em até 60 (sessenta) dias, caso o Comitê entenda ser proveitoso empreender negociação com o proponente, em relação ao conteúdo da proposta apresentada, com o escopo de moldá-la de forma a torná-la satisfatória, no entender do próprio Comitê. É habitual a utilização do período de negociações entre o Comitê e o interessado ${ }^{453}$, sendo frequente o agendamento de reuniões ${ }^{454}$, troca de correspondências eletrônicas ${ }^{455}$ e contato entre os membros do Comitê e representantes dos proponentes.

Assim, entre o recebimento do posicionamento da PFE e a apresentação do parecer pelo Comitê, finalmente habilitando a proposta de termo de compromisso para submissão à deliberação pelo Colegiado, é possível que transcorram até 90 (noventa) dias.

O trabalho do Comitê, em linhas gerais, consiste em (i) verificar a conveniência e oportunidade na aceitação de termo de compromisso no caso apresentado, e (ii) nos casos em que lhe parecer adequado, indicar a celebração de acordo administrativo,

\footnotetext{
${ }^{452}$ Artigo $8^{\circ}$ da D. CVM 390/01, conforme alterada pela D. CVM 486/05.

${ }^{453} \mathrm{O}$ qual é informado da decisão do Comitê de abrir negociações mediante o envio de um "Comunicado de Negociação", e deve apresentar manifestação sobre a adesão ou não à contraproposta. Referência aos comunicados de negociação são apresentados em diversos pareceres do Comitê de Termo de Compromisso, incluindo, v.g., o documento datado de 11 de julho de 2012, no contexto do Processo Administrativo Sancionador CVM n. RJ 2012/01542.

${ }^{454}$ Exemplifique-se com a negociação para celebração de termo de compromisso no âmbito do Processo Administrativo Sancionador CVM n. RJ2012/3785. Em tal caso, em reunião mantida com o Comitê, o órgão sugeriu a majoração de proposta original, a qual consistia em pagamento de $\mathrm{R} \$ 50.000,00$ (cinquenta mil reais) à $\mathrm{CVM}$, para pagamento de $\mathrm{R} \$ 200.000,00$ (duzentos mil reais) à autarquia. Ainda na própria reunião, "[...] tendo o representante legal do proponente anuído com a contraproposta do Comitê", foi finalizada a negociação, de modo concomitante à finalização do parecer. (Parecer do Comitê de Termo de Compromisso datado de 13 de junho de 2012).

455 Durante a negociação de proposta de termo de compromisso no contexto do Processo Administrativo Sancionador CVM n. RJ2011/3823, a negociação das condições a serem propostas por um dos acusados foram confirmadas ao Comitê via correio eletrônico: "consoante negociação realizada na forma do item 25 deste parecer, o proponente aderiu ao valor de $\mathrm{R} \$ 47.000,00$ (quarenta e sete mil reais) sugerido pelo Comitê, por meio de correspondência eletrônica encaminhada tempestivamente em 23.03.12". (Parecer do Comitê de Termo de Compromisso datado de 16 de maio de 2012).
} 
estipular um patamar ${ }^{456}$ no qual pareça aceitável o acordo, além de negociar com o proponente, objetivando aproximar a proposta do parâmetro estabelecido. Sua tarefa, então, independe da análise de questões próprias do julgamento, incluindo a solidez das provas de materialidade e autoria:

\begin{abstract}
"Assim, na análise da proposta de celebração de Termo de Compromisso há que se verificar não somente o atendimento aos requisitos mínimos estabelecidos em lei, como também a conveniência e oportunidade na solução consensual do processo administrativo. Para tanto, o Comitê apoia-se na realidade fática manifestada nos autos e nos termos da acusação, não adentrando em argumentos de defesa, à medida que o seu eventual acolhimento somente pode ser objeto de julgamento final pelo Colegiado desta Autarquia, sob pena de convolar-se o instituto em verdadeiro julgamento antecipado. Ademais, agir diferentemente caracterizaria, decerto, uma extrapolação dos estritos limites da competência deste Comitê, ${ }^{457}$.
\end{abstract}

\title{
9.2.4.1. Negociação do termo de compromisso
}

A negociação das condições do termo de compromisso tem o escopo de sinalizar ao proponente qual a expectativa da Comissão em relação às condições que entende serem suficientes para a aceitação de um acordo, considerando aquilo que, no caso concreto, se mostre como coerente com a salvaguarda do interesse público ${ }^{458}$. Verdade que tal negociação é conduzida por um órgão técnico e operacional, e o entendimento aí produzido não vincula a decisão do corpo diretivo da autarquia. Mas, ainda assim, trata-se de um bom indicativo.

O procedimento de negociação foi formalizado pela D. CVM 486/05, que alterou a D. CVM 390/01 ao criar o Comitê que conduz tal procedimento. Anteriormente,

\footnotetext{
${ }^{456}$ Sobre o tema, explicativa declaração do Dr. Eli Loria, registrada na p. 37 do v. 7, n. 6, dos Cadernos Direito GV, Seminário 38, v. 7, n. 6, nov. 2010 “[não existem critérios objetivos definidos] Mas nós percebemos que nos últimos casos houve um balizamento, dependendo do caso, da gravidade. Isso não entra no mérito da acusação, ele não entra no mérito se está certo ou está errado. Eles vêem aquela acusação e, para eles, aquilo é a verdade. Não entram no mérito da defesa. A defesa fica para o julgamento. Então, dependendo da gravidade da acusação, eles têm as balizas deles e estão subindo gradativamente a régua, por conta do desestimulo das condutas semelhantes. O mercado também sabe quanto custa, ele faz a conta. Então, se eu não publicar um fato relevante, eu pago $50 \mathrm{mil}$, eu economizao 50 mil do jornal e está tudo certo, não é? Então, isso aí, vai subindo aos poucos, o aprendizado".

${ }^{457}$ Explicação divulgada no Parecer do Comitê de Termo de Compromisso, datado de 25 de abril de 2012, a respeito da proposta de termo de compromisso apresentada pelos acusados no Processo Administrativo Sancionador CVM nº 17/2006.

458 “A transação pressupõe a existência de um espaço de conformação que a lei outorga ao administrador (em outras palavras, discricionariedade) para valorar, no caso concreto, as medidas necessárias para a proteção do interesse público. Transacionar não importa abrir mão do interesse público. A transação existe para permitir a concretização do interesse público, sem excluir a participação dos particulares interessados na solução da contenda". BACELLAR FILHO (2007, p. 193).
} 
as negociações com os proponentes eram conduzidas pelos Diretores ${ }^{459}$ encarregados de relatar os procedimentos sancionadores ${ }^{460}$.

A dinâmica da negociação dos termos usualmente envolve a apresentação, pelo Comitê, do objetivo do termo de compromisso, e considerações a respeito das condições que, no seu entender, devem ser objeto de adequada adaptação, para ser satisfeita tal finalidade ${ }^{461}$.

Também é comum seguir o Comitê com a fundamentação a respeito da definição dos parâmetros, ainda que de forma genérica, apontando precedentes assemelhados, na medida do possível, e consignando que sua análise se fundamenta

${ }^{459}$ Exemplo célebre é o caso da negociação capitaneada pelo Diretor Pedro Marcilio de Sousa de termo de compromisso no Processo Administrativo Sancionador RJ n. 2006/6235, concluída poucos dias antes da data prevista para o julgamento administrativo, a qual assegurou ressarcimento de aproximadamente $\mathrm{R} \$ 28.000 .000,00$ (vinte e oito milhões de reais) a correntistas de instituição financeira.

${ }^{460}$ Certa vez, uma sociedade investigada apresentou, em pedido de reconsideração de decisão que rejeitou a proposta de termo de compromisso apresentada para suspensão do Processo Administrativo Sancionador de Rito Sumário CVM n. RJ 2003/3648, em período coincidente com a audiência pública que precedeu a norma responsável pela criação do Comitê de Termo de Compromisso e formalização dos procedimentos de negociação, os seguintes argumentos: "a minuta de Termo de Compromisso decorre da negociação entre as partes envolvidas, até porque é pouco provável que a proposta inicial contemple todos os pontos tidos como essenciais ou adequados pela CVM; no caso, a rejeição liminar da proposta, sem a possibilidade de negociação ou alteração, reconhecida no Edital de Audiência Pública que visa alterar a Deliberação CVM N 390 , foi prejudicial à [Acusada] e ao próprio espírito dos normativos vigentes; a previsão de criação de comitê para negociar as condições apresentadas pelos proponentes é um dos pilares da nova Deliberação e permite a discussão ampla a respeito, o que não se fez presente neste processo", e pleitearam, "por questão de justiça e respeito à intenção do legislador, seja concedido tratamento idêntico ao que se pretende dar a todos os acusados em processos sancionadores, com a abertura de negociação, e reconsiderada a decisão, ou o encaminhamento do presente recurso à apreciação do Conselho de Recursos do Sistema Financeiro Nacional - CRSFN". A Diretora, então apresentou voto explicando, preliminarmente, que "desta decisão não é admitido recurso ao CRSFN" para, em seguida, reconhecer que "de fato, embora não esteja prevista expressamente na atual regra a possibilidade de negociação com os interessados, como constou do Edital de Audiência Pública que visa estabelecer novas regras a respeito do assunto, esse procedimento na prática sempre existiu e dependia muito da iniciativa dos interessados". No caso concreto, "a proposta foi apresentada como definitiva e não houve qualquer tentativa ou mesmo contato no sentido de aprimorá-la", mas, ainda "assim, apesar de ainda não haver previsão a respeito, não vejo nenhuma inconveniência a que se reabra o prazo à interessada para que apresente uma nova proposta de Termo de Compromisso", com o que decidiu a concessão de prazo de 30 dias à requerente, para apresentação de nova proposta de acordo substitutivo (todos os trechos citados foram extraídos do relatório e voto da Diretora Norma Parente, datado de 9 de agosto de 2005).

${ }^{461}$ Exemplo extraído do procedimento descrito no Parecer do Comitê de Termo de Compromisso, proferido em 11 de julho de 2012, a respeito de proposta formulada pelo acusado no Processo Administrativo Sancionador de Rito Sumário CVM n. RJ 2011/7948: “[...] a juízo do Comitê, a proposta merece ser aperfeiçoada para a melhor adequação a esse tipo de solução consensual do processo administrativo, considerando orientação do Colegiado no sentido de que as propostas de Termo de Compromisso devem contemplar obrigação que venha a surtir importante e visível efeito paradigmático junto aos participantes do mercado de valores mobiliários, inibindo a prática de condutas assemelhadas. Diante das características que permeiam o caso concreto e em linha com as decisões do Comitê em precedentes mais recentes com comparáveis características essenciais, o Comitê sugere o aprimoramento da proposta a partir da majoração do valor ofertado para $\mathrm{R} \$ 50.000,00$ (cinquenta mil reais)". 
exclusivamente pelas informações registradas na peça acusatória, sem análise de argumentos de defesa ${ }^{462}$.

Cabe aqui uma nota intercorrente. Ao não verificar os argumentos da defesa do acusado, o Comitê certamente ganha agilidade em sua avaliação (ponto amplamente positivo, considerando o longo prazo que tem para concluir sua tarefa). Porém, deixa de satisfazer um critério estabelecido pelo artigo $8^{\circ}$, combinado com o artigo $9^{\circ}$, da D. CVM 390/01: consideração da "efetiva possibilidade de punição, no caso concreto".

Após a conclusão da exposição das ideias pelo Comitê, é concedido prazo ${ }^{463}$ para o proponente comentar tais questões e, se entender apropriado, apresentar emenda à proposta anteriormente submetida ${ }^{464}$, com o que terá o órgão elementos suficientes para redigir o parecer, propondo à Diretoria Colegiada a aceitação ou rejeição da proposta de acordo apresentada.

Uma vez finalizado, o parecer é encaminhado ao Colegiado, que é livre para observá-lo ou não, cabendo à Diretoria fazer o exame de adequação da proposta.

Decorre da possibilidade de negociação, além das vantagens acima tratadas, também um problema, ilustrado com os casos a seguir narrados.

Veja-se, por exemplo, o caso de um administrador, inegavelmente conhecedor das normas aplicáveis ao mercado de valores mobiliários brasileiro (bacharel, mestre e doutor em direito em renomadas instituições de ensino nacionais e estrangeiras, com especialização em direito comercial) que, em intervalo inferior a seis meses, vê serem instaurados contra si dois procedimentos administrativos sancionadores distintos, um para

\footnotetext{
${ }^{462}$ Excerto extraído do mesmo parecer: “[...] Vale destacar que, consoante entendimento já consubstanciado em sede de Termo de Compromisso, a análise do Comitê é sempre pautada pela realidade fática manifestada nos autos e os termos da acusação, não competindo neste momento processual adentrar em argumentos próprios de defesa, à medida que o seu eventual acolhimento somente pode ser objeto de julgamento final pela área técnica e pelo Colegiado desta Autarquia, sob pena de convolar-se o instituto do Termo de Compromisso em verdadeiro julgamento antecipado. Ademais, não é demasiado lembrar que a celebração do ajuste a que se refere não importa confissão quanto à matéria de fato, nem reconhecimento de ilicitude da conduta analisada (art. $11, \S 6^{\circ}$ da Lei $\left.n^{\circ} 6.385 / 76\right)$ ".

${ }^{463}$ Excerto extraído do mesmo parecer: "Isto posto, o Comitê assinala o prazo de 10 (dez) dias úteis para que o proponente apresente suas considerações e corrija as irregularidades apontadas pela SEP no âmbito desse processo, e conforme o caso, adite a proposta apresentada, ocasião em que será encerrada a fase de negociação de que trata o $\S^{\circ}$ do art. $8^{\circ}$ da Deliberação $C V M n^{\circ} 390 / 01$, com o conseqüente encaminhamento de parecer ao Colegiado".

${ }^{464}$ A proposta de termo de compromisso apresentada no âmbito do Processo Administrativo Sancionador CVM N. RJ 2011/7923 observou a seguinte dinâmica de negociação, conforme relatado no Parecer do Comitê de Termo de Compromisso, datado de 17 de outubro de 2012: (i) proposição original, de pagamento de $\mathrm{R} \$ 500.000,00$ (quinhentos mil reais); (ii) sugestão de aprimoramento do Comitê, majorando para $\mathrm{R} \$ 10.000 .000,00$ (dez milhões de reais); (iii) reunião entre representantes do acusado e o Comitê; (iv) apresentação de nova proposta pelo acusado, no valor de $\mathrm{R} \$ 3.000 .000,00$ (três milhões de reais); (v) sugestão de aprimoramento do Comitê, majorando para $\mathrm{R} \$ 5.000 .000,00$ (cinco milhões de reais); e (vi) adesão do proponente à recomendação do Comitê. Tal proposta foi aprovada pela Diretoria Colegiada, em 11 de dezembro de 2012.
} 
apurar conduta de utilização de informação privilegiada para negociação com BDRs ${ }^{465}$ e o segundo para apurar a não divulgação de fato relevante, sendo ele o responsável por tal tarefa.

Em ambos os casos, o administrador manifesta interesse em celebrar termo de compromisso, apresenta proposta de valor bastante reduzido (não apenas em comparação com termos tratando das mesmas potenciais infrações, mas também em valores absolutos), sendo nos dois casos sugerido pelo Comitê de Termo de Compromisso que majore sua proposta.

O acusado, dentro do prazo regulamentar, faz novas propostas, correspondendo a $50 \%$ do valor indicado pelo Comitê, em um caso, e pouco mais de $25 \%$ do valor indicado, no outro. Ambas as propostas chegam à apreciação do Colegiado e são recusadas, sendo sorteado um relator para o processo. Transcorrido novo intervalo de tempo, avizinhando-se o julgamento, o interessado reabre as negociações, faz nova proposta, sem que seja atendido o pleiteado anteriormente pelo Comitê. O Comitê replica seu posicionamento anterior, com o valor originariamente entendido como adequado, finalmente obtendo a adesão do administrado a tal contraproposta. A nova minuta é submetida à Diretoria Colegiada e aceita, com o quê ocorre a suspensão do processo sancionador.

A repetição de exatamente todos os mesmos passos, quais foram (i) manifestação de interesse em celebrar acordo, (ii) oferecimento de proposta irrisória, (iii) abertura de negociação com o Comitê de Termos de Compromisso, (iv) majoração da proposta, de forma moderada e aquém do sugerido pelo Comitê, (v) submissão ao Colegiado, (vi) rejeição da proposta e designação de relator para julgamento, (vii) nova apresentação de proposta, insatisfatória, (viii) reabertura das negociações, (ix) adesão do proponente às condições sugeridas pelo Comitê, nos exatos termos do indicado na negociação original, $(x)$ adesão à proposta do Comitê, (viii) aceitação ${ }^{466}$ e assinatura do termo de compromisso, com diferença de poucos meses entre a ocorrência de cada um dos eventos, em um processo administrativo sancionador e em outro, evidencia estratégia

\footnotetext{
${ }^{465}$ Certificados de depósito de valores mobiliários com lastro em valores mobiliários de emissão de companhias com sede no exterior.

${ }^{466}$ A única diferença entre as duas decisões é que o Diretor Eli Loria, relator do primeiro caso (Processo Administrativo Sancionador CVM RJ2009/8286), cuja segunda proposta submetida ao Colegiado foi aprovada por unanimidade, manifestou-se contrário à aceitação da proposta aceita no âmbito do segundo caso (Processo Administrativo Sancionador RJ2010/0770), por entender tal aceitação ser inoportuna e inconveniente. Registre-se também que houve a modificação da composição do Colegiado, entre a análise das duas propostas, com substituição do Diretor Marcos Barbosa Pinto pela Diretora Luciana Pires Dias.
} 
uniforme, a qual consistiu em expediente evidentemente protelatório conduzido pelo (ab)uso do termo de compromisso, em ambos os casos.

O particular, compreendendo a lógica da CVM e aproveitando-se da possibilidade de aditamento das propostas e da formatação (adequada, diga-se de passagem) consistente na negociação com o órgão técnico e apresentação de propostas ao Colegiado, obteve o benefício temporal a seu favor. Considerando o interesse do agente em auferir os benefícios garantidos pelo Termo de Compromisso ${ }^{467}$, caso tivesse consciência de que não seria provável a aceitação de uma proposta, em momento futuro, pelo exato valor indicado pelo Comitê inicialmente, provavelmente proporia ao Colegiado, na primeira oportunidade, o valor que se dispôs a pagar após nova rodada de negociações (evitando-se conduta que acarretou mobilização do órgão técnico avaliador das propostas, da Diretoria Colegiada e dos servidores que dedicaram horas de trabalho na instrução e preparação para julgamento).

Assim, embora o comportamento do administrador-compromitente, acima narrado, possa ser reprovável, não configura qualquer ilegalidade, pois agiu em estrita observância aos procedimentos vigentes e aplicáveis. No entanto, pode ser criticada a atuação da Diretoria Colegiada da CVM, em casos como esse. Ainda que os valores oferecidos como compromisso se assemelhem ou superem as multas previstas na Lei 6.385/76, talvez seja o caso de, existindo provas suficientes, julgar e condenar tais investigados para, inclusive, em caso de reincidência (evitada com a sucessiva assinatura de termos de compromisso), os acusados serem punidos com penas restritivas de direitos, que parecem surtir mais efeito, no cenário atual, em que seguros de responsabilidade civil de administradores (chamados seguros ${\mathrm{D} \& \mathrm{O}^{468}}^{4}$ ) inclusive arcam com os valores pagos à CVM como condição para celebração de termos de compromisso ${ }^{469}$.

\footnotetext{
${ }^{467}$ Foi registrado ainda mais um caso, pendente de julgamento, no qual o mesmo agente é acusado de negociação de BDRs enquanto detentor de informação relevante ainda não divulgada, no qual foi recusada proposta de pagamento no valor de $\mathrm{R} \$ 631.120,00$ (seiscentos e trinta e um mil, cento e vinte reais), fundamentalmente porque nem todos os acusados propuseram a celebração de termo de comproimisso. A recusa do acordo ocorreu menos de um ano após o cumprimento do termo de compromisso celebrado no caso anterior, com o que é possível concluir que o propósito inibidor de condutas e de orientação das práticas não produziu os efeitos esperados.

${ }^{468}$ Termo derivado da expressão directors and officers liability insurance.

469 Tal seguro, que "tem por objeto o pagamento pela seguradora dos valores despendidos pelos administradores de sociedades e de entidades sem fins lucrativos em decorrência de reclamações relativas a atos de gestão praticados pelos administradores no exercício de suas atribuições" (FARIA, 2011, pp. 65-66), foi criado pelo Lloyd's of London para o mercado estado-unidense após crise de 1929 e chegou ao Brasil nos pacotes de benefícios dos executivos expatriados na década de 1990, após as privatizações. A utilização de tais seguros intensificou-se, em "decorrência da crise financeira mundial ocorrida no final de 2008, que causou uma maior percepção pelas empresas quanto aos riscos a que estão expostas, e pelos executivos quanto à possibilidade de serem responsabilizados por seus atos de gestão, como ocorreu com a Aracruz
} 
Celulose S.A. e a Sadia S.A., que ingressaram com ações de responsabilidade contra ex-diretores". (FARIA, 2011, p. 68). Deve ser registrado que a cobertura securitária é contratada pela companhia, responsável pelo pagamento do prêmio, em benefício de seus administradores. A respeito do funcionamento e sua interação com os termos de compromisso, cumpre registrar que a seguradora indeniza "diretamente o administrador pelos valores que ele tenha despendido com custos de defesa ou condenações pecuniárias, relativos a eventos cobertos pelo seguro e desde que tais valores não tenham sido previamente pagos ao administrador pela empresa tomadora" (FARIA, 2011, p.74), e que, exceto disposto em sentido contrário na apólice contratada, para que haja cobertura quanto ao evento "celebração de termo de compromisso", é necessária a concordância seguradora com os termos de tal acordo. Outra peculiaridade decorrente do acionamento dos seguros para sinistros relacionados a termos de compromisso firmados com a CVM diz respeito à exclusão de cobertura: atos fraudulentos ou dolosos são expressamente excluídos. Para operar tal exclusão, a seguradora depende da existência de declaração de dolo ou fraude manifestada pelo julgador dos casos, pois a seguradora não tem legitimidade para avaliar as condutas e negar a cobertura. Naturalmente, não há comprovação de dolo ou fraude do administrador segurado, nos casos de celebração de termos de compromisso.

O pagamento à CVM de valores compromissados com utilização de recursos de seguradoras não é recente: ao apresentar proposta para celebração de termo de compromisso no âmbito do Processo Administrativo Sancionador 05/2006, dois administradores "solicitaram que fosse concedido o prazo de 20 dias para a realização do pagamento da quantia acordada, visto que o pagamento à CVM será realizado com recursos provenientes de seguro de responsabilidade civil de administradores de empresa (D\&O), contratado pelas Companhias para casos como o presente" (conforme ata da Reunião do Colegiado de 8 de julho de 2008, que aprovou o acordo). Já na Reunião de 11 de novembro de 2008, na apreciação do cumprimento dos compromissos assumidos, "O Superintendente Geral esclareceu que os pagamentos previstos no Termo de Compromisso foram efetuados diretamente pela [Companhia] e [Companhia] - companhias nas quais os compromitentes eram administradores à época dos fatos objeto do presente processo -, tendo em vista que, segundo ajustado, o pagamento seria feito com recursos provenientes de seguro de responsabilidade civil de administradores".

A respeito da responsabilidade pelo pagamento dos valores à CVM, cumpre referir que, exceto nos casos de seguro, os pagamentos devem ser feitos sempre pelo compromitente. Caso o compromitente seja pessoa natural (administrador, por exemplo), a companhia para a qual trabalha não pode arcar com os valores devidos (exemplificativamente, no termo celebrado para suspender o Processo Administrativo Sancionador n. RJ 2007/10966, a Superintendência Administrativo-Financeira, responsável por atestar o cumprimento do pactuado, informou que o pagamento foi realizado pela sociedade administrada pelo compromitente, circunstância em que o Colegiado não determinou o arquivamento, mas sim o questionamento ao compromitente a respeito, e determinando que somente seria considerado cumprido o acordo com prova de ressarcimento do administrado à companhia, com o que se confirmou o adimplemento e o arquivamento do caso). Já em avaliação da proposta apresentada em relação ao Processo Administrativo Sancionador n. 2011/9488, o Comitê de Termo de Compromisso indicou como um dos motivos para parecer negativo o fato de não ser evidenciado se "o compromisso ora proposto pelo DRI seria de sua exclusiva responsabilidade, isto é, sem quaisquer ônus para a [Companhia], companhia aberta da qual é administrador" e cujo objeto é relacionado à obrigação de fazer proposta (parecer de 11 de janeiro de 2012, com o qual o Colegiado concordou em 23 de fevereiro de 2012).

Em outro caso (proposta oferecida em relação ao Processo Administrativo Sancionador CVM n. RJ 2009/8316), os administradores de companhia investigados propuseram pagamento de quantia à CVM, condicionada ao implemento de uma entre duas condições: “(i) seu integral pagamento pela [Seguradora], nos termos do Contrato de Seguro D\&O celebrado; ou (ii) caso a Seguradora não efetue o pagamento por considerar que não estejam atendidos os requisitos para a cobertura da hipótese vertente, que essa concorde com o entendimento de que a [Companhia], nos termos dos Contratos de Indenidade celebrados pela Companhia com cada um de seus administradores em 27.10.06 (anexados aos autos), pode efetuar o pagamento desses valores". O Comitê então, afirmou que o parecer em relação à proposta era positivo, desde que não fosse condicionada a qualquer evento. Alertou também que o pagamento não poderia ser feito pela Companhia, pois os compromitentes eram seus administradores. Por fim, registrou que "Sobre os contratos de seguro, especificamente, o Comitê compreende que se trata de uma relação contratual dos proponentes com terceiros na esfera civil, esfera essa que não se encontra sob jurisdição da CVM. Tais contratos de seguro têm sido considerados válidos para o cumprimento de obrigação pecuniária em Termo de Compromisso, mas a celebração do acordo em si não deve ficar condicionada a eles em hipótese alguma". A proposta de acordo, submetida ao Colegiado, foi aceita por maioria, "desde que o pagamento proposto não seja condicionado à implementação de nenhum evento e tampouco suportado pela Companhia, acompanhando o entendimento consubstanciado no parecer do Comitê". Tal decisão foi motivadora de 
Além da crítica, é possível apresentar duas alternativas para fazer cessar tal tipo de comportamento: (a) cada administrado poder apresentar uma única proposta à Diretoria Colegiada $^{470}$, exceto nos casos em que haja modificação da situação de fato em relação à proposta anterior ${ }^{471}$, avaliada de forma rígida; e (b) a cada proposta recusada, em decorrência do tempo transcorrido entre as reapresentações de sugestões de acordo, o valor entendido como adequado pelo Colegiado seja majorado (ou, sendo outro tipo de obrigação, ser incrementada) ${ }^{472}$

Exatamente a possibilidade de nova proposta ao Colegiado, fora do prazo ordinário, sem que possibilite indenização substancial aos lesados ou modificação de fato existente em relação à anterior, oferece um risco à estabilidade e à própria "reputação" do instituto do termo de compromisso como ferramenta de enforcement. No momento em que os agentes do mercado de valores mobiliários - evidentemente racionais e movidos por interesses econômicos - perceberem ser possível a apresentação de uma primeira proposta cujo compromisso ofertado é inferior ao máximo que estão dispostos a renunciar para a obtenção das vantagens decorrentes do acordo, por considerarem a possibilidade da existência de oportunidades adicionais de oferecimento de propostas, aditadas e aprimoradas em relação à anterior, a fim de obtenção da aceitação pela Diretoria Colegiada da CVM, parte das vantagens auferidas pelo órgão regulador ${ }^{473}$ serão reduzidas ou

pedido de reconsideração, na qual o Diretor Otavio Yazbek apontou as diferenças estruturais entre os acordos de indenidade e os seguros de responsabilidade dos administradores, ressaltando o papel da seguradora como "terceiro independente, com interesses distintos daqueles dos administradores da companhia", o que "reduz em muito a situação de conflito, o que justifica que se aceitem termos de compromisso que envolvam o pagamento por sociedades seguradoras". (Voto apresentado pelo Diretor Otavio Yazbek em 19 de janeiro de 2011, no pedido de reconsideração em relação à decisão do Colegiado sobre proposta de termo de compromisso apresentada no Processo Administrativo Sancionador 2009/8316).

${ }^{470}$ Com adoção do exemplo do direito concorrencial, em que cada investigado pode apresentar apenas uma proposta, e inexiste reconsideração ou apresentação de outras propostas.

${ }^{471}$ Requisitos análogos aos previstos anteriormente na D. CVM 486/05, em excerto revogado pela D. CVM $657 / 11$.

${ }^{472}$ Adaptando-se, de alguma forma, a racionalidade do "Discount for early settlement", previsto no item 6.7 do Decision Procedure and Penalties Manual (DEPP) da Financial Services Authority ("FSA") [disponível para consulta em <http://fsahandbook.info/FSA/html/handbook/DEPP/6/7>] - entidade regulatória nãogovernamental (embora tenha seus conselheiros apontados pelo Tesouro) criada pelo Financial Services and Markets Act 2000 do Reino Unido. Pelo mecanismo citado, um acordo celebrado mais cedo (i.e., com menor intervalo entre a infração e o acordo) garantirá ao agente econômico um desconto maior sobre a pena, seja ela financeira ou de suspensão ou restrição ao desempenho de atividades. O desconto não se aplica ao perdimento de lucros auferidos ou perdas evitadas em razão de operações irregulares, inegociável. O desconto a ser concedido sobre a penalidade varia em 4 estágios, sendo de $30 \%, 20 \%, 10 \%$ ou $0 \%$, a depender do momento processual em que se encontre, e a lógica do mecanismo consiste no reconhecimento (expresso no item 6.7.1 do normativo citado) de benefício mútuos por tais acordos, de recomposição ou proteção mais veloz de terceiros prejudicados, e economia de recursos do agente e da FSA na discussão das penalidades cabíveis.

${ }^{473}$ Abordadas no item 3.5.1. 
eliminadas. Seria reduzida, assim, de forma relevante a justificativa - sob o ponto de vista estatal - para a celebração de termos de compromisso com os administrados.

Situação assemelhada ocorreu no Processo Administrativo Sancionador RJ 2011/7948, instaurado para apurar responsabilidade do diretor de relações com investidores de companhia, acusado de inadimplência na apresentação de diversas informações obrigatórias. Intimado em julho de 2011, o acusado apresentou uma primeira proposta de termo em agosto de 2011 , oferecendo o pagamento de $\mathrm{R} \$ 10.000,00$, bem como a apresentação das informações em atraso (simples atendimento do requisito legal, que não representa compromisso real). O Comitê de Termo de Compromisso, em reunião realizada em novembro de 2011, sugeriu a majoração do valor oferecido, indicando $\mathrm{R} \$ 50.000,00$ como um valor compatível com o caso concreto e os "precedentes mais recentes com comparáveis características essenciais" $" 744$ e, em seguida, "diante de recente orientação do Colegiado desta autarquia referente aos processos de rito sumário dessa natureza"475, sugeriu novo valor $(\mathrm{R} \$ 35.000,00)$. No momento seguinte (já em meados de dezembro de 2011), o acusado apresentou nova proposta, incrementando em $\mathrm{R} \$ 2.000,00 \mathrm{a}$ anterior, e solicitando o parcelamento em duas prestações.

Em janeiro de 2012 o Comitê firmou parecer contrário à aprovação da proposta submetida, e o Colegiado, no final de fevereiro, seguiu a linha do Comitê, rejeitando a oferta do acusado. Ao ser cientificado da decisão da Diretoria Colegiada da Comissão (abril de 2012), o acusado apresentou nova proposta, com o pagamento de $\mathrm{R} \$ 30.000,00$, em duas parcelas, sucedida por nova decisão do Comitê no sentido de negociar os termos, para majoração do valor, nos exatos termos e condições do comunicado ainda em dezembro de 2011.

Finalmente, em junho de 2012 o acusado aditou a proposta, conforme sugerido pelo Comitê ainda no ano anterior, e no mês seguinte foi firmado parecer aprovando a nova proposta de acordo administrativo. Finalmente, na reunião da Diretoria Colegiada da CVM realizada em 24 de julho de 2012, o termo de compromisso foi aprovado, sendo (como de hábito) concedido prazo de 30 (trinta) dias para a assinatura do instrumento formalizador do acordo, contados da cientificação da decisão de aceitação da proposta, e 10 (dez) dias para pagamento do valor pactuado, contados da publicação do teor do documento no

\footnotetext{
${ }^{474}$ Parecer do Comitê de Termo de Compromisso a respeito de proposta apresentada no âmbito do Processo Administrativo Sancionador CVM RJ 2011/7948, datado de 11 de julho de 2012.

${ }^{475}$ Parecer do Comitê de Termo de Compromisso a respeito de proposta apresentada no âmbito do Processo Administrativo Sancionador CVM RJ 2011/7948, datado de 11 de julho de 2012.
} 
Diário Oficial da União. O prazo total, que nesse caso superou 12 (doze) meses, parece demasiado e prejudicial à efetividade dos acordos.

Mesmo quando inexiste delongada negociação (com a apresentação de uma série de propostas, ao Comitê de Termo de Compromisso e mesmo à Diretoria da CVM) é possível inferir, por consulta ao banco de dados disponibilizado pela $\mathrm{CVM}^{476}$, não serem raros os casos em que a publicação do termo na imprensa oficial demora 3 (RJ 2012/3785, RJ 2012/10840), 5 (RJ 2011/7386) ou até 8 meses (RJ 2010/4524, cuja proposta aprovada em 13 de setembro de 2011 e publicada em 30 de maio de 2012 fora uma segunda proposta, considerando a rejeição, em 30 de novembro de 2010, de uma proposta anterior) após a aprovação da proposta pelo Colegiado, atrasando o vencimento do compromisso e esvaziando a sua função primordial, de garantir resposta rápida às infrações.

Em episódios como esse a celeridade inerente ao acordo administrativo é ameaçada, sendo esvaziada uma das vantagens de sua celebração à administração. Ainda que existam esforços interessantes para evitar a caracterização do termo de compromisso como um instrumento para procrastinação da ação da Comissão, seja pelo adiamento da decisão do processo administrativo (consequência de um longo período sem avanços na instrução do processo administrativo para a negociação e apreciação do termo de compromisso), seja pelo longo intervalo entre a intimação, a apresentação e a negociação de sucessivas propostas, intervalo para assinatura, publicação e cumprimento do acordado, é essencial aperfeiçoar o mecanismo, desde que preservada a segurança jurídica e a transparência necessária, nos termos da lei.

\subsubsection{Decisão pela Diretoria Colegiada. Conveniência e Oportunidade}

A CVM, a exemplo do que acontece com a autoridade policial no contexto do processo penal, não pode abrir mão de seu múnus público: a apuração, com a adoção dos procedimentos aplicáveis, das infrações e ilegalidades das quais venha a ter ciência, com a sua correspondente remediação. Qualquer omissão nesse tocante pode acarretar, inclusive, responsabilidade pessoal para o agente estatal que deixar de agir, caso tenha conhecimento de fato justificador de apuração.

Por outro lado, como previamente exposto, é razoável interpretar que a celebração do termo de compromisso com particulares - cujas condutas estejam sob

\footnotetext{
476 Disponível em: <http://www.cvm.gov.br/port/inqueritos/Termos/TermosCompr.asp >. Acesso em $23 \operatorname{dez} 2012$.
} 
investigação da CVM - não é desatenção ao poder-dever de apurar e punir ilícitos no mercado sob sua guarda, mas representa adoção de mecanismo alternativo para alcance do objetivo da Comissão, com a satisfatória regulação e fiscalização do mercado ${ }^{477}$.

Viu-se também que a decisão em relação à aceitação ou rejeição da proposta de termo de compromisso apresentada pelos administrados cabe unilateralmente à CVM. A "exclusivo critério" dessa autarquia, sujeita à análise de compatibilidade com o interesse público, nos termos do parágrafo $5^{\circ}$ do artigo 11 da Lei 6.385/76, é decidido se deve ser firmado ou não acordo administrativo pleiteado pelo administrado.

O artigo $9^{\circ}$ da D. CVM 390/01 $1^{478}$ especifica que, verificado o atendimento dos requisitos obrigatórios do parágrafo $5^{\circ}$ do artigo 11 da Lei 6.385/76 (atestado pela Procuradoria Federal Especializada), e concluída a tramitação da proposta pelo Comitê de Termo de Compromisso (com a eventual negociação e a obrigatória elaboração de parecer a respeito da conveniência e oportunidade na aceitação do acordo oferecido), passa o procedimento ao passo seguinte: a decisão do Colegiado - discricionária, e considerando alguns elementos, que serão objeto de referência oportunamente - em relação à aceitação ou não dos termos ofertados pelo agente sob investigação ${ }^{479}$.

Inicialmente será analisada a natureza discricionária ${ }^{480}$ da decisão de aceitação ou recusa da proposta encaminhada pelo investigado, "a exclusivo critério" da Comissão, amparada na análise de conveniência e oportunidade pelo Colegiado.

O excerto "se o interesse público permitir", condicionante do exercício da faculdade de adoção da proposta de termo de compromisso, é basilar à análise do emprego da discricionariedade (“conveniência e oportunidade”) a seguir desenvolvida ${ }^{481}$.

\footnotetext{
${ }^{477}$ EIZIRIK (1977, p. 54) ensina que “em regra, a finalidade da regulação do mercado de capitais, assim como de qualquer mercado, é a de fazer com que a organização da indústria apresente eficiência no modo pelo qual os recursos são alocados, de maneira que obtenham o máximo retorno e eficiência operacional, isto é, que o processo de alocação dos recursos se dê ao custo mais baixo".

478 "A proposta de celebração de termo de compromisso, acompanhada do parecer do Comitê de Termo de Compromisso, será submetida à deliberação do Colegiado, que considerará, no seu exame, a oportunidade e a conveniência na celebração do compromisso, a natureza e a gravidade das infrações objeto do processo, os antecedentes dos acusados e a efetiva possibilidade de punição, no caso concreto.”

479 “A decisão do Colegiado da entidade de acolher ou não a proposta de celebração de termo de compromisso depende também do juízo discricionário de seus Diretores e Presidente. Compete ao Colegiado da CVM analisar, além dos requisitos para a sua celebração (cessação do ilícito e indenização dos prejuízos), a conveniência e a oportunidade das demais obrigações a que a proponente voluntariamente se submete através do termo. [...] Cabe portanto ao Colegiado fazer um efetivo custo de ponderação a respeito do que é mais benéfico ao mercado: a celebração do termo proposto ou o indeferimento da proposta". DUBEUX (2006, p. 99).

480 “O Termo de Compromisso, ainda que sirva de instrumento da Administração Pública, apenas reafirma o dever de observância das normas jurídicas vigentes, não elidindo, novando ou mitigando o poder de polícia da CVM, sendo, outro ssim, a aceitação da proposta ato discricionário, pelo que deverá ser considerado o binômio oportunidade-conveniência." Parecer /CVM/ PJU/n. 006, de 10 de março de 1998.
} 
Diferentemente das situações em que o ordenamento determina atuação vinculada do administrador ${ }^{482}$, nas quais há resposta pré-definida ao comportamento do administrado, na decisão de aceitação ou recusa da proposta de termos de compromisso apresentada à CVM cabe ao seu órgão Colegiado interpretar o contexto subjacente para construir a decisão da CVM, que deve variar (positiva ou negativa) de acordo com as circunstâncias do caso real.

A lei confere o atributo da discricionariedade à decisão do Colegiado, o qual, naturalmente, não é ilimitado. É da essência de situações como a ora em estudo a conferência, pelo ordenamento, de maior autonomia ao administrador, em comparação com os atos vinculados (em que a autoridade está limitada à norma em todos os seus elementos). Ainda assim, a "liberdade" é restrita ao espaço circunscrito pela lei, devendo ser observados os princípios gerais da administração, previstos no artigo 37 da CF/88 e no artigo $2^{\circ}$ da Lei 9.784/99, que rege os processos administrativos e é aplicada de forma subsidiária (conforme seu próprio artigo 69) à Lei 6.385/76.

Ser a decisão discricionária ${ }^{483}$ não significa que ao Colegiado da Comissão é possibilitado encaminhar, de maneira livre, arbitrária ou aleatória, a deliberação sobre qualquer proposta de celebração de termo de compromisso. Não significa que qualquer posição adotada é certa e defensável, dependendo apenas de justificação ${ }^{484}$. Pelo contrário.

\footnotetext{
481 "Na verdade, o compromisso de cessação segue o regime de direito público na medida em que prepondera interesse público sobre o privado. De fato, é o interesse público que norteia o juízo de conveniência e oportunidade que a Administração exerce ao decidir se deve ou não ser celebrado o termo de compromisso, e em quais condições". CUEVA (2007, pp. 291-292).

482 "O Estado, ou quem faça as suas vêzes, na prática de atos administrativos pode se encontrar em duas posições antagônicas: ora deve se singir de estritas determinações legais, [...] ora pode apreciar a conveniência ou oportunidade dentro das soluções legais admitidas de forma indeterminada, de modo a proceder desta ou daquela maneira. [...] No segundo caso, diz-se que a Administração Pública, a respeito da prerrogativa de emanara o ato, ou o seu conteúdo, tem podêres discricionários ou políticos, e, assim, o ato administrativo é de caráter discricionário ou político. [...] Tem a prerrogativa de verificar, ante as condições de fato alegadas pelo particular, a conveniência ou oportunidade de deferir ou indeferir o pedido, em atenção aos elementos considerados, segundo o seu alto critério". BANDEIRA DE MELLO (1969, pp. 420-422).

483 "Noutros casos, a lei deixa a autoridade administrativa livre na apreciação do motivo e do objeto do ato, ou de ambos ao mesmo tempo. No que respeita ao motivo, essa discrição se refere à ocasião de praticá-lo (oportunidade) e à sua utilidade (conveniência)". SEABRA FAGUNDES, (1957, p. 94).

484 "Está totalmente superado, por ser inteiramente equivocado, o entendimento segundo o qual a discricionariedade que a lei confere ao agente legitima qualquer conduta [...]. Quando a Lei confere ao agente público competência vinculada, isto significa que a lei já escolheu previamente qual a única e melhor conduta para a plena satisfação do interesse público. Quando a lei confere ao agente público competência discricionária, isso significa que a lei atribuiu ao agente o dever-poder de escolher a melhor conduta, dentre um universo de condutas possíveis, para a plena satisfação do interesse público. [...] Em tese é possível afirmar que a lei estaria validando previamente quaquer das condutas possíveis, mas em concreto, diante do caso concreto, sempre haverá uma só conduta mais adequada à plena satisfação do interesse público". DALLARI e NOVIS (2008, p. 21).
} 
Cada caso tem apenas uma resposta correta a ser dada pela administração ${ }^{485}$, e cabe ao gestor público a tarefa de verificar qual a alternativa exata entre as apresentadas pela legislação ${ }^{486}$ (no caso da CVM, aceitar ou recusar o acordo proposto), e fundamentar sua decisão ${ }^{487}$.

Naturalmente, o exercício de atos administrativos discricionários é bastante mais difícil e complexo, o que explica a competência do órgão colegiado, tendente a proferir, em média, decisões mais adequadas, beneficiadas pelo debate de ideias e confronto de opiniões, se comparadas às decisões monocráticas ${ }^{488}$.

A Diretoria da CVM é levada a decidir, a cada termo de compromisso proposto, se o adequado é optar pela imperatividade (a atuação chamada típica, com apuração de responsabilidade e aplicação de sanções) ou pela consensualidade (com a

485 “O termo de compromisso não é uma panaceia, nem usado de forma desmedida. A CVM só assina o acordo quando entende que é oportuno e conveniente" Declaração da Diretora Luciana Pires Dias, ao jornal Valor Econômico, extraída da matéria "Projeto veta acordo para 'insiders'.", de autoria de Denise Carvalho, veiculada em 25 de agosto de 2011, pp. D1 e D9.

${ }^{486}$ Naturalmente, a decisão discricionária a respeito da aceitação ou não do termo de compromisso proposto pelo investigado não é a única situação em que o Estado - representado por agente público competente deve escolher entre opções oferecidas pela legislação, após o exame de conveniência e oportunidade acima relatado. Existem diversas outras situações em que à administração pública é facultado, sempre pelo quadro legislativo vigente, optar entre adotar ou não determinada medida. Exemplifique-se com, por exemplo, a alienação de bens imóveis da União ou a inscrição de ocupação, respectivamente tratadas nos artigos 23 e $7^{\circ}$ da Lei 9.636, de 15 de maio de 1998. Em tais comandos legais inclusive há referência expressa à análise fundamentada na conveniência e oportunidade de tais atos.

${ }^{487}$ Em consonância com o princípio da motivação, pelo qual a decisão de aceitar ou não a proposta de termo de compromisso deve ser fundamentada pela Autarquia. Tal fundamentação não necessariamente deve ser extensa, mas deve sempre existir e evidenciar a finalidade de sua atuação. Adotando tal expediente é possível afastar a caracterização de vícios que atacam a legalidade de atos administrativos (inclusive minimizar a chance de arbitrariedades). Tais vícios podem, inclusive, ensejar a invalidação dos atos, com o acionamento do controle externo dos atos administrativos, fundamentado no artigo $5^{\circ}$, XXXV, da Constituição Federal.

${ }^{488}$ Nesse sentido, manifestação do hoje ex-Presidente da CVM, Marcelo Fernandez Trindade, em declaração de voto na apreciação de proposta de termo de compromisso aplicável ao Inquérito Administrativo CVM n. 08/01: "Em minha opinião o exame da conveniência e oportunidade de celebrar-se Termo de Compromisso é das tarefas mais árduas que se impõem à CVM. Com efeito, ao decidir sobre a matéria, o Colegiado, diante dos elementos da acusação e da defesa, é chamado a verificar: (a) a probabilidade de acolhimento da acusação, diante das provas existentes e da defesa produzida; (b) a relevância, para o mercado de valores mobiliários, de uma manifestação de mérito da CVM sobre o caso concreto, seja condenatória, seja absolutória; e (c) a relevância e oportunidade das condições propostas para o Termo de Compromisso. Tal verificação importará, naturalmente, em juízo em grande parte de caráter subjetivo, por parte dos membros do Colegiado, o que está em linha com o disposto no parágrafo quinto do art. 11 da Lei 6.385/76 - que faculta à Comissão, 'a seu exclusivo critério, se o interesse público permitir', celebrar o Termo de Compromisso". Também, a posição do então Diretor Sergio Weguelin, no voto proferido na apreciação de proposta de celebração de termo de compromisso pelos acusados no rocesso Administrativo Sancionador CVM 17/2003, com data de $1^{\circ}$ de agosto de 2006: "Esse juízo de oportunidade, esclareço logo, nem sempre é fácil de ser feito, já que muitas vezes não é possível comparar 'na mesma moeda' o prosseguimento do processo sancionador com a celebração de termo de compromisso. Muitas vezes é difícil discernir com clareza o que é melhor para a regulação do mercado de capitais.Este parece ser justamente o caso do processo administrativo sancionador em questão. Não se vê à primeira vista o que traria melhor efeito à regulação, o julgamento ou a assinatura do termo de compromisso. É preciso tempo e maturação para se chegar a uma conclusão consistente". 
celebração do termo de compromisso), para ofertar a melhor resposta ao mercado ${ }^{489}$ e programar a política de regulação da maneira mais eficiente ${ }^{490}$.

A decisão deve valorar se o acordo, conforme proposto, será benéfico à atenção dos fins decorrentes das atribuições da CVM (indicados no artigo $4^{\circ}$ da Lei 6.385/76), ou se o proposto não se afigura suficiente para satisfazer, sempre sob o prisma da eficiência, os fins centrais da atividade da Comissão - ou seja, a promoção do funcionamento regular do mercado, com estímulo a seu desenvolvimento (necessariamente amparado na credibilidade das instituições e do próprio mercado), diretamente relacionada à proteção dos agentes (sendo assegurado aos participantes que infrações às regras não serão toleradas) ${ }^{491}$.

Considerando a necessidade de efetuar a melhor aplicação possível dos recursos escassos disponíveis à regulação, a CVM deve empreender análise dos custos e benefícios decorrentes da aceitação ou não de cada um dos termos de compromisso apresentados pelos particulares, sempre decidindo pela alternativa que propicie "a maximização do interesse coletivo" ${ }^{, 492}$.

Sobre a racionalidade da decisão, vale transcrever, por sua clareza e concisão, parágrafo redigido pelo então Conselheiro Luis Fernando Schuartz, no contexto de análise de proposta de termo de compromisso apresentado ao $\mathrm{CADE}^{493}$, plenamente aplicável às decisões tomadas pela Diretoria da CVM:

“[...] 5. A análise da conveniência e oportunidade da proposta deve, a meu ver, ser realizada a partir de um critério 'consequencialista' de decisão, i.e., da

\footnotetext{
489 Nunca descartando a adoção do metodo tradicional, da apuração e julgamento de condutas, pois a conclusão, na avaliação de cada caso, pode indicá-la como sendo a mais apropriada. Nas palavras de TANURE (2005, p. 14), então procurador federal da CVM: "Vale dizer: se, para realizar seu objeto, necessitar se valer de seu poder punitivo, não deve vacilar em fazê-lo, pois as sanções que aplicar, além do caráter pedagógico e educativo dos agentes infratores, terão, sobretudo, por objetivo manter a higidez desse mercado".

${ }^{490}$ PALMA (2010, p. 248).

491 "De qualquer modo, deve-se ressaltar que o interesse público tem papel fundamental na decisão de se celebrar um termo de compromisso. É este quem dirá se é melhor, no caso concreto, permitir a celebração do termo de compromisso e assim repararem-se mais rapidamente os danos sofridos por terceiros, ou se não há esta necessidade, prosseguindo o processo administrativo. Neste último caso, resultará apenas na aplicação de uma penalidade ao infrator caso este seja considerado culpado, sem qualquer compensação para os prejudicados". Voto da Diretora Norma Parente (datado de 4 de agosto de 2004) na avaliação de proposta de acordo apresentada no contexto do Processo Administrativo Sancionador CVM N. TA RJ 2003/7697.

492 "[...] a atividade regulatória envolve uma ponderação entre custos e benefícios da regulação; tal função envolve poderes quase-legislativos, quase-executivos e quase-judiciais; nesta ultima etapa, a ponderação deve considerar se da imposição de uma penalidade resultará a maximização do interesse coletivo representado pela atividade regulatória; do contrário, tala análise deve recomendar o acordo substitutivo, se dele resultar maior proveito geral". (SOUTO, 2005, p. 125).

${ }^{493}$ Voto do Conselheiro do CADE Luis Fernando Schuartz, relator do Requerimento n. 08700.004221/200756, no contexto do Processo Administrativo 08012.011142/2006-79, datado de 28 de novembro de 2007, disponível para acesso em 〈http://www.cade.gov.br/temp/D_D000000320991730.pdf>, acesso em ago2012, tratado de forma mais detida no item 3.3.4.1 acima.
} 
valoração das consequências associadas à decisão de celebrar o TCC e à decisão de não celebrar o TCC tal como este se apresenta, contando-se a decisão de celebrar o TCC como 'conveniente e oportuna' do ponto de vista da Administração Pública se e somente se as consequiências esperadas a ela associadas forem, desse ponto de vista exclusivamente, 'estritamente preferíveis' àquelas associadas à decisão de não celebrá-lo.” (grifos no original)

Tanto nos casos em que o Colegiado da Comissão decidir aceitar o acordo oferecido, quanto naqueles em que esse órgão entender inconveniente ou inoportuno celebrar o compromisso, deve ser possível verificar o caráter preventivo e pedagógico da posição adotada. A sinalização, pela CVM aos agentes do mercado, de existência de regulação, fiscalização e consequências aos infratores deve ser identificável tanto no conteúdo do termo de compromisso a ser celebrado ${ }^{494}$ (que deve ser entendido pelos compromissários não como uma medida menos rigorosa com relação aos comportamentos inapropriados ${ }^{495}$ - sob pena de enfraquecer a função educativa do instituto e da atuação sancionatória de maneira global ${ }^{496}$-, mas como método alternativo de tutela do mercado e coibição de ações indesejadas ${ }^{497}$ ), quanto na dosimetria da punição administrativa ${ }^{498}$.

Ainda sobre a discricionariedade da decisão do Colegiado, a qual não está sujeita a regras ou balizas além das limitações legais, interessante notar as semelhanças e diferenças entre o desfecho dos Processos Administrativos Sancionadores 18/2008 e 16/2008. As condutas objeto de investigação em ambos os casos eram relativamente assemelhadas, abordando falhas no atendimento do dever de diligência de administradores de companhias. No Processo Administrativo Sancionador 18/2008 houve julgamento administrativo, realizado em 14 de dezembro de 2010, no qual as dez condenações incluíram multas de $\mathrm{R} \$ 200.000,00$ e $\mathrm{R} \$ 400.000,00$, além da inabilitação por três anos de um acusado e absolvição de outros quatro acusados. Registre-se que todas as propostas de

\footnotetext{
${ }^{494}$ Segundo GRINOVER (2008, p. 84), “[...] o conteúdo do compromisso de cessação de prática [...] deve considerar o caráter preventivo do ato, bem como a extensão da controvérsia que lhe é subjacente".

495 “[...] que como qualquer outro sistema punitivo está baseado no poder de intimidação que desperta junto ao transgressor em potencial", na dicção de ARAGÃO e SANTOS (1979, p.6).

${ }^{496}$ Sobre o tema, ainda ARAGÃO e SANTOS (1979, p. 4) afirmam que "[...] caso contrário, ciente de que com o consent decree poderá furtar-se aos vexames de um inquérito, sendo-lhe aplicada pena relativamente branda, o indiciado teria mais um elemento favorável na relação custo/benefício da infração que pretendesse cometer".

497 Ainda que de forma atécnica, visto inexistir "substituição da pena", mas a adoção de ferramenta alternativa, MORAES (1999, p. 111) sustenta que: “A punição existe [...] sendo substituída, em parte, pela ação reparadora a que se compromete o acordante. Esta aí reconhecida a aplicação do princípio da utilidade da pena administrativa, consagrado pela doutrina e que vem merecendo crescente aplicação nos julgamentos de infrações administrativas".

${ }^{498}$ Importa esclarecer que, ao contrário do processo judicial, em que o magistrado aplica uma penalidade com os olhos voltados para o passado, isto é, para a conduta ilegal anteriormente praticada, os agentes reguladores devem ser orientados por uma interpretação prospectiva, preocupados com as consequências de suas decisões, no que se destaca o aspecto pedagógico da pena. (SOUTO, 2005, p. 125).
} 
termo de compromisso foram rejeitadas, inclusive propostas em montante idêntico ao da condenação que posteriormente viria a ser determinada pelo Colegiado a alguns acusados.

Já no caso 16/2008, o Colegiado da Comissão, após recusar uma proposta inicial no montante equivalente a $\mathrm{R} \$ 200.000,00$ "por imputação" (bastante assemelhada às propostas rechaçadas no Processo Administrativo Sancionador 18/2008), aceitou novas propostas, no valor de $\mathrm{R} \$ 800.000,00$ para 15 dos 16 proponentes, e compromisso no valor de $\mathrm{R} \$ 1.200 .000,00$, totalizando o valor de $\mathrm{R} \$ 13.200 .000,00$.

Comparando o valor da condenação/compromisso total pago pelos administradores em cada um dos casos, é possível perceber que, no caso 16/2008 (celebração dos termos de compromisso), esse montante foi 5 vezes maior se comparado ao desfecho do outro caso, sendo recolhido em curtíssimo prazo. No caso das multas, além do recurso de ofício ao CRSFN, a condenação poderá ser questionada judicialmente, sendo pouco provável que os valores sejam efetivamente despendidos antes de alguns anos da decisão administrativa.

Ademais, as multas impostas aos administradores responsabilizados não alcançaram o teto aplicável, sendo a mais alta, no valor de $\mathrm{R} \$ 400.000,00$, enquadrada no limite estabelecido na Lei 6.385/76, já analisado ${ }^{499}$.

Coloca-se a dúvida se, considerando o caso específico, agiu bem a CVM ao aceitar os termos (celebrados em conjunto com o MPF, prevenindo ações de cunho civil e coletivo), depois de terem recusado acordo em situação não muito diversa. Há argumentos possíveis para sustentar a adequação da decisão do Colegiado da CVM sobre a celebração dos termos no caso analisado (extinção do risco de absolvições, efetividade da decisão, valor a ser arrecadado superior ao teto limitador das multas, desnecessidade de continuidade do processo administrativo sancionador, com alocação mais eficiente dos recursos e sinalização ao mercado de que os termos de compromisso constituem alternativa viável para os casos, porém não necessariamente "barata"), e também fundamentos contrários à celebração dos acordos no caso concreto (as condutas deveriam ser julgadas para manutenção da linha de atuação exposta no caso anterior; pela gravidade e danos causados à companhia havia necessidade de julgamento e condenação, inclusive em penas restritivas de direitos, não se limitando aos compromissos pecuniários, dos quais os administradores tendem a ser ressarcidos pelas seguradoras - aumentando o custo do prêmio dos seguros, em prejuízo à companhia contratante e a seus acionistas).

\footnotetext{
${ }^{499}$ Item 4 acima.
} 
Também se questiona se os administrados obtiveram o melhor resultado possível, no sentido de alocação dos recursos disponíveis, ao adaptarem as propostas de termos às exigências da $\mathrm{CVM}^{500}$.

Os itens a seguir apresentam os elementos a serem considerados pela Diretoria Colegiada da CVM na apreciação da proposta de termo de compromisso ${ }^{501}$. Silente a Lei $6.385 / 76$ a respeito do tema (refere apenas o "exclusivo critério" da Comissão ${ }^{502}$ ), coube à regulamentação administrativa aclarar os critérios do processo decisório, os quais foram determinados pelo artigo $9^{\circ}$ da D. CVM 390/01 ${ }^{503}$.

\subsubsection{Natureza e gravidade das condutas apuradas}

Preenchidos os requisitos essenciais, as propostas de acordo administrativo apresentadas à Comissão de Valores Mobiliários são submetidas à avaliação da Diretoria Colegiada dessa autarquia, a qual tem poderes amplos para aceitar ou recusar o oferecido, inexistindo qualquer possibilidade de revisão de tal decisão ${ }^{504}$.

\footnotetext{
500 "Embora o desfecho tenha sido oneroso para os acusados, há quem avalie que a CVM foi branda diante da gravidade do caso. Principalmente porque, sem o julgamento, nenhum dos envolvidos poderá ser tachado como culpado. Já os advogados que acompanharam o caso afirmam que o encerramento foi favorável, inclusive, para a própria autarquia. 'Se o processo fosse levado adiante, haveria uma absolvição geral', avalia uma das fontes envolvidas. Nesse ponto, mais uma diferença em relação ao caso da [Companhia afetada pelas condutas apuradas no Processo 18/2008]. Enquanto no julgamento da empresa de alimentos a acusação atribui culpa aos executivos após avaliar a existência de falhas na governança corporativa e nos controles internos, na [Companhia afetada pelas condutas apuradas no Processo 16/2008], a documentação que comprova o restrito nível de acesso de cada um dos envolvidos às informações financeiras provavelmente os isentaria de responsabilidade." Item "Panorama" da Revista Capital Aberto, Outubro de 2012, p. 9.

${ }^{501}$ Sendo os vetores decisórios da aceitação ou não das propostas, como não poderia deixar de ser, de grande interesse dos agentes e estudiosos. Com o escopo de promover a discussão em debate do qual particiou, Viviane Prado indagou, não recebendo respostas objetivas, "quais são os critérios para firmar um termo de compromisso ou não? É bom se pensar em critérios ou não? Como é que isso é visto dentro da instituição que está decidindo por fazer ou não o termo de compromisso?" (Cadernos Direito GV, Seminário 38, v. 7, n. 6, nov. 2010, p. 33).

${ }^{502}$ Como advertido no Parecer/CVM/PJU/005, de 10 de março de 1998 (embora não se concorde de forma plena com a conclusão, tendo em vista que os requisitos expressos nos incisos do parágrafo $5^{\circ}$ do artigo 11 , combinados com a racionalidade do sistema de acordos substitutivos, parecem ser suficientes a um balizamento, ainda que mínimo da decisões do Colegiado): “[...] a Lei 6.385/76, em seu artigo 11, não estabelece requisitos que permitam uma avaliação preliminar acerca do merecimento do acusado ou indiciado. Destarte, a lei não fornece parâmetros que permitam determinar, de antemão, se o emprego deste instituto ao caso concreto atingirá a finalidade colimada de efetivamente corrigir práticas inadequadas e prevenir maiores danos aos investidores".

${ }^{503}$ Nas palavras de EIZIRIK et. al. (2008, pp. 362-363), "O parecer do Comitê de Termo de Compromisso, juntamente com a Proposta para a celebração do acordo, serão submetidos à deliberação do Colegiado, que, após examinar a natureza e a gravidade das infrações objeto do processo, os antecedentes dos acusados e as possibilidades de aplicação de penalidade, no caso concreto, deliberará acerca da oportunidade e conveniência de sua celebração".

${ }^{504}$ Exceto pelo pleito de reconsideração da decisão que rejeitar a celebração. Há registro de casos em que o Colegiado efetivamente reconsiderou sua decisão, pois amparadas em premissas comprovadamente equivocadas (avaliação de proposta de termo de compromisso no âmbito do Processo Administrativo
} 
Em tal análise, o Colegiado deve atentar para o caput do artigo $9^{\circ}$ da D. CVM 390/01, claro em determinar a necessidade de serem consideradas, no exame da proposta, além da conveniência e oportunidade, "a natureza e a gravidade das infrações objeto do processo", os "antecedentes do acusado" e a "efetiva possibilidade de punição, no caso concreto".

O primeiro dos critérios acima listados já foi utilizado como embasamento para a rejeição de propostas de termo de compromisso ${ }^{505}$, embora diversos outros acordos versando sobre condutas tão ou mais gravosas tenham sido aceitos ${ }^{506}$.

Naturalmente, nenhum dos critérios, isoladamente, pode ser considerado como definitivo e restritivo à aceitação de propostas de acordo. Esses critérios ou devem ser justapostos aos essenciais, ou às vedações absolutas (caso das infrações à lavagem de dinheiro, ou do pretendido pelo projeto de lei em trâmite, que deseja vedar a celebração de acordos em procedimentos que apurem condutas relacionadas à negociação de valores mobiliários por titulares de informações ainda não divulgadas ou à manipulação do $\left.\operatorname{mercado}^{507}\right)$.

Sancionador CVM n. 12/2004) e outros em que, revestido de pedido de reconsideração, houve submissão de uma nova proposta de acordo (avaliação de proposta de termo de compromisso no âmbito do Processo Administrativo Sancionador CVM n. RJ 2006/3410) ou pleito para reabertura das negociações entre o Comitê e o administrado (Processo Administrativo Sancionador CVM n. 15/2004).

${ }^{505}$ Referência à análise de proposta de Termo de Compromisso encaminhada pelos indiciados no Processo Administrativo Sancionador CVM n. 17/02, realizada em 23 de junho de 2004, em que o Diretor Wladimir Castelo Branco Castro, após transcrever o artigo $9^{\circ}$ da D. CVM 390/01, atestou que "na proposta de celebração de Termo de Compromisso ora submetida à apreciação, os fatos que ensejaram a acusação que recai sobre a conduta dos indiciados são de natureza grave", e arrematou posicionando-se contrário à celebração de tal acordo: "[...] em face do exposto, considerados todos esses aspectos, voto no sentido de que não deva ser aceita a proposta de Termo de Compromisso apresentada pelos indiciados, determinado-se a comunicação da presente decisão aos interessados".

${ }^{506}$ Casos nos quais o Colegiado entendeu de maneira diversa à proposição da PJU, de que "aquele que pratica uma infração de enorme potencial lesivo, com características marcadamente dolosas, ainda que não reincidente, não deveria fazer jus a tal benefício, uma vez que sua punição terá repercussão mais positiva se encarada como exemplo para os demais agentes do mercado". (Parecer/CVM/PJU/005, de 10 de março de 1998). Interessante notar, em um exemplo dentre tantos outros (Processo Sancionador n. RJ 2010/2419), que a Diretoria Colegiada, diante de oferta de monta considerável, aceitou ("por entendê-la oportuna e conveniente, uma vez que o valor do compromisso se afigura proporcional à gravidade das imputações formuladas, sendo suficiente para desestimular a prática de condutas assemelhadas") proposta de acordo substitutivo em caso no qual o parecer do Comitê de Termo de Compromisso concluiu ser inconveniente, "em qualquer cenário, a celebração de Termo de Compromisso, considerando notadamente as características que permeiam o caso, tal qual o contexto em que se verificaram as infrações imputadas à proponente e a gravidade das condutas consideradas ilícitas". O Comitê, finalmente, destacou que o "caso demandava um pronunciamento norteador por parte do Colegiado em sede de julgamento, visando a bem orientar as práticas do mercado em operações que envolvam a aquisição do controle acionário de companhia aberta". Sobre o tema, inúmeras foram as manifestações de discordância em relação à decisão do Colegiado, entre as quais colocação de José Estevam de Almeida Prado, diretor da CVM entre 1993 e 1995, no sentido de que "O termo de compromisso assinado pelo grupo Vivendi não é proporcional ao vulto da aquisição da GVT (da ordem de R\$6 bilhões)" citado por PAHIM JR. (p. 69).

${ }^{507}$ Referido no item 7 supra. 


\subsubsection{Antecedentes}

Os antecedentes dos candidatos a compromitente devem também ser levados em consideração pelo Colegiado, em sua análise discricionária. A Procuradoria Jurídica da CVM já advertiu que "infratores contumazes, que possuem um passado pontuado de práticas ilícitas, dificilmente farão com que os objetivos didáticos e corretivos do termo de compromisso sejam alcançados" ${ }^{508}$.

Há registros de casos em que a inexistência de antecedentes foi referida como um dos vetores da aceitação da proposta, de acordo com a manifestação do Colegiado ${ }^{509}$, e outros nos quais a relação de condenações, processos administrativos pendentes de julgamento e até termos de compromissos celebrados pelos proponentes são suscitados para afastar a possibilidade de celebração de acordos substitutivos ${ }^{510}$.

$\mathrm{Na}$ hipótese de repetição de infrações por um mesmo agente, questiona-se a atenção ao escopo educativo do termo de compromisso ${ }^{511}$. Exemplo prático é o de um administrador, que ocupa posto de Diretor de Relações com Investidores de companhia aberta de economia mista, controlada pela União, que obteve aceitação do Colegiado da Comissão em 3 (três) ${ }^{512}$ propostas de termo de compromisso, todas versando sobre o mesmo tema - o desatendimento do dever de divulgar fatos relevantes imediatamente.

Ainda que tenha sido exigido um incremento (sensível) do valor pago como condição para celebração a cada nova negociação, fundamentado também no "histórico de

\footnotetext{
508 Parecer/CVM/PJU/005, de 10 de março de 1998.

509 Apreciação de proposta de celebração de Termo de Compromisso apresentada nos autos do Processo Administrativo Sancionador CVM n. RJ 2001/12130, conforme registro da Ata da Reunião do Colegiado de 9 de agosto de 2005, na qual consta que "Após expor o assunto, o Relator se manifestou no sentido de considerar atendidos os pressupostos legais para a celebração de termo de compromisso, por entender que o suposto ilícito não gerou prejuízo pecuniário aos acionistas ou ao mercado para se exigir a reparação dos danos, a prática foi única, não constando registro de antecedentes semelhantes praticados pelos Proponentes, bem como o direito postulado pelo reclamante já foi em parte atendido, devendo ser integralmente reparado com o compromisso a ser firmado nestes autos". - sem grifo no original.

510 Entre os quais as propostas de termo de compromisso apresentadas pelos acusados nos Processos Administrativos Sancionadores CVM n. RJ 2001/4474 e RJ 2008/9574, recusadas em 14 de dezembro de 2004 e 19 de dezembro de 2009, respectivamente.

${ }^{511}$ Conforme advertência de ARAGÃO e SANTOS (1979, p. 12), "É preciso, finalmente, destacar que a própria aceitação das ofertas de settlement deve ficar condicionada à inexistência de infrações particularmente graves ou de reincidência do indiciado".

512 Celebradas para suspensão dos Processos Administrativos Sancionadores RJ 2007/13889 (compromisso de pagar $\mathrm{R} \$ 100.000,00$, aceito em 30 de setembro de 2008); RJ 2009/3049 (compromisso de pagar $\mathrm{R} \$ 400.000,00$, aceito em 15 de dezembro de 2009); e RJ RJ 2009/6713 compromisso de pagar $\mathrm{R} \$ 1.000 .000,00$, aceito em 25 de maio de 2010).
} 
ocorrências do proponente" ${ }^{\text {513 }}$, cabe questionamento a respeito da utilidade dos termos, em seu efeito dissuasório, no presente caso.

\title{
9.2.5.3. Efetiva possibilidade de punição, no caso concreto
}

O exame da efetiva possibilidade de punição aparenta ter sido definido para evitar que, em casos instruídos e prontos para o julgamento, fosse oferecido e celebrado termo de compromisso. Parece claro que tal raciocínio deve ser sopesado e não imperar solitário $^{514}$.

Na hipótese de, momentos antes da sessão de julgamento de determinado caso - ou, eventualmente, após o início do julgamento (entre a manifestação de voto de um Diretor e outro) -, o acusado oferecer proposta de acordo pela qual haveria indenização relevante a todos os terceiros prejudicados, ainda que fosse clara a efetiva possibilidade de condenação (tendo em vista a instrução e manifestações apresentadas pela Diretoria no início do julgamento ${ }^{515}$ ), talvez fosse o caso de a Diretoria analisar e, eventualmente, aceitar a proposta.

Há, entretanto, um limitador à consideração do último critério do artigo $9^{\circ}$ da D. CVM 390/01. Ao contrário dos outros dois, esse critério não é verificado pelo Comitê, cabendo exclusivamente ao Colegiado mensurá-lo. Explique-se, com palavras do próprio Comitêt ${ }^{516}$ :

\begin{abstract}
“[...] Consoante entendimento já consubstanciado em sede de Termo de Compromisso, a análise do Comitê é sempre pautada pela realidade fática manifestada nos autos e os termos da acusação, não competindo neste momento processual adentrar em argumentos próprios de defesa, à medida que o seu eventual acolhimento somente pode ser objeto de julgamento final pelo Colegiado desta Autarquia, sob pena de convolar-se o instituto do Termo de Compromisso em verdadeiro julgamento antecipado".
\end{abstract}

\footnotetext{
${ }^{513}$ Expressão grafada no Parecer do Comitê de Termos de Compromisso datado de 13 de janeiro de 2010, referente ao terceiro Processo Sancionador.

514 Assim, é provavelmente correta em abstrato, embora não seja infalível a afirmação de MORAES no sentido de que "seria notoriamente ilegal a assinatura do termo de compromisso [...] que implique na renúncia, pela Autarquia, de sua atribuição sancionadora, quando estiverem comprovados os atos e práticas ilícitas". (1999, p. 111).

515 “[...] estou convencido de que a ponderação do Colegiado deve também 'pôr na balança' a consistência da acusação que é feita no processo administrativo sancionador. Sim, porque, quanto mais consistente e mais bem fundamentada em provas for a acusação, menor será a inclinação do Colegiado para celebrar termo de compromisso." Manifestação do Dirtor Sergio Weguelin, 1. ${ }^{\circ}$ de agosto de 2006, no Processo Administrativo Sancionador CVM 17/2003.

516 Trecho constante de dezenas de pareceres do Comitê de Termo de Compromisso, incluindo o produzido em 20 de julho de 2011, em resposta a proposta apresentada pelos acusados no Processo Administrativo Sancionador CVM N. RJ 2011/5750.
} 
Assim sendo, tal balizador tende a ser menos referido do que os demais, embora certamente influencie na formação de convencimento dos agentes públicos inclusive dos integrantes do Comitê -, embora a eles não seja dado fundamentar uma decisão com amparo específico no critério referido.

\title{
9.2.5.4. Irrecorribilidade da decisão
}

A decisão do Colegiado sobre a aceitação ou não de proposta de termo de compromisso é irrecorrível, inexistindo possibilidade de recurso a qualquer outro órgão, inclusive ao Conselho de Recursos do Sistema Financeiro Nacional - órgão responsável pelo julgamento de recursos contra decisões da CVM em julgamentos de processos sancionadores.

Sobre o tema, o Voto do Conselheiro do CRSFN, Valdecyr Gomes, em 29 de março de 2005, no Recurso n. 6019, originado do Processo CVM 1998/4733 (v.u.) é claro:

\begin{abstract}
"Em seu pedido de fls., os ora recorrentes pedem o provimento do recurso, com a extinção do processo ou, alternativamente, a assinatura de termo de compromisso, com os acréscimos que sejam entendidos aplicáveis ao caso. Para justificar este pedido alternativo, os recorrentes mencionam que a Procuradoria Jurídica da autoridade 'a quo' nada opôs à celebração do termo de compromisso, por estarem presentes os requisitos legais. A este respeito, vale destacar que o Colegiado da Autarquia rejeitou a assinatura de termo de compromisso por entender - conforme voto condutor da decisão - que a proposta feita pelos recorrentes limitava-se ao cumprimento das normas vigentes, sem novas obrigações que atendessem ao interesse público. [...] depreende-se, com clareza, que é da Comissão de Valores Mobiliários a competência para suspender o processo, em decorrência da assinatura de termo de compromisso. A esta cabe julgar a conveniência e a oportunidade de aceitar - ou não - o termo. E esta já se manifestou, oportunamente, quanto ao pedido. Assim [...] entendo ser este Conselho de Recursos incompetente para julgar o pedido alternativo, formulado pelos recorrentes."
\end{abstract}

\subsubsection{Causas de recusa pelo Colegiado}

É possível observar que uma parcela considerável dos termos propostos é recusada pela Diretoria Colegiada da CVM. A justificativa não é complexa: ou são casos nos quais não se recomenda a celebração de acordos pela natureza da infração a ser apurada $^{517}$, pelo histórico dos proponentes ou pelo estágio em que se encontra o

\footnotetext{
${ }^{517}$ Conforme voto da Diretora Norma Parente, em 4 de agosto de 2004, em deliberação que recusadou acordo administrativo no Processo Administrativo Sancionador CVM N. TA-RJ 2003/7697: "No caso, a infração por demasiado grave ao mercado de valores mobiliários não admite o não julgamento da matéria. Uma das funções do termo de compromisso é evitar que a sociedade sofra os danos advindos da conduta do interessado; mas, no caso em questão, tais danos já ocorreram, sendo até mesmo de difícil, se não impossível, quantificação. Portanto, não há conveniência e oportunidade na celebração de termo de compromisso.
} 
procedimento administrativo sancionador; ou as obrigações propostas pelo compromitente não eram, no entender do Colegiado, suficientes para ressarcir o prejuízo e garantir a interrupção da conduta ${ }^{518}$.

Também representam parte importante dos termos rejeitados aqueles em que os proponentes, em não havendo danos a terceiros identificados, propõem pagamento em valor insuficiente, no entendimento do Colegiado (e, usualmente, do Comitê de Termo de Compromisso, cujo parecer, como visto, auxilia a decisão da Diretoria), ou simplesmente apresentam proposta de cumprimento das regras impostas pela legislação e regulamentação administrativa $^{519}$.

Outro fundamento de parte significativa das recusas é a inexistência de proposição de acordos por alguns dos investigados, ainda que outros deles tenham apresentado ofertas de acordo enquadradas nos padrões entendidos como satisfatórios pelo Comitê de Termos de Compromisso e pela Diretoria Colegiada.

Exceto nos casos em que a aceitação de um termo com parte dos acusados produza benefícios extraordinários - como a cessação de condutas ainda existentes ou benefícios a terceiros lesados -, parece ser pertinente esse tipo de recusa, pois a aceitação de apenas alguns acordos "não caracterizaria qualquer ganho para a Administração, em termos de celeridade e economia processual, vez que decerto será dada continuidade ao

Ademais, já há outros casos semelhantes com julgamento em curso, não se justificando a adoção de procedimento diferenciado neste processo em particular".

518 “A propósito, parece importante registrar que o elevado e crescente número de decisões do Colegiado da CVM de aprovação de termos de compromisso não evidencia uma indiscriminada utilização do instituto. Pelo contrário. Quando são analisados os números de propostas apresentadas versus os números de propostas aprovadas ou rejeitadas, verifica-se que o Colegiado é bastante criterioso em suas análises, deixando, em muitos casos, de aprovar propostas formuladas, seja em razão da sua desproporcionalidade em relação à gravidade dos fatos, seja pelo não atendimento aos requisitos legais, ou mesmo porque algumas propostas se revelam, segundo o entendimento daquele órgão de cúpula, insuficientes para desestimular práticas semelhantes". WELLISCH e SANTOS (2009, p. 7).

519 Exemplos do último tipo são os termos recusados pela Diretoria nos Processos Administrativos Sancionadores CVM n. SP 2011/0799 (voto do Diretor Sergio Weguelin, em 23 de agosto de 2005): “É evidente, entretanto, que as propostas apresentadas não proporcionam nenhum benefício à regulação do mercado de capitais. Em síntese, os proponentes se obrigam a não agir ilicitamente, isto é, a não mais intermediarem valores mobiliários sem estarem autorizados pela CVM, bem como a não mais se valerem de documentação inidônea na intermediação de títulos. Esse comportamento, todavia, independe da assinatura de termo de compromisso com a CVM, pois que decorre das próprias normas do mercado de capitais."; e RJ 2003/3648 (voto da Diretora Norma Parente, em 3 de maio de 2005): "Ao analisar a proposta apresentada pela indiciada, verifica-se que a mesma, como afirmado pela SIN, de fato, nada contém além do mero cumprimento das normas, providência, aliás, que deve ser tomada independentemente da assinatura de Termo de Compromisso". 
procedimento administrativo com relação aos demais acusados, nos termos da legislação aplicável à matéria",520.

Além disso, tal decisão poderia dar causa a resultados diversos para administrados que adotaram exatamente a mesma conduta (o que é naturalmente possível ao existir a possibilidade de termo de compromisso parcial, mas não necessariamente é desejável).

Tal argumento, ainda que sólido, não é irrefutável (ao menos sob o ponto de vista da Diretoria Colegiada, quando de determinada composição), como decidiu a Diretoria, em 24 de agosto de 2010, em apreciação de proposta apresentada no âmbito do Processo Administrativo Sancionador 15/2008. Nesse caso, o argumento defendido pelos Diretores Eli Loria e Otavio Yazbek (no sentido de que "a eventual celebração de termo de compromisso com os acusados não traria economia processual significativa para a CVM, vez que o processo seguiria seu curso normal em relação aos demais acusados que não apresentaram proposta de termo de compromisso"), não foi suficiente para convencer os outros membros do Colegiado, que aceitaram proposta parcial em 24 de agosto de 2010.

O alerta apresentado pelos referidos Diretores vencidos confirmou-se adequado, pois o processo administrativo sancionador, conduzido em relação à metade dos acusados que não propôs acordo, foi julgado apenas em fevereiro de 2012, após prosseguir a instrução e demandar o emprego de recursos da autarquia, com os quais poderia ter sido efetuado o julgamento de todos os acusados inicialmente, incluindo-se os signatários do acordo substitutivo celebrado. A título informativo, a decisão de 2012 foi pela absolvição de todos, a qual segue ainda pendente de julgamento do recurso de ofício pelo $\mathrm{CRSFN}^{521}$.

\subsubsection{Consequências da aceitação da proposta}

A aceitação da proposta pelo Colegiado enseja a adoção de alguns procedimentos. O primeiro deles é a formalização do instrumento do acordo, com a preparação da minuta de acordo contendo as obrigações submetidas pelo administrado e aprovadas pelo Colegiado. O passo seguinte é a assinatura pelo compromissário (que pode ser representado por procurador) e pelo Presidente da Comissão de Valores Mobiliários ${ }^{522}$, conforme disciplinado no artigo $3^{\circ}$, parágrafo $1^{\circ}$, da D. CVM 390/01.

\footnotetext{
${ }^{520}$ Parecer do Comitê de Termo de Compromisso datado de 20 de junho de 2012, apresentado no sentido de recusa da proposta apresentada pelos acusados no Processo Administrativo Sancionador CVM n. RJ 2011/10415, a qual foi confirmada pela Diretoria Colegiada da CVM.

${ }^{521}$ Informação atualizada em dezembro de 2012.

522 “Quem deverá firmar o termo de compromisso com o indiciado é o Presidente do Colegiado, pois, de acordo com o art. 17, I, do Regimento Interno da Autarquia (Portaria n. 327, de 11.07.77, do Ministério da
} 
No momento da aceitação de uma proposta pode ser que o processo administrativo na qual se insere tivesse sido interrompido, pela apresentação de propostas de termo de compromisso por todos os acusados, ou já estivesse em curso (instrução e análise da peça acusatória, defesa e outros procedimentos necessários ao julgamento), em razão da existência de acusados que não formularam proposta de acordo ${ }^{523}$.

Quanto ao primeiro cenário, há suspensão do processo em relação aos acusados que tiverem sua proposta aceita pela Diretoria Colegiada e é sorteado um diretor relator para conduzir o julgamento administrativo em relação aos proponentes que tiveram sua oferta recusada. Caso todos os acusados tenham sido contemplados com a aceitação das respectivas propostas de termo de compromisso, o processo sancionador sequer é distribuído para julgamento, ficando suspenso pelo prazo necessário ao cumprimento das obrigações contraídas perante a autarquia ${ }^{524}$.

Já no segundo caso (proposta apresentada por parte dos acusados, sendo aceita), o caso segue seu trâmite regular, exclusivamente com relação aos administrados que não tiveram proposta submetida pela Comissão, permanecendo suspenso em relação aos compromitentes pelo prazo estipulado para adimplemento do compromisso celebrado $^{525}$.

Com a aceitação da proposta pela Comissão, forma-se o acordo entre a autarquia e o administrado, nos exatos termos propostos, o qual é objeto de formalização pela assinatura do termo. Por sua natureza, os acordos não podem ser modificados unilateralmente. Qualquer alteração necessita de concordância de ambas as partes, conforme referido no parágrafo $2^{\circ}$ do artigo $3^{\circ}$ da D. CVM 390/01 ${ }^{526}$.

Tal regra condiciona as alterações das condições do termo de compromisso à deliberação positiva do Colegiado da CVM, provocada por requerimento do administrado,

Fazenda), ele representa a CVM, ativa e passivamente, em juízo ou fora dele". EIZIRIK (Reforma, 1998, p. 268). Vale indicar que o Decreto 6.382, de 27 de fevereiro de 2008, aprovou a estrutura regimental da Comissão, na qual é estabelecida que a representação da CVM, em juízo ou fora dele, é incumbência de seu Presidente (artigo 29, II do Anexo ao decreto referido). É possível argumentar que a presidência, desempenhando função orgânica, presenta a entidade e não a representa.

${ }^{523} \mathrm{O}$ processamento das propostas de acordo e suas consequências é disciplinado na D. CVM 538/08, especificamente em seu artigo 14.

${ }^{524}$ No item correspondente, infra, será analisada a consequência de evetual inadimplemento das obrigações pactuadas em termo de compromisso e seu reflexo sobre o processo sancionador correspondente.

${ }^{525}$ No item correspondente, infra, será analisada a consequência de evetual inadimplemento das obrigações pactuadas em termo de compromisso e seu reflexo sobre o processo sancionador correspondente.

526 Após sua aprovação, as condições do termo de compromisso não poderão ser alteradas, salvo se, por requerimento da parte interessada, houver nova deliberação do Colegiado". CARVALHOSA e EIZIRIK (2002, p. 521). 
gerando segurança e certeza para as partes em relação ao pactuado (constituindo direito adquirido do administrado ao passo que, em regra, a autarquia não pode rever sua decisão).

Em outros contextos, tanto alienígenas ${ }^{527}$ quanto em outros campos da atividade administrativa $^{528}$, requer-se a existência de um motivo para a alteração dos acordos, o que não existe (ao menos expressamente) no contexto do mercado de valores mobiliários, embora pareça pouco provável a aceitação de modificação de condições já aceitas pelo Colegiado caso inexista justificativa plausível.

Há registro de argumentos indicando atitude pouco colaborativa de terceiros a serem indenizados ${ }^{529}$ e a modificação de cenário econômico e financeiro entre a pactuação do acordo e o momento de seu pagamento ${ }^{530}$ como sendo motivos a serem considerados para sua alteração. Não é razoável concordar com nenhum dos dois, em regra, porquanto no primeiro caso seria possível adotar medidas processuais (consignação em pagamento) para disponibilização ao credor do valor a ser pago e, no segundo, ainda que a ideia pareça pertinente, não há, em regra, prazo suficiente entre a aceitação da proposta, sua formalização e seu adimplemento para a ocorrência de mudança pela qual o proponente não deva se responsabilizar.

É possível invocar casos pretéritos em que termos de compromisso aprovados pela Comissão tiveram seus teores alterados, por variados motivos, como o acordo celebrado no contexto do Processo Administrativo Sancionador RJ2003/5473 e do Processo RJ2002/7017 (um único termo para ambos os procedimentos administrativos ${ }^{531}$ ),

\footnotetext{
527 "Saliente-se que, no direito norte-americano, os termos do acordo firmados pelas partes podem vir a ser modificados. Para tanto, é preciso provar inequivocamente que existem graves erros ou circunstâncias novas e não previstas, sendo certo que qualquer modificação deve ser submetida à apreciação do Poder Judiciário e que haverá, necessariamente, uma audiencia com as partes”. EIZIRIK (Reforma, 1998, p. 265).

${ }^{528}$ No direito concorrencial há previsão de revisão do conteúdo em caso de onerosidade excessiva, conforme definido no parágrafo 12 do artigo 85 da Lei 12.529/11: “As condições do termo de compromisso poderão ser alteradas pelo Cade se se comprovar sua excessiva onerosidade para o representado, desde que a alteração não acarrete prejuízo para terceiros ou para a coletividade".

529 "Pode-se citar como exemplo desse tipo de situação a hipótese em que é firmado um termo de compromisso [...] e o terceiro 'prejudicado' não aceita o valor acordado, fazendo 'chantagem' com o indiciado ou acusado, causando-lhe dificuldades para cumprir a sua parte do acordo e tornando-o impossível de ser levado a cabo. Nesse caso, poder-se-ia modificar os termos do acordo, sendo certo que o compromissário se desobriga perante a CVM, se demonstrar que realizou todos os esforços no sentido de cumprir o acordado. A obrigação do compromissário, com relação ao valor, é de meio e não de resultado. Basta que comprove que despendeu o melhor esforço para indenizar os prejuízos decorrentes de sua atuação". EIZIRIK (Reforma, 1998, p. 271).

530 “[...] pode acontecer, ainda, que tenha sido fixado um valor a título de indenização e que, à época do seu pagamento, as circunstancias econômicas e financeiras do indiciado tenham sofrido alterações substanciais de forma que a obrigação torna-se impossível de ser cumprida. Mais uma vez, incide a regra da rebus sic standibus". EIZIRIK (Reforma, 1998, p. 265).

${ }^{531}$ Existindo entendimento do Colegiado a respeito da possibilidade de mais de um processo administrativo ser suspenso pela assinatura de uma única proposta, como decidido na análise do acordo celebrado no contexto dos Processos Administrativos Sancionadores CVM n. SP 2002/0440 e SP 2005/0099, efetuada em
} 
no qual um dos compromitentes solicitou ao Colegiado da CVM que aprovasse a substituição do termo "multa" para "ressarcimento à CVM", no trecho do termo a respeito da natureza do pagamento pactuado. A Diretoria, então, decidiu concordar com a alteração, desde que ficasse consignado tratar-se de "condição para a celebração do Termo de Compromisso", conforme registrado na ata da Reunião do Colegiado realizada em 13 de dezembro de 2005.

Outra modificação não estrutural em conteúdo de acordo foi aprovada pela Comissão em termo firmado no Processo Administrativo Sancionador CVM n. 16/01, a pedido de um administrador da sociedade compromitente, porque no item "Aspectos Fáticos e Legais do Inquérito" 532 , constante do preâmbulo do termo, havia sido reproduzida referência à conclusão da Comissão de Inquérito, indicando-o como responsável direto e exclusivo pela conduta sobre a potencial infração a respeito da qual versou o acordo. A Diretoria da Comissão, em decisão de 16 de maio de 2005, aprovou a modificação da redação, e o consequente ajuste às correspondentes cláusulas do acordo, para suprimir qualquer ideia de julgamento das condutas, em linha com o espírito do termo.

Bastante mais interessante é o caso do termo de compromisso firmado em pela CVM com administradores de companhia aberta em 14 de julho de 2010, pelo qual os compromitentes obrigaram-se a atuar para que a companhia por eles administrada efetuasse o pagamento de dividendos que injustificadamente haviam sido sonegados aos acionistas. Acordaram com a CVM o pagamento aos acionistas do valor dos dividendos devidos, devidamente corrigido, em parcelas, além da regularização da situação, com apresentação de documentos obrigatórios em atraso.

Tudo quanto pactuado vinha sendo cumprido pontualmente até que, no final de 2011, os dividendos da companhia foram objeto de penhora em decorrência de execuções fiscais, restando impossibilitado o seguimento do pagamento das parcelas. A companhia informou à Comissão que recorreu das decisões que determinaram as penhoras, e que se mantinha firme no propósito de adimplemento do acordo administrativo celebrado, embora fosse momentaneamente impossível adimplir as parcelas por vencer. Consultada, a

reunião datada de 15 de fevereiro de 2006, ainda que a Procuradoria Federal Especializada tenha apresentado manifestação contrária a tal possibilidade, registrada no Parecer do Comitê de Termo de Compromisso lavrado em 25 de janeiro de 2006: "A letra do $\S 5^{\circ}$ do art. 11 da Lei $n^{\circ} 6.385 / 76$ não parece permitir que apenas uma proposta de ajustamento de conduta ponha fim a vários processos administrativos; salvo nos casos em que a própria Administração reconheça a existência de erro no processamento em separado, dos processos administrativos que, na origem, deveriam ter integrado os mesmos autos".

532 Tal tipo de informação não é mais inserida nos acordos, os quais são, atualmente, bastante mais sintéticos e diretos, tratando exclusivamente das obrigações assumidas e sem referências delongadas ao caso em que se insere. 
Procuradoria Federal Especializada manifestou-se no sentido de que as execuções fiscais não se enquadravam como "motivo superveniente e não imputável" aos proponentes, conforme previsto no artigo $3^{\circ}$, parágrafo $3^{\circ}$, da D. CVM 390/01, mas que o Colegiado pode decidir autorizar a prorrogação do prazo para cumprimento da obrigação compromissada, promovendo alteração nas condições, conforme previsto no artigo $3^{\circ}$, parágrafo $2^{\circ}$, da D. CVM 390/01, inclusive citando precedente em que já havia sido feito $^{533}$.

O Colegiado, em reunião de 29 de novembro de 2011, decidiu autorizar a prorrogação do prazo para cumprimento do compromisso, por considerar que, antes da penhora, os pagamentos vinham sendo pontuais, mais da metade do valor devido já havia sido pago, o valor a ser pago à CVM como condição de aceitação do termo fora quitado tempestivamente e a companhia vinha mantendo seus registros atualizados de forma correta, tudo evidenciando boa-fé dos compromissários.

\subsubsection{Consequências da recusa da proposta}

No momento da rejeição de uma proposta é possível que o processo administrativo na qual se insira tivesse sido interrompido, em decorrência de submissão de propostas de termo de compromisso por todos os envolvidos, ou já estivesse em curso (instrução e análise da peça acusatória, defesa e outros procedimentos necessários ao julgamento), em razão da existência de acusados que não formularam proposta de acordo.

Em todos os casos enquadrados no primeiro cenário, há um sorteio para definição do Diretor incumbido de relatar o processo administrativo sancionador, para apurar e julgar conduta de todos os acusados que tiveram sua oferta recusada.

Já no caso de rejeição à proposta apresentada por parte dos acusados, considerando já estar em curso processo administrativo sancionador em relação aos acusados que não apresentaram pedido de acordo substitutivo, os proponentes que tiveram suas minutas de acordo negadas são incluídos no rol de acusados, sendo conduzido normalmente o processo sancionador.

\footnotetext{
533 "Nesse tocante, citou o Processo Administrativo CVM n ${ }^{\circ}$ RJ2009/1987, no âmbito do qual o Colegiado deliberou por alterar cláusula de Termo de Compromisso celebrado com esta autarquia, com fundamento no princípio da razoabilidade. [...] Refere-se a pedido de reconsideração apresentado pelo Banco Safra de Investimento S.A. da decisão do Colegiado de 24.03.09, que, respondendo a consulta do Requerente, considerou que a Cláusula $1^{\mathrm{a}}$ do Termo de Compromisso, celebrado entre o Banco Safra e a CVM em 02.08.07 (PAS CVM nº RJ2006/6235), vedava a constituição, pelo banco, de outros fundos de investimento Curto Prazo nos termos da Deliberação ANBID n 29/2006”. Conforme memorando de 22 de novembro de 2011, subscrito pelo então Superintendente Geral da Comissão, Roberto Tadeu Antunes Fernandes.
} 


\subsubsection{Publicidade do teor do acordo}

Os termos de compromisso aprovados são, após a coleta das assinaturas ${ }^{534}$, encaminhados para publicação no Diário Oficial da União. O objetivo é tornar todo "o processo administrativo o mais transparente possível, em atenção aos princípios da moralidade e da publicidade (CF, art. 37, caput) ${ }^{, 535}$.

Adicionalmente, todas as decisões de aprovação ou recusa dos termos de compromisso e os pareceres do Comitê de Termo de Compromisso apresentados à Diretoria Colegiada podem ser acessados pela página da Comissão na "Internet" ${ }^{, 536}$, onde também é possível encontrar referência à data de assinatura e de publicação de cada um dos acordos no periódico oficial.

O teor integral dos termos, da mesma forma, pode ser consultado no mesmo endereço eletrônico.

\subsubsection{Acompanhamento do cumprimento}

A Lei $6.385 / 76$ (especificamente o parágrafo $7^{\circ}$ do artigo 11) exige que os acordos tragam previsão expressa do prazo para cumprimento das obrigações pactuadas. Por não existir detalhamento legal sobre o referido prazo, a doutrina sugeriu que a CVM regulamentasse em até no máximo 6 meses, considerando o escopo de conferir celeridade à atividade da administração ${ }^{537}$.

Certamente tal intervalo pode variar, de acordo com a natureza ${ }^{538}$ da obrigação, mas não deve ser demasiadamente longo, considerando a suspensão dos processos

\footnotetext{
${ }^{534}$ Os acordos entre a autoridade administrativa brasileira e os acusados em processos sancionadores estão perfeitamente válidos e efetivos a partir da assinatura do termo. Diferentemente de tal previsão, boa parte dos acordos entre a SEC e os agentes atuantes no mercado dos Estados Unidos da América, em que, pela natureza judicial das reclamações da autoridade regulatória, quaisquer acordos em juízo dependem de homologação. Como aponta TANJI (2009, p. 99), “O 'consent decree', resultado de negociação entre SEC e o investigado, pode ser implementado administrativamente ou perante o Poder Judiciário”. MORAES (1999, pp.100, 105) também trata do tema, e EIZIRIK (Reforma, 1998, p. 264), ainda sobre a experiência americana, ressalta que "É importante destacar a importância do Poder Judiciário neste processo: uma vez firmado o acordo entre as partes, este deverá ser submetido à apreciação do Juiz, que o homologará. O acordo não é, propriamente, resultado de uma decisão judicial, embora dele o Judiciário participe - ele provém de um consenso entre ambas as partes, resultante de mútuas concessões".

${ }^{535}$ EIZIRIK (1998, Regime..., p. 103).

${ }^{536}$ A saber, <www.cvm.gov.br>.

537 "O $\$ 7^{\circ}$ do art. 11 estabelece, ainda, que deve ser fixado um prazo para o cumprimento das obrigações assumidas no acordo. No entanto, deixa de mencionar qual seria este prazo. Cabe à CVM regulamentar a matéria: a nosso ver, o prazo deve ser curto, não superior a seis meses, posto que o instituto do termo de compromisso visa agilizar o processo sancionador". EIZIRIK (1998, Regime..., p. 104).

${ }^{538}$ Pagamentos à CVM ou a terceiros já identificados devem ser imediatos. Medidas que dependam de outras providências, como a identificação de investidores lesados (com publicação de edital ou postagem de ofícios às bolsas de valores) certamente tomam mais tempo, assim como a realização de assembleias ou outros
} 
administrativos - efeito gerado pela celebração dos acordos - perdurar até o fim do prazo previsto para o adimplemento das obrigações compromissadas ${ }^{539}$.

Sobre o parcelamento das obrigações de pagamento à Comissão, que representam parte significativa dos compromissos propostos e celebrados, cumpre informar que não foi identificado termo de compromisso com previsão de pagamento parcelado, dos valores entregues à autarquia, como condição para aceitação das propostas ${ }^{540}$.

Solução diferente apresenta o artigo 187 do RI-CADE, permitindo à autoridade aceitar pagamentos de forma parcelada, os quais serão corrigidos pela taxa do Sistema Especial de Liquidação e Custódia (SELIC), divulgada pelo BCB. Interessante notar que tais pagamentos são contribuições ao Fundo de Direitos Difusos, e não diretamente a prejudicados pela conduta objeto do acordo. Assim, parece fazer sentido, como incentivo à celebração dos termos de compromisso entre a CVM e os agentes por ela fiscalizados, que no caso de indenização a terceiros sejam pagas imediatamente, e no caso de pagamentos à CVM possam ser objeto de parcelamento, em circunstâncias excepcionais.

Justifica-se a necessidade de intervalos breves pois, somente após o cumprimento do pactuado ou o final do prazo estabelecido para adimplemento das obrigações, podem ser adotados os próximos passos, consistente no arquivamento do processo em relação aos compromitentes pontuais no cumprimento de suas obrigações, ou

eventos societários dos quais dependa alguma obrigação, mas deve ser claro o empenho do compromitente para satisfazer o pactuado da forma mais breve possível.

${ }_{539}$ Artigo $2^{\circ}$ da D. CVM 390/01.

${ }^{540}$ Conforme se verifica, v.g., (i) na ata da Reunião do Colegiado de 23 de fevereiro de 2012, em que se recusou proposta formulada por acusado no Processo Administrativo Sancionador n. RJ 2011/7383: "O Colegiado, no entanto, entendeu não ser conveniente e oportuna a aceitação da proposta, por entender que não há que há [sic] precedentes na CVM que justifiquem a excepcionalidade de acolher o pedido de parcelamento.", (ii) no Parecer do Comitê de Termo de Compromisso de 9 de novembro de 2011 a respeito de proposta apresentada no Processo Administrativo Sancionador CVM N. 30/05: "Face à inexistência, em sede de termo de compromisso, de precedentes de parcelamento em pagamento de indenização a terceiros, o Comitê entende pela necessidade de um indicativo do Colegiado a esse respeito, consoante poder discricionário que lhe é conferido pela Lei $\mathrm{n}^{\circ} 6.385 / 76$ ". (no qual as propostass foram rejeitadas pelo Colegiado por outros fundamentos, sem avaliação da possibilidade de parcelamento de pagamentos), e (iii) no Parecer do Comitê de Termo de Compromisso de 16 de maio de 2012, a respeito de proposta apresentada no Processo Administrativo Sancionador CVM n. 2011/3823: "Inobstante a percepção de que o Colegiado não vem acolhendo particularidades quanto à forma de pagamento de propostas de Termo de Compromisso, o Comitê decidiu - no caso específico - acolher as pretensões de pagamento com carência de 6 (seis) meses no que se refere à proposta do Sr. [Acusado], contados da publicação do Termo no Diário Oficial da União, e de parcelamento no que se refere às propostas de [Acusados]. O Comitê depreende que a finalidade preventiva do instituto permanece preservada e que as propostas aparentam suficientes para desestimular a prática de condutas assemelhadas." (sendo, em reunião de 19 de junho de 2012 as propostas rejeitadas pelo Colegiado, essencialmente pelo motivo já referido, de inexistir economia processual pois apenas parte dos acusados ter oferecido proposta, e por entender que "o processo deve ser levado a julgamento em relação a todos os acusados, tendo em vista que a decisão poderá orientar as práticas do mercado em casos semelhantes"). 
a retomada do procedimento administrativo anteriormente suspenso e a execução judicial do termo, no caso de falha na satisfação das ações pactuadas.

O cumprimento das obrigações deve ser atestado pela Superintendência da CVM relacionada à área correspondente. Assim, exemplificativamente, obrigações de pagamento a companhias devem ser confirmados pela Superintendência de Relações com Empresas, pagamentos à Comissão devem ser verificados pela Superintendência Administrativo-Financeira ${ }^{541}$, entre outras ${ }^{542}$.

\subsubsection{Arquivamento: coisa julgada administrativa}

A celebração do acordo não assegura o arquivamento do acordo administrativo em relação ao proponente, mas apenas a suspensão do feito pelo prazo necessário ao adimplemento das obrigações pactuadas.

Após a confirmação do cumprimento de todas as obrigações contraídas no termo de compromisso por uma (ou mais) Superintendência(s) da Comissão, a Diretoria Colegiada delibera pelo arquivamento definitivo do procedimento administrativo de maneira integral, caso a totalidade dos acusados tenha cumprido com o pactuado ${ }^{543}$, ou em relação aos administrados que tenham firmado e atendido às condições do acordo, com o seguimento do processo administrativo sancionador em relação aos demais.

Destaque-se inexistir previsão expressa, seja na Lei 6.385/76, na D. CVM 390/01 ou na D. CVM 538/08, a respeito do arquivamento do processo administrativo sancionador que tenha sido objeto de termo de compromisso. A solução procedimental adotada pelo Colegiado mostra-se coerente e razoável, pois seria inútil a manutenção da suspensão quando o pactuado entre CVM e administrado tenha sido cumprido.

A previsão de arquivamento após a homologação do cumprimento das obrigações pela Diretoria Colegiada usualmente é prevista no texto dos acordos

\footnotetext{
${ }^{541}$ Conforme pode ser identificado no Termo de Compromisso firmado em 17 de outubro de 2011, originado de proposta formulada nos autos do Processo Administrativo CVM n. RJ 2011/1323.

${ }^{542}$ Há registro de obrigações atestadas pela Superintendência de Investidores Institucionais (Termo de Compromisso firmado em 28 de agosto de 2007, relacionado ao Processo Administrativo Sancionador CVM n. RJ 2005/8472), Superintendência de Registro de Valores Mobiliários (Termo de Compromisso firmado em 12 de abril de 2010, relacionado ao Processo Administrativo Sancionador CVM n. RJ 2008/10302), Superintendência de Relações com Investidores Institucionais (Termo de Compromisso firmado em 28 de agosto de 2007, relacionado ao Processo Administrativo Sancionador CVM n. RJ 2005/8472), Superintendência de Relações com o Mercado e Intermediários (Termo de Compromisso firmado em 31 de maio de 2007, relacionado ao Processo Administrativo Sancionador CVM n. SP 2005/173), Superintendência de Fiscalização Externa (Termo de Compromisso firmado em 23 de abril de 2009, relacionado ao Processo Administrativo Sancionador CVM N. 27/05).

543 "Satisfeitas as condições acertadas no termo de compromisso, o processo administrativo será extinto, sem que tenha havido aplicação de penalidade ao acusado ou indiciado". Parecer/CVM/PJU/005, de 10 de março de 1998
} 
administrativos, que em alguns $\operatorname{casos}^{544}$ especifica (desnecessariamente) ser tal arquivamento "sem julgamento de mérito".

Registre-se que, naturalmente, inexiste possibilidade de retomada do mesmo procedimento administrativo, seja perante a CVM, seja em grau de recurso ao CRSFN. Sobre a necessidade de observância e vinculação da administração pública aos acordos, GRAU e FORGIONI (2005, p. 241) explicaram que "é defeso à Administração, por ato de vontade seu, afastar ou suprimir os efeitos de Compromisso de Cessação que efetivamente celebrou. E não pode fazer seja porque, com isso, cruzaria a fronteira da legalidade, seja porque, assim, desrespeitaria o dever de boa-fé pelo qual está vinculada”.

\subsubsection{Inadimplemento}

O inadimplemento, quase desnecessário dizer, não acarreta a extinção do compromisso $^{545}$. Exatamente porque não há renúncia ao poder punitivo. Na eventualidade de inadimplemento (ainda que parcial) do pactuado entre particular e a CVM, o procedimento deverá ser reiniciado no ponto em que fora suspenso.

O parágrafo $8^{\circ}$ da Lei 6.385/76, parafraseado pelo artigo $6^{\circ}$ da D. CVM 390/01, estabelece a imediata retomada de procedimento suspenso, ao não ser satisfeita a totalidade das obrigações pactuadas com a CVM.

Além do reinício doa apuração administrativa, a Lei 6.385/76 traz outra consequência. Pela redação vigente desde 1997 e até outubro de 2001 (após a D. CVM $390 / 01$, portanto), poderia ser argumentado que o inadimplemento acarretaria crime de desobediência, o que foi suprimido por alteração à Lei 6.385/76, operada em 2001.

\subsubsection{Crime de desobediência (vigente até 2001)}

O cabimento da aplicação da desobediência, prevista no artigo 330 do Código Penal (Decreto-Lei n. 2848, de 7 de dezembro de 1940), foi questionada de forma

\footnotetext{
${ }^{544}$ Exemplifcativamente, o termo de compromisso firmado por uma sociedade e um administrador acusados no âmbito do Inquérito Administrativo RJ 2003/3972: “[...] 2.8 Ao término do prazo fixado na cláusula 2.7 acima, e desde que constatado pela CVM o estrito cumprimento pelos COMPROMITENTES das cláusulas e condições ajustadas no presente TERMO DE COMPROMISSO, o Inquérito Administrativo CVM $\mathrm{N}^{\circ} \mathrm{RJ}$ 2003/3972 será arquivado, sem julgamento de seu mérito".

545 "Assim, verificada a violação de obrigação constante do compromisso e afastada interpretação que pudesse descaracterizar tal violação, é de se concluir ainda que (i) as disposições constantes do compromisso permanecem vigentes e devem ser efetivadas. [...] Não há qualquer justificativa, lógica ou jurídica, para reputar que o compromisso de cessação tivesse deixado de vigorar". GRINOVER, 2008, pp. 97-98, em parecer a respeito do inadimplemento de compromisso firmado no âmbito concorrencial, mas cujas observações são plenamente aplicáveis aos acordos celebrados no contexto do mercado de valores mobiliários.
} 
ampla $^{546}$, inclusive existindo argumentos defendendo a atipicidade, em relação à previsão criminal referida, do comportamento de inadimplemento do termo de compromisso $^{547}$. Inexistiria, no caso dos termos, ordem da administração que, não atendida, caracterizaria a conduta punível, mas mero descumprimento de acordo que, por sua natureza negocial, seria apenas passível de execução ${ }^{548}$.

Considerando a mudança legislativa, com a supressão da previsão de crime pelos compromitentes que não honrem o acordado, parece estar revogado o parágrafo único do artigo $6^{\circ}$ da D. CVM 390/01, determinando que a CVM comunique ao Ministério Público o descumprimento de acordos para adoção das medidas cabíveis no contexto criminal. Seguindo tal procedimento, deve ser expedida apenas uma comunicação ${ }^{549}$.

Não parece útil discutir ${ }^{550}$ se a previsão de tipificação era suficiente para minimizar os casos de descumprimento de termos de compromisso ou não, ou se melhor seria prever multa pecuniária em tais casos, pois a quantidade de casos de inadimplemento mostra-se reduzida a apenas um exemplo, atestando a efetividade e a disposição dos administrados em dar cumprimento aos termos.

Não há, para os acordos com a CVM, previsão de multa por descumprimento. Considerando a discricionariedade da administração e a inexistência de vedação expressa $^{551}$ à pactuação de multa em caso de inadimplemento pelo compromissário, parece ser possível a inclusão de cláusula com tal conteúdo. Tendo em vista o reduzido histórico de descumprimento dos termos celebrados com a CVM, não se apresenta a multa como

\footnotetext{
${ }^{546}$ Entre os quais SALLES (1997, p. 114); EIZIRIK (1998, Reforma..., p. 105).

547 "No que tange aos efeitos do inadimplemento das obrigações constantes no termo pelo compromitente, não se pode concordar com a subsunção, em tese, da referida conduta ao tipo previsto no art. 330 do Código Penal, 'crime de desobediência', conforme previa a redação anterior do $\S 7^{\circ}$ do art. 11 da Lei $n^{\circ} 6.385 / 76$. Com efeito, a celebração do compromisso não pode configurar a um só tempo ônus do administrado e ordem proferida pela Administração Pública. Parece, assim, acertada a alteração do referido $\S 7^{\circ}$ pela Lei $n^{\circ}$ 10.303/2001, para suprimir referida previsão”. TANJI (2009, pp. 100-101).

${ }^{548}$ EIZIRIK (1998, Reforma..., p. 105).

549 Conforme registrado no relatório do Inquérito Administrativo CVM n. 04/99, único processo administrativo retomado por inadimplemento de termo de compromisso, até meados do ano de 2012, em que a Diretora Norma Parente registrou que "Em reunião realizada em 20.06.2001, por considerar descumprida a obrigação de realizar oferta pública para fechamento de capital da [Companhia] assumida no termo de compromisso, o Colegiado decidiu retomar o andamento do inquérito e comunicar o fato ao Ministério Público, uma vez que o descumprimento da obrigação assumida caracterizava, à época, crime de desobediência nos termos do artigo 11, parágrafo $7^{\circ}$, da Lei no 6.385/76 (fls. 2444 e 2445)".

550 " $\mathrm{Na}$ realidade, tipificar como crime de desobediência não solucionava os problemas advindos do descumprimento do acordo. Dever-se-ia ter previsto, nessa hipótese, a indicência de multa diária, tal como ocorre no direito antitruste [...]". CARVALHOSA e EIZIRIK (2002, p. 525).

${ }^{551}$ A Lei 6385/76 e a D. CVM 390 são silentes em relação à multa, diferentemente do que ocorre com a Lei 12.529/11, que coloca a previsão de multa em caso de descumprimento como um requisito essencial para o termo, ao lado da obrigação de cessar a conduta e seus efeitos lesivos (artigo 85, parágrafo $1^{\circ}$, item II). Há, também, previsão genérica no artigo 39 do mesmo diploma, estabelecendo multa diária de pelo menos $\mathrm{R} \$ 5.000,00$ (que pode ser aumentada em até 50 vezes) para descumprimento de termos de compromisso, equiparando tal situação à desobediência às decisões do Tribunal Administrativo de Defesa Econômica.
} 
medida essencial à garantia de sucesso da ferramenta, papel desempenhado pela possível retomada do processo administrativo.

\subsubsection{Exequibilidade}

Antes da reforma de 2001, existia dúvida em relação à caracterização do termo de compromisso firmado com a CVM como título executivo extrajudicial, como determinou, de forma expressa, a lei concorrencial da época, em seu artigo 53, parágrafo $4^{\circ}$.

Sugeriu-se ${ }^{552}$ que, para garantir nível superior de segurança à administração, e procedimento mais célere para eventual execução, fossem observadas as formalidades do artigo 585, II, do Código de Processo Civil (especificação de quantia líquida e certa, e celebração acompanhada por duas testemunhas) ${ }^{553}$. Observando tal recomendação, ainda antes da modificação na Lei $6.385 / 76$ pela Lei $10.303 / 01$, pela qual o termo de compromisso passou a ser título executivo judicial, a D. CVM 390/01 ${ }^{554}$ já exigia que os termos que instrumentalizavam os acordos fossem firmados por duas testemunhas, além do Presidente da CVM e das partes interessadas.

Após a reforma na Lei 6.385/76, o termo compromisso passou a ser título executivo independentemente das formalidades das quais esteja revestido ${ }^{555}$. Ampliou-se a discussão, embora restrita ao campo teórico (pela inexistência de casos em que necessária a execução), a respeito da legitimidade de a CVM pleitear pagamento em nome de terceiros beneficiários de ressarcimento, por ser a autarquia parte no termo. A doutrina entende que a Comissão pode reclamar judicialmente exclusivamente pagamentos devidos a ela própria, cabendo aos terceiros credores do ressarcimento cobrar o respectivo pagamento ${ }^{556}$.

\subsubsection{Retomada do procedimento}

\footnotetext{
${ }^{552}$ Entre outros, EIZIRIK (1998, Reforma..., p. 104).

${ }^{553}$ Sobre o tema, DINAMARCO (2009, pp. 303-306).

${ }_{554}$ Artigo $3^{\circ}$, parágrafo $1^{\circ}$, da D. CVM 390/01.

${ }^{555}$ Trata-se de benefício potencial em relação à efetividade dos termos, o qual segue pendente de utilização inaugural. Em caso de necessidade, a Comissão "estará ainda, de pronto, munida de título executivo extrajudicial contra o particular”. DUBEUX (2006, p. 100-101).

556 “O termo de compromisso, como título executivo, pode ter como objeto obrigação de fazer ou não fazer, ou estabelecer o pagamento de indenização ou sanção condenatória (quantia certa). Na hipótese de descumprimento de obrigação de fazer ou não fazer prevista no termo de compromisso, caberá à Comissão de Valores Mobiliários ingressar com a ação de execução, sendo-lhe facultado, ainda, dar continuidade ao procedimento administrativo que fora interrompido com a assinatura do compromisso. [...] Não poderá, ademais, a Comissão de Valores Mobiliários promover ação de execução, quando houver o descumprimento de obrigação de pagar os prejudicados, tendo em vista que a lei não lhe outorgou a possibilidade de atuar como substituto processual. Dessa forma, somente poderá ingressar com a ação executiva o prejudicado a quem efetivamente caberia o pagamento da indenização fixada no termo de compromisso". CARVALHOSA e EIZIRIK (2002, pp. 527-528).
} 
A retomada do procedimento administrativo sancionador não assegura a aplicação de penalidades, como uma leitura superficial do parágrafo $8^{\circ}$ do artigo 11 da Lei 6.385/76 pode revelar. O inquérito ou processo administrativo deverá voltar a tramitar do ponto em que foi paralisado, quando da suspensão decorrente da assinatura do acordo, existindo aplicação de penalidades apenas quando e se o acusado for considerado culpado, ao final do processo de apuração de sua responsabilidade, observados os recursos administrativos cabíveis e a possibilidade de questionamento judicial da decisão.

Ainda que "indiciados que descumpram as disposições a que se submeteram perante a CVM desfrutem de presunção de inocência, ao amparo do artigo $5^{\circ}$, LVII, da

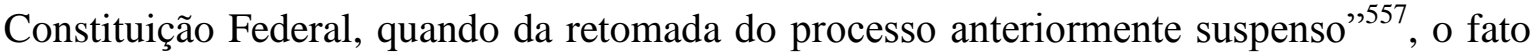
de o acusado não ter honrado termo de compromisso que ele próprio sugeriu não lhe trará benefícios, quando de seu subsequente julgamento.

A Comissão, no início da utilização dos acordos como ferramenta para implementação de política regulatória, manifestou preocupação com relação à repercussão de eventuais descumprimentos, que poderiam atacar a credibilidade não só dos termos de compromisso, mas da própria autarquia ${ }^{558}$.

Para garantir que a celebração de termos de compromisso como medida procrastinatória fosse definitivamente desencorajada, evitando embaraços ao exercício do poder de polícia da CVM, sugeriu-se " $^{559}$ "fazer constar de todas as minutas de termo de compromisso a prévia e expressa renúncia do compromissário ao direito de recorrer da decisão de mérito que, eventualmente, venha a ser proferida no processo administrativo cujo curso tenha sido retomado" em casos de inadimplemento dos termos. Não parece,

\footnotetext{
${ }^{557}$ Parecer PJU 5/98, que erroneamene profetizou que "Esta norma reduz sensivelmente a eficácia do instituto, pois não compele o acusado ou indiciado à obediência às disposições constantes do termo de compromisso". Aparentemente a ausência de multa e de confissão quanto à matéria de fato, a última em decorrência da manutenção de presunção de inocência, não influenciaram negativamente na "eficácia" do termo de compromisso. Imagina-se ser possível tal resultado dever-se seguintes fatores: os termos de compromisso são vantajosos ao agente, que prefere adimpli-lo e garantir o arquivamento do caso, evitando o risco de ser retomado o processo administrativo suspenso, e/ou o compromitente deseja evitar agravamento dos prejuízos reputacionais sofridos perante o mercado, que poderiam ser causados pelo inadimplemento dos termos, vez que deve é objeto de divulgação.

558 " "[...] o descumprimento das obrigações assumidas perante a CVM possui, de per se, grande potencial lesivo, uma vez que representa um desafio à autoridade que é confiada a esta autarquia, caracterizando uma conduta de insubordinação que, em última instância, repercutirá de forma negativa para a atividade administrativa desenvolvida pela CVM". Parecer CVM/PJU/5/98.

${ }^{559}$ Parecer CVM/PJU/6/1998.
} 
contudo, que tal sugestão seja necessária e razoável (podendo desestimular a celebração dos termos) ainda que possa ser argumentada sua compatibilidade com o sistema ${ }^{560}$.

Tal medida não foi adotada e, como resultado atual de eventual inadimplemento de termos de compromisso, há a sujeição do administrado à execução judicial do termo de compromisso e a retomada do procedimento administrativo suspenso.

Cabe questionar se é possível (ou adequado) que, simultaneamente, haja uma decisão no processo administrativo e o particular seja compelido judicialmente a cumprir o acordo. Uma situação como essa poderia gerar cenários inusitados: absolvição no julgamento administrativo, simultaneamente à ordem judicial para adimplemento do termo de compromisso, com reflexos patrimoniais; ou condenação administrativa a uma pena pecuniária (que pode ser mais branda ou mais gravosa do que os termos do acordo) e, concomitantemente, ser obrigado a indenizar a $\mathrm{CVM}^{561}$, por conta de decisão judicial no âmbito da execução.

Parecem existir argumentos sólidos tanto para a defesa da posição da Comissão, no sentido de as situações acima estarem harmonizadas com o arcabouço normativo, quanto do ponto de vista do administrado, desejando impedir que tal conjuntura se confirme.

A primeira poderia ser fundamentada na própria Lei 6.385/76, cujo artigo 11 , parágrafo $8^{\circ}$, determina obrigatoriamente a continuidade do procedimento administrativo, caso o compromitente não cumpra o pactuado "no prazo". Assim, considerando a natureza vinculada da atividade administrativa, a CVM estaria obrigada a retomar o procedimento sancionador ao não ser adimplida a obrigação no prazo combinado e, cumulativamente, executar o termo de compromisso, caso tenha legitimidade ${ }^{562}$.

O resultado de uma medida não depende daquele obtido com a outra, inclusive porque os fundamentos seriam diversos: a retomada é para apuração das condutas sujeitas à investigação, considerando a tarefa fiscalizadora e punitiva da Comissão; e a execução do acordo decorre do inadimplemento do próprio acordo, que seria novo fato, autônomo em relação ao primeiro.

\footnotetext{
560 “A renúncia ao direito de recorrer, embora não cogitada no âmbito do processo penal, é expressamente disciplinada pela legislação processual civil, independendo da aceitação pela outra parte (CPC, art. 502), pelo que se trata de direito plenamente disponível. Sua inserção no termo de compromisso, portanto, não configura violação do princípio da ampla defesa, assegurado pela Constituição Federal". Parecer/CVM/PJU/006, de 10 de março de 1998.

${ }^{561}$ Considerando a tendência de pagamentos à CVM exposta no item 4.1.1.2 acima.

562 Como observado anteriormente, há casos em que parece ser a CVM parte legítima para pleitear a execução do termo, e outros em que cabe a terceiros tal reclamação. Inclusive um mesmo termo pode conter obrigações diversas, e a CVM pode ser legitimada a solicitar apenas parte do todo compromissado.
} 
Já o administrado poderia argumentar que o julgamento administrativo e o acordo substitutivo, como o próprio nome indica, não devem coexistir. Caso a CVM decida pela execução judicial e esta tenha sucesso, estaria satisfeito o interesse público, objeto de análise de conveniência e oportunidade quando da celebração do termo. Satisfeito o pactuado (independentemente de ser obtido no prazo, com atraso ou exclusivamente após a Comissão recorrer ao apoio judicial ${ }^{563}$ ), a administração nada mais poderia exigir do compromitente. Ou que, alternativamente, ao ser retomado o processo suspenso, a CVM desistiria do termo de compromisso, não sendo compatível exigir que as obrigações contratadas sejam satisfeitas pelo particular, com a retomada da apuração da conduta pela própria CVM. Considerando haver certa bilateralidade na celebração do termo, pelas concessões mútuas que o caracterizam ${ }^{564}$, poder-se-ia argumentar a configuração de caso de exceção de contrato não cumprido ${ }^{565}$.

Por outro lado, e aqui definindo inclinação ao entendimento da existência de posição aparentemente mais correta, o particular tinha ciência da possibilidade de o procedimento ser retomado em caso de inadimplemento, assim como, ao firmar o acordo, era de seu conhecimento a exequibilidade do termo, inclusive prevista expressamente na Lei $6.385 / 76$, desde 2001. Era previsível, portanto, que ambas as medidas poderiam ser adotadas, o que inclusive é um desestímulo para o inadimplemento dos termos celebrados com a Comissão.

Importante referir que não há registro, no único caso de inadimplemento de termos de compromisso (Inquérito Administrativo CVM n. 04/99), de execução do termo de compromisso, embora a ele tenham se seguido “(i) julgamento do feito pelo Colegiado da CVM com a aplicação de penalidades administrativas; e (ii) ajuizamento de ação coletiva pelo MPF em face dos então compromitentes, na qual a CVM figura como assistente da parte autora (autos $\mathrm{n}^{\mathrm{o}}$ 2004.61.00.019427-5, em trâmite perante o Juízo da $5^{\mathrm{a}}$ Vara Cível da Subseção Judiciária da Capital do Estado de São Paulo)" ${ }^{\text {„566. }}$.

\footnotetext{
${ }^{563}$ Caso em que, além da obrigação pactuada, caberia ao compromitente inadimplente ressarcir à CVM as despesas e custas processuais incorridas, bem como recompor valores devidos especificados no termo de compromisso, com o acréscimo de juros e correção monetária.

${ }^{564}$ Conforme abordado no item 4.1 supra.

565 Disciplinado pelo artigo 476 do Código Civil: "Nos contratos bilaterais, nenhum dos contratantes, antes de cumprida a sua obrigação, pode exigir o implemento da do outro."

566 TANJI (2009, p. 101).
} 


\section{DELIBERAÇÃO CVM N. 486/05}

A D. CVM 486/05 alterou a D. CVM 390/01 para instituir o Comitê de Termo de Compromisso, e ajustar o prazo para proposta dos termos de compromisso, em tendência de flexibilização que, mais adiante, se intensificou na D. CVM 657/11 ${ }^{567}$.

No presente item é verificado o escopo do edital que propôs audiência pública para contribuições sobre o tema, e questões relacionadas à composição e funcionamento do Comitê de Termo de Compromisso.

Antes, porém, é digno de nota o voto proferido pela Diretora Norma Parente em 23 de novembro de 2004, no Processo CVM n. RJ 2003/12433, no qual o Colegiado da autarquia avaliava a melhor forma de modificação da disciplina normativa do tema, em período antecedente à audiência pública para tratar da alteração à D. CVM 390/01.

Retomando a discussão do Processo CVM RJ n. 2003/0818, cujo objeto era o pedido de revisão do artigo $8^{\circ}$ da D. CVM 390/01 e a flexibilização do momento de apresentação da proposta de acordo ${ }^{568}$, a Diretora apresentou série de sugestões à redação da Deliberação original então vigente, entre as quais é possível destacar (i) a exclusão do prazo contado a partir da intimação para apresentação de proposta de termo de compromisso, ficando os administrados autorizados a submeter proposta de acordo a qualquer tempo; (ii) adoção do "momento de sua apresentação, tendo em vista o estágio de desenvolvimento do processo administrativo" como um critério para exame da proposta de acordo, em adição aos constantes do caput do artigo $9^{\circ}$ da D. CVM 390/01 ${ }^{569}$; (iii) estabelecimento de alguns fatores que necessariamente deveriam ser objeto de análise pela Comissão, em cada caso concreto: (a) intenção da parte interessada em manter-se leal ao compromisso; (b) consciência, pela parte interessada, de que sua conduta desperta legitimamente suspeitas de infração à lei e à regulamentação da CVM, revelada por sua disposição a efetuar à CVM um pagamento; (c) natureza da pretensa violação e uma possível reincidência pela parte interessada naquela possível infração; (d) interesses dos investidores; (e) possibilidade de se alcançar, com a celebração do termo de compromisso, uma solução para o conflito mais rápida que se fosse adotado o procedimento administrativo apropriado; e (f) eficácia dos remédios que seriam normalmente aplicados, se fosse comprovada a violação.

\footnotetext{
${ }^{567}$ Sobre o tema, v. item 4.1.2.1.

${ }^{568}$ Tratado no item 4.1.2.1.

${ }^{569}$ Quais sejam, oportunidade e a conveniência na celebração do compromisso, a natureza e a gravidade das infrações objeto do processo, os antecedentes dos acusados e a efetiva possibilidade de punição, no caso concreto.
} 
Entendeu a Diretora Norma Parente que tais modificações "aumentariam certamente a relevância do instituto", tornando-o mais célere e acessível e menos rigoroso, aumentando o seu uso. Segundo o raciocínio da Diretora, o emprego correto da ferramenta dos acordos substitutivos evita (ou pelo menos minimiza) os efeitos prejudiciais causados à sociedade por infrações, quando em comparação com os processos administrativos sancionadores, pela sua agilidade em promover "com maior eficiência a correção de irregularidades praticadas no mercado de valores mobiliários, uma vez que é mais fácil atingir os objetivos pretendidos quando se tem a adesão do infrator".

A Comissão de Valores Mobiliários, porém, não acatou as sugestões da Diretora, promovendo consulta pública sugerindo quantidade bastante inferior de mudanças, mais moderadas.

\subsection{Alterações implementadas}

Em 6 de maio de 2005 a Comissão de Valores Mobiliários veiculou o Edital de Audiência Pública n. 09/2005 tratando quase que exclusivamente da criação do Comitê de Termo de Compromisso, encarregado de preparar e encaminhar ao Colegiado, em até 30 (trinta) dias, parecer sobre as propostas recebidas. Tal órgão, que seria composto por pelo menos 5 (cinco) Superintendentes da CVM, nos casos em que entendesse pertinente, poderia negociar as condições dos Termos de Compromisso apresentados com as partes proponentes, por até 60 (sessenta) dias ${ }^{570}$.

A Comissão, no edital, explanou acreditar que a mudança aperfeiçoaria o procedimento então existente, desincumbindo os Diretores da negociação das propostas, com o fim de "reforçar o seu distanciamento e a sua independência no momento de um eventual julgamento do caso" e proporcionar "maior eficiência na condução das propostas apresentadas, favorecendo, com isso, a rapidez no julgamento dos processos administrativos sancionadores". Adicionalmente, o Comitê, com o envolvimento de representantes de várias áreas da autarquia, conferiria maior legitimidade à ferramenta ${ }^{571}$.

\footnotetext{
${ }^{570}$ As bases para constituição e atuação do Comitê não foram alteradas após a audiência pública, tendo sido realizado apenas um ajuste com relação ao prazo para elaboração do parecer, nos casos em que, a despeito das negociaç̃os empreendidas, não houver nova proposta pelo administrado.

571 "A propósito, vale mencionar que a criação, no ano de 2005, do já referido Comitê de Termo de Compromisso - integrado por diversos Superintendentes da CVM, bem como pelo Procurador-Chefe da Autarquia, que também ali realiza o controle da legalidade - demonstrou enfaticamente aos participantes do mercado mobiliário a especial importância que a CVM confere a esse tipo de solução antecipada e consensual dos procedimentos administrativos de natureza sancionadora e aos aspectos de oportunidade e conveniência que devem ser considerados para a celebração de termos de compromisso." WELLISCH e SANTOS, 2009 (p.6).
} 
Apesar de o relatório da audiência pública não estar disponível para consulta, prejudicando em parte a presente análise, pela comparação entre a minuta de normativo submetida às contribuições do mercado e a D. CVM 486/05, conforme aprovada pela Diretoria Colegiada em 10 de agosto de 2005, é possível notar uma única alteração: a inclusão do parágrafo $4^{\circ}$ ao artigo $7^{\circ}$ para, em casos excepcionais, por proposta do Diretor Relator de processo administrativo sancionador, ser efetuada análise de proposta de termo de compromisso submetida após o prazo previsto na regra geral, fosse tal medida determinada pelo interesse público e, adicionalmente, restasse demonstrada mudança de situação de fato justificadora, existente na época do prazo não observado ${ }^{572}$.

\subsubsection{Instituição do Comitê de Termo de Compromisso}

A repercussão sobre a criação do Comitê foi, com justiça, amplamente positiva $^{573}$. As vantagens de tal medida incluem (i) capacitação de grupo de servidores, em relação às estratégias e métodos para negociação, tendo em vista os objetivos da ferramenta do termo de compromisso; (ii) possibilidade de organização de dados e informações que registrem o histórico, o desenvolvimento e a experiência acumulada na atividade, centralizando informações que ficavam esparsas com os Diretores, as quais poderiam ser desperdiçadas com a substituição natural dos membros do Colegiado; (iii) possibilidade de desenvolvimento de estudos e análise do comportamento do mercado em relação aos termos, de forma bastante ágil, para aprimoramento do enforcement; e (iv) monitoramento e análise de práticas de outros mercados, tanto internacionais quanto em outras áreas da administração pública local, para constante aprimoramento da ferramenta.

A ideia de otimizar a análise e negociação das condições dos acordos com administrados com o fim de tornar o processo mais organizado e ágil, motivadora da criação do Comitê de Termo de Compromisso, foi posteriormente adaptada pelo CADE. O Regimento Interno da Autarquia, desde $2009^{574}$, prevê a constituição de uma Comissão de

\footnotetext{
${ }^{572}$ Conforme relatado no item 4.1.2.1, incluindo a posterior alteração do mesmo parágrafo.

${ }^{573}$ EIZIRIK (2008, pp. 360-361) afirmou que "Deve ser destacado que a implementação do Comitê de Termo de Compromisso conferiu maior celeridade à analise das propostas, vindo assim a colaborar para que sua celebração cumpra a finalidade precípua a que se destina, qual seja, a de evitar, mediante acordo firmado, o prolongamento indesejável dos conflitos instaurados" e que "A criação, em 2005, de um Comitê composto por superintendentes da CVM, encarregado de apreciar as propostas de termos de compromisso apresentados pelos acusados, revelou-se medida acertada e consetânea com a necessidade de tornar tais procedimentos mais céleres e técnicos" (2006, p.37). CUEVA (2007, p. 300), por outro lado, ressaltou que "A autolimitação de sua discricionariedade, pela CVM, mediante a criação do comitê de termo de compromisso, tende inegavelmente a aumentar a transparência d procedimento, bem como a definir critérios objetivos para a celebração do compromisso".

${ }^{574}$ A Resolução n. 51, de 4 de fevereiro de 2009 alterou os artigos 129-C e 129-D do Regimento Interno do CADE então vigente, para prever a Comissão de Negociação e disciplinar suas atribuições.
} 
Negociação, para auxiliar o Conselheiro-Relator cujos membros são destacados para atuação nas negociações dos termos de compromisso.

\subsubsection{Composição do Comitê}

A Portaria da Presidência da CVM prevista na D. CVM 486/05, baixada em 17 de agosto de 2005 sob o n. 71, regulou "a composição e o funcionamento do Comitê de Termo de Compromisso de que trata o art. $8^{\circ}$ da Deliberação CVM no 390 , de 8 de maio de $2001 \%$.

Além do Superintendente-Geral, a quem cabe a tarefa de coordenação do Comitê, a Portaria previa a participação dos titulares das seguintes superintendências: Fiscalização Externa, Relações com Empresas, Relações com o Mercado e Intermediários, e Normas Contábeis e Auditoria.

Com a criação, em 2008, da Superintendência de Processo Sancionadores ${ }^{575}$, seu titular passou a subscrever os pareceres do Comitê ${ }^{576}$ - como seria de se esperar, considerando a afinidade entre sua área e o objeto das análises e negociações, ainda que não se tenha notícia de novo ato da presidência da Comissão alterando a composição do Comitê.

\subsubsection{Mecânica de funcionamento}

Ao Comitê compete a análise das propostas de termo de compromisso, previamente à sua apresentação ao Colegiado. Conforme visto ${ }^{577}$, o órgão verifica as considerações da Procuradoria Federal Especializada a respeito da proposta submetida pelo interessado e elabora parecer sobre a sua adequação (da proposta), considerando as informações disponíveis no processo administrativo - essencialmente a peça acusatória para verificação das condutas que foram imputadas ao administrado.

Vislumbrando a possibilidade de melhor adequação dos termos, considerando precedentes com características comparáveis que tenham sido aprovados pela Diretoria Colegiada $^{578}$, o Comitê pode efetuar negociação dos termos propostos, como já

\footnotetext{
575 Operada pela Deliberação CVM n. 537, de 4 de março de 2008.

${ }^{576}$ Conforme pode ser notado, por exemplo, já no parecer, datado de 16 de abril de 2008, sobre proposta apresentada no âmbito do Processo Administrativo Sancionador CVM n. RJ 2007/2078.

${ }_{577}^{57 t}$ Item 4.1.2.4 supra.

578 “embora a decisão final compita ao Colegiado, existe todo um trabalho prévio e de cunho opinativo que, além de facilitar o procedimento e agregar-lhe valor, busca imprimir maior uniformidade e previsibilidade na perspectiva dos administrados, por meio de opiniões coerentes, aderentes a precedentes do Colegiado e cada vez mais técnicas e apuradas". WELLISCH e SANTOS $(2009$, p. 6).
} 
apresentado $^{579}$, elaborando a sua proposta final, com base nos critérios que devem pautar a decisão do Colegiado ${ }^{580}$.

A interação entre o Comitê e o administrado é dinâmica, aparentemente existindo verdadeiro diálogo entre ambos, como é possível interpretar do texto do Parecer de 1 de dezembro de 2009, apresentado a respeito de proposta apresentada pelos acusados no Processo Administrativo Sancionador CVM n. RJ 2009/3049:

\begin{abstract}
Em reunião realizada, os proponentes "questionaram sobre a possibilidade de o Comitê reduzir os valores contrapropostos. O Comitê, por sua vez, expôs considerações acerca de suas atribuições, elucidando que o montante sugerido foi baseado nos mais recentes precedentes de Termo de Compromisso com características essenciais similares àquelas contidas no caso concreto, considerando orientação do Colegiado no sentido de que as propostas devem contemplar compromisso tido como suficiente para fins de inibir a prática de condutas assemelhadas, em atendimento à finalidade preventiva do instituto de que se cuida".
\end{abstract}

\title{
10.1.2. Prazo para proposta
}

A despeito do que fora sugerido pela Diretora Norma Parente, no edital da audiência pública foi mantida a restrição de 30 dias após o término do prazo para apresentação da defesa administrativa para o administrado propor a celebração do termo, não tendo sido possibilitado aos agentes do mercado opinar sobre a potencial modificação desse prazo.

A flexibilização, incluída no âmbito da consulta pública - pois inexistente na versão submetida para comentários do mercado - foi admitida para hipóteses excepcionais, nas quais é possível a apresentação de proposta independentemente do momento processual em curso, conforme examinado no item 4.2.1 acima.

\footnotetext{
${ }^{579}$ Item 4.1.2.4.1 supra.

${ }^{580}$ Sobre o tema, itens 4.1.2.5.1 e seguintes.
} 


\section{DELIBERAÇÃO CVM N. 657/11}

Em 7 de fevereiro de 2011, como resultado da Audiência Pública n. 07/10, iniciada 27 de outubro de 2010, foi divulgada a D. CVM 657/11, aprovada pela Diretoria Colegiada em reunião de $1^{\circ}$ de fevereiro.

A audiência foi convocada para discutir uma minuta cujo objetivo principal era alterar a D. CVM 390/01, para “(i) unificar o prazo para apresentação de defesa e de apresentação, pelos interessados, de proposta de termo de compromisso; e (ii) aperfeiçoar as hipóteses em que, excepcionalmente, o Colegiado admite apreciar proposta de termo de compromisso apresentada fora do prazo".

O primeiro item planejava acabar com o prazo adicional de 30 (trinta) dias, contado da apresentação da defesa administrativa, para apresentação da proposta de acordo com a CVM. Já o segundo pretendia adequar a norma às práticas já adotadas pelo Colegiado ${ }^{581}$, ao "eliminar a exigência de modificação da situação de fato existente quando do término do prazo para que se justifique a apreciação da proposta extemporânea", e eliminar também a competência do Relator para apreciação dos casos de proposta apresentada fora do prazo e, apenas quando entender conveniente, submetê-la à Diretoria, para deliberação. A CVM pretendia que tal proposta fosse obrigatoriamente levada à discussão no órgão Colegiado.

Considerando manifestação uníssona dos participantes da audiência pública no sentido contrário à unificação dos prazos, entendendo ser prejudicial tanto à defesa quanto à atenção destacada para a elaboração da proposta de acordo, e afirmando que a celeridade pretendida não recompensaria o ônus imposto aos interessados, a Comissão concluiu pela manutenção da redação então vigente, sem excluir a faculdade de apresentação das propostas em até 30 (trinta) dias após o término do prazo para entrega da defesa administrativa.

Assim sendo, a principal herança da audiência em comento foi uma nova flexibilização do prazo para apresentação da proposta de termo, que passou a ser possível praticamente a qualquer momento, como já vinha sendo conduzido, na prática, pelo Colegiado (ainda que em desacordo à D. CVM 390/01, conforme vigente até então). Anote-se que o relatório da audiência pública não registrou qualquer objeção ou comentário sobre tal mudança.

\footnotetext{
${ }^{581}$ Com a citação, no Edital de Audiência Pública, das decisões proferidas nos Processos Administrativos RJ2009/4744 em 8 de dezembro de 2009 e 21/05 em 15 de dezembro de 2009.
} 


\section{TERMO DE COMPROMISSO E OS AGENTES DE AUTORREGULAÇÃOO}

A autorregulação ${ }^{582}$, cujo papel e importância são reconhecidos há muito pela $\mathrm{CVM}^{583}$, é relevante também em relação ao desenvolvimento e aplicação da ferramenta dos termos de compromisso.

Logo quando da criação dessa ferramenta, com as alterações promovidas pela Lei 9.457/97 à Lei 6.385/76, foi previsto que a CVM regulamentaria a sua aplicação nos procedimentos conduzidos pelas bolsas de valores e entidades do mercado de balcão. A partir da reforma operada pela Lei $10.303 / 01^{584}$, foram incluídos nesse rol as bolsas de mercadorias e futuros e entidades de compensação e liquidação de operações no mercado de valores mobiliários ${ }^{585}$.

A regulamentação ocorre, aparentemente, nos termos do artigo 117, IV, da Instrução CVM n. 461, de 23 e outubro de 2007 (“I. CVM 461/07”), que condiciona a produção de efeitos de procedimentos a serem observados pelas entidades ali disciplinadas (bolsas de valores, bolsas de mercadorias e futuros e mercados de balcão organizado) versando sobre instauração e trâmite de processos administrativos disciplinares, bem como a celebração dos termos de compromisso.

A utilização dos termos de compromisso pelas entidades autorreguladoras parece muito adequada, considerando o próprio objetivo dessas entidades ${ }^{586}$. No curso do tempo, essa ferramenta tem se mostrado bastante útil, também em tal terreno ${ }^{587}$.

\footnotetext{
582 "São duas as espécies de regulação, a hetero-regulação, imposta por agência pública e a auto-regulação, quando as regras são predispostas por integrantes do grupo a ser regulado, ou exercentes da atividade a ser regulada. No mercado de valores mobiliários as duas formas coexistem". SZTAJN (2004, p.138). Sobre o tema, confira-se DIAS (2005) e CALABRÓ (2011).

583 Ainda em 1979, documento elaborado pela própria CVM já informava que a autorregulação poderia colaborar de forma a "reduzir o porte e de tornar mais eficiente a atuação do órgão regulador, já que só poderia ter uma ação sensível, ágil e eficaz, caso duplicasse inúmeras funções desempenhadas por entidades privadas existentes no mercado de valores mobiliários. [...] Por outro lado, na delegação de poderes de normatização e fiscalização, o órgão regulador conserva as competências residuais que lhe permitem evitar possíveis inconvenientes da auto-regulação, como a complacência em relação a assuntos de interesse público, a tendência à autoproteção dos regulados, a leniência na imposição de sanções e atitudes tolerantes, decorrentes do desejo de evitar publicidade adversa aos negócios”. Citado por TANURE (2005, p. 12).

${ }^{584}$ Conforme examinado no item 5 acima.

585 "Dessa forma, na mesma medida em que há delegação de competência para aplicar determinadas sanções administrativas por averiguação de infrações no âmbito da auto-regulação, também foi prevista a delegação de competência para que tais entidades atuem de forma concertada”. PALMA (2010, p. 180).

586 “'As medidas de 'enforcement' adotadas pela estrutura de autorregulação não tem como objetivo a punição em si, mas, sim, a melhoria da estrutura de intermediação, a fim de que sejam evitadas as condutas ilícitas e omercado possa funcionar de maneira regular". CALABRÓ (2011, p. 48). O mesmo autor, (obra citada, pp. 55-56) afirma que "o processo conduzido pela estrutura de autorregulação é disciplinar, no sentido de que sua finalidade é educativa, e não repressiva, visando a melhoria do padrão de conduta [...]. Já o processo conduzido pela CVM é sancionador, no sentido de que sua finalidade é repressiva e punitiva, fundamentada no 'jus puniendi' estatal".
} 


\subsection{Influência da CVM sobre a BM\&FBOVESPA Supervisão de Mercados}

A "BM\&FBOVESPA Supervisão de Mercados - BSM" ("BSM"), antiga “BOVESPA Supervisão de Mercados", é entidade autorreguladora de todos os mercados componentes da BM\&FBOVESPA.

A função disciplinar das bolsas de valores, mais antiga do que a própria Comissão de Valores Mobiliários ${ }^{588}$, posteriormente colocada na condição de "poder disciplinar derivado" ${ }^{, 59}$, para fiscalizar as operações realizadas em seu ambiente, foi prevista pelo legislador ${ }^{590}$ quando da criação do termo de compromisso aplicável aos processos administrativos sancionadores conduzidos pela CVM.

Assim, contemplada no artigo 11, parágrafo 10, da Lei 6.385/76, a possibilidade de celebração de termos de compromisso pela BSM foi regulamentada pelo artigo 46, parágrafo $1^{\circ}$, I, da I. CVM 461/07, para que a ferramenta pudesse ser utilizada nos processos disciplinares conduzidos pela $\mathrm{BSM}^{591}$.

A mecânica de utilização dos termos de compromisso nos processos disciplinares dessa entidade foi objeto de pormenorizado regramento, compreendido entre os artigos 46 e 61 do Regulamento Processual da $\mathrm{BSM}^{592}$, o qual é bastante assemelhado às regras da Comissão de Valores Mobiliários sobre os termos.

Todo o procedimento - desde a adaptação da vedação à utilização em procedimentos administrativos para apuração de infrações relacionadas à "lavagem" de

\footnotetext{
${ }^{587}$ Dados a respeito podem ser encontrados no item 4.4.1.

588 "Um importante capítulo no estudo do direito disciplinar do mercado de valores mobiliários diz respeito à função das Bolsas de Valores, tendo em vista o elenco de penalidades aplicáveis às suas administrações, aos seus membros e às administrações das caixas de liquidação [...] Preexistente à da própria CVM, a função disciplinar das Bolsas de Valores não se sobrepõe, contudo, à da Comissão, de vez que, com a reorganização do sistema de distribuição de valores mobiliários, procedida pela Lei 6.385/76, as Bolsas de Valores, dotadas de 'autonomia' administrativa, financeira e patrimonial, passam a operar sob a 'supervisão' da autarquia, incumbindo-lhes, como órgãos auxiliares desta última, 'fiscalizar' os respectivos membros e as operações nelas realizadas (art. 17).” GUERREIRO (1981, p. 72).

${ }^{589}$ Expressão utilizada pelo Professor GUERREIRO (1981, p. 72). Anote-se que a Lei 6.385/76, em seu artigo $8^{\circ}$, parágrafo $1^{\circ}$, expressamente ressalvou a "competência" das bolsas e entidades de compensação e liquidação com relação aos seus membros e operações realizadas em seus ambientes.

590 "Como muitas vezes existe o poder disciplinar concorrente das Bolsas de Valores, de entidades do mercado de balcão organizado e da Comissão de Valores Mobiliários, defere-se a esta o poder de regulamentar a aplicação do disposto nos $\S \S 5^{\circ}$ a $9^{\circ}$ aos procedimentos por aquelas conduzidos, mediante adição de parágrafo, numerado como §10”. Voto do relator do PL 1.564/96, Luiz Carlos Hauly, reproduzido na Revista de Direito Mercantil n. 105 de 1997, p.172.

591 “As regras sobre a suspensão dos processos administrativos em casos de infrações da legislação sobre mercado de valores mobiliários são estendidas pela reforma aos casos de procedimentos conduzidos pelas Bolsas de Valores e pelas entidades do mercado de balcão organizado, devendo a CVM regulamentar a matéria (art. 11, §10). Observa-se, no caso, de um lado a existência de um poder auto-regulamentador das entidades do mercado (vide art. 17) e, de outro, a fixação de regras sobre o exercício desse poder". VERÇOSA (1998, p. 204).

${ }^{592}$ Aprovado por resolução de 26 de agosto de 2008 e alterado em 16 de julho de 2010.
} 
bens, informação ao acusado a respeito da possibilidade de propor o termo de compromisso $^{593}$, passando pelos requisitos de cessação de conduta e reparação de prejuízos, suspensão do processo enquanto o acordo estiver sendo cumprido, até a notificação de terceiros prejudicados para prestarem informação, sem que assumam condição de parte - funciona da mesma maneira ${ }^{594}$.

A aprovação da proposta depende de deliberação do Pleno do Conselho de Supervisão ${ }^{595}$, que deve utilizar os mesmo critérios adotados pelo Colegiado, nos termos da D. CVM 390/01, para decidir sobre a conveniência e oportunidade de aceitar o oferecido pelo administrado.

O Relatório de Atividades 2011, divulgado pela BSM, evidencia que os termos de compromisso têm sido amplamente utilizados pela autoridade autorreguladora, na condução dos processos administrativos disciplinares. Em 2008, nove acusados celebraram termos de compromisso, entre um universo de doze acusados em processos disciplinares. Em 2009, apenas dois entre 24 acusados não tiveram seus processos encerrados em razão de celebração de acordos substitutivos. No ano seguinte, nove agentes foram intimados a apresentar defesa e apenas dois não firmaram termo de compromisso, ao passo que em 2011, entre 33 acusados, 16 puderam evitar julgamento administrativo, oferecendo o cumprimento de obrigações. O mesmo Relatório observa, adicionalmente, inexistir um registro sequer de descumprimento de termo de compromisso no âmbito da BSM.

Uma das motivações para a celebração dos acordos, em adição às vantagens auferidas pelos signatários dos termos de compromisso firmados com a $\mathrm{CVM}^{596}$, é estabelecida pelo artigo 49, parágrafo $4^{\circ}$, da I. CVM 461/07: um agente que tenha celebrado termo de compromisso em processo disciplinar da BSM pode, caso a Comissão decida investigá-lo pela mesma conduta (na eventualidade de a infração às regras da BSM configurar também infração aos deveres previstos na disciplina da autarquia), pleitear que a obrigação pactuada no termo de compromisso firmado com a BSM seja considerada pela CVM, em eventual celebração de termo de compromisso ${ }^{597}$.

\footnotetext{
593 Artigo 16, parágrafo $2^{\circ}$, do Regulamento Processual.

${ }^{594}$ A única diferença encontrada, em comparação entre as regras da CVM e as da BSM sobre os termos de compromisso, é a possibilidade de o Conselho de Supervisão, após receber a proposta, convocar o proponente para apresentar esclarecimentos escritos a respeito do ofertado, como prevê o parágrafo único do artigo 57 do Regulamento Processual. É possível entender que foi prevista tal medida como alternativa à negociação empreendida pelo Comitê de Termo de Compromisso da CVM, inexistente na dinâmica adotada pela BSM.

595 Artigo 59 do Regulamento.

${ }^{596}$ Relacionadas no item 3.5.2 acima.

597 “[...] vale mencionar que o $\S 4^{\circ}$ do art. 49 da Instrução CVM n 461 , de 23 de outubro de 2007, que disciplina os 'mercados regulamentados de valores mobiliários e dispõe sobre a constituição, organização,
} 


\subsection{Celebração de Convênio entre a CVM e a ANBIMA}

ANBIMA é entidade autorreguladora do tipo voluntária ${ }^{598}$, e desempenha supervisão e fiscalização das atividades de seus associados (que, em parte, também são fiscalizadas pela CVM), e pode aplicar sanções aos infratores de suas normas e códigos, devendo tais condutas serem apuradas em processo próprio.

Em 20 de agosto de 2008, foi firmado convênio "relativo à aplicação de penalidades e celebração de termos de compromisso", entre a CVM e a ANBIMA, então denominada "Associação Nacional dos Bancos de Investimento - ANBID 599 ", visando regular o aproveitamento, por uma entidade, da atividade sancionadora desenvolvida pela outra, além de intercâmbio de dados e informações entre ambas ${ }^{600}$.

A dinâmica de tal aproveitamento, conforme prevista no item 2.1 do acordo entre CVM e o órgão autorregulador, depende de consentimento do investigado ${ }^{601}$. De tal modo, apenas mediante solicitação expressa do indiciado (ou sua autorização) é que poderá ser transmitido a uma entidade signatária do Convênio todo o conjunto de informações relacionadas à penalidade ou acordo substitutivo celebrado com a outra convenente, para que sejam consideradas as medidas já adotadas, no contexto da apuração dos mesmos fatos.

Como resultado, em benefício do administrado, a CVM ou a ANBIMA, “caso julguem pertinente, poderão considerar, para fins de celebração do termo de compromisso

funcionamento e extinção das bolsas de valores, bolsas de mercadorias e futuros e mercados de balcão organizado', em claro prestígio aos princípios da razoabilidade e da proporcionalidade - e em consideração aos deveres e ao trabalho de fiscalização realizado por órgãos auto-reguladores que, por força de lei, atuam como auxiliares da CVM - permite que o investigado requeira que a penalidade que lhe tenha sido imposta, ou a prestação que tenha sido acordada em termo de compromisso celebrado no âmbito da auto-regulação, seja submetida à CVM como base para a celebração do termo de compromisso". WELLISCH e SANTOS (2009, p. 10).

${ }^{598}$ Em contraposição às entidades autorreguladoras obrigatórias, como as bolsas de valores.

${ }^{599}$ Em 21 de outubro de 2009 a ANBID foi incorporada à ANDIMA (Associação Nacional das Instituições do Mercado Financeiro), que teve sua denominação alterada para ANBIMA - Associação Brasileira das Entidades do Mercado Financeiro e de Capitais, conforme registrado no $1^{\circ}$ aditamento ao convênio ora referido, firmado em 25 de maio de 2010, pelo qual foi formalizada a sucessão da ANBID pela ANBIMA em todos os direitos e obrigações decorrentes do referido pacto, e reconhecido pela CVM que "a ANBIMA manteve as atividades de autorregulação e códigos próprios que regulamentam atividades de seus associados, autorregulando atividades que são reguladas pela CVM, podendo instaurar processos e aplicar penalidades no caso de violação de tais códigos", consoante o disposto no item 2, do referido convênio.

${ }^{600}$ Conforme registrado no próprio documento, em sua cláusula primeira: "O objeto do presente Convênio é explicitar conceitos que, com base na legislação vigente, podem ser aplicados tanto pela CVM como pela ANBID no exercício das respectivas atuações disciplinares, precisamente no tocante ao mútuo aproveitamento de termos de compromisso celebrados e de penalidades aplicadas no âmbito das duas instituições, bem como tratar sobre o intercâmbio de informações entre as Convenentes".

${ }^{601}$ De forma assemelhada ao previsto no artigo 49, parágrafo $4^{\circ}$ da Instrução CVM n. 461, de 23 de outubro de 2007. 
requerido"602 e "na dosimetria das penas que pretendam aplicar, o teor do termo de compromisso celebrado, ou a penalidade aplicada, pela outra entidade" ${ }^{, 603}$.

Consequentemente, tal compartilhamento de informações e consideração de medidas adotadas pela outra convenente tende a ser pleiteado pelo investigado, vez que não parece ser possível agravar sua situação, vez que apenações ou compromissos já firmados tendem a minimizar os efeitos de uma segunda análise, pela outra entidade. A reparação de danos sofridos por terceiros, por exemplo, uma vez concluída, pode servir para minimizar os custos de um novo acordo ou mitigar uma nova sanção.

Interessante notar, em benefício do agente sujeito à investigação, que é previsto o resguardo, em qualquer hipótese, da confidencialidade das informações acessadas em razão do Convênio ${ }^{604}$.

O primeiro caso em que o Convênio foi utilizado, para aproveitamento de obrigação compromissada perante uma entidade na análise de proposta de acordo com a outra, ocorreu no âmbito do Processo Administrativo Sancionador CVM RJ2010/17292. Os mesmos acusados haviam acordado com a ANBIMA o pagamento de R $\$ 350.000,00$ (trezentos e cinquenta mil reais) e pleitearam, tempo depois, após instauração do processo sancionador referido, o aproveitamento de tal acordo pela CVM, nos termos do Convênio.

Principalmente por conta da maneira de proceder dos acusados, no entendimento do Comitê de Termo de Compromisso (confirmado pelo Colegiado), “o aproveitamento integral do termo de compromisso firmado entre a [Acusada] e a ANBIMA não se afigurava adequado ao caso concreto, por não se mostrar plenamente satisfatório para o interesse público presente. Isso porque os proponentes, embora cientes da atuação concomitante da entidade autorreguladora e desta CVM, mantiveram-se silentes perante o órgão regulador no que diz respeito à negociação e à celebração em 31.08 .10 do ajuste junto à ANBIMA, indo de encontro à inteligente utilização da sistemática de aproveitamento da atuação autorregulatória, isto é, em contraposição aos benefícios que poderiam efetivamente ter sido alcançados a partir do imediato aproveitamento desse instrumento, inclusive em termos de celeridade, economia processual e eficiente alocação de recursos e esforços por parte da CVM"605.

\footnotetext{
${ }^{602}$ Item 2.2 do Convênio.

${ }^{603}$ Item 2.3 do Convênio.

${ }^{604}$ Item 3.2 do Convênio.

${ }^{605}$ Excerto do Parecer do Comitê de Termo de Compromisso firmado em 22 de novembro de 2011, no âmbito de análise de proposta de termo de compromisso apresentada no Processo Administrativo Sancionador CVM RJ2010/17292.
} 
Ainda no caso, o Comitê propôs a "aplicação de um 'desconto' sobre a quantia inicialmente aventada [...], considerando a presumida boa-fé da proponente, visto se tratar do primeiro caso em que é pleiteado junto à CVM o aproveitamento de termo de compromisso firmado junto à entidade autorregulatória, nos moldes do Convênio celebrado com a autarquia"606.

Fica claro, na análise do caso, que a CVM não concordou com o procedimento adotado, o que efetivamente minimizou os efeitos positivos do Convênio, de otimizar a atuação da Comissão e da ANBIMA. A CVM buscou sinalizar tal descontentamento ao mercado, com o intuito de que, em um caso posterior, a comunicação a respeito do acordo com o órgão autorregulador ocorra ainda na fase de negociação, com o que é possível prever a assinatura de termos conjuntos - entre CVM e ANBIMA - versando sobre as mesmas condutas.

O efeito esperado foi alcançado, já em 2010, com a apresentação de proposta de termo de compromisso por agentes do mercado, ainda antes da instauração do processo administrativo sancionador pela superintendência competente. Em tal pedido, os proponentes informaram a respeito de acordo substitutivo firmado com a ANBIMA, pelo qual haviam se comprometido a pagar um valor total de $\mathrm{R} \$ 500.000,00$ (quinhentos mil reais), e ofereceram à CVM o pagamento de $\mathrm{R} \$ 350.000,00$ (trezentos e cinquenta mil reais) para celebração de acordo apto a arquivar processo sancionador que sequer ainda havia sido instaurado ${ }^{607}$.

A decisão do Colegiado na ocasião, replicando entendimento do Comitê, foi de que "a aceitação da proposta de Termo de Compromisso apresentada não se afigura oportuna, uma vez que a ausência de peça acusatória e a complexidade das irregularidades possivelmente praticadas impossibilitam a emissão de uma opinião segura quanto à conveniência de se firmar termo de compromisso"608.

Posteriormente, em novembro de 2012, verificou-se nova proposta, agora no valor de $\mathrm{R} \$ 775.000,00$ (setecentos e setenta e cinco mil reais), sendo tal oferta recusada pelo Colegiado da CVM, seguindo parecer do Comitê de Termo de Compromisso, que sequer chegou a abrir negociação com os acusados, pois "o Comitê, frente aos elementos ora disponíveis no caso concreto, entende ser inconveniente, em qualquer cenário, a

\footnotetext{
${ }^{606}$ Excerto do Parecer do Comitê de Termo de Compromisso firmado em 22 de novembro de 2011, no âmbito de análise de proposta de termo de compromisso apresentada no Processo Administrativo Sancionador CVM RJ2010/17292.

${ }^{607}$ O qual, oportunamente, veio a receber o número RJ 2012/12660.

${ }^{608}$ Conforme registrado na ata de reunião de 4 de novembro de 2010.
} 
celebração de Termo de Compromisso, considerando notadamente as características que permeiam o caso, tal qual o volume financeiro envolvido, o contexto em que se verificaram as irregularidades imputadas aos proponentes e a especial gravidade das condutas questionadas pela autarquia".

No caso analisado, a apresentação do acordo celebrado com a ANBIMA à CVM não representou benefício efetivo ao administrado, para fins de celebração de termo de compromisso com esta autarquia, embora não seja impossível de se imaginar que a sua situação ficaria ainda mais agravada caso apenas em investigações posteriores (caso essas viessem a existir, naturalmente) chegasse ao conhecimento da CVM a celebração de acordo com a entidade de autorregulação.

Independentemente dos resultados dos casos citados, a atuação em parceria com a ANBIMA é interessante para sinalizar a aceitação, pelos participantes do mercado, do instrumento do termo de compromisso como método alternativo aos processos sancionadores, e demonstra um amadurecimento e consolidação do tema. 


\section{TERMO DE COMPROMISSO E AJUSTAMENTO DE CONDUTA. ATUAÇÃO CONJUNTA DA CVM E MPF}

Visando a formalizar, regular e dar publicidade ao intercâmbio e cooperação nos temas relacionados ao mercado de valores mobiliários, essencialmente para potencializar prevenção, apuração e repressão às práticas lesivas, a Comissão e o Ministério Público Federal ("MPF”) assinaram, em maio de 2008, um acordo denominado "Termo de Cooperação Técnica".

As premissas de tal acordo, em síntese, foram (i) o estágio de desenvolvimento do mercado de valores mobiliários à época, que demandava fortalecimento dos meios de prevenção, apuração e repressão de práticas lesivas a tal mercado e aos participantes; (ii) o fato de que diversas infrações administrativas, apuradas pela CVM, configuram também crimes e/ou infrações contra a coletividade e os investidores difusos, hipóteses nas quais cabe ao MPF ajuizar ações (penais e/ou civis públicas) ${ }^{609}$; e (iii) uma atuação articulada entre a Comissão e o MPF tende a proporcionar maior efetividade à prevenção, apuração e repressão às práticas lesivas ao mercado de valores mobiliários.

É possível dizer que o Termo de Cooperação formalizou e disciplinou a atuação conjunta e o fluxo de informações entre a CVM e o MPF. Isso porque, ainda que não existente documento oficial público versando a respeito de tal parceria, a relação entre a autarquia e o parquet já existia anteriormente, fosse por obrigação legal ou regulamentar de a Comissão informar ao Ministério Público a ocorrência de crimes ou a verificação de indícios de crimes ${ }^{610}$, fosse por atuação conjunta em alguns casos ${ }^{611}$, fosse por "grupo de

\footnotetext{
${ }^{609}$ Com efeito, os três tipos penais previstos no Capítulo VII-B da Lei 6.385/76, apurados mediante impulso do MPF, coincidem com práticas vedadas pelas normas administrativas. No mesmo passo, dois dos três ilícitos (manipulação de mercado e uso indevido de informação privilegiada) também constituem exemplos de fundamentos para ação civil pública por danos aos investidores do mercado, nos termos do artigo $1^{\circ}$ da Lei n. 7.913, de 7 de dezembro de 1989.

${ }^{610}$ Artigo $9^{\circ}$ da Lei Complementar n. 105, de 10 de janeiro de 2001, e artigo 10 da D. CVM 538/08. Sobre o tema, interessante a exposição do Dr. Eli Loria, registrada na p. 42 dos Cadernos Direito GV, Seminário 38 , v. 7, n. 6, nov. 2010: "[...] ao término das investigações e concluindo pelo ilícito, da existência do ilícito, autoria e materialidade, nesse momento em que vai ser expedida a intimação também vai a comunicação ao Ministério Público. [...] já houve época na CVM em que no início da investigação se comunicava. Era inconveniente porque, ao final, você concluía pela não acusação e já estava correndo o processo penal, com aqueles inconvenientes para as pessoas envolvidas. Por outro lado, era pós-julgamento, o que também era inconveniente porque levava muito tempo e já chegava prescrito. [...] Então, hoje, se faz dessa forma: ao formar convicção da existência do ilícito e da autoria, sai a intimação para a defesa e sai um comunicado ao Ministério Público, à Receita, ao Banco Central [...]".

${ }^{611}$ Exemplificativamente: (i) caso de uso indevido de informação privilegiada, apurado administrativamente no Processo Administrativo Sancionador CVM N. RJ 2007-12231 e na ação civil pública autuada sob o n. 2007.5101022852-8 e ação cautelar autuada sob o n. 2007.51014901576, ambas em tramite perante a $6^{\mathrm{a}}$ Vara Federal do Rio de Janeiro, e que foram objeto do primeiro termo de compromisso e ajustamento de conduta celebrado no âmbito do mercado de valores mobiliários brasileiro, celebrado semanas antes da assinatura do Termo de Cooperação Técnica (tendo tal acordo como peculiaridade, em relação aos termos de compromisso
} 
trabalho especializado", criado em 2006, do qual representantes de ambos faziam parte, e a partir do qual reuniões periódicas passaram a ocorrer ${ }^{612}$.

Após a assinatura do Termo, diversos outros trabalhos foram desenvolvidos em conjunto pelo MPF e CVM, com a combinação processo sancionador/ação civil pública ou processo sancionador/ação penal, ocorrendo, em alguns casos, celebração do acordo conjunto entre o acusado, o Ministério Público e a CVM. Sempre abrangendo, em suas tarefas, mais de uma esfera de imputação, em decorrência da mesma conduta.

\subsection{As três esferas em que há repercussão de infração às normas do mercado: penal, civil e administrativa}

A aplicação de sanções administrativas às condutas que caracterizam uma dupla (ou tripla) infração, por desatenderem simultaneamente um mesmo comportamento prescrito por normas de esferas distintas, não inviabiliza a responsabilização penal ou civil que possa ser caracterizada, conforme dispõe o artigo 9 $9^{\circ}$ VI, da Lei 6.385/76: “Art $9^{\circ} \mathrm{A}$ Comissão de Valores Mobiliários, observado o disposto no $§ 2^{\circ}$ do art. 15, poderá: [...] VI aplicar aos autores das infrações indicadas no inciso anterior as penalidades previstas no Art. 11, sem prejuízo da responsabilidade civil ou penal"613.

A fundamentação para a inexistência de restrição à aplicação de diferentes sanções para uma mesma conduta é simples ${ }^{614}$ : tal conduta configura diferentes desobediências a diferentes regras, cada qual motivando uma punição específica, imposta

que versam exclusivamente sobre processos administrativos, a necessidade de apresentação ao juízo federal para homologação, em decorrência da natureza do termo de ajustamento de conduta, que produz efeitos sobre as lides existentes); e (ii) caso de uso indevido de informações privilegiadas, apurado administrativamente no Processo Administrativo Sancionador CVM 10/2008 e civilmente na ação civil pública autuada sob o n. 2007.5101014273-7 e na ação cautelar autuada sob o n. 2007.5101014079-0, ambas em trâmite perante a $15^{\mathrm{a}}$ Vara Federal do Rio de Janeiro (sendo que um dos acusados firmou termo de compromisso e ajustamento de conduta, simultaneamente assegurando a suspensão dos processos em curso, tanto o administrativo quanto as ações, civil e cautelar, embora conste expressamente que "a celebração do presente TAC não impede a instauração ou ajuizamento de procedimentos ou processos no âmbito penal nem afeta ou prejudica qualquer direito de terceiros eventualmente lesados"). Outros exemplos são citados por SANTOS et. al. (2012, pp. 268-274), reapresentando e complementando informações disponibilizadas em WELLISCH e SANTOS (2009, p. 9).

${ }^{612}$ Conforme declaração do Procurador Federal Cláudio Gheventer, em entrevista concedida a Andréa Háfez, publicada no Espaço Jurídico Bovespa em 30 de junho de 2008.

613 “[...] parece não haver dúvida de que a Lei 6.385/76 consagrou a summa divisio da responsabilidade, enfatizando que a punição administrativa a cargo da CVM será imposta em caráter autônomo, independentemente das conseqüências civis ou penais dos atos ilegais ou das práticas não equitativas". GUERREIRO (1981, pp. 64-65).

614 “[...] não se pode perder de vista a diversidade de finalidades entre as regras que impõem as responsabilidades civil e administrativa sancionadora: as primeiras têm por fim a reparação de prejuízos mediante compensações de cunho patrimonial; já as segundas, visam à proteção de determinados bens e direitos mediante a aplicação de sanções contra condutas em seu desfavor”. SILVA (2006, p. 255). 
por autoridade dotada de poderes próprios para tal medida e buscando um determinado fim $^{615}$.

Simples também é a aplicação de tal lógica, nos âmbito administrativo e judiciário $^{616}$. Na sentença da primeira ação penal para apuração do crime tipificado no artigo 27-D da Lei $6.385 / 76^{617}$, o magistrado afastou desde logo o argumento por vezes suscitado, do bis in idem: “a prática do 'insider trading' é considerada criminosa, vindo a sanção penal a se somar às já existentes regras de responsabilização civil e administrativa do 'insider'. Conforme entendimento bastante antigo da doutrina e da jurisprudência brasileiras, a incidência de sanções civis, administrativas e penais não caracteriza 'bis in idem",618.

O mesmo documento cita precedente do Superior Tribunal de Justiça ${ }^{619}$, também versando sobre conduta que configura ponto de intersecção, por ser reprimida em três esferas: penal, administrativa e civil, em que merece destaque trecho da extensa ementa: “[...] Inexiste violação ao princípio do 'ne bis in idem', tendo em vista a possibilidade de instauração concomitante de ação civil pública e de processo administrativo, in casu, perante a SDE - Secretaria de Desenvolvimento Econômico do Ministério da Justiça, para investigação e punição de um mesmo fato, porquanto as esferas de responsabilização civil, penal e administrativa são independentes”.

Há outros casos do mesmo tribunal acerca do tema, em matéria consumerista (confirmação da possibilidade de aplicação de multa administrativa pelo Procon em razão de violação de deveres do fornecedor - revertida a Fundo Estadual de Defesa do Consumidor -, cumulada com pleito de indenização civil, por ressarcimento de perdas e

\footnotetext{
615 “[...] o princípio do non bis in idem [...] veda apenas a dupla apenação em uma mesma esfera jurídica. Assim, como as esferas administrativa e penal são, em tese, independentes, nada impede que uma pessoa seja punida administrativa e criminalmente pela mesma infração". CARVALHOSA e EIZIRIK (2002, p. 501).

${ }^{616}$ Inclusive no exterior. STEINBERG trata do tema, sob o termo parallel proceedings, inclusive citando decisão prolatada nos Estados Unidos a respeito: "Parallel proceedings, that is, concurrent or successive civil proceedings by the SEC (or another administrative agency) and criminal investigation by the U.S Attorney 9or another prosecutorial entity) generally are constitutional. As stated by the Fifth Circuit: 'There is no generally federal constitutional, statutory or common law rule barring the simultaneous prosecution of separate civil and criminal actions by different agencies against the same defendants involving the same transactions". (2009, p. 440, em que há referência ao caso citado: "SEC v. First Financial Group of Texas, Inc. 659.F2d 660, 666 (5th Cir. 1980).

${ }^{617}$ Correspondente às mesmas condutas analisadas pelo Processo Administrativo Sancionador CVM n. SP2007/0119, embora ambos sob prismas distintos.

${ }^{618}$ Sentença da ação penal autuada sob o n. 0005123-26.2009.403.6181, distribuída à 6a Vara Especializada em Crimes Contra o Sistema Financeiro Nacional e Lavagem de Valores, na Seção Judiciária de São Paulo da Justiça Federal, proferida em 16 de fevereiro de 2011, disponível para acesso em 〈http://www.jfsp.jus.br/assets/Uploads/administrativo/NUCS/decisoes/2011/110221insidersadia.pdf)> acessada em 10dez2012.

${ }^{619}$ REsp 677.585/RS, Rel. Min. Luiz Fux, $1^{\mathrm{a}}$ Turma, j. 06.12.2005.
} 
danos, ambas decorrentes da mesma conduta) ${ }^{620}$ e também, um caso extremo ${ }^{621}$, no qual se concluiu que "a responsabilidade do prefeito pode ser repartida em quatro esferas ${ }^{622}$ : civil, administrativa, política e penal" e sob cujo ângulo "ressoa evidente que apenas um ato praticado pelo prefeito pode ensejar a instauração de mais de um processo e atingir mais de uma órbita de responsabilização do chefe do executivo municipal, com imposição de pena privativa de liberdade de direitos, obrigação de ressarcir ao erário, cassação de mandato e a inabilitação para o exercício dos direitos políticos, por exemplo”.

A produção de efeitos em mais de um segmento do ordenamento jurídico por uma ação ou omissão praticada no âmbito do mercado de valores mobiliários, e os tratamentos independentes entre os agentes públicos responsáveis pela tutela de cada um dos segmentos, é confirmada também pela doutrina. Nas palavras do Professor LEÃES (2004, p. 1.433), em estudo abordando o panorama sancionador do mercado financeiro e de capitais em sentido amplo:

\begin{abstract}
"Diversidade das sanções resulta a possibilidade da aplicação conjunta de [...] penalidades administrativas e penais, sem que ocorra o bis in idem, consoante afirmação pacífica entre os mestres. Nada impede o cúmulo de sanções administrativas, emanadas de diferentes órgãos estatais em função da polícia que exercem em áreas diferenciadas, levando em conta interesses jurídicos distintos. Da mesma forma, a falta administrativa pode ser de tal relevo que enfeixa crime ou contravenção penal, sujeitando o administrador à punição administrativa e à punição penal".
\end{abstract}

Outra consequência da divisão entre as esferas ocorre quando um investidor entende ser insuficiente a indenização a ele atribuída a título de medida reparadora, pactuada entre a CVM e determinado agente do mercado, em termo de compromisso. Pode, caso julgue adequado, pleitear em nome próprio montante complementar ao convencionado no acordo administrativo, a título de reparação civil, que em nada é

${ }^{620}$ RMS 21.114/BA, Rel. Min. Castro Meira, 2a Turma, j. 06.06.2006, em cujo voto condutor afirmou-se que "De fato, não se verifica aplicação de dupla penalidade, como quer fazer crer o ora recorrente, mesmo porque cuida-se de dois procedimentos diversos, no primeiro, a aplicação de multa na esfera administrativa, em favor do Fundo Estadual de Defesa do Consumidor, no segundo, na esfera judicial, transita ação de indenização por perdas e danos. Assim, não há que se falar em violação ao princípio do ne bis in idem, já que as esferas administrativa e judiciária são independentes, possibilitando a interposição simultânea de recurso administrativo e de ação de indenização por danos, como é o caso". Sem prejuízo da precisão da ideia plasmada no acórdão, seria possível tornar a decisão mais técnica caso o Ministro contrapusesse a esfera administrativa à civil, em substituição ao termo "esfera judicial" adotado, pois pode ser necessário que, em determinado caso, existam procedimentos judiciais relacionados à esfera civil e criminal, por exemplo.

${ }^{621}$ REsp 1.066.772/MS, Rel. Min. Benedito Gonçalves, $1^{\mathrm{a}}$ Turma, j. 25.08.2009.

${ }^{622}$ Naturalmente, existindo previsão no ordenamento jurídico a respeito de todas as normas, suas infrações e as consequências: "O código Penal define sua responsabilidade penal funcional de agente público. Enquanto que o Decreto-Lei n. 201/67 versa sua responsabilidade por delitos funcionais (art. $1^{\circ}$ ) e por infrações político-administrativas (art. $4^{\circ}$ ). Já a Lei n. 8.429/92 prevê sanções civis e políticas para os atos improbos. Sucede que, invariavelmente, algumas condutas encaixar-se-ão em mais de um dos diplomas citados, ou até mesmo nos três, e invadirão mais de uma espécie de responsabilização do prefeito, conforme for o caso". 
obstado $^{623}$ pela decisão da autoridade administrativa para celebração do instrumento alternativo em procedimento sancionador ${ }^{624}$.

Registre-se que, naturalmente, a análise do pedido e do caso como um todo pelo Judiciário tende a ser substancialmente facilitada quando existe uma decisão da Comissão atestando ou rechaçando a existência da infração administrativa, causadora do pedido de ressarcimento complementar ${ }^{625}$. Inexistindo julgamento administrativo, por conta da destinação dos processos sancionadores em que há termo de compromisso adimplido (enviado aos arquivos da Comissão, sem julgamento), caberá ao magistrado proferir a primeira decisão sobre o tema, não devendo ser influenciado, positiva ou negativa, pela celebração do termo de compromisso ${ }^{626}$.

A mesma dinâmica deve ser observada no contexto criminal. É possível que uma conduta, passível de responsabilização administrativa e penal venha a ser julgada no Judiciário sem que sequer seja decidida no âmbito administrativo, em decorrência de celebração de termo de compromisso com a CVM, ou que um acordo administrativo seja

\footnotetext{
623 "E sem nenhuma influência [do acordo administrativo] no penal e sem nenhuma influência no civil. Se é um termo de compromisso na CVM, paga-se multa [sic] e assim por diante. Só que aquela conduta gerou um prejuízo para um particular. Eu sou vítima de um insider, houve um termo de compromisso com a CVM, é evidente que eu tenho o direito de ser ressarcido pelos prejuízos que me foram causados. E se há um dano social que mereça a interferência do direito penal, é evidente que, mesmo com o termo de compromisso, desde que, com o respeito ao devido processo legal e o contraditório, haverá a possibilidade de condenação penal”. Declaração de Proença, p. 32 dos Cadernos Direito GV, Seminário 38, v. 7, n. 6, nov. 2010.

${ }^{624}$ Adicionalmente, sobre a relação e independência entre as esferas em que são produzidos efeitos na ocorrência de infrações às normas de mercado, cf. MANCUSO, R. de C. Ação civil pública para tutela dos interesses dos titulares de valores mobiliários e investidores do mercado - uma análise da Lei 7.913, de 07.12.1989. in Revista dos Tribunais, 650, de 1989, especificamente o item 3 (Contraste entre os ilícitos civis previstos na Lei 7.913/89 e os tipos penais na "lei do colarinho branco" (n. 7.492/86).

625 "Outra situação corriqueiramente se apresenta: no curso do processo administrativo [...] em que figure como interessado o autor ou o réu da ação judicial na qual se pretende a manifestação da autarquia na qualidade de 'amicus curiae', o Colegiado da CVM já apresentou manifestação conclusiva sobre referidos fatos. Nestes casos, em regra, encaminham-se ao Poder Judiciário as referidas decisões administrativas, bem como informações acerca de seu cumprimento". TANJI (2009, p. 109).

626 “[...] o efeito [da celebração do termo de compromisso com a CVM sobre as outras esferas] é psicológico, se for psicológico. Quer dizer, do ponto de vista técnico, não há qualquer tipo de relevância. Até porque, o termo de compromisso é justamente esse ajuste para não brigar e falar: 'Não quero mais saber do processo, vou me render às condições da CVM.' Mas não há qualquer tipo de culpa. Embora não haja uma assunção explícita de culpa, há sempre essa questão de que, implicitamente, ele estaria confessando. Na minha perspectiva, ou no caso concreto houve o termo de compromisso e isso não influenciou em nada a formulação da minha denúncia porque, enfim, analisei sob o aspecto penal. Agora, é diferente, por exemplo, de uma absolvição do âmbito administrativo, final do processo administrativo. Porque aí, a CVM se manifesta concretamente sob as provas obtidas, sobre a conduta." Declaração de Rodrigo de Grandis, p. 38 dos Cadernos Direito GV, Seminário 38, v. 7, n. 6, nov. 2010. Por outro lado, NAJJARIAN (declaração constante da p. 43 do mesmo registro) constata que há consequência prática, ainda que indevida, pela celebração de termos de acordo administrativo, sobre a persecução criminal, "O que eu vejo na esfera penal lá na Delegacia de Ilícitos Financeiros? [...] E eu sempre falo da independência das esferas, que ele pode continuar, enfim, deve continuar o inquérito. Mas é claro que enfraquece, isso é nítido".
} 
obtido em momento diferente de uma composição civil ou a suspensão de um processo criminal $^{627}$.

A impossibilidade de celebração de termos de compromisso pela CVM restringe-se à vedação proposta pelo próprio ordenamento ${ }^{628}$, aparentemente não comportando qualquer outra restrição. Em sentido contrário, pouco depois da adaptação dos acordos substitutivos ao mercado de valores mobiliário brasileiro, o Professor Verçosa (1998, p. 104) afirmou que

\begin{abstract}
"Evidentemente, a suspensão do processo administrativo não encontrará guarida nos casos em que forem apurados ilícitos criminais e a iniciativa da ação couber ao Ministério Público. Não se pode compreender que uma decisão administrativa no sentido da suspensão do procedimento administrativo viesse a impedir a apuração e a condenação penal. A investigação deve continuar para os fins administrativos e penais, levando-se, uma vez configurados os ilícitos, a uma condenação em ambas as esferas".
\end{abstract}

A resposta para as preocupações apresentadas residem, novamente, na independência das esferas e do destino que podem ter apurações promovidas independentemente, ainda que sua origem tenha sido a mesma conduta. Parece ser possível haver suspensão (e até arquivamento) do processo administrativo sancionador ainda antes da apresentação da denúncia para a instauração de ação penal e, uma vez recebida a denúncia, pode inclusive o compromitente no contexto administrativo ${ }^{629}$ ser condenado criminalmente, sem que tal sequência de eventos possibilite à CVM rever a celebração do acordo. A conclusão é que, efetivamente, decisão administrativa aprovando termo de compromisso em nada impede a apuração criminal, eis que situadas em esferas diferentes ${ }^{630}$.

Mesmo nos casos em que o Colegiado ou uma Superintendência da CVM não tenha decidido o mérito de caso, não pode ser afastada a participação da Comissão na qualidade de amiga da cúria ${ }^{631}$, nos termos do artigo 31 da Lei 6.385/76, conforme modificada pela Lei n. 6.616, de 16 de dezembro de 1978. Em tais casos, inexistindo decisão administrativa a ser apresentada, caberá à Procuradoria da Comissão apenas

\footnotetext{
${ }^{627}$ Exemplo citado no item 3.6.1.

${ }^{628}$ Analisada no item 3.6 supra.

629 Também não parece ser possível o desfazimento do acordo, nos casos de instauração de procedimento penal posterior à celebração dos termos, caso as obrigações pactuadas venham a ser adimplidas.

${ }^{630}$ Confiando na não aprovação do Projeto de Lei 1.851/2011, que poderia vir a modificar tal cenário.

631 "Creio, francamente, que os memoriais em que a autarquia age como amicus curiae representam, a longo prazo, uma das mais eficazes formas pelas quais a atividade didática da CVM se irá desenvolvendo no curso do tempo. Por isto mesmo, a apresentação didática dos conceitos como a orientação do órgão máximo da CVM tem, a meu ver, uma importância fundamental.” ARAGÃO (2006, p. 47). Para o tema, cf. DIDIER JR., F. A intervenção judicial do Conselho Administrativo de Defesa Econômica (art. 89 da Lei 8.884/1994) e da Comissão de Valores Mobiliários (art. 31 da Lei 6.385/1976). in Revista de Processo 115, 2004; e TAVARES, O. H. A CVM como 'amicus curiae'. in Revista dos Tribunais, 690/287, São Paulo: RT, 1993.
} 
esclarecer questões e auxiliar o juízo com os institutos do mercado de valores mobiliários, sem, contudo, induzir a decisão a ser tomada. 


\section{DESTINAÇÃO DOS RECURSOS ORIUNDOS DOS TERMOS DE COMPROMISSO}

O presente tópico trata da destinação dos recursos pagos em moeda corrente pelos administrados como condição para celebração do termo de compromisso, como tem sido a tendência nos últimos anos.

Como é possível depreender da análise do texto dos instrumentos de acordos assinados recentemente ${ }^{632}$, é consignado que o valor pago como condição para celebração do termo de compromisso será utilizado pela CVM "segundo seu exclusivo critério e conveniência". Adicionalmente, é explicitado em cláusulas específicas que os pagamentos devidos devem ser recolhidos por Guia de Recolhimento da União, identificando que a "Unidade Favorecida" é a Comissão.

É importante verificar a destinação do fluxo de pagamentos recebido pela Comissão para verificar se efetivamente há algum tipo de retorno para o mercado de valores mobiliários, ou se a "utilização" pela Comissão consiste em repasse à União Federal, sendo-lhe posteriormente "devolvida" uma parte pela via do orçamento regular para desempenho das atividades pela autarquia, consoante aprovação no Congresso Nacional.

Confirmada a última hipótese ${ }^{633}$, é possível entender que os recursos para custeio das atividades cotidianas da CVM dependem então, ao menos de certa medida, dos valores arrecadados com termos de compromisso e multas, o que é passível de críticas.

Há registro de termos de compromisso (antigos e recentes) condicionados à aquisição de ferramentas computacionais, custeio de pesquisas, patrocínio e viabilização de palestras, seminários e cursos, oferecimento de treinamentos ou investimentos, como livros, que diretamente asseguravam algum tipo de melhoria na estrutura da Comissão, aprimoramento das pessoas envolvidas no mercado, fossem participantes, agentes da autarquia responsáveis pela atividade de fiscalização do mercado de valores mobiliários ou o público em geral, vez que boa parte dos eventos era de acesso franqueado a qualquer interessado.

\footnotetext{
${ }^{632}$ São exemplos os acordos firmados nos seguintes casos: Processo Administrativo Sancionador CVM $\mathrm{n}^{\circ}$ RJ2011/8580, datado de 13 de julho de 2012; Processo Administrativo CVM n ${ }^{\circ}$ RJ2011/8755, datado de 18 de setembro de 2012; e Processo Administrativo Sancionador CVM nº RJ2012/3785, datado de 17 de outubro de 2012.

633 "De fato, os valores atribuídos à CVM nos termos de compromisso são recolhidos pelo compromitente mediante guia de recolhimento de receitas da União, e, assim, depositados na conta mantida pelo Tesouro Nacional. Não existe previsão, em lei, de constituição de fundo especialmente destinado a receber tais recursos, e, assim ,a empregá-los para a consecução de tal ou qual finalidade, à semelhança do Fundo de Direitos Difusos, no caso dos recursos provenientes de ações coletivas”. TANJI (2009 p. 102).
} 
É possível, em tais casos, imaginar situação de conflito de interesses ${ }^{634}$ entre o servidor público responsável por negociar ou aceitar propostas de termo de compromisso que representem melhorias diretas às suas próprias condições de trabalho. Exemplificativamente, a negociação de um termo considerando a premente necessidade de aquisição de determinado programa de computador, ou da realização de uma pesquisa por entidade especializada, cujos benefícios serão, naturalmente, revertidos à atividade desempenhada pela autarquia (indiretamente), mas cuja aprovação não representaria vantagem suficiente para a CVM aceitar as mesmas propostas, em condições ideais de estrutura para desenvolvimento das atividades do órgão ${ }^{635}$.

Parece ser a adoção de estrutura assemelhada ao Fundo de Defesa dos Direitos Difusos ("FDD") ${ }^{636}$ uma das alternativas viáveis, para que os valores pagos efetivamente traduzam-se em melhorias ao mercado, empregados em projetos aprovados por um Conselho Gestor ${ }^{637}$. Outra alternativa, menos eficiente, pois acarretaria diluição dos

\footnotetext{
${ }^{634}$ Além do risco de inobservância das normas de contratação com a administração pública, embora inexista registro conhecido de questionamentos tem tal sentido. "Não se reconhece, salvo disposição legal explícita, a obrigação de dar como cláusula de instrumento consensual na medida em que isto determinaria uma burla ao dever de licitar inscrito no art. 37, inc. XXI, da Constituição Federal. Em recente experiência dos termos de compromisso (TC) na Comissão de Valores Mobiliários, o ente regulador do mercado de capitais negociou a suspensão da aplicação de sanções administrativas aos agentes do mercado mediante o pagamento por estes de cursos internacionais aos funcionários da CVM ou, ainda, mediante a aquisição de certas obras para melhoria do acervo da biblioteca. Essas práticas vão de encontro ao dever de licitar na medida em que [...] não [...] [há] nenhuma hipótese de dispensa de licitação pela celebração de TC, estando, portanto, a aquisição de bens e serviços vinculada à realização de prévio procedimento licitatório no qual se garanta a igualdade perante os licitantes. Ademais, deve-se enfatizar o grande risco de captura do regulador engendrada pela referida prática, bem como o afastamento do instrumento consensual à sua função de satisfazer finalidades públicas, no caso, a saúde do mercado e valores mobiliários pela disponibilidade de informação, a 'afetação' do TC. Na qualidade de um instrumento regulatório, o acordo administrativo deve necessariamente induzir comportamentos do regulado, razão pela qual as cláusulas dos atos consensuais restringem-se, a princípio, a obrigações de fazer ou de não fazer". PALMA (2010, pp. 129-130).

${ }^{635}$ Quanto aos conflitos de interesse na celebração de termos de compromisso, cumpre referir ao Processo CVM SP 2011/0253, decidido pelo Colegiado em sua reunião de $1^{\circ}$ de novembro de 2011, o qual, entre outros temas, tratava de submissão à autarquia das mudanças estatutárias da BSM: "Multas e Termos de Compromisso: segundo a proposta, os recursos provenientes das multas aplicadas e termos de compromisso firmados deixariam de ser fontes de recursos para a BSM, e seriam revertidos, obrigatoriamente, para o patrimônio do Mecanismo de Recuperação de Prejuízos - MRP. A BSM justificou que a medida evitaria potenciais conflitos de interesse na atuação da BSM, na medida em que a apropriação desses recursos pode gerar uma perda de isenção na aplicação de sanções pecuniárias. O Colegiado indeferiu o pedido, acompanhando o entendimento da SMI, no sentido de que os recursos arrecadados com multas e termos de compromisso celebrados no âmbito da autorregulação devem ser revertidos, em sua totalidade, para aquelas atividades ou para a indenização de terceiros prejudicados. O Colegiado também acompanhou o entendimento da SMI no sentido de que a prevenção do alegado conflito de interesses entre a atividade sancionadora e o financiamento da atividade de autorregulação seria subproduto do monitoramento realizado pela CVM do resultado dos julgamentos da BSM e da avaliação da adequação das penas aplicadas. Ademais, a referida atividade e seu financiamento não estão isentos de conflitos de várias naturezas, mas cabe ao regulador, por meio dos mecanismos presentes na Instrução CVM 461/07, evitar que esses conflitos se concretizem".

${ }^{636}$ Criado pela Lei n. 7.347 , de 24 de julho de 1985 .

${ }^{637}$ Estabelecido pela Lei n. 9.008, de 21 de março de 1995.
} 
investimentos entre outras áreas da sociedade ${ }^{638}$, seria incluir a CVM, com as receitas auferidas com suas multas e termos de compromisso, no rol de entidades que colaboram com a arrecadação de quantias para o FDD, com indicação de representantes no Conselho Gestor.

Verifica-se que, nos casos em que há acordo celebrado pelo administrado simultaneamente com a CVM e o MPF, os valores seguem integral ${ }^{639}$ ou parcialmente $^{640} \mathrm{o}$ mesmo destino das multas e valores pagos no âmbito de acordos com autoridades concorrenciais $^{641}$ e condenações em ações civis públicas - o FDD $^{642}$.

Nos casos em que não há participação do Ministério Público, tutelando os direitos difusos, ainda que o particular proponha o direcionamento de recursos para o FDD, é impedido ${ }^{643}$ de concluir tal pagamento, por orientação da própria CVM, que entende inadequada tal destinação ${ }^{644}$.

\footnotetext{
${ }^{638}$ Parece pouco provável que a CVM se situasse na média de arrecadação de todas as outras áreas

${ }^{639}$ Como no caso do termo originado no Processo Administrativo CVM N. RJ2009/428, em que $\mathrm{R} \$ 200.000,00$ (duzentos mil reais) foram destinados ao FDDD

${ }^{640}$ Como no caso dos termos originados nos Processos Administrativos Sancionadores 10/2008 e 16/2008, em que $\mathrm{R} \$ 360.203,25$ (trezentos e sessenta mil, duzentos e três reais e vinte e cinco centavos) e $\mathrm{R} \$ 13.200 .000,00$ (treze milhões e duzentos mil reais), respectivamente, foram divididos entre a CVM e o FDDD

${ }^{641}$ Analisando o panorama dos recursos recolhidos nos acordos celebrados com a autoridade concorrencial, SAITO (2011, p. 28) explica que "recolhimento de contribuição pecuniária para o Fundo de Defesa dos Direitos Difusos se reverte em benefício para a sociedade como um todo. Isso porque, o Fundo tem como objetivo a reparação de danos causados ao meio ambiente, ao consumidor, a bens e direitos de valor artístico, estético, histórico turístico e paisagístico, em decorrência da prática de infrações à ordem econômica e a outros interesses difusos."

642 "o compromisso de cessação [do SBDC é] [...] condicionado a uma contribuição pecuniária ao Fundo de Direitos Difusos (FDD) - Criado pela Lei n. 7.347/85, com a finalidade de promover a reparação dos danos causados ao meio ambiente, ao consumidor, a bens e direitos de valor artístico, estético, histórico, turístico, paisagístico, por infração à ordem econômica e a outros interesses difusos e coletivos (CUEVA p. 289)

643 "Cumpre esclarecer que tal pagamento deverá ser realizado à CVM, por meio de Guia de Recolhimento da União (GRU). No âmbito dessa autarquia, recolhimentos ao Fundo de Defesa dos Direitos Difusos de que trata a Lei no 7.347/85 (Lei da Ação Civil Pública) têm sido adotados apenas em casos de TAC (Termos de Compromisso e de Ajustamento de Conduta), que é um procedimento capitaneado em conjunto pela CVM e pelo Ministério Público. A orientação adotada pelo Comitê é que os recursos dos Termos de Compromisso devem retornar ao mercado de valores mobiliários, por intermédio da autarquia reguladora e fiscalizadora desse mercado, dada a inexistência de fundo específico para o depósito desses recursos, por ausência de previsão na Lei $\mathrm{n}^{\circ}$ 6.385/76." (Parecer do Comitê em proposta de termo no Processo Administrativo Sancionador CVM RJ 2010/1380, em que o proponente ofereceu pagamento ao FDD).

644 “Contudo, o Comitê entende que se faz necessária a adequação da proposta, no que tange à destinação dos recursos, tendo em vista a inexistência de fundo nos moldes do fundo para reconstituição dos interesses transindividuais lesados, conforme previsto no art. 13 da Lei no 7.347/85 (Lei da Ação Civil Pública). Dessa forma, o Comitê sugere que o pagamento seja direcionado ao mercado de valores mobiliários por intermédio de seu órgão regulador, ao qual incumbe, dentre outros, assegurar o funcionamento eficiente e regular desse mercado (art. $4^{\circ}$ da Lei $\left.{ }^{\circ} 6.385 / 76\right)$ )."

(Parecer do Comitê de 17 de junho de 2006, em análise de proposta de acordo apresentada no Processo Administrativo Sancionador 01/2006)
} 


\section{CONCLUSÃO}

Considerando os alicerces legais e regulatórios existentes, a celebração de termos de compromisso entre a Comissão de Valores Mobiliários e agentes econômicos sob sua fiscalização constitui importante ferramenta à disposição desse órgão regulador e, em última análise, do mercado. Nos casos em que entender conveniente e oportuno, a Comissão está autorizada por lei a optar pelo procedimento alternativo, proporcionando maior eficiência na solução de atos contrários às normas que regem o mercado de valores mobiliários, pela flexibilização da habitual coercitividade dos processos sancionadores.

$\mathrm{O}$ incremento da eficiência, em decorrência da maior celeridade na cessação das condutas suspeitas praticadas pelos agentes - minimizando os danos causados e, principalmente, possibilitando o ressarcimento adequado a terceiros prejudicados (em tempo reduzido e sem que tenham que arcar com os custos de acesso ao Judiciário - por vezes desproporcionais aos benefícios esperados, inviabilizando tal medida) -, representa inegável vantagem em relação à atuação repressiva tradicional da Comissão, não consensual. Evita-se, por exemplo, que discussões sobre a ilicitude de determinada conduta consumam tempo e recursos da administração, ao assegurar a rápida interrupção das condutas consideradas lesivas ou prejudiciais ao mercado e a compensação dos danos.

$\mathrm{O}$ instrumento analisado, porém, não pode ser percebido pelos agentes como atenuação da atividade fiscalizatória e punitiva da CVM, como efetivamente não foi concebido para tal finalidade. O termo de compromisso, celebrado no contexto dos processos administrativos sancionadores da Comissão de Valores Mobiliários, não deve ser passível de ser calculado e considerado como custo previsível, permitindo a préquantificação da reparação de qualquer infração e eximindo o responsável das possíveis sanções. É inaceitável, pois, que os acordos substitutivos sejam considerados como despesa a possibilitar a realização de operação irregular, ou que condutas impróprias sejam praticadas reiteradamente. Ao contrário, qualquer acordo deve satisfazer de forma plena os objetivos da atividade repressiva, ainda que com consentimento dos potenciais infratores, para sinalizar claramente aos participantes do mercado - como parte essencial de sua função preventiva - que comportamentos em desacordo com as regras não serão tolerados.

A fim de alcançar êxito em tal escopo, a Comissão, especialmente por seu Colegiado (responsável por decidir a respeito da aceitação ou rejeição do quanto proposto pelos interessados), deve fazer cuidadosa verificação do conjunto dos "benefícios sociais 
líquidos"645 possíveis em cada caso, decorrentes do resultado de cada uma das duas opções à sua disposição - aceitar um acordo ou a conduzir o processo sancionador até o julgamento.

Além dos requisitos legais essenciais, sem os quais os acordos devem ser sumariamente vedados, há outros fatores, examinados neste trabalho, que podem ser úteis ao juízo de conveniência e oportunidade na sua celebração - tarefa nada simples a cargo da autoridade autárquica - e que devem ser considerados para a composição da melhor solução em cada caso.

A análise das bases normativas dos termos de compromisso celebrados entre a CVM e os administrados, realizada neste estudo, permite concluir que, não obstante possam ser constantemente aprimoradas - com fundamento na experiência acumulada pela entidade reguladora e na preocupação de resguardar seus princípios e objetivos - , tais bases são suficientes para propiciar sua adequada disciplina e aplicação, nos casos concretos. Cabe ao aplicador a sua correta utilização, para o que poderão ser úteis os elementos sistematizados neste trabalho.

${ }^{645}$ Termo extraído do Voto do Conselheiro do CADE Luis Fernando Schuartz, relator do Requerimento 08700.004221/2007-56, no contexto do Processo Administrativo 08012.011142/2006-79, p. 6. 


\section{BIBLIOGRAFIA}

ALVARENGA, M, I. de A. Adequação das funções legais da Comissão de Valores Mobiliários à realidade brasileira. Revista de Direito Mercantil, v. 105, p.144-158, jan/mar/1997.

ALVAREZ, A. B. A Comissão de Valores Mobiliários, instância reguladora independente? Direito, Estado e Sociedade, Rio de Janeiro, n.3, p.1-32, ago./dez. 1993.

AMARAL, P. A. S. S.A. - Como era, como ficou após a Lei n. 9.457/97. São Paulo: Oliveira Mendes, 1998.

AMENDOlarA, L. Processo Administrativo Sancionador no Âmbito do Mercado de Capitais. Rio de Janeiro: Forense, 2008.

ANGELINI, E. I mercati e gli strumenti finanziari di borsa: aspetti strutturali, normativi e funzionali del mercato mobiliare italiano. Torino: G. Giappichelli, 2006.

ARAGÃO, A. S. de. Agências Reguladoras e a Evolução do Direito Administrativo Econômico. 2. ed. Rio de Janeiro: Forense, 2003.

ARAGÃO, P. C. A CVM em juízo: limites e possibilidades. Revista de Direito Bancário e do Mercado de Capitais, São Paulo, v.9, n.34, p.38-49, out.-dez. 2006.

; SANTOS, P. R. A. dos. Notas sobre o consent decree. Estudo anexo ao

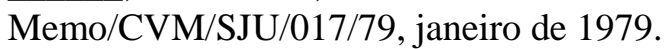

ASCARELli, T. Problemas das Sociedades Anônimas e Direito Comparado. 2. Ed. São Paulo: Saraiva, 1969.

ATALIBA, G. Inconstitucionalidade de punições permanentes. Revista de Direito Mercantil, Industrial, Econômico e Financeiro, São Paulo: RT, n. 95, p.15-25, 1994.

ÁVILA, Humberto Bergmann. Repensando o "Princípio da Supremacia do Interesse Público sobre o Particular”. Revista Trimestral de Direito Público, São Paulo: RT, v. 24. 1998.

. Teoria dos princípios - da definição à aplicação dos princípios jurídicos. 12. ed. São Paulo: Malheiros, 2012.

AZEVEDO, P. F. de. Voto apresentado no Requerimento n. 08700.004992/2007-43, referente ao Processo Administrativo 08012.011142/2006-79 (CADE). Brasília, 2008.

BACELLAR FILHO, R. F. Direito Administrativo e o novo Código Civil. Belo Horizonte: Fórum, 2007.

BAKER, N. A et al. The securities enforcement manual: tactics and strategies. Kirkpatrick \& Lockhart LLP, 2. ed., 2007.

BANDEIRA DE MELlO, O. A. Princípios Gerais de Direito Administrativo. Rio de Janeiro: Forense, v. 1, 1969.

BANDEIRA DE MELLO, C. A. Curso de Direito Administrativo. 25. ed. São Paulo: Malheiros, 2008. 
BARCELLONA, M. Mercato mobiliare e tutela del risparmio: L'intermediazione finanziaria e le responsabilità di banche e Consob. Quaderni di banca, borsa e titoli di credito, 31, Milano, Giuffrè, 2009.

BARROS, M. F. L. da R. O papel da legislação no desenvolvimento do mercado de capitais brasileiro: reflexões sobre a eficácia do sistema de regulação de valores mobiliários. São Paulo: 2004. Disponível em: <www.bmfbovespa.com.br/Pdf/MonografiaMariaF.pdf〉. Acesso em: 11 jul. 2011.

BARROSO, L. R. Temas de Direito Constitucional - Tomo II, Agências reguladoras. Constituição, Transformações do Estado e legitimidade democrática, Rio de Janeiro: Renovar, 2003.

Temas de Direito Constitucional - Tomo II, Banco Central e Receita Federal. Comunicação ao Ministério Público para fins penais. Obrigatoriedade da conclusão prévia do processo administrativo. Rio de Janeiro: Renovar, 2003.

BATISTA JÚNIOR, O. Transações Administrativas. São Paulo: Quartier Latin, 2007.

BINENBOJM, Gustavo. Uma Teoria do Direito Administrativo. Direitos Fundamentais, Democracia e Constitucionalização. Rio de Janeiro: Renovar, 2006.

BOCATER, M. I. do P. O exercício do poder de polícia e regulador da CVM - Aperfeiçoamentos recentes. In: MOSQUERA, R. Q. (coord.). Aspectos atuais do direito do mercado financeiro e de capitais. São Paulo: Dialética, 1999, p. 209-216.

BOCATER, M. I. do P.; CAMACHO, M. G. R. Capacidade legal da Comissão de Valores Mobiliários no Brasil para editar normas e regulamentos, e formas de fazê-las cumprir. Comissão de Valores Mobiliários, Rio de Janeiro, 1988.

BULGARELLI, W. Anteprojeto da CVM para a reforma da lei de sociedades por ações brasileiras. Revista de Direito Mercantil, Industrial, Econômico e Financeiro, São Paulo, v. 86, p. 58-70, 1992.

CABRAL, V. F. B. Os desafios da CVM. Revista de Direito Bancário e de Mercado de Capitais, São Paulo, n. 34, 2005.

CALABRÓ, L. F. A. Regulação e autorregulação do Mercado de Bolsa: Teoria Palco-Plateia. São Paulo: Almedina, 2011.

CANTIDIANO, L. L. O papel regulador da CVM. Revista de Direito Bancário e de Mercado de Capitais, São Paulo, v.8, n.27, p.38-41, jan.-mar, 2005.

Aspectos regulatórios do mercado de capitais. In: BACHA, E. L.; OLIVEIRA FILHO, L. C. de. Mercado de capitais e Crescimento econômico, lições internacionais, desafios brasileiros. Rio de Janeiro: Contra Capa, 2005.

. Regulação e desenvolvimento do mercado de capitais. Estudos de direito societário. Rio de Janeiro: Renovar, 1999.

A reforma da Lei das Sociedades por Ações. Revista Forense. Rio de Janeiro, v.340, p.127-144, out.-dez 1997. 
CARVALHO, C. A. C. de. Anotações sobre as agências reguladoras no direito estrangeiro: Europa, Estados Unidos e Argentina, Universidade Federal de Pernambuco, 2004.

CARVALHOSA, M.. Notícias sobre a reforma da lei de sociedades anônimas - projeto do deputado Emerson Kapaz. In MOSQUERA, R. Q. (coord.). Aspectos atuais do direito do mercado financeiro e de capitais. São Paulo: Dialética, v. 2, 2000, p. 177-185.

CARVALHOSA, M.; EIZIRIK, N. Nova Lei das S/A. São Paulo: Saraiva, 2002.

CESARINI, F.; GUALTIERI, P. La borsa. In: Farsi un'idea, 50, 3. ed. Agg, Bologna, Il Mulino, 2007.

CHEDIAK, J. F. P. A reforma do mercado de valores mobiliários. In: LOBO, J. (Coord.). Reforma da lei da lei das sociedades anônimas. Rio de Janeiro: Forense, 2002.

COMISSÃO de Valores Mobiliários, Regulação do mercado de valores mobiliários: fundamentos e princípios, Rio de Janeiro, 1979.

COMPARATO, F. K. O indispensável direito econômico. In: Ensaios e pareceres de Direito Empresarial. Rio de Janeiro: Forense, 1978.

COFFEE Jr., J. C.; SALE, H. A. Redesigning the SEC: Does the treasury have a better idea? University of Iowa Legal Studies Research Paper, n. 08-51, 2008.

CORBETT, D. A. The SEC's New Approach to Consent Decrees. New York Law Journal, August 27, 2003. (Artigo de Jornal igual à Revista)

CORREAA-LIMA, O. B. A reforma da lei das sociedades anônimas: Lei n. 9.457, de 5 de maio de 1997. Belo Horizonte: Del Rey, 1997.

COSTA, D. Solução de conflitos e o momento atual do mercado. Apresentação realizada no $6^{\circ}$ Seminário ANBID de Direito do Mercado de Capitais. Disponível em: <www.anbid.com.br/documentos_download/6sem_direito/Daniel_Costa.pdf $>$. Acesso em: 10 jul. 2011.

COSTA, L. C. A. Poder regulamentar das autarquias normatizadoras das atividades no mercado financeiro e de capitais. In MOSQUERA, R. Q. (coord.). Aspectos atuais do direito do mercado financeiro e de capitais. São Paulo: Dialética, v. 2, 2000, p. 121-140.

COSTI, R.. Il mercato mobiliare, 6. ed. Torino: G. Giappichelli, 2010.

COX, J. D.; THOMAS, R. S. SEC enforcement actions for financial fraud and private litigation: an empirical inquiry. Vanderbilt University Law School Law \& Economics Working Paper, n. 0308, 2003.

CUEVA, R. V. B. Termo de Compromisso no Processo Administrativo Sancionador do Banco Central: possibilidades e limites. In: OSÓRIO. F. M. (coord.). Direito Sancionador: Sistema Financeiro Nacional. Belo Horizonte: Fórum, 2007, p. 281-309.

DALLARI, A. A.; NOVIS, M. Processo sancionatório no âmbito da CVM: a pena de suspensão. In: Interesse Público. Belo Horizonte, v.10, n.47, p.13-36, jan.-fev. 2008. (Revista)

DANTAS, R. A confissão de culpa como requisito para celebração de termo de compromisso de cessação de prática em casos de cartel. In: Interesse Público, v. 13, n. 66, p.99-131, mar.-abr. 2011. 
DEL CARO, L.. À serviço do acionista. Revista Capital Aberto. Rio de Janeiro, n. Especial, p. 30, abr.2010.

DIAS, L. P. Regulação e auto-regulação no mercado de valores mobiliários. Dissertação apresentada na Faculdade de Direito do Largo São Francisco, 2005.

DINAMARCO, C. R. Instituições de direito processual civil. 3. ed. São Paulo: Malheiros, v. 4, 2009.

DUBEAUX, J. R. A Comissão de Valores Mobiliários e os principais instrumentos regulatórios do mercado de capitais brasileiro. Porto Alegre: Sérgio Fabris, 2006.

EIZIRIK, N. Reforma das S.A. \& do Mercado de Capitais. Rio de Janeiro: Renovar, 1998.

. A urgente reforma da Lei 6.386/76. Revista de Direito Mercantil, Industrial, Econômico e Financeiro, n. 98, abr.-jun. 1995.

. Nova lei do mercado de valores mobiliários. Revista da CVM, v. 4 n. 14out.-nov.-dez. 1986, p. 28-30.

. Reforma da Lei 6.385/76: uma nova moldura para a atuação da CVM. Revista da CVM, Rio de Janeiro, n.22-B, p.35-41, set.-dez.1994.

. Caracterização da operação fraudulenta no mercado de valores mobiliários. (parecer datado de setembro de 1988) In: Aspetos modernos do direito societário. Rio de Janeiro: Renovar, 1992, p. 179-198.

1977.

O papel do Estado na regulação do Mercado de Capitais. Rio de Janeiro: IBMEC,

. O colegiado da CVM e o CRSFN como juízes administrativos: reflexões e revisão. Revista de Direito Bancário e do Mercado de Capitais, São Paulo, v.9, n.34, p. 32-37, out.-dez. 2006.

EIZIRIK, N.; GAAL; A. B.; PARENTE, F.; HENRIQUES, M.. Mercado de capitais: regime jurídico. 2. ed. rev. e atual. Rio de Janeiro: Renovar, 2008.

ELIAS, S. N. V. Lavagem de dinheiro: criminalização, legislação e aplicação ao mercado de capitais. Monografia apresentada no Curso de Pós-Graduação em Regulação do Mercado de Capitais do Instituto de Economia da Universidade Federal do Rio de Janeiro - UFRJ, em 2005.

FARIA, C. B. L. de. O seguro D\&O e a proteção ao patrimônio dos administradores. São Paulo: Almedina, 2011.

FARIAS, T. Q. de. Termo de ajustamento de conduta e acesso à justiça. Revista Dialética de Direito Processual, São Paulo, n. 52, p. 116-124, jul. 2007.

FERRAZ, A. A. T. A Autorregulação do Mercado de Valores Mobiliários Brasileiro. Dissertação apresentada na Faculdade de Direito da Universidade Federal de Minas Gerais, Belo Horizonte, 2012.

FONSECA, J. B. L. Lei de proteção da concorrência: comentários à legislação antitruste. 2. ed. Rio de Janeiro: Forense, 2001.

GLAISYER, N.. The culture of commerce in England, 1660-1720. Woodbridge: Boydell \& Brewer, 2006. 
GOLDFARB, Z. A. SEC may require more details of wrongdoing to be disclosed in settlements. Disponível em: <http://www.washingtonpost.com/wpdyn/content/article/2010/03/31/AR2010033103674.html>. Acesso em 05 jul. 2011.

GRAU, E.R. Poder discricionario. Revista de Direito Público. São Paulo. v.23. n.93. p.34-40. jan./mar. 1990.

GRAU, E. R., FORGIONI, P. A. Compromisso de cessação e compromisso de desempenho na lei antitruste brasileira. in O Estado, a empresa e o contrato. São Paulo: Malheiros, 2005.

GRINOVER, A. P. Defesa da concorrência. Termo de compromisso de cessação de prática. Descumprimento. Preclusão. Multa. Revista IOB de Direito Administrativo, São Paulo, v.3, n.26, p.71-100, fev. 2008.

GUERREIRO, J. A. T. Sobre o poder disciplinar da CVM. Revista de Direito Mercantil, Industrial, Econômico e Financeiro, São Paulo, v. 43, 1981, p. 64-78.

Regulamento e seus pretextos. Revista Trimestral de Direito Público, São Paulo, n. 1, 1993, p. 303-308.

GUERREIRO, J. A. T.; TEIXEIRA, E. L. Das sociedades anônimas no direito brasileiro. São Paulo: Bushatsky, 1979.

HAULY, L. C. As Sociedades Anônimas e o Mercado de Capitais. Alterações decorrentes do Projeto de Lei $n^{\circ}$ 1.564, de 1996. Revista da CVM, Rio de Janeiro, p. 37-43, jan.-ago. 1996.

HÁFEZ, A. CVM mantém tendência de realizar termos de compromisso. Disponível em: <http://www.bmfbovespa.com.br/juridico/noticias-e-entrevistas/noticias/090526notA.asp>. Acesso em: 05 jul. 2011.

Risco Calculado - Pedidos pra realização de termos de compromisso aumentam. Disponível em: http://www.bmfbovespa.com.br/juridico/noticias-e-entrevistas/Noticias/Pedidospara-realizacao-de-Termos-de-Compromisso-aumentam.asp. Acesso em 05 mar. 2012.

HAZEN, T. L. The Law of Securities Regulation, Third Edition. West Publishing Co., Saint Paul, Minn., 1996.

HISTÓRIA da CVM: textos regulamentadores e documentos básicos da internacionalização. Revista de Direito Bancário e do Mercado de Capitais, São Paulo, v.9, n.34, p. 273-313, out.-dez. 2006.

JAKOBI, K. B. A atuação da CVM na regulação do mercado de capitais e na consagração do full disclosure, sob o enfoque da análise econômica do direito. Dissertação apresentada ao Programa de Pós-Graduação em Direito do Centro de Ciências Jurídicas e Sociais da Pontifícia Universidade Católica do Paraná, em 2011.

JOHNSON, D. L. SEC Settlement: agency self-interest or public interest. Fordham Journal of Corporate and Financial Law, v. XII, 2007, p. 627-683, 2007.

KANDIR, A. A Nova CVM e a Modernização da Lei das S/As. Revista da CVM, Rio de Janeiro, n. 35, p. 45-51, 2002. E em LOBO, J. (Coord.). Reforma da lei da lei das sociedades anônimas. Rio de Janeiro: Forense, 2002. 
KRUSSEWSKI, C. Direito administrativo sancionador: apontamentos gerais sobre as infrações administrativas e alguns aspectos de sua relação com o direito penal. Dissertação apresentada na Universidade Federal do Paraná em 2010.

LEÃES, L. G. P. de B. Mercado de capitais \& “insider trading”. São Paulo: Revista dos Tribunais, 1982.

O conceito de "security" no direito norte-americano e o conceito análogo no direito brasileiro. Revista de Direito Mercantil, Industrial, Econômico e Financeiro, São Paulo, n. 14, p. 41-60, 1974.

LEMOS, M. L. Reparação de danos no âmbito administrativo da Comissão de Valores Mobiliários - CVM. Monografia apresentada ao Curso de Pós-Graduação em Regulação do Mercado de Capitais do Instituto de Economia da Universidade Federal do Rio de Janeiro - UFRJ, em 2005.

LIMA, P. C. A. Sociedades por ações. Crítica - exegese. Rio de Janeiro: Edições Trabalhistas, 1977 (2 vols).

LOSS, L. O papel do governo na proteção dos investidores. Revista de Direito Mercantil, Industrial, Econômico e Financeiro, n. 58, São Paulo, 1985, p. 71-87.

MAIA, B.. Cálculo de risco: por que os cada vez mais milionários termos de compromisso se tornaram uma saída conveniente para a CVM e para os acusados. Revista Capital Aberto. n.091, p.28-31, mar.2011.

MAGALHÃES, C. A inserção institucional da agência regulatória do mercado de capitais. Revista de Direito Bancário e do Mercado de Capitais, São Paulo, v.9, n.34, p.95-256, out.-dez. 2006.

MAGLIANO FILHO, R. A importância do Conselho de Recursos do Sistema Financeiro Nacional (CRSFN) para o mercado de capitais. Revista de Direito Bancário e do Mercado de Capitais, São Paulo, v.8, n.30, p.323-6, out.-dez. 2005.

MARREY NETO, J. A. Processos administrativos na CVM: resolução CMN 2.785, de 18.10.2000. Revista de Direito Bancário, do Mercado de Capitais e da Arbitragem, São Paulo, v.3, n.10, p.44-9, out.-dez. 2000.

CVM: edital de audiência pública; processo administrativo sancionador. Revista de Direito Bancário, do Mercado de Capitais e da Arbitragem, São Paulo, v.5, n.18, p.28-40, out.-dez. 2002.

Projeto de resolução do CMN sobre processos/inquéritos administrativos da CVM. In MOSQUERA, R. Q. (coord.). Aspectos atuais do direito do mercado financeiro e de capitais. São Paulo: Dialética, v.2, 2000, p. 79-103.

MARTINS-COSTA, J. H. Princípio da confiança legítima e princípio da boa-fé objetiva. Termo de compromisso de cessação (TCC) ajustado com o Cade. Critérios da interpretação contratual: os "sistemas de referência extracontratuais" ("circunstância do caso") e sua função no quadro semântico da conduta devida. Princípio da unidade ou coerência hermenêutica e "usos do tráfego". Adimplemento contratual. (Parecer). Revista dos Tribunais, São Paulo, v.852, p.87-126, out. 2006.

MATTOS, César. O compromisso de cessação de práticas anticompetitivas no CADE: uma abordagem de teoria dos jogos. Revista do IBRAC, v. 4, n. 4, 1997. 
MELEGA, L. Comissão de Valores Mobiliários - Lei n.6.385 de 07.12.1976: alterações promovidas pela lei n. 9.457, de 05.05.1997. IOB-Repertório de Jurisprudencia: civil, processual, penal e comercial, São Paulo, n.17, p.345-342, set. 1997.

MELLO, P. C. de. Uma avaliação da regulação do mercado de capitais segundo a ótica de custos e benefícios. Revista da CVM, Rio de Janeiro, n.32, p.24-32, set. 2000.

MINK, G. F. C. Lavagem de Dinheiro. Monografia apresentada ao Curso de Pós-Graduação em Regulação do Mercado de Capitais do Instituto de Economia da Universidade Federal do Rio de Janeiro - UFRJ, em 2005.

MONIZ, P. R. G. A competência da Comissão de Valores Mobiliários. Revista Tributária e de Finanças Públicas, São Paulo, v.8, n.32, p.191-8, maio-jun. 2000.

MONTEIRO, M.. Insider trading: termos de compromisso. Revista RI - Relações com Investidores. São Paulo, n.157, p.62-64, out.2011.

MORAES, L. R. de. Considerações sobre o consent decree e sua aplicação no âmbito da disciplina do mercado de valores mobiliários. Revista de Direito Bancário e Mercado de Capitais, São Paulo, v. 4, 1999, p. 99-113.

. Prescrição da punibilidade das faltas administrativas sob a jurisdição da CVM. (Comissão de Valores Mobiliários). Revista de Direito Bancário e do Mercado de Capitais, São Paulo, Revista dos Tribunais, 1998, n. 2, p.98-112.

MOREIRA, E. B. Conselho Monetário Nacional, Banco Central e Comissão de Valores Mobiliários - considerações acerca da sua natureza jurídica em face das chamadas "agências administrativas". Revista de Direito Mercantil, Industrial, Econômico e Financeiro, São Paulo, v.42, n.131, p.136-150, jul.-set. 2003.

MOREIRA, R. G. Poder regulamentar da Comissão de Valores Mobiliários em face dos princípios da legalidade e separação de poderes. Revista de Direito Mercantil, Industrial, Econômico e Financeiro, São Paulo, v.42, n.131, p.122-43, jul.-set. 2003.

. Sociedades anônimas brasileiras e fechamento de capital. Curitiba: Juruá, 2006.

NOVELLI, J. M. N.. Instituições, políticas e ideias econômicas: o caso do Banco Central do Brasil. São Paulo: Annablume/Fapesp, 2001.

O'HARE, J. The use of the corporate monitor in SEC enforcement actions. Villanova University School of Law Working Paper Series, n. 08-103.

ORDINAMENTO e compiti istituzionali della Consob. Arzano: Simone, 2006.

OSÓRIO, F. M. Direito administrativo sancionador. 4. ed. São Paulo: RT, 2011.

PAHIN JR., F. A CVM aperta o cerco. Revista da Nova Bolsa, n. 10, p. 66-69, 2011.

PAULIN, L. A. Sanções pecuniárias aplicadas pela Comissão de Valores Mobiliários em função de seu poder de polícia. Momento em que os juros de mora podem ser reclamados do administrado. Análise do teor da Deliberação 501. Revista de Direito Bancário e do Mercado de Capitais, São Paulo, v.11, n.41, p. 154-176, jul.-set. 2008. 
PENTEADO, M. R. 20 anos da promulgação da Lei das S/A: anteprojetos e projeto visando sua reforma. Revista de Direito Mercantil, Industrial, Econômico e Financeiro, São Paulo, v. 105, p. 84-125, 1997.

PLÖGER, A. Os 30 anos da CVM: lutas e conquistas. Revista de Direito Bancário e do Mercado de Capitais, São Paulo, v.9, n.34, p.50-58, out.-dez. 2006.

PINHO, T. e Peixoto A. A reforma da lei das sociedades anônimas. Rio de Janeiro: Freitas Bastos, 2001.

PONTES DE MIRANDA, F. C. Tratado de Direito Privado. $3^{\text {a }}$ ed. Rio de Janeiro: Borsoi, 1970.

PRADO, V. M (coord.) Cadernos Direito GV v. 7 n. 6, Nov. 2010, Seminário 38.

Pricewaterhouse Coopers. Reforma da Lei das S.A. 2 ed. Série legis-empresa; 4) São Paulo: Altas, 2000.

FERRARI, Eduardo Reale. Termos de Compromisso de Cessação (TCC) e seus reflexos no crime de cartel. Boletim IBCCRIM, São Paulo, ano 16, n. 190, p. 9-10, set. 2008.

REQUIÃO, R. Considerações sobre o projeto de criação da Comissão de Valores Mobiliários. Revista de Direito Mercantil, Industrial, Econômico e Financeiro, São Paulo: RT, n. 20, p. 101109, 1975.

RIBEIRO, I. CVM e Judiciário: o efeito da incerteza jurídica nos investimentos em ações e a justiça especializada. 2006. Disponível em: 〈http://ssrn.com/abstract=976970〉. Acesso em: outubro2012

ROCHA, B. O poder normativo de órgãos da Administração: o caso da Comissão de Valores Mobiliários. Revista de Direito Mercantil, Industrial, Econômico e Financeiro, n. 64, p. 47-69, 1986.

ROCHA, Jean Paul Cabral Veiga da, As consequências institucionais do novo conceito de valor mobiliário: as competências do CMN, do Bacen e da CVM. Nacional. In: MOSQUERA, R. Q. (coord.). Aspectos atuais do direito do mercado financeiro e de capitais. São Paulo: Dialética, v. 2, 2000, p. 65-78.

ROSSI, M. C.; PRADO, V. M.; SILVEIRA, A. D. M. da; MARTINS, L.; PEREIRA, T. H. J. de A. Decisões da CVM em matéria societária no período de 2000 a 2006. Revista de Direito Bancário e do Mercado de Capitais, São Paulo, v.10, n.37, p.88-106, jul.-set. 2007.

SADDI, Jairo. Reformando o Conselho de Recursos do Sistema Financeiro Nacional. in MOSQUERA, R. Q. (coord.). Aspectos atuais do direito do mercado financeiro e de capitais. São Paulo: Dialética, v. 2, 2000, p. 49-63.

SAITO, Carolina. O termo de compromisso de cessação de prática e o reconhecimento de culpa. Revista do IBRAC, v. 20, p.13-49, 2911.

SAMPAIO, P. R. P. A utilização do termo de compromisso de cessação de prática no combate aos cartéis. Revista de Direito Administrativo, Rio de Janeiro, v. 249, p. 245-265, set. -dez. 2008.

SALLES, M. P. de A. Aspectos da competência do CMN e da CVM no mercado de valores mobiliários. Revista de Direito Mercantil, Industrial, Econômico e Financeiro, São Paulo: Malheiros, n. 108, p. 101-115, 1997. 
Os valores mobiliários na Lei das S/A. Revista de Direito Mercantil, Industrial, Econômico e Financeiro, São Paulo: Malheiros, n. 107, p. 123-128, 1997.

SAlOMÃO, C. Regulação da Atividade Econômica, Princípios e Fundamentos Jurídicos. São Paulo: Malheiros, 2001.

SANTOS, A. P. dos. Por que defender os termos de compromisso no mercado de capitais? Espaço Jurídico BM\&FBovespa, 2009. Disponível em: <www.bmfbovespa.com.br/juridico/noticias-eentrevistas/Noticias/100106NotA.asp>. Acesso em: 09 jul. 2011.

. Ajustes de conduta no âmbito da administração pública. Texto divulgado como roteiro à Oficina Temática n. 12 do II Congresso Brasileiro das Carreiras Jurídicas de Estado. Disponível em: 〈www.carreirasjuridicas.com.br/downloads/dia07oficina12texto0.pdf〉. Acesso em: 05 jul. 2011.

SANTOS, A. P. dos; OSÓRIO, F. M. Aproveitamento de atuação autorregulatória permite imposição adequada de penalidades. Espaço Jurídico BM\&FBovespa, 2009. Disponível em: <www.bmfbovespa.com.br/juridico/noticias-e-entrevistas/Noticias/090908NotB.asp>. Acesso em: 05 jul. 2011.

SANTOS, A. P. dos; WELLISCH, J. S. M; BARROS, J. E. G.. Notas sobre o poder normativo da comissão de valores mobiliários: CVM na atualidade. Revista de Direito Bancário e do Mercado de Capitais, São Paulo, v.9, n.34, p.68-84, out.-dez. 2006.

SARNO, P. M. A criação da CVM e a regulação sobre as companhais abertas. Revista de Direito Bancário e do Mercado de Capitais, São Paulo, v.9, n.34, p. 219-236, out.-dez. 2006.

SEABRA FAGUNDES, M. O. Contrôle dos Atos Administrativos pelo Poder Judiciário. 3 ed. Rio de Janeiro: Forense, v. 1, 1957.

SCHIRATO, V. R. A regulação brasileira do mercado de capitais: restrição da autonomia privada para a satisfação do interesse público. Revista de Direito Público da Economia, Belo Horizonte, n.16, p.183-220, out.-dez. 2006.

SILVA, P. F. D. da. Responsabilidade civil e administrativa na regulação do mercado de capitais. Revista de Direito Bancário e do Mercado de Capitais, São Paulo, v.9, n.34, p.237-256, out.-dez. 2006.

SILVEIRA, S. M. B. da. O instituto do termo de compromisso no sistema de regulação do mercado de capitais brasileiro. Dissertação apresentada na Pontifícia Universidade Católica de São Paulo, 2006.

SOUZA, L. M. Meios consensuais de solução de conflitos na supervisão do sistema financeiro: oportunidades de aprimoramento no processo administrativo sancionador do Banco Central do Brasil. Revista da Procuradoria-Geral do Banco Central, São Paulo, v. 4, n. 2, p. 99-137, dez. 2010.

SOUTO, Marcos Juruena Villela. Direito Administrativo Regulatório. 2. ed. Rio de Janeiro: Lumen Juris, 2005.

SZTAJN, R. O poder normativo da CVM em face da Constituição de 1988. In: A Nova Ordem Constitucional: Aspectos Polêmicos. Rio De Janeiro: Forense, 1990, p. 472-485.

Regulação e o mercado de valores mobiliários. Revista de Direito Mercantil, Industrial, Econômico e Financeiro, São Paulo, v. 135, p. 136-147, 2004. 
TÁCITO, C. Prescrição administrativa - Comissão de Valores mobiliários - inquérito administrativo. Revista de Direito Administrativo, Rio de Janeiro, n.196, p.285-93, abr./jun. 1994.

. Comissão de Valores Mobiliários, Poder Regulamentar. Temas de Direito Público, Rio de Janeiro, t. II, Editora Renovar, 1997.

TANJI, M. Mercado de capitais brasileiro e tutela coletiva de interesses. Dissertação de mestrado apresentada na Faculdade de Direito do Largo São Francisco, São Paulo, 2009.

TANURE, Fabrício. A responsabilidade administrativa no mercado de valores mobiliários. Monografia apresentada ao Instituto de Economia da UFRJ, em julho de 2005. Disponível em: <http://www.cvm.gov.br/port/public/publ/ie_ufrj_cvm/Fabricio_Duarte_Tanure.pdf >. Acesso em:

A nova função reguladora da Comissão de Valores Mobiliários, Agosto de 2003. Disponível em: < http://www.cvm.gov.br/port/public/publ/funcao.doc>. Acesso em: 13 set. 2012.

TRINDADE, M. Uma avaliação do regime repressivo: a experiência da Comissão de Valores Mobiliários. Apresentação realizada no $10^{\circ}$ Congresso Brasileiro de Fundos de Pensão. Curitiba, 2009.

Regulação do mercado de capitais no Brasil: evolução e desafios. Apresentação realizada no Seminário de Política Econômica do Departamento de Economia da Pontifícia Universidade Católica do Rio de Janeiro em 21 de maio de 2010.

O papel da CVM e o mercado de capitais no Brasil. In: SADDI, J. Fusões e Aquisições: aspectos jurídicos e econômicos, IOB, São Paulo, 2002, p. 297-329.

VERÇOSA, H. M. D. Notas sobre o regime jurídico das ofertas ao público de produtos, serviços e valores mobiliários no direito brasileiro - uma questão de complementação da proteção de consumidores e investidores. Revista de Direito Mercantil, Industrial, Econômico e Financeiro, São Paulo, v. 105, p. 74-83, 1997.

VERZOLA, A. C. O poder de polícia e a atividade sancionatória nos mercados financeiro e de capitais. Dissertação apresentada na Pontifícia Universidade Católica de São Paulo, 2008.

VILLELA SOUTO, M. J. Direito Administrativo Regulatório, 2. ed.. Rio de Janeiro: Lumen Juris, 2005.

WALD, A. A CVM e a evolução do mercado de capitais no Brasil. Revista Forense, Rio de Janeiro, v.98, n.363, p.3-16, set.-out. 2002.

Trinta anos da lei do mercado de valores mobiliários no Brasil. Revista de Direito Bancário e do Mercado de Capitais, São Paulo, v.9, n.34, p.5-9, out./dez. 2006.

A evolução do mercado de financeiro e de capitais (1998-2008). Revista de Direito Bancário e do Mercado de Capitais, São Paulo, n.41, p.11-13, 2008.

WELLISCH, J. S. M.; SANTOS, A. P. dos. O termo de compromisso no âmbito do mercado de valores mobiliários. Disponível em: <httphttp://www.iiede.org.br/uploads/paginas/file/termodecompromissonoambitoomercadodecapita is.pdf >. Acesso em: 08 dez. 2012. Publicada também em: Interesse público, v.11, n. 53, p. 137149 , jan./fev. de 2009. 
A evolução do processo administrativo sancionador no âmbito da Comissão de Valores Mobiliários. Revista de Direito Bancário e do Mercado de Capitais, São Paulo, v. 13, n. 48, p. 5380, abr.-jun. 2010.

YAZBEK, O. Regulação do Mercado Financeiro e de Capitais. Rio de Janeiro: Elsevier, 2009.

A regulamentação das bolsas de valores e das bolsas de mercadorias e futuros e as novas atribuições da comissão de valores mobiliários. Revista de Direito Bancário e do Mercado de Capitais, São Paulo, v. 9, n.34, p.198-218, out.-dez. 2006.

ZACLIS, L. Proteção coletiva dos investidores do mercado de capitais. São Paulo: RT, 2007.

YOKOI, Yuki. Receitas da CVM com termos de compromisso atingem recorde. Revista Capital Aberto. n.75, p.8, nov.2009. 